\title{
The anti-inflammatory potential of Adenosine - an experimental study with emphasis on ischemia- reperfusion injury
}

Citation for published version (APA):

Bouma, M. G. (1997). The anti-inflammatory potential of Adenosine - an experimental study with emphasis on ischemia-reperfusion injury. [Doctoral Thesis, Maastricht University]. Universitaire Pers Maastricht. https://doi.org/10.26481/dis.19971218mb

Document status and date:

Published: 01/01/1997

DOI:

10.26481/dis.19971218mb

Document Version:

Publisher's PDF, also known as Version of record

Please check the document version of this publication:

- A submitted manuscript is the version of the article upon submission and before peer-review. There can be important differences between the submitted version and the official published version of record.

People interested in the research are advised to contact the author for the final version of the publication, or visit the DOI to the publisher's website.

- The final author version and the galley proof are versions of the publication after peer review.

- The final published version features the final layout of the paper including the volume, issue and page numbers.

Link to publication

\footnotetext{
General rights rights.

- You may freely distribute the URL identifying the publication in the public portal. please follow below link for the End User Agreement:

www.umlib.nl/taverne-license

Take down policy

If you believe that this document breaches copyright please contact us at:

repository@maastrichtuniversity.nl

providing details and we will investigate your claim.
}

Copyright and moral rights for the publications made accessible in the public portal are retained by the authors and/or other copyright owners and it is a condition of accessing publications that users recognise and abide by the legal requirements associated with these

- Users may download and print one copy of any publication from the public portal for the purpose of private study or research.

- You may not further distribute the material or use it for any profit-making activity or commercial gain

If the publication is distributed under the terms of Article $25 \mathrm{fa}$ of the Dutch Copyright Act, indicated by the "Taverne" license above, 


\section{The Anti-Inflammatory Potential of Adenosine}

An experimental study with emphasis on ischemia-reperfusion injury

\section{PROEFSCHRIFT}

ter verkrijging van de graad van doctor

aan de Universiteit Maastricht,

op gezag van de Rector Magnificus, Prof. Mr. M.J. Cohen,

volgens het besluit van het College van Decanen,

in het openbaar te verdedigen

op donderdag 18 december 1997 om 16.00 uur

door

Maarten Godfried Bouma

geboren op 21 juni 1963

te Groningen

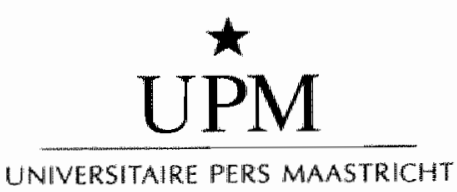




\section{Promotor}

Prof. Dr. G. Kootstra

\section{Co-promotores}

Dr. W.A. Buurman

Dr. F.A.J.M. van den Wildenberg

\section{Beoordelingscommissie}

Prof. Dr. J.P. van Hooff

(voorzitter)

Prof. Dr. J.F. Koster

(Erasmus Universiteit Rotterdam)

Prof. Dr. C.J. van der Linden

(Katholieke Universiteit Nijmegen)

Priv. Doz. Dr. I. Marzi

(Universität des Saarlandes, Duitsland)

Prof. Dr. L.H.E.H. Snoeckx

Prof. Dr. H.A.J. Struijker Boudier

ISBN: 9052782342

NUGl: 473

Druk: Datawyse, Maastricht

Layout: K. Scheele, 's-Hertogenbosch

The financial support for publication of this thesis from Bauerfeind Benelux, D.H. Heijne Stichting, Howmedica Nederland, Dr. Ir. J.H. van der Laar Stichting, Novartis Pharma, Ortomed, SNS-Bank Limburg and West Meditec is gratefully acknowledged. 
Aan mijn ouders 


\section{CONTENTS}

LIST OF ABBREVIATIONS

CHAPTER 1. Introduction and outline of the thesis.

CHAPTER 2. Adenosine inhibits neutrophil degranulation in activated human whole blood. Involvement of adenosine A2 and A3 receptors.

CH.APTER 3. Differential regulatory effects of adenosine on cytokine release by activated human monocytes.

ChAPTER 4. Adenosine inhibits cytokine release and expression of adhesion molecules by activated human endothelial cells.

CHAPTER 5. Hypoxia/reoxygenation of cultured human endothelium: effects on cellular activation and adenosine release.

CHAPTER 6. The adenosine kinase inhibitor GP515 attenuates leukocyteendothelial interactions in the liver after hemorrhagic shock and resuscitation in the rat.

CHAPTER 7. General discussion

CHAPTER 8. Summary / Samenvatting.

DANKWOORD

LIST OF PUBLICATIONS 


\section{LIST OF ABBREVIATIONS}

\begin{tabular}{|c|c|c|}
\hline ADA & $=$ & adenosine deaminase \\
\hline ADP & $=$ & adenosine diphosphate \\
\hline $\mathrm{AK}$ & $=$ & adenosine kinase \\
\hline AMP & $=$ & adenosine monophosphate \\
\hline ATP & $=$ & adenosine triphosphate \\
\hline $\mathrm{BCS}$ & $=$ & bovine calf serum \\
\hline BSA & $=$ & bovine serum albumin \\
\hline 2-CAdo & $=$ & 2-chloroadenosine \\
\hline cAMP & $=$ & cyclic AMP \\
\hline CPA & $=$ & $\mathrm{N}^{6}$-cyclopentyladenosine \\
\hline $\mathrm{dCF}$ & $=$ & 2'deoxycoformycin \\
\hline DMPX & $=$ & 3,7-dimethyl-1-propargylxanthine \\
\hline DPCPX & $=$ & 1,3-dipropyl-8-cyclopentylxanthine \\
\hline EHNA & $=$ & erythro-9-(2-hydroxy-3-nonyl)adenine \\
\hline ELISA & $=$ & enzyme-linked immunosorbent assay \\
\hline FMLP & $=$ & formyl-Met-Leu-Phe \\
\hline GP51.5 & $=$ & $\begin{array}{l}\text { 4-amino-1-(5-amino-5-deoxy-1-b-D-ribofuranosyl)-3-bromo- } \\
\text { pyrazolo[3,4-d]pyrimidine }\end{array}$ \\
\hline HUVEC & $=$ & human umbilical vein endothelial cells \\
\hline IB-MECA & $=$ & $\mathrm{N}^{6}$-(3-iodobenzyl)-adenosine- $5^{1}-\mathrm{N}$-methyluronamide \\
\hline $\mathrm{IC}_{50}$ & $=$ & $50 \%$ inhibitory concentration \\
\hline ICAM-1 & $=$ & intercellular adhesion molecule- 1 \\
\hline IL-1 & $=$ & interleukin-1 \\
\hline ]L-6 & $=$ & interleukin-6 \\
\hline IL-8 & $=$ & interleukin-8 \\
\hline LPS & $=$ & lipopolysaccharide \\
\hline $\mathrm{LTB}_{4}$ & $=$ & leukotriene $\mathrm{B}_{4}$ \\
\hline $\mathrm{mAb}$ & $=$ & monoclonal antibody \\
\hline $\mathrm{NECA}$ & $=$ & $5 \mathrm{~N}$-ethylcarboxamidoadenosine \\
\hline OFR & $=$ & oxygen free radical \\
\hline $\mathrm{PAF}$ & $=$ & platelet-activating factor \\
\hline PBS & $=$ & phosphate-buffered saline \\
\hline PECAM-1 & $=$ & pđatelet endothelial cell adhesion molecule-1 \\
\hline PMN & $=$ & polymorphonuclear leukocyte (neutrophil) \\
\hline PST & $=$ & $8(p$-sulphophenyl)theophylline \\
\hline TNF $\alpha$ & $=$ & tumor necrosis factor- $\alpha$ \\
\hline $\mathrm{TxA}_{2}$ & $=$ & thromboxane $\mathrm{A}_{2}$ \\
\hline VCAM-1 & $=$ & vascular cell adhesion molecule-1 \\
\hline $\mathrm{XAC}$ & $=$ & xanthine amine congener \\
\hline
\end{tabular}


CHAPTER 1

\section{Introduction and Outline of the Thesis}

Part of this chapter has been published as:

Bouma MG, Van den Wildenberg FAJM, Buurman WA

The anti-inflammatory potential of adenosine in ischemia-reperfusion injury: established and putative beneficial actions of a retaliatory metabolite Shock 8(5): 313-320, 1997 


\section{LIST OF ABBREVIATIONS}

\begin{tabular}{|c|c|c|}
\hline ADA & $=$ & adenosine deaminase \\
\hline ADP & $=$ & adenosine diphosphate \\
\hline $\mathrm{AK}$ & $=$ & adenosine kinase \\
\hline AMP & $=$ & adenosine monophosphate \\
\hline ATP & $=$ & adenosine triphosphate \\
\hline BCS & $=$ & bovine calf serum \\
\hline BSA & $=$ & bovine serum albumin \\
\hline 2-CAdo & $=$ & 2-chloroadenosine \\
\hline cAMP & $=$ & cyclic AMP \\
\hline CPA & $=$ & $N^{6}$-cyclopentyladenosine \\
\hline $\mathrm{dCF}$ & $=$ & 2'deoxycoformycin \\
\hline DMPX & $=$ & 3,7-dimethyl-1-propargylxanthine \\
\hline DPCPX & $=$ & 1,3-dipropyl-8-cyclopentylxanthine \\
\hline EHNA & $=$ & erythro-9-(2-hydroxy-3-nonyl)adenine \\
\hline ELISA & $=$ & enzyme-linked immunosorbent assay \\
\hline FMLP & $=$ & formyl-Met-Leu-Phe \\
\hline GP515 & $=$ & $\begin{array}{l}\text { 4-amino-1-(5-amino-5-deoxy-1-b-D-ribofuranosyl)-3-bromo- } \\
\text { pyrazolo [3,4-d]pyrimidine }\end{array}$ \\
\hline HUVEC & $=$ & human umbilical vein endothelial cells \\
\hline IB-MECA & $=$ & $\mathrm{N}^{6}$-(3-iodobenzyl)-adenosine-5'-N-methyluronamide \\
\hline $\mathrm{IC}_{50}$ & $=$ & $50 \%$ inhibitory concentration \\
\hline [CAM-1 & $=$ & intercellular adhesion molecule-1 \\
\hline IL- -1 & $=$ & interleukin-1 \\
\hline IL-6 & $=$ & interleukin-6 \\
\hline IL -8 & $=$ & interleukin-8 \\
\hline LPS & $=$ & lipopolysaccharide \\
\hline $\mathrm{L}_{4} \mathrm{~TB}_{4}$ & $=$ & leukotriene $\mathrm{B}_{4}$ \\
\hline $\mathrm{mAb}$ & $=$ & monoclonal antibody \\
\hline NECA & $=$ & 5'N-ethylcarboxamidoadenosine \\
\hline OFR & $=$ & oxygen free radical \\
\hline PAF & $=$ & platelet-activating factor \\
\hline PBS & $=$ & phosphate-buffered saline \\
\hline PECAM-1 & $=$ & platelet endothelial cell adhesion molecule-1 \\
\hline $\mathrm{PMN}$ & $=$ & polymorphonuclear leukocyte (neutrophil) \\
\hline PST & $=$ & $8(p-$ sulphophenyl)theophylline \\
\hline TNF $\alpha$ & $=$ & tumor necrosis factor- $\alpha$ \\
\hline $\mathrm{TxA}_{2}$ & $=$ & thromboxane $\mathrm{A}_{2}$ \\
\hline VCAM-1 & $=$ & vascular cell adhesion molecule- 1 \\
\hline $\mathrm{XAC}$ & $=$ & xanthine amine congener \\
\hline
\end{tabular}


CHAPTER 1

\section{Introduction and Outline of the Thesis}

Part of this chapter has been published as:

Bouma MG, Van den Wildenberg FAJM, Buurman WA

The anti-inflammatory potential of adenosine in ischemia-reperfusion injury: established and putative beneficial actions of a retaliatory metabolite Shock 8(5): 313-320, 1997 


\subsection{PATHOPHYSIOLOGY OF ISCHEMIA-REPERFUSION INJURY}

\subsubsection{DEFINTTION AND CLINICAL RELEVANCE}

Ischemia-reperfusion injury is defined as the tissue injury that occurs after restoration of temporarily interrupted blood supply to an organ or tissue. Whille ischemia or hypoperfusion per se can induce necrotic cell death and tissue damage, the extent being dependent on both the duration and the severity of ischemia, reperfusion causes a paradoxical aggravation of ischemic injury. Among the first to describe this paradox were Bulkley and Hutchins (1) in 1977, who reported on myocardial necrosis in areas of successful revascularization by coronary artery bypass graft surgery. In essence, the sequence of ischemia and subsequent reperfusion elicits a non-specific inflammatory process, that results in tissue damage considerably in excess of that induced by ischemia alone. The cellular, biochemical, and microcirculatory characteristics of this inflammatory response will be outlined below. Clinically, ischemia-reperfusion injury is a frequently encountered event, resulting in impaired organ function. Presumably the most often occurring clinical manifestations of reperfusion injury result from myocardial and cerebral infarction, and consequently much of the research work on this phenomenon has been performed in ischemia-reperfusion models of the heart and the brain. In surgical practice, ischemia-reperfusion may occur accidentally after trauma and acute arterial obstruction of the extremities or visceral organs. Similarly, the application and subsequent release of vascular cross clamps during major vascular or cardiopulmonary bypass surgery, or of tourniquets during limb surgery, will result in an ischemia-reperfusion event. In transplantation surgery, ischemia-reperfusion will occur by definition, and may contribute to primary graft dysfunction or even nonfunction. Moreover, the inflammatory reaction induced by ischemia and reperfusion of the graft may form the onset of rejection, and as such be detrimental to the host.

While ischemia-reperfusion of different single organs or tissues results in local injury, it may also lead to injury of remote organs with intact perfusion. Particularly, when the mass of ischemic tissue is large, such as the intestine or the lower extremities, non-cardiogenic pulmonary edema may occur. Already in 1969, Stallone et al. (2) reported the development of pathological alterations in the lung following ischemia-reperfusion of the lower extremities. Nowadays, these pulmonary changes are considered to be features of the adult respiratory distress syndrome (ARDS), and to be a part of multiple organ failure (MOF). Moreover, global ischemia resulting from hypovolemic or septic shock, can 
lead to a systemic inflammatory response syndrome (SIRS) culminating in multiple end-organ dysfunction with high mortality (3). While an initial massive ischemic insult may precipitate severe SIRS evolving directly into MOF, clinically the sequence of systemic priming of the inflammatory system, followed by a secondary activating event, seems to be more relevant $(3,4)$. In this so-called two-hit model, ischemia-reperfusion of the gut with subsequent bacterial translocation and release of neutrophil-activating substances, is thought to play a particularly important role $(5,6)$. Similarly, ischemiareperfusion of the lower limbs has been shown to increase gut permeability with subsequent systemic endotoxemia (7). Thus, ischemia-reperfusion may cause local organ injury as well as, depending on its extent, a systemic inflammatory reaction with remote organ injury. The pathophysiological characteristics of either لocal or distant injury are, however, remarkably singular, and will be discussed below.

\subsubsection{CENTRAL ROLE OF THE NEUTROPHIL}

There is general consensus about the involvement of neutrophils as the primary effector cells in ischemia-reperfusion-induced injury $(8,9)$. Early and convincing evidence for such a central role of neutrophils originated from various animal studies using different models of ischemia-reperfusion, where neutrophil depletion largely prevented reperfusion injury (10-18). Similarly, prevention of neutrophil adhesion to the vascular endothelium has been shown to markedly reduce reperfusion injury in many experimental models $(10,19$ 28). The observation that neutrophil depletion and prevention of neutrophil adherence are equally effective in attenuating reperfusion injury, suggests that neutrophil adherence is the rate-limiting step in neutrophil-mediated microvascular injury $(10,29)$. The enhanced adhesive interactions between neutrophils and endothelial cells and the resulting increased microvascular permeability are largely confined to the postcapillary venules of the microcirculation $(8,30,31)$.

There are several mechanisms by which neutrophils can induce postischemic microvascular damage. Neutrophils are part of the innate immune system and act as the first line of cellular defense against invading micro-organisms and other inflammatory stimuli under physiological conditions. Under pathological circumstances however, indiscriminate triggering of neutrophills may occur, resulting in a deleterious, self-destructive inflammatory process (32-34). In this respect, the accumulation of activated neutrophills in postischemic tissue hallmarks the inflammatory response to ischemia and reperfusion. The 
neutrophil's armamentarium to mediate acute inflammatory damage is generally divided into two systems, according to their localization within the cell. First, the plasma membrane-associated NADPH oxidase system generates the superoxide radical $\left(\mathrm{O}_{2}^{-}\right)$, from which the secondary toxic oxygen metabolites hydrogen peroxide $\left(\mathrm{H}_{2} \mathrm{O}_{2}\right)$ and hypochlorous acid $(\mathrm{HOCl})$ are formed. Second, the cytosolic system of intracellular granules contains bactericidal proteins and proteolytic enzymes, such as elastase, gelatinase and collagenase, which are released by degranulation. Both systems act in a cooperative and concerted manner, thereby enhancing the destructive potential of the neutrophil $(33,34)$. As a result, essential components of the extracellular matrix are degraded leading to increased microvascular permeability, the key histopathological feature of reperfusion injury. However, as stated above, a prerequisite for neutrophil-mediated microvascular and parenchymal reperfusion injury is the sequence of neutrophil chemotaxis and activation, adhesion to the postcapillary vascular endothelium, and subsequent transendothelial migration into postischemic tissue.

Another neutrophil-mediated mechanism of reperfusion injury is the obstruction of capillaries by activated neutrophils adhering to each other, a process termed aggregation. In vivo neutrophil aggregation may lead to the formation of occlusive plugs within the microcirculation (35). This plugging of capillaries contributes to the "no-reflow" phenomenon, that is a progressive cessation of blood flow which can be observed within minutes after reperfusion of ischemic tissue, and which can obviously exacerbate the ischemic injury (16, 36,37 ). Besides homotypic neutrophil aggregation, adherence of neutrophils to the postcapillary venular endothelium is a major factor contributing to postischemic capillary no-reflow $(38,39)$. Moreover, the ensuing vascular damage with endothelial cell edema and impaired ability to produce endothelial-derived vasodilating substances, such as nitric oxide (NO) and prostacyclin, plays an important role in the development of the no-reflow phenomenon (40-42).

In summary, neutrophils play a pivotal role in the pathogenesis of reperfusion injury, by contributing to the no-reflow phenomenon, and by adhesive interactions with endothelium of the postcapillary venules resulting in microvascular damage due to degranulation of hydrolytic enzymes and the production of toxic oxidants. The mechanisms involved in neutrophil recruitment into reperfused tissue are, however, very diverse and certainly not mutually exclusive. Nevertheless, a central pathogenetic mechanism, involving the generation of oxygen-derived free radicals (OFR), is generally considered to 
play a crucial role in the initiation of the various inflammatory cascades that eventually lead to neutrophil-mediated reperfusion injury.

\subsubsection{THE CONCEPT OF OXYGEN RADICAL-MEDIATED REPERFUSION INJURY}

The concept that OFR form a link between reperfusion injury and inflammation was introduced by Granger and McCord (43-45). Central to their theory of OFR-mediated reperfusion injury is the conversion of the enzyme xanthine dehydrogenase (XD) to xanthine oxidase $(\mathrm{XO})$ during ischemia (Figure 1.1), probably due to limited proteolysis as a result of activation of the cytosolic protease calpain $(45,46)$. Also during ischemia, massive catabolism of cellular ATP occurs, resulting in accumulation of its end-metabolite hypoxanthine.

Figure 1.1 Schematic diagram of neutrophil chemotaxis and activation, and subsequew endothelial adherence and transendothelial emigration in ischemia-reperfusion.

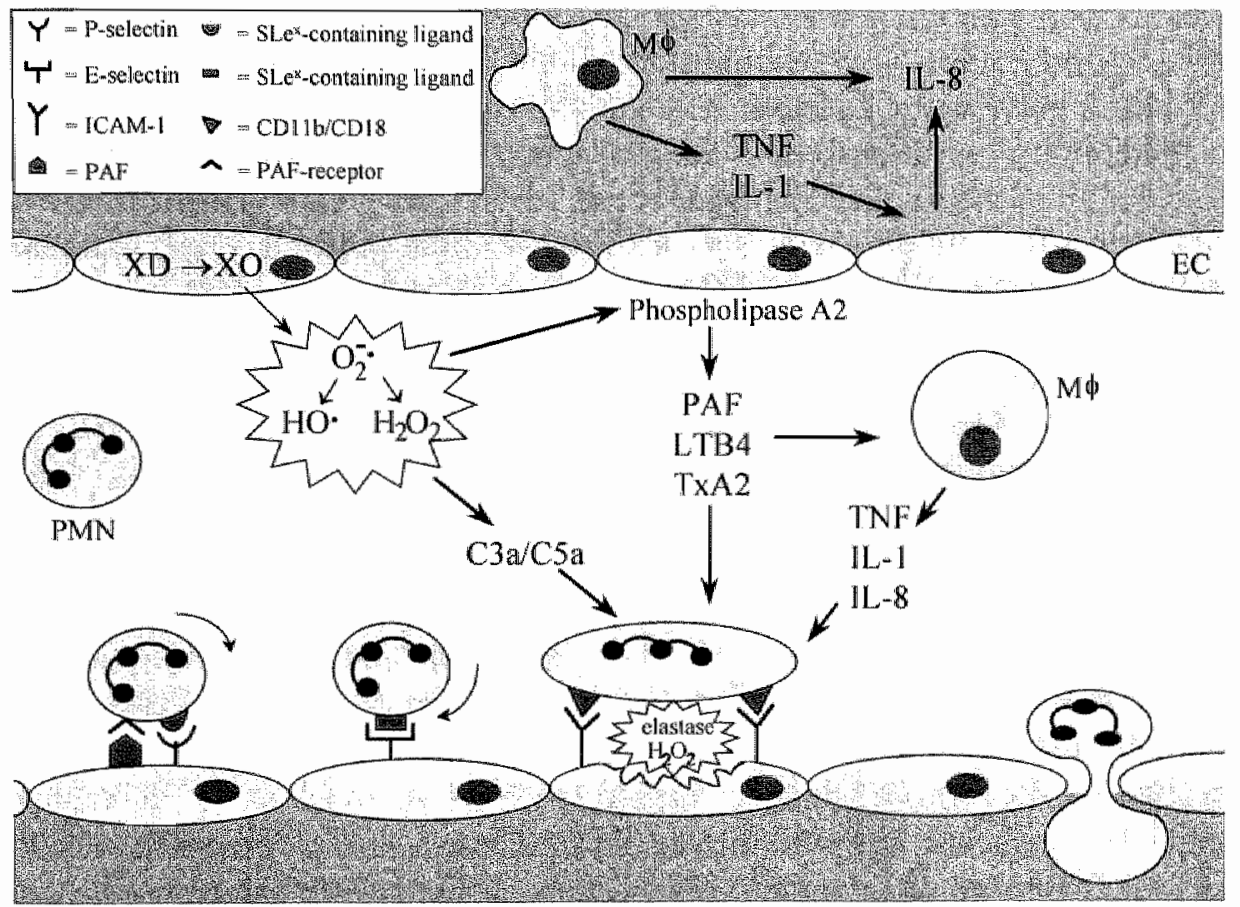

$\mathrm{EC}=$ endothelial cell; $\mathrm{M} \Phi=$ macrophage/monocyte; $\mathrm{SL} \mathrm{e}^{\mathrm{x}}=$ sialyl-Lewis $\mathrm{X}$ tetrasaccharide; $\mathrm{XD}=$ xanthine dehydrogenase; $\mathrm{XO}=$ xanthine oxidase. For other abbreviations, see text and List of Abbreviations. 
Upon reperfusion, when oxygen is re-introduced, XO converts hypoxanthine to xanthine with concomitant formation of large quantities of the superoxide anion $\left(\mathrm{O}_{2} \cdot\right)$ via univalent reduction of molecular oxygen. Additional toxic oxygen species, such as hydrogen peroxide $\left(\mathrm{H}_{2} \mathrm{O}_{2}\right)$ and the aggressive hydroxyl radical (HO), may subsequently be derived from superoxide by enzymatic and transition metal catalysis, respectively. Since the predominant localization of $\mathrm{XO}$ is within capillary endothelial cells (47), the vascular endothelium has been proposed as a central source of OFR generation during reperfusion $(48,49)$. This oxidative burst subsequently initiates a complex series of biochemical and microcirculatory events, that recruit neutrophils into reperfused tissue. In the course of these events, neutrophils become activated and generate OFR via the neutrophilic NADPH oxidase system, thus constituting a second important source of OFR production during reperfusion (10).

\section{No-reflow phenomenon}

The involvement of OFR in the initiation of the no-reflow phenomenon was demonstrated by Punch et al. (50) and by Suematsu and coworkers (51), who found that inhibition of XO activity by allopurinol or the competitive inhibitor BOF 4272 prevented no-reflow in skeletal muscle after 6 hours ischemia in the rat hind limb, and after 1 hour of hemorrhagic hypotension, respectively. In these studies endothelial damage occurred before leukocyte accumulation, suggesting the involvement of an endothelium-dependent XO-mediated mechanism in early no-reflow, rather than a neutrophil-dependent phenomenon. Nevertheless, after a latent period, neutrophils, activated either directly by OFR or by inflammatory mediators that may be released via OFR-mediated mechanisms, adhere to each other and to the vascular endothelium, thus contributing considerably to impaiment of reflow (35). Therefore, impairment of postischemic endothelium-mediated vasodilation may be both leukocytedependent as well as leukocyte-independent (52).

Another factor contributing to the no-reflow phenomenon may be the formation of microvascular thrombi as a result of platelet aggregation. Similarly to neutrophils, platelets are potential targets for the potent inflammatory mediators platelet-activating factor $(\mathrm{PAF})$ and thromboxane $\mathrm{A}_{2}\left(\operatorname{TxA}_{2}\right)$, which are known to be synthesized during reperfusion via an OFR-mediated mechanism (see below). Indeed, PAF-activated platelets display hyperaggregability and negatively affect coronary reflow during reperfusion (53). Furthermore, there is experimental evidence that in vitro hypoxia presumably by an oxidant-mediated mechanism $(54,55)$ - induces expression of tissue factor (TF), now accepted as the major initiator of coagulation in vivo 
$(56,57)$, which could contribute to the formation of occlusive platelet plugs, resulting in impairment of postischemic flow.

Microvascular spasm induced by vasoconstrictive mediators that are released in the setting of ischemia and reperfusion could also play a role in reduction of postischemic blood flow. For example, hypoxia can directly induce production and release of the vasoconstrictive autacoid endothelin-1 by endothelial cells (58), whereas products of OFR-mediated lipid peroxidation, such as leukotrienes, TxA $\mathrm{A}_{2}$ and PAF (see below), are also known to exert vasoconstrictive activity, particularly in the intestine and the lungs (59-61).

\section{Neutrophil chemotaxis and activation}

A relation between the production of OFR and neutrophil chemotaxis was elegantly demonstrated by Petrone et al. (62), who reported that superoxide activates a neutrophil chemotactic factor in human plasma, that was lipidderived and bound to serum albumin. They suggested that this factor was analogous or even identical to arachidonic acid oxidation products. Indeed, breakdown products of arachidonic acid exert potent neutrophil chemotactic activity and are produced in enhanced concentrations upon reperfusion (61, 6370). OFR induce peroxidation of membrane lipids, resulting in disturbance of intracellular calcium homeostasis and activation of phospholipase $A_{2}(71,72)$, a ubiquitous cellular membrane enzyme which catalyzes the formation of arachidonic acid and lysophospholipids from membrane phospholipids. Arachidonic acid may subsequently be metabolized through either the lipoxygenase or the cyclo-oxygenase pathway, yielding the eicosanoids leukotriene $\mathrm{B}_{4}\left(\mathrm{LTB}_{4}\right)$ and TxA $\mathrm{A}_{2}$, respectively. Alternatively, lysophospholipids may be remodeled into precursors of PAF. Both $\mathrm{LTB}_{4}$ and $T \times \mathrm{A}_{2}$, as well as PAF are well-recognized chemoattractants, and their role in neutrophil recruitment in reperfused tissues has been firmly established $(13,15,61,64-66,73-76)$. Moreover, these substances are potent neutrophil agonists, triggering neutrophil toxicity by inducing release of OFR and toxic proteases. Furthermore, neutrophil activation during chemotaxis by these agonists results in upregulation of $\beta_{2}$-integrin adhesion molecules, which are essential for subsequent neutrophil attachment to the endothelium (see below).

There is evidence to show that ischemia-reperfusion activates the alternative pathway of the complement cascade of plasma proteins (77-80), generating the chemotactic peptides C3a and C5a. Moreover, the classical complement cascade may also be activated during ischemia-reperfusion injury $(81,82)$. A1though the link between OFR production and activation of the complement system during ischemia-reperfusion is poorly characterized, it is conceivable that OFR- 
mediated loss of cell membrane integrity results in expression of neoepitopes, that are not recognized as self by the immune system, thus inducing complement activation (84). Similar to the lipid-derived mediators described above, C5a is also capable of potently triggering neutrophil respiratory burst activity and degranulation, as well as increasing neutrophil adhesiveness by upregulating the CD1 $1 \mathrm{~b} / \mathrm{CD} 18$ integrin $(78,85,86)$.

Several cytokines are known to be involved in neutrophil chemotaxis in inflammatory responses. Most notably, interleukin-8 (IL-8) has been identified as a very specific and potent neutrophil chemoattractant $(87,88)$. Furthermore, the macrophage-derived inflammatory cytokines interleukin-1 (IL-1) and tumor necrosis factor- $\alpha(\mathrm{TNF} \alpha)$ may have a direct chemotactic potency $(89,90)$, but mainly promote chemotactic migration of neutrophils by inducing release of the chemokine IL- 8 by endothelial cells (87) and fibroblasts (91). TNF $\alpha$ potently activates oxidant release by neutrophils adherent to endothelium, through a CD $11 \mathrm{~b} / \mathrm{CD} 18$-mediated signal (92), as well as via an endothelial cell-associated PAF-mediated mechanism (93). There is ample experimental and clinical evidence to support a role for these and other cytokines in the setting of ischemia-reperfusion, implicating the generation of OFR in cytokine production by mononuclear as well as endothelial cells $(94,95,98,99)$.

\section{Neutrophil adhesion and emigration}

Once neutrophils have been directed to the reperfused tissue along chemotactical concentration gradients, they are sequestered to the site of inflammation as a result of adherence to the vascular endothelial lining. This adhesive process is generally considered to occur in distinct sequential stages. Initially, neutrophils "roll" along the vessel wall due to transient and reversible intemittent adhesive interactions with the activated endothelial cell surface, and subsequently progress to a stationary state of "sticking" as a result of firm, continuous adhesive interactions with the endothelium.

Leukocyte rolling is due to low-affinity adhesive interactions with the endothelium, mediated by glycoproteins that belong to the selectin family of cell adhesion receptors. P-selectin and E-selectin on endothelial cells, and Lselectin on leukocytes, interact with ligands containing the tetrasaccharide sialyl-Lewis $\mathrm{X}\left(\mathrm{SLe}^{x}\right)$ or other sialylated, fucosylated structures, to mediate rolling. In particular, a role for endothelial P-selectin in ischemia-reperfusioninduced neutrophil adherence and subsequent reperfusion injury has been clearly demonstrated $(19,100-103)$. De novo expression of $\mathrm{P}$-selectin by endothellial cells in this setting may be induced directly by OFR $(104,105)$, as well as by substances that are released during reperfusion, such as C5a (106), 
TNF $\alpha$ (107), and IL-1 (108). It has been suggested that tethering of neutrophils by $\mathrm{P}$-selectin facilitates their activation by endothelial-associated PAF, which may be co-expressed with P-selectin in a juxtacrine manner (109). The involvement of oxidants in PAF-mediated endothelial cell-dependent neutrophil adhesion $(110,111)$ supports the relevance of regulated coexpression of $\mathrm{P}$ selectin and PAF to postischemic conditions. In several in vitro studies it has been hypothesized that OFR induce expression of endothelial E-selectin after anoxia-reoxygenation $(104,112)$, although others $(113,114)$ were unable to confirm this. As suggested by Seekamp et al. (115), participation of E-selectin in in vivo postischemic neutrophil-mediated tissue injury may be organ-specific and dependent on the production and release of cytokines, such as TNF $\alpha$ and IL-1, and may be confined to the lungs (115) and the heart (116). L-selectin, constitutively expressed on leukocytes, also seems to be required in the development of reperfusion injury $(115,117)$. The observation that treatment with soluble SLe $\mathrm{e}^{\mathrm{x}}$, which binds to all three selectins, effectively reduces both local and remote reperfusion injury in different experimental models, may underscore the similar, and possibly redundant, role of E-, P-, and L-selectin in postischemic neutrophil adherence $(19,115,118)$.

Leukocyte rolling evolves to a stationary state in which high-affinity adhesive interactions keep the leukocytes firmly attached to the endothelial surface. This stage is referred to as leukocyte sticking, and is mediated by leukocyte $\beta_{2}$ integrins, particularly Mac-1 (CD11b/CD18), binding to the endothelial ligand intercellular adhesion molecule-1 (ICAM-1). The importance of integrin-mediated adhesion in the development of the inflammatory response to ischemia-reperfusion has been firmly established $(10,20-24,110,119,121$ 125). Expression of the CDI1/CD18 integrins on neutrophils can be induced directly by oxidants (126), but also indirectly by other inflammatory mediators that are produced during reperfusion, such as $\mathrm{C}_{5} \mathrm{a}, \mathrm{LTB}_{4}$, and $\mathrm{PAF}(127,128)$. Upregulation of endothelial ICAM-I expression is dependent on the action of cytokines released during reperfusion, and may also be induced by oxidants $(129,130)$. As a result of firm adherence, a microenvironment at the neutrophilendothelial cell-cell interface is created, into which the activated neutrophils secrete their cytotoxic products, such as OFR and proteases, and cause endothelial injury, uninhibited by circulating anti-oxidants or anti-proteases (8). Eventually, neutrophils emigrate from the vasculature into the postischemic tissue by diapedesis between endothelial cells. A role for $B_{2}$-integrins, endothelial cell-associated PAF and the platelet endothelial cell adhesion molecule-1 (PECAM-1) in neutrophil transendothelial migration has been described (73, 131-133). Several of the chemoattractants that are released 
during reperfusion, such as $\mathrm{PAF}_{2} \mathrm{LTB}_{4}$ and IL-8, potently elicit leukocyte emigration $(132,134-136)$.

\subsection{THERAPEUTIC APPROACHES TO ISCHEMIA-REPERFUSION INJURY}

In view of the described complex pathogenetic mechanisms involved in local and systemic postischemic injury, theoretically there are multiple potential sites at which can be intervened to modulate the inflammatory response to ischemia and reperfusion. Indeed, a variety of approaches to the treatment of reperfusion injury exists, some of which have been implemented successfully in the experimental or clinical setting. In general, these therapeutic strategies are aimed at interfering at either the effector, the mediator or the tissue level of the inflammatory cascades elicited by ischemia and reperfusion (137). Although some of these strategies may have overlapping effects at more than one level, for reasons of clarity, they are discussed here separately.

\subsubsection{THERAPEUTIC STRATEGIES AT THE EFFECTOR LEVEL}

Inhibitors of OFR production, free radical scavengers and antioxidants Given the central role of XO-generated OFR and neutrophil-derived oxidants as effectors of peroxidative endothelial injury, agents that interfere with either the production or the harmful actions of OFR, have become important therapeutic tools to protect from reperfusion injury. Clearly, based on the significance of OFR in initiating the release of various inflammatory mediators and the expression of endothelial adhesion molecules during reperfusion, as described earlier, such agents may also be effective at the mediator and tissue level of intervention.

Allopurinol, a structural analogue of hypoxanthine, competitively inhibits the enzyme xanthine-oxidase, and thus reduces the production of the superoxide anion during ischemia-reperfusion, as was demonstrated experimentally (138, 139) and clinically (140). Similarly, iron-chelating agents, such as deferoxamine and ceruloplasmin, interfere with iron-mediated catalysis of the production of the hydroxyl radical (Haber-Weiss reaction), and have demonstrated beneficial effects in ischemia-reperfusion (139, 141-144).

Free radical scavengers are agents that interact with reactive oxygen species and render them harmless. Superoxide dismutase and catalase are endogenous enzymes that act in combination to scavenge superoxide and hydrogen peroxide, thus protecting against oxidant-induced tissue injury in vivo in 
ischemia-reperfusion syndromes as well as in other disease processes $(43,145$, 146). Changes in serum levels of these antioxidant enzymes have even been demonstrated to effectively predict the development of ARDS in septic patients (147). Other, non-enzymatic free radical scavengers include dimethylsulphoxide (DMSO), dimethylthiourea (DMTU), and mannitol, which neutralize the hydroxyl radical and have been used clinically for many years to prevent oxidant-mediated injury (148-152). Lazaroids (21-aminosteroids and 2methylaminochromans) are a relatively new class of compounds, designed and demonstrated to protect against tissue damage after trauma and ischemia by their ability to scavenge OFR and to inhibit superoxide-generating NADPH oxidase by neutrophils (153-155).

Antioxidants are agents that interrupt peroxidation, preventing the production of peroxides and terminating the chain reaction by which further free radicals are formed. Vitamin $E$ ( $\alpha$-tocopherol) is an endogenous antioxidant present within cell membranes and plasma lipoproteins, that cooperates with vitamin $\mathrm{C}$ (ascorbic acid) to minimize the consequences of lipid peroxidation $(156,157)$, and exogenous administration of vitamin $\mathrm{E}$ has been shown to reduce reperfusion injury $(158,159)$. Similarly, treatment with coenzyme Q10 (ubiquinol-10), another antioxidant present in biological membranes (160), attenuates OFR-mediated reperfusion injury (161). Glutathione (GSH) peroxidase is an endogenous antioxidant enzyme, located in the cytosolic and mitochondrial cellular compartments, that decomposes hydrogen peroxide to $\mathrm{H}_{2} \mathrm{O}$ at the expense of reducing equivalents from GSH (162). The antioxidant effect of the glutathione-glutathione peroxidase pathway can be effectively enhanced by replenishing intracellular GSH stores with the mucolytic agent $N$ acetylcysteine (Fluimucil ${ }^{\infty}$, Mucomyst ${ }^{\text {}}$ ), a precursor of GSH, which has been used successfully in several models of OFR-mediated disease processes, including ischemia-reperfusion (163-166).

\section{Specific inhibitors of neutrophil function}

As stated earlier, neutrophills are commonly regarded as the main effector cells of reperfusion injury, and therefore several therapeutic modalities have been designed that specifically prevent or inhibit neutrophil OFR production and proteolytic enzyme activity, or interfere with neutrophil adherence to the endothelium.

While the free radical scavengers and antioxidants mentioned above will non-specifically attenuate peroxidative injury caused by neutrophil-derived OFR, adenosine has been recognized as a specific physiological modulator of superoxide release by neutrophils (167). This neutrophil-inhibitory feature of 
adenosine will be discussed in more detail further on. Also, various calcium channel antagonists, including verapamil, can inhibit in vitro production of superoxide by stimulated neutrophils (168).

Several antiproteases inhibit neutrophil proteolytic enzyme activity, and thereby attenuate ischemia-reperfusion-induced neutrophil infiltration and increased microvascular permeability (169). Similarly, perfluorochemicals have been reported to suppress lyzozyme degranulation by activated neutrophils during myocardial reperfusion (170), and to prevent neutrophil-mediated injury of endothelial cells after anoxia (171).

A very effective means of specifically inhibiting neutrophil function in the setting of ischemia-reperfusion, is the use of monoclonal antibodies (mAbs) directed against the neutrophil CD1/b/CD18 (Mac-1) complex. Since the $\mathrm{CD} 11 \mathrm{~b} / \mathrm{CD} 18$ integrin is involved in neutrophil activation as well as adherence, administration of $\mathrm{MAbs}$ against either the CD1 $1 \mathrm{~b}$ subunit or the CD 18 subunit, has been shown to exert significant protective effects in many different in vivo models of reperfusion injury $(10,20-24,110,119-121)$.

\subsubsection{THERAPEUTIC STRATEGIES AT THE MEDIATOR LEVEL}

\section{Inhibitors of generation of arachidonic acid metabolites}

Activation of phospholipase $A_{2}$ is a proximal step in the generation of proinflammatory lipid mediators, and hence inhibition of this enzyme may prevent from reperfusion damage $(71,72,172)$, provided that the duration of the ischemic interval is limited, as suggested by Boros et al. (173). Inhibitors of the lipoxygenase and the cyclo-oxygenase pathway will reduce the generation of the chemoattractants $\mathrm{LTB}_{4}$ and $T x A_{2}$, respectively, and thereby prevent neutrophil activation and migration into reperfused tissue, as has been demonstrated in various experimental models $(13,63,66,68-70,136)$. However, as with phospholipase $A_{2}$ inhibitors, their efficacy may also depend on the length of the ischemic period (67). The generation of biologically active lewkotrienes from arachidonic acid can be suppressed by the incorporation of $n$ 3 polyunsaturated fatty acids, particularly eicosapentaenoic acid contained in fish oil. A high dietary intake of fish oil has been demonstrated experimentally to protect from reperfusion injury (174), and has been shown to correlate with a low mortality from myocardial infarction in large epidemiological studies (175, 176). 


\section{PAF receptor antagonists}

The significance of PAF in mediating neutrophil activation and adhesive interactions with the endothelium during reperfusion is underscored by the clearly demonstrated beneficial effects of PAF receptor antagonists in animal models of myocardial $(53,74,75)$, hepatic (76), renal (177), and intestinal (73) ischemia-reperfusion, as well as in kidney (178), liver (179), and heart-lung (180) transplantation models.

\section{Cytokine inhibitors}

During recent years, advances in immunological research have led to the development of mAbs against a wide variety of cytokines, which have been used to dissect the role of these mediators in the host inflammatory response. Because TNF $\alpha$ and IL-1 have been identified as proximal mediators of the inflammatory response to ischemia-reperfusion, the use of specific inhibitors that block or neutralize their biological effects may be an important site of therapeutic intervention.

Neutralization of circulating TNF $\alpha$, using anti-TNF $\alpha$ polyclonal antisera or $\mathrm{mAbs}$, has been shown to effectively attenuate both local and distant organ injury in different animal models of ischemia-reperfusion (181-184). While, clinically, the potential usefulness of mAbs to TNF $\alpha$ has been evaluated in the treatment of sepsis, with often disappointing results (185-187), their efficacy in human conditions of ischemia-reperfusion remains yet to be determined. As with TNF $\alpha$, the effects of circulating $\mathbb{I L - 1}$ in ischemia-reperfusion can also be neutralized with antibodies (188).

Alternatively, TNF $\alpha$ activity may be blocked by soluble TNF receptors that compete with cell surface receptors for TNF binding. Experimentally, administration of recombinant soluble TNF receptors has been an effective tool in preventing local and distant reperfusion injury (188, 189). Likewise, IL-1. receptor antagonists interfere with binding of IL-1 with its receptor, and have displayed protective effects in reperfusion injury of limbs (188) and brain (190), as well as in hemorrhagic shock and resuscitation (191).

While antagonism of the proximal inflammatory cytokines TNF $\alpha$ and IL-1 results in reduced leukocyte accumulation during reperfusion, neutrophil infiltration in postischemic tissue also can be prevented by administration of mAb or polyclonal antiserum against the chemotactic cytokine IL-8 $(192,193)$.

Transforming growth factor- $\beta$ (TGFB) is an essentially ubiquitous cytokine found in many immunocompetent cell types, that has been recognized as an endogenous immunosuppressive agent (194). Among the immunomodulatory actions that have been invoked as potential protective mechanisms of 
recombinant TGFB in reperfusion injury, are antagonism of TNF $\alpha$ effects and inhibition of TNF $\alpha$ release (195). In this context, it is also of interest that TGFB has been shown to induce release of the IL-1 receptor antagonist in vitro (196).

\subsubsection{THERAPEUTIC STRATEGIES AT THE TISSUE LEVEL}

\section{MAbs against endothelial adhesion molecules}

Where neutrophil accumulation in postischemic tissue is the hallmark of the inflammatory response to ischemia and reperfusion, and prevention of neutrophil-endothelial adhesion by blocking neutrophil adhesive receptors effectively blunts reperfusion injury $(10,20-28,121)$, antagonism of the endothelial counterreceptors will obviously provide similar protective effects. As described previously, neutrophil-endothelial interactions consist of three steps of sequential events, i.e., selectin-mediated rolling, tight adhesion mediated by neutrophil $\beta_{2}$-integrins interacting with their endothelial ligand ICAM-1, and transendothelial migration. Consequently, selectin-blocking approaches, using either $\mathrm{mAbs}$ against endothelial P- and E-selectin $(19,100$, $101,103,115,197,198)$, or SLe $e^{x}$-containing oligosaccharides $(19,115,118)$ have been successful in preventing from experimental reperfusion injury. Likewise, the use of mAbs against endothelial ICAM-1 has been shown to reduce neutrophil sequestration and concomitant injury in postischemic tissue $(119,120,122-125)$. Recently, results from a study by Murohara et al. (199) have indicated that blockade of PECAM-1 with a polyclonal Ab significantly attenuates myocardial ischemia-reperfusion injury in vivo, presumably by inhibiting transendothelial migration of neutrophils.

\subsection{PROTECTIVE ROLE OF ADENOSINE IN ISCHEMIA-REPERFUSION INJURY}

\subsubsection{ADENOSINE AND ADENOSINE RECEPTORS}

During ischemia, cellular energy stores, particularly of ATP, are depleted, resulting in failure of cellular homeostasis characterized by a loss of transmembrane sodium, potassium and calcium ion balances, leading to cell necrosis (44). As a consequence of ATP breakdown, its metabolites adenosine, inosine and hypoxanthine accumulate in the ischemic tissue. The major pathway by which adenosine is formed under these conditions is by dephosphorylation of AMP catalyzed by $5^{\prime}$-nucleotidase (200). While normally produced during 
physiological metabolic activity, adenosine can modulate a vast array of physiological processes in many mammalian systems. The numerous biological effects of adenosine on the central nervous, cardiovascular, respiratory, gastrointestinal, immune and metabolic system are mediated by activation of specific cell-surface adenosine receptors. Currently, four major subtypes of adenosine receptors have been classified on the basis of biochemical, functional and receptor-cloning studies (201). Activation of either A1, low-affinity A2a, high-affinity $\mathrm{A} 2 \mathrm{~b}$, or $\mathrm{A} 3$ receptors, modulates the activity of different second messenger systems, coupled to the various receptors. However, an extensive discussion of these second messengers is beyond the scope of this thesis, and excellent comprehensive reviews on this subject are available (200-203). Since adenosine has a short half-life in the circulation, it is generally assumed that it modulates cellular function by interacting with its receptors in an autocrine or paracrine manner (202). Whille adenosine functions as an important homeostatic mediator in the physiology of many organ systems, its role in pathophysiological conditions, particularly in ischemia-reperfusion where adenosine formation is directly linked to ATP catabolism, has received growing appreciation. Moreover, increased understanding of the beneficial actions of adenosine on metabolic, cardiovascular and inflammatory aspects of reperfusion injury, has led to the development of pharmacological agents that interfere with adenosine metabolism under these circumstances, as a potential therapeutic strategy to prevent or attenuate the deleterious consequences of ischemia and reperfusion.

\subsubsection{ADENOSINE AS A "RETALIATORY METABOLITE" IN ISCHEMIA- REPERFUSION}

Under conditions of cellular metabolic stress, when the cellular energy state is depleted, intracellular adenosine levels acutely increase due to breakdown of ATP, and adenosine is released from the cell. Particularly during ischemia, the level of extracellular adenosine available for activating adenosine receptors increases dramatically, as adenosine formation is directly linked to the massive ATP catabolism. Because the net effect of adenosine released under these circumstances is to reduce metabolic demand and to adjust the cellular energy supply, thus retaliating against the external stimulus, i.e. ischemia, that causes excessive ATP breakdown, Newby proposed the name "retaliatory metabolite" to describe adenosine (204). While in his original proposal of adenosine as a retaliatory metabolite attention was focused mainly on its beneficial metabolic and cardiovascular actions, the rapidly expanding knowledge of its very diverse 
anti-inflammatory effects, which may also counteract the deleterious consequences of ischemia-reperfusion, has added a new dimension to this concept. The beneficial "retaliatory" effects of adenosine in ischemiareperfusion, as summarized in Table 1.1, will be discussed below with special emphasis on its anti-inflammatory actions.

Table 1.I Established beneficial effects of adenosine in ischemia-reperfusion

References

\begin{tabular}{ll} 
Metabolic effects & \\
purine salvaging & $206-209$ \\
inhibition of lipolysis & 200,214 \\
$\begin{array}{l}\text { enhancement of glucose transport } \\
\text { stimulation of gluconeogenesis }\end{array}$ & 200,215 \\
& 200 \\
Cardiovascular effects & \\
$\quad \begin{array}{l}\text { vasodilation } \\
\text { inhibition of platelet aggregation }\end{array}$ & $200,213,240,241$ \\
$\begin{array}{l}\text { inhibition of vasoconstrictive mediators } \\
\text { negative inotropy and dromotropy }\end{array}$ & 203,242 \\
preconditioning & 63,217 \\
& 203 \\
Anti-inflammatory effects & $219-221$ \\
inhibition of neutrophil superoxide production & \\
inhibition of neutrophil adhesion & $167,217,230$ \\
\hline
\end{tabular}

\section{Metabolic actions}

Adenosine, as substrate for the regeneration of high-energy phosphates, may play a role in preservation of the nucleotide pool, which is depleted during ischemia. Indeed, purine salvaging with enhanced recovery of ATP has been invoked to explain the beneficial actions of exogenous adenosine in ischemiareperfusion (205-209). However, the importance of repletion of ATP in adenosine-mediated protection from reperfusion injury has been questioned $(210-212)$. Consistent with the retaliatory metabollite concept, adenosine acting via Al receptors inhibits catabolic hormone action, by antagonizing the effects of catecholamines in the heart and adipose tissue $(200,213)$. Furthermore, it plays a role in glucose metabolism by promoting the actions of the anabolic hormone insulin, and displaying insulin-like activity, such as inhibition of 
lipolysis, stimulation of gluconeogenesis, and facilitating glucose transport $(200,214-216)$, thus increasing energy supply.

\section{Cardiovascular actions}

The most prominent cardiovascular action of adenosine is its vasodilatory effect mediated by $\mathrm{A} 2 \mathrm{a}, \mathrm{A} 2 \mathrm{~b}$, and $\mathrm{A} 3$ receptors (201). By dilating pre-capillary sphincters and arteriolar resistance vessels, adenosine participates in the autoregulation of blood flow of organs, such as the heart, brain, gut, and skeletal muscle (203). As a result of vasodilation, the availability of substrate and oxygen during reperfusion is increased, and the no-reflow phenomenon is counteracted. Furthermore, via A2a receptor activation, adenosine inhibits platelet aggregation and adherence to the endothelium, thus preventing microvascular obstruction and no-reflow. Also, it may prevent microvascular spasm by reversing the effects of vasoconstrictive mediators, such as endothelin, leukotrienes, and PAF, that are released during reperfusion $(63$, 217). In the heart, adenosine exerts antiadrenergic, negative inotropic and dromotropic effects, and inhibits noradrenaline release from sympathetic nerve endings through activation of cardiac Al receptors, thereby reducing myocardial oxygen demand $(201,203,213,218)$.

A special form of adenosine-mediated protection against ischemic injury, is "preconditioning". Particularly in the myocardium, brief, intermittent episodes of ischemia, render cardiac tissue less sensitive to a subsequent sustained ischemic insult. This effect is thought to be mediated primarily by adenosine (219), acting via A1 receptors (220) as well as A3 receptors (221), and may occur through inhibition of adrenergic stimulation and of noradrenaline release, and activation of ATP-sensitive potassium channels with reduction of calcium overload $(220,222)$. However, the precise mechanisms involved in cardioprotective preconditioning and the relative importance of adenosine in this phenomenon have not been fully elucidated, and may vary between species (223). While the predictability of ischemic events during cardiopulmonary bypass surgery and transplantation makes the preconditioning phenomenon clinically relevant to protect the ischemic-reperfused myocardium, recently adenosine-mediated preconditioning has allso been shown to protect skeletal muscle from reperfusion injury (224), which could have therapeutic significance to other surgical fields, such as elective limb surgery.

\section{Anti-inflammatory actions}

One of the first clinical observations linking adenosine to the immune system was made in patients with a severe immunodeficiency disease, in whom an 
autosomal inheritable deficiency of the enzyme adenosine deaminase was found (225). As a result of the inability to catabolize adenosine, these subjects suffered from a failure to thrive, diarrhea, malabsorption and recurrent infections. The highly elevated plasma levels of adenosine in these patients resulted in impaired cellular immunity, due to a cytotoxic effect on $T$ lymphocytes. More recently however, it has been demonstrated that adenosine is in fact a physiological endogenous modulator of inflammatory processes, exerting either pro-inflammatory or anti-inflammatory effects, depending on the specific adenosine receptors activated. In particular, the work of Cronstein (226-229), and subsequently that of others, has identified adenosine as an important modulator of various neutrophil functions. Given the central role of neutrophils in the pathogenesis of reperfusion injury, the anti-inflammatory effects of adenosine on activated neutrophils have been consistently implicated in its protective role in ischemia-reperfusion. First, adenosine acting via A2 receptors potently inhibits superoxide anion generation by activated neutrophils, thereby limiting OFR-mediated injury of endothelial cells (167, $226,230,231$ ). Second, it can reduce neutrophil-mediated cellular injury by inhibiting neutrophil-endothelial adhesion, as a result of A2 receptor engagement on neutrophils (228). Several in vivo studies have demonstrated that adenosine inhibits ischemia-reperfusion induced adhesion (232-234), as well as adhesive interactions elicited by PAF $(134,235)$. It has been established that adenosine can interfere with both stages of the adhesion process, that is with selectin-mediated rolling $(232,236)$ as well as integrin-mediated sticking $(232,237-239)$ of neutrophils. Also, interference of adenosine with leukocyte emigration has been reported $(134,233,235)$. Thus, the anti-inflammatory effects of adenosine on activated neutrophil function have been firmly established and confirmed in in vivo ischemia-reperfusion models.

\subsection{OUTLINE OF THE THESIS}

From the previous introduction it can be concluded that several distinct immunocompetent cell types play a prominent role in the pathophysiology of the inflammatory response to ischemia and reperfusion. First, neutrophils have been undisputably identified as the primary effector cells of reperfusion injury. Second, cells of mononuclear lineage, such as monocytes and macrophages, are believed to be responsible for the excessive production and release of proinflammatory cytokines, as observed during ischemia-reperfusion. Third, the vascular endothelium is the center-stage where the inflammatory events take 
place, and is actively involved in the chemotaxis and activation of neutrophils and their guidance into target tissue.

As discussed previously, Cronstein was the first to recognize adenosine as an immunomodulatory agent, by describing its effects on superoxide generation by activated human neutrophils and demonstrating the involvement of specific adenosine receptors. Based on his observations, and given the ubiquitous presence of adenosine in the body, he proposed that adenosine functions as an important endogenous physiological anti-inflammatory molecule. Elaborating this concept further, we hypothesized that adenosine might modulate the inflammatory function of other immunocompetent cell types of human origin.

The main objective of this thesis, therefore, was to investigate whether adenosine affects relevant inflammatory features of the various different cell types involved in the host response to ischemia and reperfusion, and to determine the role of specific adenosine receptors in this context. Furthermore, the effects of agents that interfere with adenosine metabolism thereby enhancing endogenous adenosine release were evaluated in vitro as well as in vivo, in an attempt to assess the potential therapeutic relevance of such "adenosine-regulating" agents to inflammatory disorders, specifically ischemiareperfusion.

In Chapter 2 we study the effects of both exogenous and endogenous adenosine on the degranulation of activated human neutrophils, as determined by the release of neutrophil elastase, bactericidal/permeability-increasing protein and defensins, in an ex vivo whole blood model, and investigate the involvement of specific adenosine receptors.

In Chapter 3 the actions of adenosine on release of the pro-inflammatory cytokines TNF $\alpha, \mathrm{IL}-6$ and $\mathrm{IL}-8$ by activated human monocytes in vitro are determined and linked to specific adenosine receptors.

Similarly, in Chapter 4 the effects of exogenous and endogenous adenosine and receptor-specific adenosine analogues on activation of cultured human endothelium, as determined by the expression of the adhesion molecules Eselectin, ICAM-1 and vascular cell adhesion molecule-1 (VCAM-1), as well as the release of the cytokines $\mathbb{L}-6$ and $\llbracket L-8$, are evaluated.

Finally, the possible relevance of the adenosine-regulating agent GP515, an adenosine kinase inhibitor, to the treatment of ischemia-reperfusion-induced inflammation is assessed in an in vitro and an in vivo model of ischemiareperfusion in Chapter 5 and Chapter 6 , respectively. 


\section{ACKNOWLEDGEMENT}

The authors thank Mart-Jan Rongen M.D., and Anita Vreugdenhil for their help in preparing the illustration.

\section{REFERENCES}

1. Bulkley $\mathrm{BH}$, Hutchins GM. Myocardial consequences of coronary artery bypass graft surgery: the paradox of necrosis in areas of revascularization. Circulation 56: 906-913, 1977.

2. Stallone RJ, Lim RC, Blaisdell FW. Pathogenesis of the pulmonary changes following ischemia of the lower extremities. Ann Thorac Surg 7: 539-549, 1969.

3. Baue AE. MOF/MODS, SIRS: an update. Shock 6: S1-S5, 1996.

4. Moore FA, Sauaia A, Moore EE, Haenel JB, Burch JM, Lezotte DC. Postinjury multiple organ failure (MOF): a bimodal phenomenon. J Trauma 40: 501-510, 1996.

5. Mainous MR, Ertel W, Chaudry IH, Deitch EA. The gut: a cytokine-generating organ in systemic inflammation. Shock 4: 193-199, 1995.

6. Moore EE, Moore FA, Franciose RJ, Kim FJ, Biffl WL, Banerjee A. The postischemic gut serves as a priming bed for circulating neutrophils that provoke multiple organ failure. J Trauma 37: 881-887, 1994.

7. Corson RJ, Paterson IS, O'Dwyer ST, Rowland P, Kirkman E, Little RA, McCollum $\mathrm{CN}$. Lower limb ischaemia and reperfusion alters gut permeability. Eur J Vasc Surg 6: $158-163,1992$.

8. Welbourn CRB, Goldman G, Paterson IS, Valeri CR, Shepro D, Hechtman HB. Pathophysiology of ischaemia-reperfusion injury: central role of the neutrophil. $\mathrm{Br} J$ Surg 78: 651-655, 1991.

9. Simms HH. Polymorphonuclear leukocytes: their role as central cellular elements in shock pathogenesis. Shock 4: 225-231, 1995.

10. Hernandez LA, Grisham MB, Twohig B, Arfors KE, Harlan JM, Granger DN. Role of neutrophils in ischemia-reperfusion-induced microvascular injury. Am $J$ Physiol 253: H699-H703, 1987.

11. Romson JL, Hook BG, Kunkel SL, Abrams GD, Schork A, Lucchesi BR. Reduction of the extent of ischemic myocardial injury by neutrophil depletion in the dog. Circulation $67: 1016-1023,1983$.

12. Jaeschke $H$, Farhood A, Smith $C W$. Neutrophils contribute to ischemia/reperfusion injury in rat liver in vivo. FASEB J 4: 3355-3359, 1990.

13. Klausner $\mathrm{JM}_{4}$ Paterson IS, Valeri CR, Shepro D, Hechtman HB. Limb ischemia-induced increase in permeability is mediated by leukocytes and leukotrienes. Ann Surg 208: 755$760,1988$.

14. Klausner JM, Paterson IS, Goldman G, Kobzik L, Rodzen C, Lawrence R, Valeri CR, Shepro D, Hechtman HB. Postischemic renal injury is mediated by neutrophils and leukotrienes. Am J Physiol 256: F794-F802, 1989. 
15. Mullane KM, Salmon JA, Kraemer R. Leukocyte-derived metabolites of arachidonic acid in ischemia-induced myocardial injury. Federation Proc 46: 2422-2433, 1987.

16. Schmid-Schönbein GW, Engler RL. Gramulocytes as active participants in noute myocardial ischemia and infarction. Am J Cardiovasc Pathol 1: 15-30, 1987.

17. Smith SM, Holm-Rutili L, Perry MA, Grisham MB, Arfors KE, Granger DN, Kvietys PR. Role of neutrophils in hemorrhagic shock-induced gastric mucosal injury in the rat. Gastroenterology 93: 466-471, 1987.

18. Pearl JM, Drinkwater DC, Laks H, Stein DG, Capouya ER, Bhutr S. Leukocyte-depleted reperfusion of transplanted human hearts prevents ultrastructural evidence of reperfusion injury. J Surg Res 52: 298-308, 1992.

19. Weiser MR, Gibbs SAL, Valeri CR, Shepro D, Hechtman HB. Anti-selectin therapy modifies skeletal muscle ischemia and reperfusion injury. Shock 5: 402-407, 1996.

20. Vedder NB, Winn RK, Rice CL, Chi EY, Arfors K-E, Harlan JM. A monoclonal antibody to the adherence-promoting leukocyte glycoprotein, CD18, reduces organ injury and improves survival from hemorthagic shock and resuscitation in rabbits. $J \mathrm{Clin}$ Invest 81: 939-944, 1988.

21. Simpson PJ, Todd III RF, Fantone IC, Mickelson JK, Griffin JD, Lucchesi BR. Reduction of experimental canine myocardial reperfusion injury by a monoclonal antibody (anti-Mol, anti-CD I I b) that inhibits leukocyte adhesion. J Clin Imvesi $81: 624$.. $629,1988$.

22. Kubes $P$, Hunter $J$, Granger DN. Ischemia/reperfusion-induced feline intestinal. dysfunction: importance of granulocyte recruitment. Gastroenterology 103: 807-812, 1992.

23. Gomoll AW, Lekich RF, Grove RI. Efficacy of a monoclonal antibody (MoAb 60.3) in reducing myocardial injury resulting from ischenia/reperfusion in the ferret. $J$ Cardiovasc Pharmacol 17:873-878, 1991.

24. Ma X-L, Tsao PS, Lefer AM. Antibody to CD18 exerts endothelial and cardiac protective effects in myocardial ischemia and reperfusion. J Clin Invest 88 : 1237-1243, 1991.

25. Kurtel H, Tso P, Granger DN. Granulocyte accumulation in postischemic intestine: role of leukocyte adhesion glycoprotein CD11/CD18. Am I Physiol 262: G878-G882, 1992.

26. Welbourn R, Goldman G, Kobzik L, Paterson IS, Valeri CR, Shepro D, Hechtman HB. Role of neutrophil adherence receptors (CD18) in lung permeability following lower torso ischemia. Circ Res 71: 82-86, 1992.

27. Vedder NB, Winn RK, Rice CL, Chi EY, Arfors K-E, Harlan JM. Inhibition of leukocyte adherence by anti-CD 18 monoclonal antibody attenuates reperfusion injury in the rabbit ear. Proc Natl Acad SCi USA 87: 2643-2646, 1990.

28. Petrasek PF, Liauw $\mathrm{S}$, Romaschin $\mathrm{AD}$, Walker PM. Salvage of postischemic skeletal muscle by monoclonal antibody blockade of neutrophil adhesion molecule CD $18 . J \mathrm{surg}$ Res 56:5-12,1994.

29. Granger DN, Benoit JN, Suzuki M, Grisham MB. Leukocyte adherence to venular endothelium during ischenia-reperfusion. Am J Physiol 257: G683-G688, 1989.

30. Bienvenu K, Granger DN. Leukocyte adhesion in ischemia/reperfusion. Blood Cells 19: 279-289, 1993.

31. Schmid-Schönbein GW, Usami S, Skalak R, Chien S. The interaction of leukocytes and erythrocytes in capillary and postcapillary vessels. Microvasc Res 19: 45-70, 1980. 
32. Ahned $\mathrm{N}$, Christou $\mathrm{N}$. Systemic inflammatory response syndrome: interactions between immune cells and the endothelium. Shock 6: S39-S42, 1996.

33. Weiss S. T. Tisstue destruction by neutrophils. $N$ Eng J Med 320: 365-376, 1989.

34. Henson PM, Johniston Jr. RB. Tissue injury in inflammation. Oxidants, proteinases, and cationic proteins. J Clin Invest 79: 669-674, 1987.

35. Rochon YP, Frojmovic MM. A model for the recruitment of neutrophils at sites of inflammation. Physiological relevance of in vivo neutrophil aggregation. Med Hypotheses 38: 132-138, 1992.

36. Engler RE, Schmid-Sehönbein GW, Pavelec RS. Leukocyte capillary plugging in myocardial ischemia and reperfusion in the dog. Am of Pathol 111: 98-111, 1983.

37. Schmid-Schönbein GW. Capillary plugging by granulocytes and the no-reflow phenomenon in the microcirculation. Federation Proc 46: 2397-2401, 1987.

38. Jerome SN, Doré M, Paulson JC, Smith CW, Korthuis RJ. P-selectin and ICAM-1dependent adherence reactions: role in the genesis of postichemic no-reflow. $A m J$ Physiol 266: H1316-H1321, 1994.

39. Jerome SN, Akimitsu T, Korthuis RJ. Leukocyte adhesion, edema, and development of postischemic capillary no-reflow. Am J Physiol 267: H1329-H1336, 1994.

40. Hashimoto $\mathrm{K}$, Pearson PJ, Schaff HV, Cartier R. Endothelial cell dysfunction after ischemic arrest and reperfusion: a possible mechanism of myocardial injury during reflow. I Thorac Cardiowasc Surg 102: 688-694, 1991.

41. Mazzoni $\mathrm{MC}$, Borgström $P$, Intaglietta $M$, Arfors $K-E$. Capillary narrowing in hemorrhagic shock is rectified by hyperosmotic saline-dextran reinfusion. Circ Shock 31: 407-418, 1990.

42. Lefer AM, Tsao PS, Lefer DJ, Ma X-L. Role of endothelial cell dysfunction in the pathogenesis of reperfusion injury after myocardial ischemia. FASEB $J 5$ : 2029-2034, 1991.

43. Granger DN, Rutili $G_{*}$ McCord JM. Superoxide radicals in feline intestinal ischemia. Gastroenterology 81:22-29, 1981.

44. McCord JM. Oxygen-derived free radicals in post-ischemic tissue injury. $N$ Eng $J$ Med 312: 159-163, 1985 .

45. McCord JM. Oxygen-derived radicals: a link between reperfusion injury and inflammation. Federation Proc 46: 2402-2406, 1987.

46. Bindolini A, Cavallini L, Rigobello MP, Coassin M, Dilisa F. Modification of the xanthine-converting enzyme of perfused rat heart during ischemia and oxidative stress. Free Rad Biol Med 4: 163-167, 1988.

47. Jarasch E-D, Grund C, Bruder G, Heid HW, Keenan TW, Franke WW. Localization of xanthine oxidase in mammary-gland epithelium and capillary endothelium. Cell 25: 6782, 1981 .

48. Ratych RE, Chuknyiska RS, Bulkley GB. The primary localization of free radicall generation after anoxia/reoxygenation in isolated endothelial cells. Surgery 102: 122$131,1987$.

49. Zweier JL, Kuppusamy P, Lutty GA. Measurement of endothelial cell free radical generation: evidence for a central mechanism of free radical injury in postischemic tissues. Proc Natl Acad Sci USA 85: 4046-4050, 1988.

50. Punch J, Rees $\mathbb{R}$, Cashmer B, Wilkins E, Smith DJ, Till GO. Xanthine oxidase: its role in the no-reflow phenomenon. Surgery 111: 169-176, 1992. 
51. Suematsu M, DeLano FA, Poole D, Engler RL, Miyasaka M, Zweifach BW, SchmidSchönbein GW. Spatial and temporal correlation between leukocyte behavior and cell injury in postischemic rat skeletal muscle microcirculation. Lab Invest 70: 684-695. 1994.

52. Lefer AM, Aoki N. Leukocyte-dependent and leukocyte-independent mechanisms of impaiment of endothelium-mediated vasodilation. Blood Vessels 27: 162-168, 1990.

53. Ko W, Lang D, Hawes AS, Zelano JA, Isom OW, Krieger KH. Platelet-activating factor antagonism attenuates platelet and neutrophil activation and reduces myocardial injury during coronary reperfusion. J Surg Res 55: 504-515, 1993.

54. Crutchley DJ, Que BG. Copper-induced tissue factor expression in human monocytic THP-1 cells and its inhibition by antioxidants. Cinculation 92:238-243, 1995 .

55. Golino $\mathrm{P}$, Ragni M, Cirillo P, Avvedimento VE, Feliciello A, Esposito $\mathrm{N}$, Scognamiglio A. Trimarco B, laccariono $\mathrm{G}_{1}$ Condorelli M, Chiariello M, Ambrosio G. Effects of tissue factor induced by oxygen free radicals on coronary flow during reperfusion. Not $\mathrm{Med} 2$ : $35-40,1996$.

56. Gertler TP, Weibe DA, Ocasio VH, Abbott WM. Hypoxia induces procoagulant activity in cultured human venous endothelium. J Vasc Surg 13: 428-433, 1991.

57. Camerer $\mathrm{E}$, Kolsto A-B, Prydz H. Cell biology of tissue factor, the principal mediator of blood coagulation. Thromb Res 81: 1-41, 1996.

58. Battistini B, Forget MA, Laight D. Potential roles for endothelins in systemic inflammatory response syndrome with a particular relationship to cytokines. Shock 5 : $167-183,1996$.

59. Hsueh W, Gonzalez-Crussi F, Arroyave JL. Sequential release of leukotrienes and norepinephrine in rat bowel after platelet-activating factor: a mechanistic study of platelet-activating factor-induced bowel necrosis. Gastroenterology 94: 1.412-1418, 1988 .

60. Winn R, Harlan $J_{3}$ Nadir $B_{*}$ Harker L, Hildebrandt J. Thromboxane $A_{2}$ mediates lung vasoconstriction but not permeability after endotoxin. J Clin Invest 72: $911-918,1983$.

61. Mangino MJ, Anderson CB, Murphy MK, Brunt E, Turk J. Mucosal arachidonate metabolism and intestimal ischemia-reperfusion injury. Am $J$ Physiol 257: G299-G307, 1989.

62. Petrone WF, English DK, Wong K, McCord JM. Free radicals and inflammation: superoxide dependent activation of a neutrophil chemotactic factor in plasma. Proc Natl Acad Sci USA 77: 1159-1163, 1980.

63. Tanabe $M$, Terashita $Z$, Nishikawa $K$, Hirata $M$. Inhibition of coronary circulatory failure and thromboxane $A_{2}$ release during coronary occlusion and reperfusion. $J$ Cardiovase Pharmacol $6: 442 \times 448,1984$.

64. Filep J, Hermán F, Braquet $\mathrm{P}$, Mózes $\mathrm{T}$. Increased levels of platelet-activating factor in blood following intestinal ischemia in the dog. Biochem Biophys Res Comm 158: 353 $359,1989$.

65. Montrucchio G, Alloatti G, Tetta $C$, De Luca R, Suanders RN, Emannelli G, Camussi G. Release of platelet-activating factor from ischemic-reperfused rabbit heart. Am J Physiol 256: H11236-H1246, 1989.

66. Sasaki K, Ueno A, Katori M, Kikawada R. Detection of leukotriene $\mathrm{B}_{4}$ in cardiac tissue and its role in infarct extension through leukocyte migration. Cardiovasc Res 22: 142$148,1988$. 
67. Hughes $\mathrm{H}_{5}$ Farhood $\mathrm{A}$, Jaeschke $\mathrm{H}$. Role of leukotriene $\mathrm{B}_{4}$ in the pathogenesis of hepatic ischemia-reperfusion injury in the rat. Prostag Leukotr Ess 45: 113-119, 1992.

68. Lehr HA, Guhlmann A, Nolte D, Keppler D, Messmer K. I_eukotrienes as mediators in ischemia-reperfusion injury in a microcirculation model in the hamster. $I$ Clin Invest 87 : 2036-2041, 1991.

69. Lad N, Williams TJ, Booth RFG. Neutrophil infiltration into the ischaemic/reperfused rabbit isolated myocardium: effect of PF-5901 and cycloheximide. Eur J Pharmacol $223: 163-171,1992$.

70. Cambria RA, Anderson RJ, Dikdan G, Lysz TW, Hobson II RW. The influence of arachidonic acid metabolites on leukocyte activation and skeletal muscle injury after ischemia and reperfusion. $J$ Vasc Surg 1.4: 549-556, 1991.

71. Otamiri $T$, Tagesson $C$. Role of phospholipase $A_{2}$ and oxygenated free radicals in mucosal damage after small intestinal ischemia and reperfusion. Am $J$ Surg 157: 562$565,1989$.

72. Otamiri $T$, Lindahl $M$, Tagesson $C$. Phospholipase $A_{2}$ inhibition prevents mucosal damage associated with small intestinal ischaemia in rats. Gut 29:489-494, 1988.

73. Kubes $\mathbb{P}$, Ibbotson $\mathrm{G}$, Russell J, Wallace JL, Granger DN. Role of platelet-activating factor in ischemia/reperfusion-induced leukocyte adherence. Am I Physiol 259: G300G305, 1990.

74. Montrucchio G, Alloatti G, Mariano F, Comino A, Cacace G, Polloni R, De Filipi PG, Emanuelli G, Camussi G. Role of platelet-activating factor in polymorphonuclear neutrophil recruitment in reperfused ischemic rabbit heart. Am J Pathol 142: 471-480, 1993.

75. Ioculano M, Squadrito F, Altavilla D, Canale P, Campo GM, Bussolino F, Sardella A, Una $\mathrm{G}$, Caputi AP. Protective effects of $\mathrm{L}-659,989$, a platelet-activating factor receptor antagonist, in myocardial ischemia and reperfusion in rats. I Cardiovasc Pharmacol 23: $7-12,1994$.

76. Zhou W, McCollum MO, Levine BA, Olson MS. Inflammation and platelet-activating factor production during hepatic ischemia/reperfusion. Hepatology $16: 1236-1240,1992$.

77. Rubin B, Smith A, Romaschin A, Walker P. Participation of the complement system in ischemia/reperfusion injury. Microcirc Endoth Lymphatics 5: 207-221, 1989.

78. Rubin BR, Smith A, Liauw S, Isenman D, Romaschin AD, Walker PM. Complement activation and white cell sequestration in postischemic skeletal muscle. Am J Physiol 259: H525-H531, 1990 .

79. Rubin BB, Smith A, Liauw S, Isenman D, Romaschin AD, Walker PM. Complement activation and white cell sequestration in postischemic skeletal muscle. Am $J$ Physiol 259: H525-H531, 1990.

80. Crawford MH, Grover FL, Kolb WP, McMahan A, O'Rourke RA, McManus LM, Pinckard RN. Complement and neutrophil activation in the pathogenesis of ischemic myocardial injury. Circulation $78: 1449-1458,1988$.

81. Kagiyama A, Savage HE, Michael LH, Hanson G, Entman ML, Rossen RG. Molecular basis of complement activation in ischemic myocardium: identification of specific molecules of mitochondric origin that bind human Clq and fix complement.. Circ Res 64: 607-615, 1989.

82. Hayes G, Liauw S, Romaschin AD, Walker PM. Separation of reperfusion injury from ischemia-induced necrosis. Surg Forum 39: 306-308, 1988. 
83. Lindsay TF, Hill J, Ortiz F, Rudolph A, Valeri CR, Hechtman HB, Moore FD. Blockade of complement activation prevents local and pulmonary albumin leak after lower torso ischemia-reperfusion. Ann Surg 216:677-683, 1992.

84. Gibbs SAL, Weiser MR, Kobzik L, Valeri CR, Shepro D, Hechtman HB. P-selectin mediates intestinal ischemic injury by enhancing complement deposition. Surgery 119: $652-656,1996$.

85. Tonnesen MG, Anderson DC, Springer TA, Knedler A, Avdi N, Henson PM. Adherence of neutrophils to cultured human microvascular endothelial cells. Stimulation by chemotactic peptides and lipid mediators and dependence upon the Mac-1, LFA-1, gp I 50,95 glycoprotein family. J Clin invest 83: 637-646, 1989.

86. Webster RO, Hong SR, Johnston Jr. RB, Henson PM. Biological effects of the human complement fragments $\mathrm{C} 5 \mathrm{a}$ and $\mathrm{C} 5 \mathrm{a}$ des arg on neutrophil function. Immunopharmacology 2: 201-219, 1980.

87. Baggiolini M, Walz A, Kunkel SL. Neutrophil-activating peptide/LL-8, a novel cytokine that activates neutrophils. $J$ Clin Invest 84: 1045-1049, 1989.

88. Kunkel SL, Standiford T, Kasahara K, Strieter RM. Interleukin-8: the major neutrophil chemotactic factor in the lung. Exp Lung Res 17: 17-23, 1991.

89. Sauder DN, Mounessa NL, Katz SI, Dinarello CA, Gallin JI. Chemotactic cytokines: the role of leukocyte pyrogen and epidermal cell thymocyte-activating factor in neutrophil chemotaxis. J Immunol 132: 828-832, 1984.

90. Ming WJ, Bersani L, Mantovani A. Tumor necrosis factor is chenotactic for monocytes and polymorphonuclear leukocytes. J Immunol 138: 1469-1474, 1987.

91. Larsen $C G$, Anderson $A O$, Oppenheim JJ, Matsushima K. Production of interleukin-8 by human dermal fibroblasts and keratinocytes in response to interleukin-1 or tumour necrosis factor. Immunology 68: 31-36, 1989.

92. Von Asmuth EJU, Van der Linden CJ, Leeuwenberg JFM, Butrman WA. Involvement of the CD116/CD18 integrin, but not of the endothelial cell adhesion molecules ELAM1 and ICAM-1 in tumor necrosis factor- $\alpha$ induced neutrophil toxicity. I Immunol 147 : 3869-3875, 1991.

93. Von Asmuth EJU, Buurman WA. Endothelial cell-associated plateletactivating factor (PAF), a costimulatory intermediate in tumor necrosis factor- $\alpha$ (TNF- $\alpha$ ) induced $\mathrm{H}_{2} \mathrm{O}_{2}$ release by adherent neutrophil leukocytes. J Immunol 154: 1383-1390, 1995.

94. Strieter RM, Coletti LM, Metinko AP, Rolfe MW, De Meester SR, Standiford TJ, Kunkel SL. The role of cytokine networks in mediating inflammation and ischemiareperfusion injury. In Schlag G, Redl H, Traber D (eds). Shock, Sepsis and Organ Failure. Berlin: Springer Verlag, pp. 205-227, 1993.

95. Kasama T, Kobatashi K, Fukushima T, Tabata M, Ohno I, Negishi M, Ide H, Takahashi $T$, Niwa $Y$. Production of interleukin 1-like factor from human peripheral blood monocytes and polymorphonuclear leukocytes by superoxide anion: the role of interleukin 1 and reactive oxygen species in inflamed sites. Clin Immunol Immunopathol 53: $439-448,1989$.

96. Gougerot-Pocidalo M-A, Roche $\mathrm{Y}$, Fay M, Perianin A, Bailly S. Oxidative injury amplifies interleukin-l-like activity produced by human monocytes. Int I Immunopharmacol 11: $961-969,1989$. 
97. Deforge LE, Fantone JC, Kenney JS, Remick DG. Oxygen radical scavengers selectively inhibit interleukin 8 production in human whole blood. I Clin Invest 90: 2123-2129, 1992 .

98. Ghezzi $\mathrm{P}$, Dinarello $\mathrm{CA}$, Bianchi M, Rosandich ME, Repine JE, White $\mathrm{CW}$. Hypoxia increases production of interleukin-1. and tumor necrosis factor by human monomuclear cells. Cytokine 3: 189-194, 1991.

99. Ala Y, Palluy O, Favero J, Bonne C, Modat G, Dornand J. Hypoxia/reoxygenation stimulates endothelial cells to promote interleukin-1 and interleukin-6 production. Effects of free radical scavengers. Agents Actions 37: 134-139, 1992.

100. Winn RK, Liggitt D, Vedder NB, Paulson JC, Harlan JM. Anti-P-selectin monoclonal antibody attenuates reperfusion injury to the rabbit ear. $J$ Clin Invest 92: 2042-2047, 1993

101. Weyrich AS, Ma X-L, Albertine KH, Lefer AM. In vivo neutralization of P-selectin protects feline heart and endothelium in myocardial ischemia and reperfusion injury. $J$ Clin Invest 91: 2620-2629, 1993.

102. Lefer" AM, Ma X-L. PMN adherence to cat ischemic-reperfused mesenteric vascular endothelium under flow: role of P-selectin. $J$ Appl Physiol 76: 33-38, 1994.

103. Winn RK, Paulson JC, Harlan JM. A monoclonal antibody to P-selectin ameliorates injury associated with hemorrhagic shock in rabbits. Am J Physiol 267: H2391-H2397, 1994.

104. Palluy O, Morliere L, Gris JC, Bonne C, Modat G. Hypoxia/reoxygenation stimulates endothelium to promote neutrophil adhesion. Free Radical Biol Med 13: 21-30, 1992.

105. Patel KD, Zimmerman GA, Prescott SM, MeEver RP, Mclntyre TM. Oxygen radicals induce human endothelial cells to express GMP-140 and bind neutrophils. $J$ Cell Biol 112: 749-759, 1991 .

106. Foreman KE, Vaporciyan AA, Bonish BK, Jones ML, Johnson KJ, Glovsky MM, Eddy SM, Ward PA. C5a-induced expression of P-selectin in endothelial cells. I Clin Invesi 94: 1147-1155, 1994.

107. Weller A, Isenmann S, Vestweber D. Cloning of the mouse endothelial selectins. Expression of both $\mathbb{E}$ - and $\mathrm{P}$-selectin is inducible by tumor necrosis factor alpha. $I$ Biol Chem 267: 15176-15183, 1992 .

108. Breviario F, Bertocchi $\mathbb{F}$, Dejana $E$, Bussolino F. $\mathbb{L}$-1-induced adhesion of polymorphonuclear leukocytes to cultured human endothelial cells. Role of plateletactivating factor. I Immunol 141:3391-3397, 1988.

109. Lorant DE, Patel KD, Mclntyre TM, McEver RP, Prescott SM, Zimmerman GA. Coexpression of GMP-140 and PAF by endothelium stimulated with histamine or thrombin: a juxtacrine system for adhesion and activation of neutrophils. $J$ Cell Biol $115: 223-234,1991$

110. Gaboury J, Anderson DC, Kubes P. Molecular mechanisms involved in superoxideinduced leukocyte-endothelial cell interactions in vivo. Am $J$ Physiol 266: H637-H642, 1994.

111. Lewis MS, Whatley RE, Cain P, Mcintyre TM, Prescott SM, Zimmerman GA. Hydrogen peroxide stimulates the synthesis of platelet-activating factor by endothelium and induces endothelial cell-dependent neutrophil adhesion. J Clin Invest 82: 2045-2055, 1988 . 
112. Budd JM, Kirtland SJ, Baum H. Enhanced adhesion of polymorphonuclear lenkocytes to anoxic cultured vascular endothelium. Cell Signal 2: 305-310, 1990.

113. Klein $\mathrm{CL}$, Köhler $\mathrm{H}$, Bittinger F, Otto M. Hermanns I, Kitkpatrick CJ. Comparative studies on vascular endothelium in vitro. 2. Hypoxia: Its influences on endothelial cell proliferation and expression of cell adhesion molecules. Pathobiology 63: 1-8, 1995.

114. Bouma MG, Jeunhomme TMMA, De Abreu RA, Van den Wildenberg FAM, Butrman WA. Hypoxia/reoxygenation of cultured human endothelium: effects on cellular activation and adenosine release. Submitted for publication.

115. Seekamp A, Till GO, Mulligan MS, Paulson JC, Anderson DC, Miyasaka M, Ward PA. Role of selectins in local and remote tissue injury following ischemia and reperfusion. Am I Pathol 144: 592-598, 1994.

116. Altavilla D, Squadrito F, Ioculano M, Canale P, Campo GM, Zingarelli B, Caputi AP. Eselectin in the pathogenesis of experimental myocardial ischemia-reperfusion injury. Eur J Pharmacol 270: 45-51, 1994.

117. Mihelcic D, Schleiffenbaum B, Tedder TF, Sharar SR, Harlan JM, Winn RK. Inhibition of leukocyte L-selectin function with a monoclonal antibody attenuates reperfusion. injury to the rabbit ear. Blood 84: 2322-2328, 1994.

118. Han KT, Sharar SR, Phillips ML, Harlan JM, Winn RK. Sialyl Lewis oligosaccharide reduces ischemia-reperfusion injury in the rabbit ear. $J$ Immunol 155:4011-4014, 1995.

119. Seekamp A, Mulligan MS, Till GO, Smith CW, Miyasaka M, Tamatani T, Todd III RF, Ward PA. Role of $B 2$ integrins and ICAM-1 in lung injury following ischemiareperfusion of rat hind limbs. Am J Pathol 143: 464-472, 1993.

120. Nolte $D$, Hecht $R$, Schmid $P$, Botzlar A, Menger MD, Neumueller $C$, Sinowatz $F$,

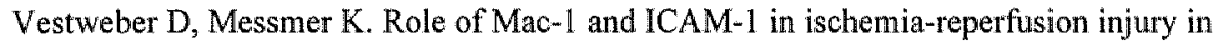

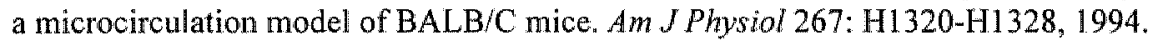

121. Horgan MJ, Wright SD, Malik AB. Antibody against leukocyte integrin (CD18) prevents reperfusion-induced lung vascular injury. Am J Physiol 259: L_315-L_319, 1990.

122. Horgan MJ, Ge M, Gu J, Rothlein R, Malik AB. Role of ICAM-1 in neutrophil-mediated lung vascular injury after occlusion and reperfusion. Am J Physiol 261: H1578-H1584, 1991.

123. Ma X Lefer DJ, Lefer AM, Rothlein R. Coronary endothelial and cardiac protective effects of a monoclonal antibody to intercel|lular adhesion molecule-1 in myocardial ischemia and reperfusion. Circulation 86: 937-946, 1992.

124. Yamazaki T, Seko Y, Tamatani T, Miyasaka M, Yagita H, Okumura K, Nagai R, Yazaki $Y$. Expression of intercellular adhesion molecule- $\mathbb{L}$ in rat heart with ischemia/reperfusion and limitation of infarct size by treatment with antibodies against cell adhesion molecules. Am J Pathol 143: 410-418, 1993.

125. Vollmar B, Glasz J, Menger MD, Messmer K. Leukocytes contribute to hepatic ischemia/reperfusion injury via intercellular adhesion molecule-1-mediated venuilar adherence. Surgery 117: 195-200, 1995.

126. Suzuki M, Asako H, Kubes P, Jennings S, Grisham MB, Granger DN. Neutrophilderived oxidants promote leukocyte adherence in postcapillary venules. Microvasc Res 42: 125-138, 1991.

127. Argenbright LW, Letts $L G$, Rothlein R. Monoclonal antibodies to the leukocyte membrane CD18 glycoprotein complex and to intercellular adhesion molecule-1 inhibit leukocyte-endothelial adhesion in rabbits. J Leukoc Biol 49: 253-257, 1991. 
128. Zimmerman BJ, Holt JW, Paulson JC, Anderson DC, Miyasaka M, Tamatani $T$, Todd $R F$, Rusche $\mathrm{JR}_{*}$ Granger DN. Molecular determinants of lipid mediator-induced leukocyte adherence and emigration in rat mesenteric venules. Am $J$ Physiol 266: H847H853, 1994.

129. Bradley IR, Johnson DR, Pober JS. Endothelial activation by hydrogen peroxide. Selective increases of intercellular adhesion molecule-1 and major histocompatibility complex class 1. Am J Pathol 142: 1598-1609, 1993.

130. Gasic AC, McGuire $\mathrm{G}$, Krater $\mathrm{S}$, Farhood AI, Goldstein MA, Smith $\mathrm{CW}$, Entman ML, Taylor AA. Hydrogen peroxide pretreatment of perfused canine vessels induces ICAM-1 and CD18-dependent neutrophil adherence. Circulation 84:2154-2166, 1991.

131. Hakkert BC, Kuijpers TW, Leeuwenberg JFM, Van Mourik JA, Roos D. Neutrophil and monocyte adherence to and migration across monolayers of cytokine-activated endothelial cells: the contribution of CD18, ELAM-1, and VLA-4. Blood 78: 2721-2726, 1991.

132. Kuijpers TW, Hakkert BC, Hart MHL, Roos D. Neutrophil migration across monolayers of cytokine-prestimulated endothelial cells: a role for platelet-activating factor and IL-8. JCell Biol 117: 565-572, 1992.

133. Muller WA, Weigl SA, Deng X, Phillips DM. PECAM-1 is required for transendothelial migration of leukocytes. I Exp Med 178: 449-460, 1993.

134. Asako H, Kubes P, Baethge BA, Wolf RE, Granger DN. Colchicine and methotrexate reduce leukocyte adherence and emigration in rat mesenteric venules. Inflammation 16: $45-56,1992$.

135. Goldman G, Welbourn R, Klausner JM, Valeri CR, Shepro D, Hechtman HB. Oxygen free radicals are required for ischemia-induced leukotriene $B_{4}$ synthesis and diapedesis. Surgery 111:287-293, 1992.

136. Goldman G, Welbourn R, Paterson IS, Klausner IM, Kobzik L, Valeri CR, Shepro D, Hechtman F-BB. Ischemia-induced neutrophil activation and diapedesis is lipoxygenase dependent. Surgery 107: 428-433, 1990.

137. Deitch EA. Multiple organ failure. Pathophysiology and potential future therapy. Anm Surg $216: 117-134,1992$.

138. Granger DN. Role of xanthine oxidase and granulocytes in ischemia-reperfusion injury. Am J Physiol 24: H1269-H1275, 1988.

139. Badylak SF, Simmons A, Turek J, Babbs CF. Protection from reperfusion injury in the isolated rat heart by postischaemic deferoxamine and allopurinol administration. Cardiovasc Res 21: 500-506, 1987.

140. Soong C, Young IS, Rowlands BJ, Trimble ER, Bartos D'Sa AAB. Use of allopurinol to reduce lower-limb swelling following femoropopliteal bypass grafting. $\mathrm{Br} J$ Surg 81 : 607,1994 (Abstract).

141. Lelli $\mathfrak{H}$, Pradhan S, Mason Cobb L. Prewention of postischemic injury in immature intestine by deferoxamine. J Surg Res 54: 34-38, 1993.

142. Gutteridge IM, Richmond $\mathrm{R}$, Halliwel B. Oxygen free-radicals and lipid peroxidation: inhibition by the protein ceruloplasmin. FEBS Left 112: 269-272, 1980.

143. Hernandez LA, Grisham MB, Granger DN. A role for iron in oxidant-mediated ischemic injury to intestinal microvasculature. Am J Physiol 253: G49-G53, 1987.

144. Reddy BR, Kloner RA, Przyklenk K. Early treatment with deferoxamine limits myocardial ischemic/reperfusion injury. Free Radic Biol Med 7: 45-52, 1989. 
145. Walker PM, Lindsay TF, Labbe R, Mickle DA, Rornaschin AD. Salvage of skeletal muscle with free radical scavengers. J Vasc Surg 5: 68-75, 1987.

146. Bulkley GB. The role of oxygen free radicals in human disease processes. Surgery 94 : 407-411, 1983.

147. Leff JA, Parsons PE, Day CE, Taniguchi $N_{*}$ Jochum M, Fritz H, Moore FA, Moore EE, McCord IM, Repine JE. Serum antioxidants as predictors of adult respiratory distress syndrome in patients with sepsis. Lancet 341:777-780, 1993.

148. Parks DA, Bulkley GB, Granger DN. Role of oxygen-derived free radicals in digestive tract diseases. Surgery $94: 15-22,1983$.

149. Portz SJ, Lesnefsky EJ, Van Benthuysen KM, Repine JE, Parker NB, McMurtry IF, Horwitz LD. Dimethylthiourea, but not dimethylsulfoxide, reduces canine myocardial infarct size. Free Radic Biol Med 7: 53-58, 1989.

150. England MD, Caravochi CC, O'Brien JF, Solis E, Pluth JR, Orszulak TA, Kaye MP, Schass HV. Influence of antioxidants (mannitol and allopurinol) on oxygen free redical generation during and after cardiopulmonary bypass. Circulation 74, Suppl. IIII: 134-137, 1986.

151. Macgovern GJ, Bolling SF, Carole AS, Bulkley BH, Gardner TJ. The mechanism of mannitol in reducing ischemic injury: hyperosmolarity or bydroxyl scavenger. Circulation 70, Suppl. I: 43-57, 1980.

152. Paterson IS, Klausner JM, Goldman G, Pugatch R, Feingold H, Allen P, Mannick JA, Valeri CR, Shepro D, Hechtman HB. Pulmonary edema following aneurysm surgery is modified by mannitol. Ann Surg 210: 796-801, 1989.

153. Johnson G, Lefer AM. Protective effects of a novel 21 -aminosteroid during splanchnic artery occlusion shock. Circ Shock 30: 155-164, 1990.

154. Hall ED, Pazara KE, Braughler JM. 21-Aminosteroid lipid peroxidation inhibitor U74006F protects against cerebral ischemia in gerbils. Stroke 19: 997-1001, 1988.

155. Thomas PD, Mao GD, Rabinovitch A, Poznansky MJ. Inhibition of superoxidegenerating NADPH oxidase of human neutrophils by lazaroids (21-aminosteroids and 2methylaminochromans). Biochem Pharmacol 45: 241-251, 1993.

156. McCay PB. Vitamin E: interactions with free radicals and ascorbate. Ann Rev Nutr 5: 323-340, 1985.

157. Packer JE, Slater TF, Wilson RL. Direct observation of a free radical interaction between vitamin $E$ and vitamin C. Nature 278: 737-738, 1979.

158. Guarnieri C, Ferrari R, Visioli O, Caldarera CM, Nayler WG. Effects of $\alpha$-tocopherol on hypoxic-perfused and reoxygenated rabbit heart muscle. I Mol Cell Cardiol 10: 893-906, 1978.

159. Marubayashi S, Dohi K, Ochi K, Kawasaki T. Role of free radicals in ischemic rat liver cell injury: prevention of damage by $\alpha$-tocopherol administration. Surgery 99: 184-191, 1986.

160. Frei B, Kim MC, Ames BA. Ubiquinol 10 is an effective lipid soluble antioxidant at physiological concentrations. Proc Natl Acad Sci 87: 4879-4883, 1990.

161. Choudhury NA, Sakaguchi S, Koyano K. Matin AFM, Muro H. Free radical injury in skeletal muscle ischemia and reperfusion. $J$ Surg Res 51:392-398, 1991.

162. Reilly PM, Schiller HJ, Bulkley GB. Pharmacologic approach to tissue injury mediated by free radicals and other reactive oxygen metabolites. Am J Surg 161: 488-503, 1991. 
163. Forman MB, Puett DW, Cates CU, McCroskey DE, Beckman JK, Greene HL, Virmani R. Glutathione redox pathway and reperfusion injury. Effect of $\mathrm{N}$-acetylcysteine on infaret size and ventricular function. Circulation 78: 202-213, 1988.

ل64. Wagner PD, Mathie-Costello O, Bebout DE, Gray AT, Natterson PD, Glennow C. Protection agalnist pulmonary $\mathrm{O}_{2}$ toxicity by $N$-acetylcysteine. Eur Resp $J 2: 116-126$, 1989.

165. Cecconi $\mathrm{C}$, Curello $\mathrm{S}$, Cargnoni $\mathrm{A}$, Ferrari $\mathrm{R}$, Albertini $\mathrm{A}$, Visioli $\mathrm{O}$. The role of glutathione status in the protection against ischaemic and reperfusion damage: effects of $N$-acetylcysteine. J Mol Cell Cardiol 20:5-13, 1988.

166. Bernard GR. $N$-acetylcysteine in experimental and clinical acute lung injury. Am $J \mathrm{Med}$ 91: $54-59,1991$

167. Cronstein BN, Kramer SB, Weissmann G, Hirschhorn R. Adenosine: a physiological modulatot of superoxide amion generation by human neutrophils. $J$ Exp Med 158: 1160 $1177,1983$.

168. Zimmerman JJ, Zuk SM, Millard JR. In vitro modulation of human neutrophil superoxide anion generation by various calcium channel antagonists used in ischemiareperfusion resuscitation. Biochem Pharmacol 38: 3601-3610, 1989.

169. Carden DL, Korthuis RJ. Mechanisms of postischemic vascular dysfunction in skeletal muscle: implications for therapeutic intervention. Microcirc Endothelium Lymphatics 5: $277-298,1989$.

170. Bajaj AK, Cobb MA, Virmani R, Gay JC, Light RT, Forman MB. Limitation of myocardial reperfusion injury by intravenous perfluorochemicals: role of neutrophil activation. Circulation 79: 645-656, 1989.

171. Babbitt DG, Forman MB, Jones R, Bajaj AK, Hoover RL. Prevention of neutrophilmediated injury to endothelial cells by perfluorochemical. Am $J$ Pathol 136: 451-459, 1990.

172. Koike K, Moore EE, Moore FA, Carl VS, Pitman JM, Banerjee A. Phospholipase $\mathrm{A}_{2}$ inhibition decouples lung injury from gut ischemia-reperfusion. Surgery 112: 173-180, 1992.

173. Boros M, Karácsony G, Kaszaki J, Nagy S. Reperfusion mucosal damage after complete intestinal ischemia in the dog: the effects of antioxidant and phospholipase $\mathrm{A}_{2}$ inhibitor therapy. Surgery 113: 184-191, 1993.

174. Lehr H-A, Hibner C, Nolte D, Kohlschïtter A, Messmer K. Dietary fish oil blocks the microcirculatory manifestations of ischemia-reperfusion injury in striated muscle in hamsters. Proc Natl Acad Sci USA 88: 6726-6730, 1991.

175. Kromhout D, Bosschieter EB, De Lezenne-Coulander $C$. The inverse relation between fish consumption and 20-year mortality from coronary heart disease. $N$ Eng $J$ Med 312 : $1205-1209,1985$.

176. Kromann N, Green A. Epidemiological studies in the Upernavik district, Greenland: incidence of some chronic diseases 1950-1974. Acta Med Scand 208: 401-406, 1980.

177. Yin M, Kurvers HAJM, Buurman WA, Tangelder GJ, Booster MH, Daemen JHC, Kondracki S, Kootstra G. Platelet-activating factor antagonist TCV-309 protects rat kidney against ischemia-reperfusion injury. Transplant Proc 27: 2844-2846, 1995.

1.78. Yin M, Burman WA, Daemen JHC, Kootstra G. The PAF antagonist TCV-309 reduces graft PMN infiltration and enhances early function of 24-hour-preserved rat kidneys with long warm ischemia. Transplantation 61: 1443-1446, 1996. 
179. Walcher $F$, Marzi I, Fischer R, Bauer M, Larsen R. Platelet-activating factor is involwed in the regulation of pathological leukocyte adhesion after liver transplantation in the rat. J Surg Res 61: 244-249, 1996.

180. Qayumi AK, Jamieson WRE; Poostizadeh A. Effects of platelet-activating factor antagonist CV-3988 in preservation of heart and lung for transplantation. Am Thorac Surg 52: 1026-1032, 1991.

181. Colletti LM, Remick DG, Burtch GD, Kunkel SL, Strieter RM, Campbell Jr DA. Role of tumor necrosis factor- $\alpha$ in the pathophysiologic alterations after hepatic ischemia/reperfusion in the rat. J Clin Inrest 85:1936-1943, 1990.

182. McCurry KR, Campbell Jr DA, Scales WE, Warren JS, Remick DG. Tumor necrosis factor, interleukin 6, and the acute phase response following hepatio ischemia/reperfusion. $J$ Surg Res 55: 49-54, 1993.

183. Squadrito $F$, Altavilla D, Zingarelli $B$, Ioculano $M$, Calapai $G$, Campo GM, Miceli $A$, Caputi AP. Tumor necrosis factor involvement in myocardial ischaemia-reperfusion injury. Eur J Pharmacol 237: 223-230, 1993.

184. Sternbergh III WC, Tuttle TM, Makhoul RG, Bear HD, Sobel M, Fowler III AA. Postischemic extremities exhibit immediate release of tumor necrosis factor. $J$ Vasc Swrg 20: 474-481, 1994.

185. Cross A. Novel approaches to the treatment of sepsis: lessons learned and future directions. Shock 6: S71-S74, 1996.

186. Glauser MP, Heumann D, Baumgartner JD, Cohen J. Pathogenesis and potential strategies for prevention and treatment of septic shock: an update. Clin lnfect Dis" 18 : S205-\$216, 1994.

187. Fisher CJ, Opal SM, Dhainaut $J$, et al. Infuence of an anti-tumor necrosis factor monoclomal antibody on cytokine levels in patients with sepsis. Crit Care Med 21: 318 $327,1993$.

188. Seekamp A, Warren JS, Remick DG, Till GO, Ward PA. Requirements for tumor necrosis factor- $\alpha$ and interleukin- 1 in limb ischemia/reperfusion injury and associated lung injury. Am J Pathol 143: 453-463, 1993.

189. Sorkine P, Setton A, Halpern P, Miller A, Rudick V, Marmor S, Klausner JM, Goldman G. Soluble tumor necrosis factor receptors reduce bowel ischemia-induced lung permeability and neutrophil sequestration. Crit Care Med 23:1377-1381, 1995.

190. Relton JK, Rothwell NJ. Interleukin-1 receptor antagonist inhibits ischaemic and exitotoxic neuronal damage in the rat. Brain Res Bull 29:243-246, 1992.

191. Pellicane JV, DeMaria EJ, Abd-Elfattah A, Reines HD, Vannice JL, Carson KW. Interleukin-1 receptor antagonist improves survival and preserves organ adenosine-5'triphosphate after hemorrhagic shock. Surgery 114: 278-284, 1993.

192. Selkido N, Mukaida N, Harada A, Nakanishi I, Watanabe Y, Matsushima K. Prevention of lung reperfusion injury in rabbits by a monoclonal antibody against interleukin-8. Nature 365: 654-657, 1993.

193. Wickersham NE, Loyd JE, Johnson JE, McCain RW, Christman JW. Acute inflammation in a sheep model of unilateral lung ischemia: the role of interleukin-8 recruitment of polymorphonuclear leukocytes. Am J Respir Cell Mol Biol 9: 199-204, 1993.

194. Wahl S, McCarthy-Francis N, Mergenhagen SE. Inflammatory and immunomodulatory roles of TGF-B. Immunol Today 10:258-261, 1989. 
195. Lefer $A M$. Mechanisms of the protective effects of transforming growth factor- $B$ in reperfusion injury. Bhochem Pharmacol 42: 1323-1327, 1991.

196. Tumer $M_{4}$ Chantry $D$, Katsikis $\mathbb{P}$, Berger $A$, Brennan $\mathbb{F}$, Feldmann $M$. Induction of the interleukin-1 receptor antagonist protein by transforming growth factor- $B$. Ew $J$ Immunol 21: 1635-1639, 1991 .

197. Davenpeck KL, Gauthier TW, Albertine KH, Lefer AM. Role of P-selectin in microvascular leukocyte-endothellial interaction in splanchnic ischemia-reperfusion. $A m$ JPhysiol 267: $\mathrm{H} 622 \mathrm{H} 630,1994$.

198. Carden DL, Young JA, Granger DN. Pulmonary microvascular injury after intestinal ischemia-teperfusion: role of P-selectin. J Appl Physiol 75: 2529-2534, 1993.

199. Murohara T, Delyani JA, Albelda SM, Lefer AM. Blockade of platelet endothelial cell adhesion molecule-1 protects against myocardial ischemia and reperfusion injury in cats. J Immunol 156: 3550-3557, 1996.

200. Fox IH, Kelley WN. The role of adenosine and 2'-deoxyadenosine in mammalian cells. Ann Rev Brochem 47: 655-686, 1978.

201. Collis MG, Hourani SM. Adenosine receptor subtypes. Trends Pharmacol Sci 14: 360$366,1993$.

202. Stiles GL. Adenosine receptors. J Biol Chem 267: 6451-6454, 1992 .

203. Olsson RA, Pearson ID. Cardiovascular purinoreceptors. Physiol Rev 70: 761-845, 1990.

204. Newby AC. Adenosine and the concept of retaliatory metabolites. Trends Biochem Sci 9 : $42-44,1984$.

205. Sandhu GS, Burrier AC, Janero DR. Adenosine deaminase inhibitors attenuate ischemic injury and preserve energy balance in isolated guinea pig heart. Am $J$ Physiol 265: H1249-H1256, 1993.

206. Henrichs KJ, Matsuoka H, Schaper W. Enhanced postischemic ATP repletion by pharmacological inhibition of nucleoside washout and catabolism. $J$ Cardiovasc Pharmacol 11:694-700, 1988.

207. Abd-Elfattah AS, Jessen ME Hanan SA, Tuchy G, Wechsler AS. Is adenosine 5'triphosphate derangement or free-radical-mediated injury the major cause of ventricular dysfunction during reperfusion? Circulation 82 (Suppl. 4): IV341-IV350, 1990.

208. Swain JL, Hines JJ, Sabina RL, Holmes EW. Accelerated repletion of ATP and GTP pools in postischemic canine myocardium using a precursor of purine de novo synthesis. Circ Res 51: 102-105, 1982.

209. Bolling SF, Childs KF, Ning X-H. Adenosine's effect on myocardial functional recovery: substrate or signal? J Surg Res 57: 591-595, 1994.

210. Mullane K. Acadesine: the prototype adenosine regulating agent for reducing myocardial ischaemic injury. Cardiovasc Res 27: 43-47, 1993.

211. Zughaib ME, Abd-Elfattah AS, Jeroudi MO, Sun JZ, Sekili S, Tang XL, Bolli X. Augmentation of endogenous adenosine attenuates myocardial 'stunning' independently of coronary flow or hemodynamic effects. Circulation 88: 2359-2369, 1993.

212. Booster MH, Yin M, Maessen JG, Stubenitsky BM, Wijnen RMH, Kootstra G. Protection of canine renal grafts by renin-angiotensin inhibition through nucleoside transport blockade. Transplant Int 8: 207-213, 1995.

213. Belardinelli L, Linden J, Berne RM. The cardiac effects of adenosine. Prog Cardiovasc Dis 32: 73-97, 1989 . 
214. Josst HG, Steinfelder HJ. Modulation of insulin sensitivity by adenosine: effects on glucose transport, lipid synthesis, and insulin receptors of the adipocyte. Mol Phamacol 22: 614-618, 1982 .

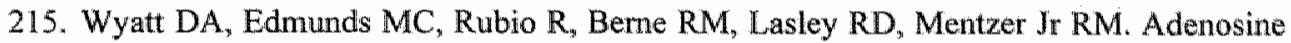
stimulates glycolytic flux in isolated perfused rat hearts by A I-adenosine receptors. $A m J$ Physiol 257: H1952-H1957, 1989.

216. Law WR, Raymond RM. Adenosine potentiates insulin-stimulated myocardial glucose uptake in vivo. Am J Physiol 254: H970-H975, 1988.

217. Schrier DJ, Imre KM. The effects of adenosine agonists on human neutrophil function. $J$ Immunol 137: 3284-3289, 1986.

218. Richardt G, Waas W, Kranzhomig R, Mayer E, Schomig A. Adenosine inhibits exocytotic release of endogenous noradrenalin in rat heart: a protective mechanism in early myocardial ischemia. Circ Res 61: 17 17-123, 1987.

219. Ishida T, Yarimizu K, Gute DC, Korthüs RJ. Mechanisms of ischemic preconditioning. Shock 8: 86-94,1997.

220. Liu GS, Thomton J, Van Winkle D, Stanley AWH, Olsson RA, Downey JM. Protection against infarction afforded by preconditioning is mediated by $\mathrm{A} 1$ adenosine receptors in rabbit heart. Circulation 84: 350-356, 1991.

221. Liu GS, Richards SC, Olsson RA, Mullane KM, Walsh RS, Downey JM. Evidence that the adenosine $\mathrm{A} 3$ receptor may mediate the protection afforded by preconditioning in the isolated rabbit heart. Cardiovasc Res 28: 1057-1061, 1994.

222. Downey JM. Ischemic preconditioning. Nature's own cardioprotective intervention. Trends Cardiovasc Med 2: 170-176, 1992.

223. Meldrum DR, Mitchell MB, Banerjee A, Harken AH. Cardiac preconditioning. Induction of endogenous tolerance to ischemia-reperfusion injury. Arch Surg 128: 1208$1211,1993$.

224. Lee HT, Schroeder CA, Shah PM, Babu SC, Thompson CI, Belloni FL. Preconditioning with ischemia or adenosine protects skeletal muscle from ischemic tissue reperfusion injury. J Surg Res 63: 29-34, 1996.

225. Giblett ER, Anderson JE, Cohen F, Pollara B, Meuwissen H. Adenosine deaminase deficiency in two patients with severely impaired cellular immunity. Lancet 2: 1067 . $1069,1972$.

226. Cronstein BN, Daguma L, Nichols D, Hutchison AJ, Williams M. The adenosine/neutrophil paradox resolved: human neutrophils posses both $\mathrm{Al}$ and $\mathrm{A2}$ receptors that promote chemotaxis and inhibit $\mathrm{O} 2$-generation, respectively. $I$ Clin Imest 85: $1150-1157,1990$.

227. Salmon JE, Cronstein BN. Fc $\gamma$ receptor-mediated functions in neutrophils are modulated by adenosine receptor occupancy: $A 1$ receptors are stimulatory and $A 2$ receptors are inhibitory. I Immunol 145: 2235-2240, 1990.

228. Cronstein BN, Levin RJ, Philips M, Hirschhorn R, Abramson SB, Weissmann G. Neutrophil adherence to endothelium is enhanced via adenosine $A_{1}$ receptors and inhibited via adenosine $A_{2}$ receptors. J Immunol 148: 2201-2206, 1992.

229. Cronstein BN. Adenosine, an endogenous anti-inflammatory agent. I Appl Physiol 76: 5$13,1994$. 


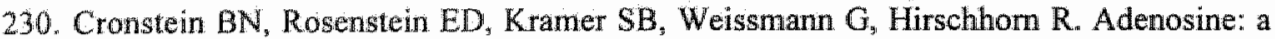
physiologic modulator of superoxide anion generation by human neutrophils. Adenosine acts via an $\mathrm{A}_{2}$ receptor on human neutrophils. J Imtmunol 135 : 1366-1371, 1985.

231. Cronstein BN, Levin RI, Belanoff $J_{*}$ Weissman $G$, Hirschhom $R$. Adenosine: an endogenous inhibitor of neutrophil-mediated injury to endothelial cells. $/ \mathrm{Clin}$ Invest 78 : $760-770,1986$.

232. Nolte D, Lorenzen A, Lehr H-A, Zinmer F-J, Klotz K-N, Messmer K. Reduction of postischemic leukocyte-endothelium interaction by adenosine via $\mathrm{A}_{2}$ receptor. NaunynSchmiedeberg's Arch Pharmacol 346: 23,4-237, 1992.

233. Grisham MB, Hernandez LA, Granger DN. Adenosine inhibits ischemia-reperfusioninduced leukocyte adherence and extravasation. Am J Physiol 257: H1334-H1339, 1989.

234. Olafsson B, Forman MB, Puett DW, Pou A, Cates CU, Friesinger GC, Virmani R. Reduction of reperfusion injury in the canine preparation by intracoronary adenosine: importance of the endothelium and the no-reflow phenomenon. Circulation 76: 1135 $1145,1987$.

235. Asako H., Wolf RE, Granger DN. Leukocyte adherence in rat mesenteric venules: effects of adenosine and methotrexate. Gastroenterology 104: 31-37, 1993.

236. Firestein GS, Bullough DA, Erion MD, Jimenez $R$, Ramirez-Weinhouse $M$, Barankiewicz J, Smith CW, Gruber HE, Mullane KM. Inhibition of neutrophil adhesion by adenosine and an adenosine kinase inhibitor. The role of selectins. I Immunol 154: 326-334, 1995.

237. Bullough DA, Magill MJ, Mullane KM, Firestein GS. Carbohydrate- and CD18dependent neutrophil adhesion to cardiac myocytes: effects of adenosine. Cardiovasc Res: 32: 328-334, 1996.

238. Derian CK, Santulli RJ, Rao PE, Solomon HF, Barrett JA. Inhibition of chemotactic peptide-induced neutrophil adhesion to wascular endothelium by cAMP modulators. $J$ Immunol 154: 308-317, 1995.

239. Wollner A, Wollner S, Smith JB. Acting via A2 receptors, adenosine inhibits the upregulation of Mac-1 (CD11b/CD18) expression on FMLP-stimulated neutrophils. Am $J$ Respir Cell Mol Biol 9: 179-185, 1993.

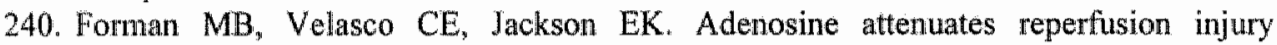
following regional myocardial ischaemia. Cardiovasc Res 27: 9-17, 1993.

241. Collis MG. The vasodilator role of adenosine. Pharmac Ther 41: 143-162, 1989.

242. Bullough DA, Zhang C, Montag A, Mullane KM, Young MA. Adenosine-mediated inhibition of platelet aggregation by acadesine. $A$ novel antithrombotic mechanism in vitro and in vivo. $J C l i n$ Invest 94: 1524-1532, 1994. 
CHAPTER 2

Adenosine Inhibits Neutrophil Degranulation in Activated Human Whole Blood

Involvement of adenosine $\mathrm{A} 2$ and $\mathrm{A} 3$ receptors

Bouma MG, Jeunhomme TMMA, Boyle DL, Dentener MA, Voitenok NN, Van den Wildenberg FA.JM, Buurman WA Journal of Immunology 158: 5400-5408, 1997 


\section{ABSTRACT}

Adenosine acting via $\mathrm{A} 2$ receptors is a potent inhibitor of neutrophil oxidative burst, but its effects and mechanisms of action on neutrophil degranulation have been less well-characterized. We therefore investigated the effects of adenosine and its receptor-specific analogues on neutrophil degranulation in stimulated human whole blood. Adenosine dose-dependently inhibited LPS- and TNF $\alpha$ induced release of the azurophilic granule proteins bactericidal/permeabilityincreasing protein, elastase, and defensins to approximately the same extent, with a maximum inhibition of $70-80 \%$, and $I C_{50}$ ranging from 14 to $24 \mu \mathrm{M}$. The inhibitory effects of adenosine were partially blocked by the $\mathrm{A} 2$ receptor antagonist 3,7-dimethyl-1-propargylxanthine, the A1/A2 antagonist $8(p-$ sulphophenyl)theophylline (PST), and the A1/A3 antagonist xanthine amine congener (XAC), but not by the Al antagonist 1,3-dipropyl-8cyclopentylxanthine. The highly selective A3 agonist $\mathrm{N}^{6}$-(3-iodobenzyl)adenosine-5'-N-methyluronamide (IB-MECA) and the non-selective agonist 2chloroadenosine (2-CAdo) reduced degranulation more potently than the Al agonist $\mathrm{N}^{6}$-cyclopentyladenosine. The inhibitory effects of IB-MECA and 2-CAdo were strongly reversed by XAC, but were not affected by PST. In addition, the adenosine kinase inhibitor GP515 also attenuated degranulation via an adenosine-mediated mechanism. These data indicate that adenosine acts via $A 2$ as well as A3 receptors to inhibit human neutrophil degranulation, and add to the anti-inflammatory potential of adenosine and adenosine-regulating agents towards neutrophil-mediated tissue injury.

\subsection{INTRODUCTION}

Activation of neutrophils (PMN) by appropriate stimuli with subsequent release of a wide range of more or less toxic secretory products is a crucial component of the physiological inflammatory response. These neutrophil products include preformed granule constituents, such as lytic enzymes, other proteins and glycosaminoglycans, as well as nonproteinaceous nongranule materials, such as phospholipids and reactive oxygen species (1). Whereas controlled degranulation and secretion by locally accumulated neutrophils contributes to a protective, limited tissue inflammatory response, exaggerated and uncontrolled systemic activation of neutrophils in various inflammatory conditions, such as sepsis (2) and ischemia/reperfusion (3), may cause a detrimental systemic inflammatory process, resulting in pathological tissue injury. 
Adenosine has been recognized as an important modulator of neutrophil function, particularly with regard to neutrophil superoxide production and neutrophil adherence and cytotoxicity to the vascular endothelium (4-10), and may therefore be protective against neutrophil-mediated tissue injury. Specifically, adenosine is strongly protective against reperfusion damage (11). Also, adenosine-regulating agents, such as acadesine, AICA riboside (5-amino1-B-D-ribofuranosylimidazole-4-carboxamide), adenosine deaminase inhibitors, and an adenosine kinase ( $\mathrm{AK}$ ) inhibitor, provide protection against reperfusion injury (12-15) and endotoxin challenge $(16,17)$ in vivo.

To date, four different receptors have been identified (18), that mediate the effects of adenosine on many cells (A1, A2a, A2b, and A3). Neutrophils have been shown to express adenosine receptors of both Al and A2 types, which have opposing effects on various neutrophil functions. Ligation of neutrophil Al receptors by adenosine at picomolar concentrations enhances neutrophil chemotaxis and adherence $(10,19)$, thereby exerting a pro-inflammatory effect. In contrast, adenosine in micromolar concentrations has been shown to inhibit production of superoxide anion, the presumed parent compound of various reactive oxygen species, via occupation of $A 2$ receptors $(4,9)$. Also, adenosine inhibits neutrophil adherence to endothelium $(6,10)$ and cardiac myocytes $(7)$, acting via A2 receptors on the neutrophil cell surface. Thus, ligation of A2 receptors by adenosine has anti-inflammatory consequences. Similarly, A3 receptors have been implicated in the anti-inflammatory actions of adenosine by inhibiting release of TNF $\alpha$ by human macrophages (20), but expression of A3 receptors on human neutrophils has thus far not been demonstrated.

While in previous studies by Cronstein and coworkers $(21,22)$ it was demonstrated that adenosine strongly reduced superoxide anion generation, at the same time it exerted little effect on the release of beta-glucuronidase and lysozyme by FMLP-stimulated human neutrophils in vitro. Similarly, others (23) have reported that secretion of granule proteins from neutrophils was only modestly affected by adenosine. Thus, while the inhibitory actions of adenosine on neutrophil respiratory burst are well-documented, its effects and mechanism of action on degranulation are less clear.

Therefore, this study was undertaken to evaluate whether adenosine affects release of the granule proteins bactericidal/permeability-increasing protein (BPI), human neutrophil elastase (HNE), and defensins (HNP) by neutrophils in an ex vivo human whole blood model, and to assess the role of specific adenosine receptors. In addition, the effects of the adenosine-regulating agent GP515, a novel AK inhibitor, on neutrophil degranulation in this model were determined. 


\subsection{MATERIALS AND METHODS}

\section{2.] REAGENTS}

Adenosine, 2-chloroadenosine (2-CAdo), $\mathrm{N}^{6}$-cyclopentyladenosine (CPA), erythro-9-(2-hydroxy-3-nonyl)adenine (EHNA), FMLP and LPS (from Escherichia coli, serotype 055:B5, catalog no. L2880) were all obtained from Sigma Chemical (St. Louis, MO). 3,7-dimethyl-1-propargylxanthine (DMPX), 1,3-dipropyl-8-cyclopentylxanthine (DPCPX), $\mathrm{N}^{6}$-(3-iodobenzyl)-adenosine-5'N-methyluronamide (IB-MECA), 8(p-sulfophenyl)theophylline (PST), and xanthine amine congener (XAC) were purchased from Research Biochemicals Incorporated (Natick, MA). The novel AK inhibitor 4-amino-1-(5-amino-5deoxy-1-ß-D-ribofuranosyl)-3-bromo-pyrazolo[3,4-d]pyrimidine (GP515) was kindly provided by Dr. K.M. Mullane (Gensia, Inc., San Diego, CA). Recombinant human TNFa was kindly provided by BASF/Knoll (Ludwigshafen, Germany).

\subsubsection{BLOOD COLLECTION AND WHOLE BLOOD STIMULATION}

Blood, obtained from healthy volunteers after informed consent for research was given, was anticoagulated in evacuated blood collection tubes (Sherwood Medical, St. Louis, MO), containing $0.1 \mathrm{ml} 500 \mathrm{IU} / \mathrm{ml}$ Leo Heparin (Leo Pharmaceutical Products B.V., Weesp, The Netherlands). Whole blood was incubated in polypropylene tubes (Costar, Cambridge, MA) at $37^{\circ} \mathrm{C}$ with reagents as indicated. In experiments where the effects of adenosine or GP515 were tested, $100 \mu \mathrm{M}$ EHNA was added to the cultures to prevent breakdown of adenosine by endogenous adenosine deaminase. After $2 \mathrm{~h}$ incubation, plasma was separated from blood cells by centrifugation for $5 \mathrm{~min}$ at $1500 \times G$, aliquotted, and stored at $-20^{\circ} \mathrm{C}$ until analysis by ELISA.

For determination of purine levels by HPLC, supernatants were deproteinized with $0.4 \mathrm{M}$ perchloric acid on ice, centrifuged at $1200 \mathrm{rpm}$ for 10 min at $4{ }^{\circ} \mathrm{C}$, and neutralized with $0.4 \mathrm{M} \mathrm{K}_{2} \mathrm{HPO}_{4}$. Samples were kept at $-70{ }^{\circ} \mathrm{C}$ until determination of purine levels.

\subsubsection{PMN ISOLATION AND STIMULATION}

PMN were isolated from buffy coats kindly provided by the Red Cross Blood Bank Zuid Limburg (Maastricht, The Netherlands). Blood was donated by healthy volunteers after informed consent for research was obtained. PMN were 
isolated using a standard procedure. In short, blood cells were separated by density gradient centrifugation over Lymphoprep (Nycomed, Oslo, Norway). The interphase containing the mononuclear leukocytes was removed, and the remaining mixture of $\mathrm{PMN}$ and red blood cells was treated for $30 \mathrm{~min}$ with icecold isotonic $\mathrm{NH}_{4} \mathrm{Cl}$ solution ( $155 \mathrm{mM} \mathrm{NH}_{4} \mathrm{Cl}, 10 \mathrm{mM} \mathrm{KHCO}_{3}, 0.1 \mathrm{mM}$ EDTA, $\mathrm{pH}$ 7.4) to lyse the erythrocytes. The remaining PMN were washed twice. The PMN had a purity of more than $98 \%$, and consisted mainly of neutrophils $(>95 \%)$. Isolated PMN $\left(5 \times 10^{6} / \mathrm{ml}\right)$ were resuspended in RPMI-1640, preincubated with $5 \mu \mathrm{g} / \mathrm{ml}$ cytochalasin-B, and subsequently incubated in polypropylene tubes at $37^{\circ} \mathrm{C}$ with reagents as indicated. In experiments where the effects of adenosine or GP515 were tested, $100 \mu \mathrm{M}$ EHNA was added to the cultures to prevent breakdown of adenosine by endogenous adenosine deaminase. After $2 \mathrm{~h}$ incubation, the supernatant was separated from PMN by centrifugation for $5 \mathrm{~min}$ at $1500 \times \mathrm{G}$, and stored at $-20^{\circ} \mathrm{C}$ until analysis by ELISA. Cell viability during the experiment was tested by lactate dehydrogenase release, which was always below $2 \%$ (data not shown).

\subsubsection{REVERSE TRANSCRIPTION PCR OF ADENOSINE A3 RECEPTOR MRNA}

Thirty $\mathrm{ml}$ blood was obtained from healthy donors with heparinized vacutainers. Fresh whole blood was mixed with Hespan (DuPont Pharmaceuticals, Boston, $\mathrm{MA}$ ) in $50 \mathrm{ml}$ conical centrifuge tubes and the erythrocytes were allowed to settle for $30 \mathrm{~min}$. Following sedimentation, the supernatant was layered on a $75 \%$ Percoll gradient (Pharmacia, Uppsala, Sweden) and centrifuged at 2000 $\mathrm{rpm}$ for $50 \mathrm{~min}$ at $4^{\circ} \mathrm{C}$. The neutrophil pellet was resuspended in Heinz-HEPES buffer pH 7.4. The cells were washed briefly in Heinz-HEPES buffer, and lysed with RNASTAT-60 (Tel Test, Friendswood, TX). Total RNA was isolated as per the manufacturers instructions and dissolved in DEPC-treated water. First strand cDNA was synthesized using the RNA PCR Core Kit (Perkin Elmer, Foster City, CA) according to the manufacturers instructions. The amplification primers were as follows: 5'-AACGTGCTGGTCATCTGCGTGGTC-3', and 5'GTAGTCCATTCTCATGACGGAAAC-3'. Primers were synthesized and HPLC-purified by Operon Technologies (Alameda, CA). PCR was performed for 33 cycles and consisted of denaturing at $95^{\circ} \mathrm{C}$ for $30 \mathrm{sec}$, annealing at $56^{\circ} \mathrm{C}$ for $30 \mathrm{sec}$, and extension at $72^{\circ} \mathrm{C}$ for $45 \mathrm{sec}$. PCR products from the A3 receptor reaction were reamplified using nested amplification primers, i.e. the $5^{\prime \prime}$ primer described above, and the additional 3' A3 primer 5'CTGCAGACCACCACCTTCTATTTC-3". PCR conditions were not changed 
for the reamplification. Reaction products were resolved on a $1 \%$ agarose gel, and visualized with ethidium bromide under UV light illumination.

\subsubsection{BPI ELISA}

BPI concentrations were determined using a sandwich-ELISA as described previously (24). In short, 96-well plates (Immuno-Maxisorp; Nunc, Roskilde, Denmark) were coated overnight at $4^{\circ} \mathrm{C}$ with human BPI-specific mAb $4 \mathrm{E} 3$, and free sites were blocked with PBS-1\% BSA. Wash and dilution buffer consisted of $80 \mathrm{mM} \mathrm{MgCl}_{2}, 50 \mathrm{mM}$ TrisHCl pH7.4, $150 \mathrm{mM} \mathrm{NaCl}, 0.1 \%$ BSA, and $0.05 \%$ Tween 20 . The plates were washed 5 times after each incubation step. Human rBPI (a kind gift from Dr. M. Marra, Incyte, Palo Alto, CA) was used for standard titration curves. Test samples, diluted in assay buffer, were added to the plates and incubated for $2 \mathrm{~h}$ at room temperature. Next, $5 \mu \mathrm{g} / \mathrm{ml}$ biotinylated polyclonal rabbit anti-human BPI IgG was added as detection antibody and incubated for $1 \mathrm{~h}$ at room temperature, followed by a 1 -h incubation period with peroxidase-conjugated streptavidin. Finally, the plates were washed with distilled water containing $0.1 \%$ Tween 20 , and $3,3^{\prime}, 5,5^{\prime}-$ tetramethylbenzidine (TMB) was added as substrate for peroxidase. Photospectrometry at $450 \mathrm{~nm}$ was performed using a micro-ELISA autoreader. The detection limit of the assay was $200 \mathrm{pg} / \mathrm{ml}$.

\subsubsection{ELASTASE ELISA}

Human neutrophil elastase (HNE) was detected with a sandwich-ELISA generously provided by Dr. P.S. Hiemstra, Department of Pulmonology, University Hospital Leiden, Leiden, The Netherlands. Briefly, microwells (Immulon 4; Dynatech Laboratories, Chantilly, VA) were coated overnight at room temperature with the IgG fraction of polyclonal rabbit anti-human elastase. HNE standard, purified from purulent sputum (25), as well as test samples were diluted in PBS containing $0.05 \%(\mathrm{v} / \mathrm{v})$ Tween 20 and $1 \%(\mathrm{v} / \mathrm{v})$ heat-inactivated newborn calf serum, and were incubated for $1 \mathrm{~h}$ at $37^{\circ} \mathrm{C}$. Bound elastase was detected using biotinylated rabbit anti-human elastase IgG during a $1 \mathrm{~h}$ incubation period at $37^{\circ} \mathrm{C}$. Next, peroxidase-conjugated streptavidin was incubated for $1 \mathrm{~h}$ at $37^{\circ} \mathrm{C}$, followed by TMB. The lower detection limit of the assay was less than $0.4 \mathrm{ng} / \mathrm{ml}$. Crossreactivity in this ELISA with highly purified preparations of the neutrophil proteinases cathepsin $\mathrm{G}$ and proteinase 3 was less than $0.3 \%$ and $0.01 \%$, respectively (26). 


\subsubsection{DEFENSIN ELISA}

Human defensins HNP 1-3 were determined by ELISA, as originally described by Panyutich et al. (27), with minor modifications. Microtiter plates (Nunc, Denmark) were coated overnight at $4^{\circ} \mathrm{C}$ with $4 \mu \mathrm{g} / \mathrm{ml}$ anti-HNP-1 mAb DI-1 in 0.1 $\mathrm{M} \mathrm{Na}_{2} \mathrm{CO}_{3}$, pH 9.6. After washing the plates with $20 \mathrm{mM}$ Tris-HCl, HNP standard and experimental samples were diluted in $20 \mathrm{mM}$ Tris-HCL, 0.5 M $\mathrm{NaCl}, \mathrm{pH} 7.4$, containing $0.01 \%$ hexadecyltrimethylammonium bromide (TBSCETAB), and incubated for $50 \mathrm{~min}$ at room temperature. Standard titration curves were made in plasma from 10 healthy donors, diluted to the same concentration as the experimental samples. Next, biotin-labeled anti-HNP mAb D1-11, diluted in TBS-CETAB, was added to the wells, and incubated for 40 min at room temperature, followed by a 40 -min incubation period with streptavidin-peroxidase in TBS-CETAB. Finally, the plates were developed with TMB, and photospectrometry was performed at $450 \mathrm{~nm}$.

\subsubsection{STATISTICAL ANALYSIS}

All data are presented as mean \pm SEM. Statistical analysis was performed as indicated by Student $t$-test or by one-way analysis of variance, followed by Bonferroni's $t$-test when overall variation was significant. Differences were considered statistically significant at $p<0.05$.

\subsection{RESULTS}

\subsubsection{EFFECTS OF ADENOSINE ON NEUTROPHIL DEGRANULATION IN STIMULATED WHOLE BLOOD AND BY ISOLATED PMN}

Control levels of BPI, HNE, and HNP in unstimulated whole blood incubated for $2 \mathrm{~h}$, were $8.4 \pm 0.6 \mathrm{ng} / \mathrm{ml}, 150 \pm 20 \mathrm{ng} / \mathrm{ml}$, and $150 \pm 15 \mathrm{ng} / \mathrm{ml}$, respectively (Figure 2.1). Incubation of whole blood with $10 \mathrm{ng} / \mathrm{ml}$ LPS for 2 h resulted in a 5-fold increase of BPI, a 6.5-fold increase of HNE, and a 9-fold increase of HNP compared to control levels. Similarly, stimulation of whole blood with 10 $\mathrm{ng} / \mathrm{ml} \mathrm{TNF} \alpha$ potently induced release of BPI $(55.7 \pm 3.6 \mathrm{ng} / \mathrm{ml})$, HNE $(2,040 \pm$ $360 \mathrm{ng} / \mathrm{ml})$, and HNP $(1,735 \pm 115 \mathrm{ng} / \mathrm{ml})$. LPS and TNF $\alpha$ were used as 
activating agents since they represent physiological stimuli, and have been shown to be very potent and sensitive inducers of BPI and elastase'.

Figure 2.1 Control levels of BPL, HNE, and HNP in unstimulated and stimulated whole blood

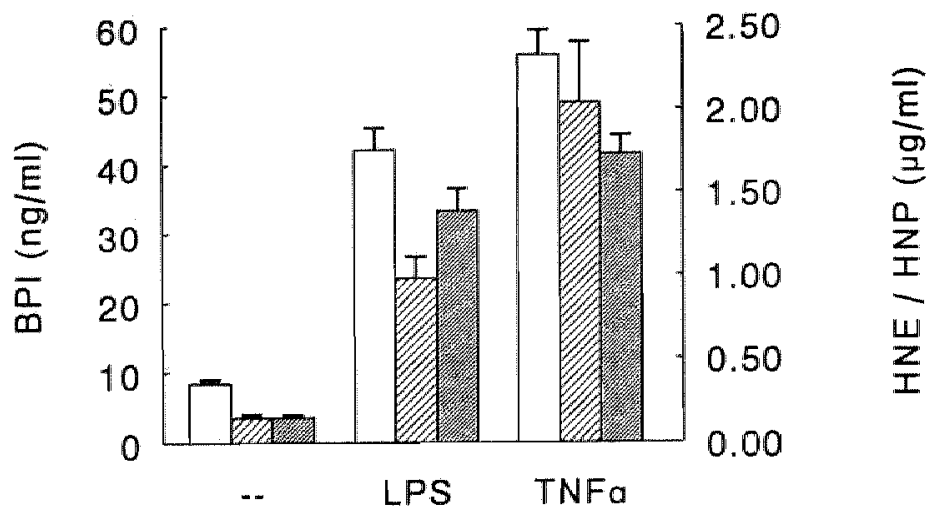

Whole blood was incubated with either $10 \mathrm{ng} / \mathrm{ml}$ LPS or $10 \mathrm{ng} / \mathrm{ml}$ TNF $\alpha$, or without stimuli for $2 \mathrm{~h}$ at $37^{\circ} \mathrm{C}$. At the end of the incubation period, supernatants were collected as described, and BPI (open bars), HNE (hatched bars), and HNP (cross-hatched bars) content were determined by specific ELISA. Results are shown as mean + SEM of four separate experiments.

When LPS- and TNF $\alpha$-stimulated whole blood cultures were coincubated with a concentration range of adenosine, a dose-dependent inhibition of the release of BPI as well as HNE and HNP was observed (Figure 2.2). For both LPS- and TNF $\alpha$-induced BPI, maximum inhibition was approximately $60-70 \%$, whereas maximum inhibition of HNE was about $80 \%$. Release of HNP induced by LPS or TNF $\alpha$ was also attenuated by adenosine in an identical fashion as described for $\mathrm{BPI}$ and HNE. In addition, adenosine dose-dependently inhibited release of BPI, HNE, and HNP by whole blood stimulated with other microbial agents, such as FMLP, and serum-treated zymosan (STZ), to a similar extent (Table 2.1).

'Dentener MA, Francot GJM, Hiemstra PS, Tool ATJ, Verhoeven AJ, Vandenabeele P, Buurman WA. Bactericidal/permeability-increasing protein release in whole blood ex vivo: strong induction by lipopolysaccharide and tumor necrosis factor- $\alpha$. J Infect Dis 175: 108117,1997 . 
Figure 2.2. Adenosine inhibits the release of BPI (O), $H N E(\bullet)$, and HNP ( 4$)$ in stimulared whole blood
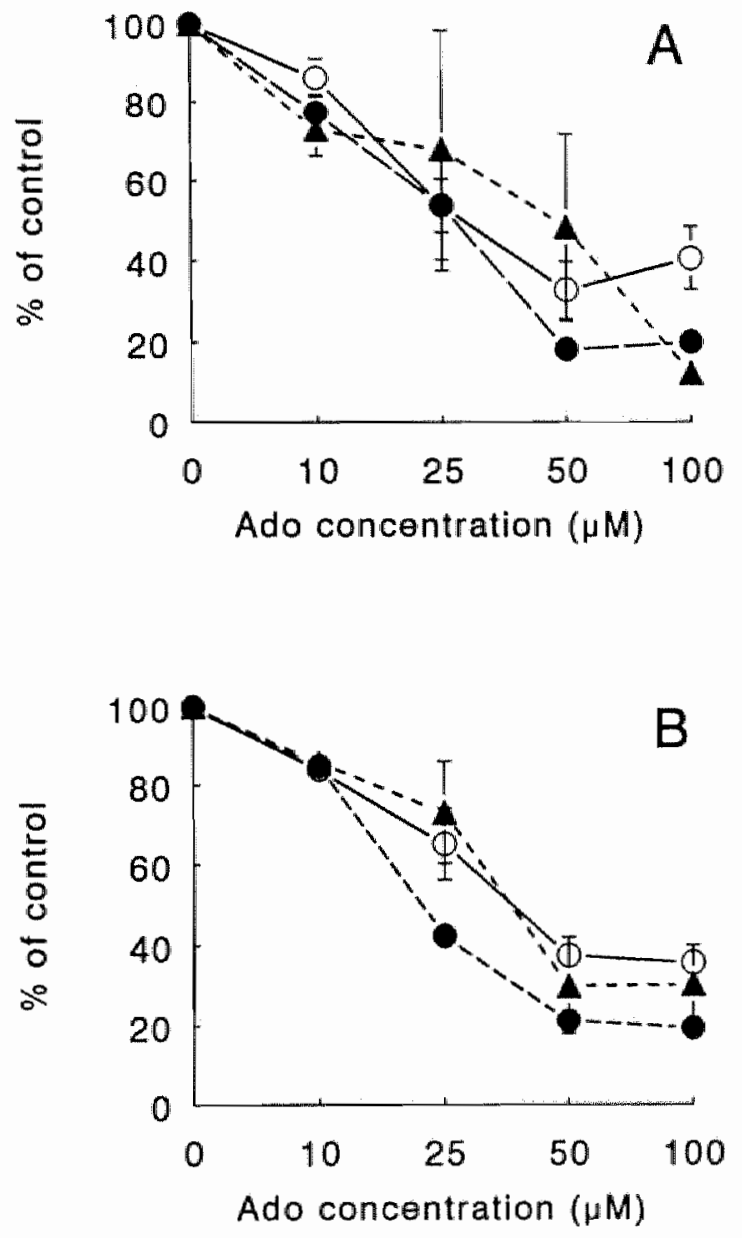

Whole blood was incubated for 2 hat $37^{\circ} \mathrm{C}$ with either $10 \mathrm{ng} / \mathrm{ml} \mathrm{LPS}(A)$, or $10 \mathrm{ng} / \mathrm{ml} \mathrm{TNF} \alpha$ (B) and a concentration range of $0-100 \mu \mathrm{M}$ adenosine (Ado) in the presence of $100 \mu \mathrm{M}$ EHNA. At the end of the incubation period, supernatants were collected as described, and BPI, HNE, and HNP were determined by specific ELISA. Results are shown as mean \pm SEM of four separate experiments. Error bars are omitted if they fall within the symbol. All data presented differed significantly from control cultures incubated without adenosine $(p<0.05$ by Student $t$-test). 
Table 2.1 Inhibury effects of adenosine on release of BPI and HNE in stimulated whole blood ${ }^{7}$

\begin{tabular}{lcccc}
\hline & \multicolumn{2}{c}{ BPI } & \multicolumn{2}{c}{ HNE } \\
Treatment & $\begin{array}{c}\text { Maximum } \\
\text { Inhibition }(\%)^{3}\end{array}$ & $\begin{array}{c}I_{50} \\
(\mu \mathrm{M})^{c}\end{array}$ & $\begin{array}{c}\text { Maximum } \\
\text { Inhibition }(\%)\end{array}$ & $\begin{array}{r}I_{50} \\
(\mu \mathrm{M})\end{array}$ \\
\hline LPS & $72.0 \pm 6.6$ & $20.2 \pm 4.7$ & $75.0 \pm 10.3$ & $14.2 \pm 5.8$ \\
TNF $\alpha$ & $71.5 \pm 3.5$ & $23.6 \pm 5.1$ & $71.0 \pm 7.5$ & $21.2 \pm 2.9$ \\
FMLP & $80.5 \pm 3.3$ & $26.9 \pm 7.5$ & $82.8 \pm 0.7$ & $26.5 \pm 1.8$ \\
STZ & $59.1 \pm 5.6$ & $24.5 \pm 10.6$ & $57.6 \pm 19.3$ & $17.6 \pm 7.5$ \\
\hline
\end{tabular}

"Whole blood was uncubated for 2 h at $37^{\circ} \mathrm{C}$ with either $10 \mathrm{ng} / \mathrm{ml} \mathrm{LPS}, 10 \mathrm{ng} / \mathrm{ml} \mathrm{TNF}$. 0 , $10^{\prime}$ M FMJP, or $100 \mu \mathrm{g} / \mathrm{ml} \mathrm{STZ}$, with or without a concentration range of $1-100 \mu \mathrm{M}$ adenosine in the presence of $100 \mu \mathrm{M}$ EHNA. Results are given as mean \pm SEM of four separate experiments. All data presented differed significantly from stimulated control cultures incubated without adenosine $\left(p<0.05\right.$ by Student $t$-test). ${ }^{\circ}$ Percentage inhibition was calculated as $100 \%$ minus experimental walue as $\%$ of control. " $\mathbb{I} \mathrm{C}_{50}$, i.e. the concentration of adenosine producing $50 \%$ of maximal inhibition, was determined by extrapolation from dose-response curves of four separate experiments.

In comparison, the effects of adenosine on LPS-induced release of BPI and HNE by isolated PMN were determined (Table 2.2, upper panel). At a concentration of $10 \mu \mathrm{M}$ adenosine, release of $\mathrm{HNE}$ by isolated PMN was reduced more potently than in whole blood $(38.6 \pm 2.2 \%$ of control vs. $77.4 \pm$ $4.6 \%$ of control, respectively), whereas inhibition of BPI in whole blood and isolated PMN was not significantly different. At a concentration of $100 \mu \mathrm{M}$ of adenosine however, reduction of BPI as well as HNE was identical in whole blood compared to isolated PMN. Release of BPI and HNE by isolated PMN stimulated with either FMLP, STZ, and PMA was attenuated in a similar fashion as described above for whole blood (data not shown).

\subsubsection{EFFECTS OF ADENOSINE RECEPTOR-SPECIFIC AGONISTS ON NEUTROPHL DEGRANULATION IN WHOLE BLOOD AND BY ISOLATED PMN}

To determine the role of specific adenosine receptors in the observed inhibition of neutrophil degranulation, the effects of the non-metabolizable adenosine analogues CPA, 2-CAdo, and IB-MECA on stimulated release of BPI and HNE in whole blood were compared. CPA is a highly selective Al receptor agonist $(18,28)$, whereas 2 -CAdo binds to $A 1$ and $A 3$ receptors $(18,20)$, and at higher 
micromolar concentrations also exerts A2-mediated effects (6). IB-MECA has recently been described as a highly potent and selective $\mathrm{A} 3$ receptor agonist $i n$ vitro and in vivo $(29,30)$.

Figure 2.3 Effects of adenosine receptor-specific agonists om release of BPI and HNE in stimmilated whole blood
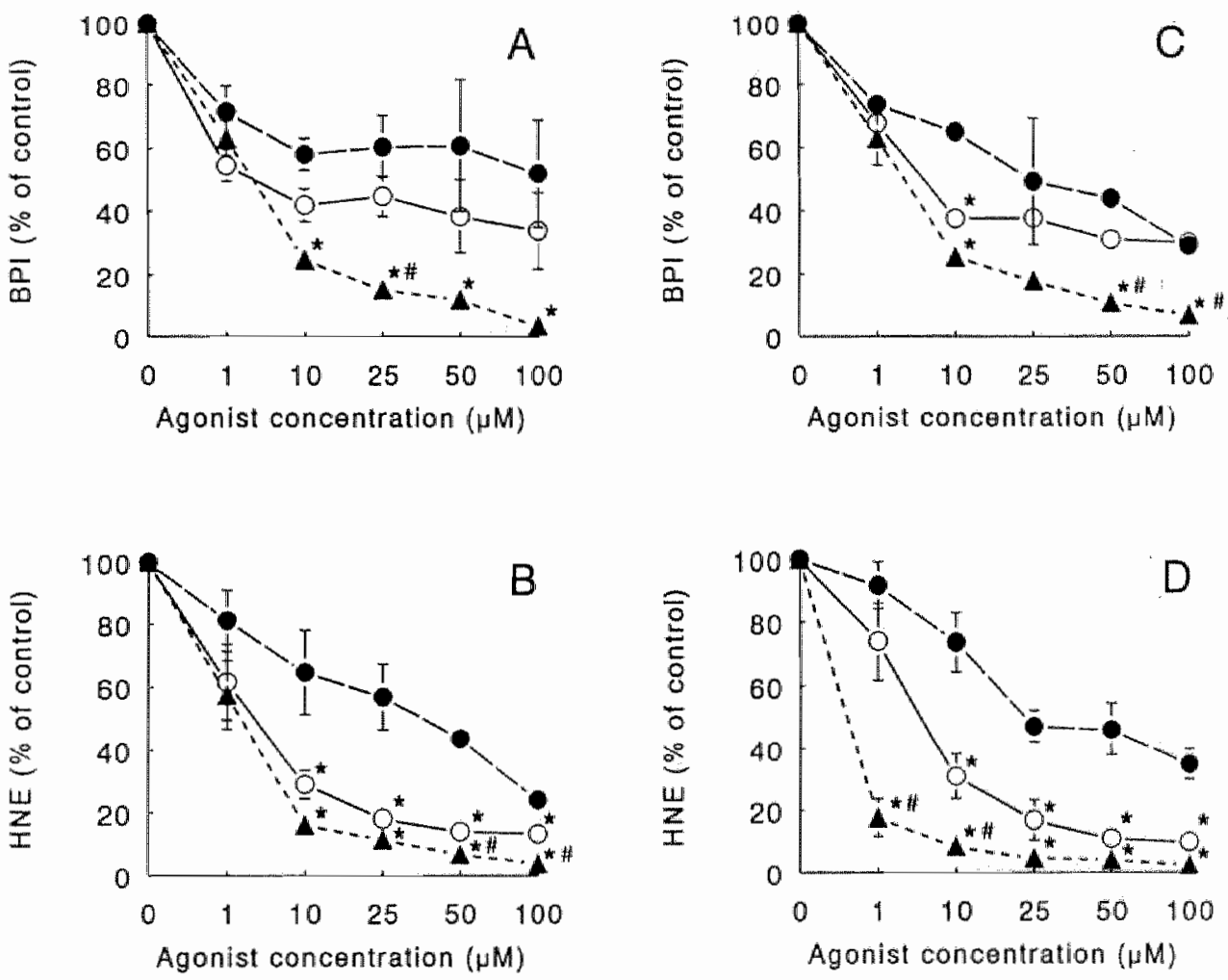

Whole blood was incubated for $2 \mathrm{~h}$ with either $10 \mathrm{ng} / \mathrm{ml}$ LPS $(A$ and $B$ ) or $10 \mathrm{ng} / \mathrm{ml} \mathrm{TNF} \alpha(C$ and $D$ ), and a concentration range of either $1-100 \mu \mathrm{M}$ 2-CAdo (O), CPA ( ), or IB-MECA (^). Results are shown as mean \pm SEM of at least four different experiments. Error bars are omitted if they fall within the symbol. * indicates a statistically significant difference versus CPA, \# indicates a statistically significant difference versus 2 -CAdo $(p<0.05$ by one-way ANOVA). All data presented differed significantly from control cultures incubated without adenosine agonists. 
As illustrated in Figures 2.3A and 2.3B, 2-CAdo attenuated LPS-induced BPI in whole blood somewhat more potently than $\mathrm{CPA}$, although statistical significance was not reached. Except at a $10 \mu \mathrm{M}$ concentration, where 2-CAdo had a significantly stronger inhibitory effect, CPA was also approximately equipotent to 2-CAdo in reducing release of BPI induced by TNF $\alpha$ (Figures $2.3 \mathrm{C}$ and 2.3D). However, at concentrations of $10 \mu \mathrm{M}$ and higher, IB-MECA reduced LPS- as well as TNF $\alpha$-induced BPI significantly stronger than CPA. At these concentrations, IB-MECA also reduced BPI more than 2-CAdo, but significance was not consistently reached. In contrast to the results obtained with stimulated release of BPI, 2-CAdo at concentrations of $10 \mu \mathrm{M}$ and higher was significantly more effective than CPA in inhibiting release of HNE after stimulation with either LPS or TNF $\alpha$ (Figure 2.3).

Table 2.2 Inhibitory effects of adenosine and adenosine receptor-specific agonists on release of BPI and HNE by LPS-stimulated PMN in whole blood and isolated PMN ${ }^{\text {a }}$

whole blood

isolated PMN

BPI HNE BPI HNE

\begin{tabular}{ccccc}
\hline $\begin{array}{c}\text { Adenosine } \\
10 \mu \mathrm{M}\end{array}$ & $86.3 \pm 4.9$ & $77.4 \pm 4.6^{\#}$ & $61.0 \pm 5.2$ & $38.6 \pm 2.2$ \\
$100 \mu \mathrm{M}$ & $40.7 \pm 7.8$ & $20.1 \pm 1.5$ & $33.6 \pm 5.4$ & $28.8 \pm 4.7$ \\
& & & & \\
$2-C A d o$ & & & & \\
$10 \mu \mathrm{M}$ & $42.0 \pm 5.2$ & $29.1 \pm 4.6^{*}$ & $60.1 \pm 6.1^{*}$ & $45.8 \pm 6.9^{*}$ \\
$100 \mu \mathrm{M}$ & $34.0 \pm 12.0$ & $13.5 \pm 1.9^{*}$ & $45.8 \pm 4.3$ & $46.4 \pm 2.5$ \\
$C P A$ & & & & \\
$10 \mu \mathrm{M}$ & $58.2 \pm 5.1^{\sharp}$ & $64.7 \pm 13.4$ & $80.7 \pm 5.9$ & $70.8 \pm 3.6$ \\
$100 \mu \mathrm{M}$ & $52.0 \pm 17.0$ & $24.1 \pm 2.7^{\sharp}$ & $48.8 \pm 10.9$ & $60.4 \pm 5.7$ \\
\hline
\end{tabular}

"Whole blood or cytochalasin-B-pretreated isolated PMN in suspension were incubated for $2 \mathrm{~h}$ at $37^{\circ} \mathrm{C}$ with $10 \mathrm{ng} / \mathrm{ml}$ LPS with either adenosine, 2-CAdo or CPA at the indicated concentrations. Data are presented as $\%$ of release by control cultures stimulated with 10 $\mathrm{ng} / \mathrm{ml}$ LPS without adenosine or receptor-specific agonists. All data presented differed significantly from stimulated control cultures incubated without adenosine or receptorspecific agonists ( $p<0.05$ by Student $t$-test). Results are given as mean \pm SEM of six separate experiments. * indicates a statistically significant difference compared to effect of an equimolar concentration of CPA in the same group $(p<0.05$ by oneway-ANOVA, followed by Bonferroni's $t$-test), \# indicates a statistically significant difference compared with release by isolated PMN $(p<0.05$ by Student $t$-test). 
Similarly, IB-MECA attenuated stimulated HNE release much more potently than CPA. Compared with 2-CAdo, IB-MECA exerted a somewhat more potent inhibitory effect on $\mathrm{HNE}$, but significance was not always reached. However, at concentrations of 1 and $10 \mu \mathrm{M}$, a difference between IB-MECA and 2-CAdo with regard to inhibition of TNF $\alpha$-induced HNE was indeed observed. Release of HNE was maximally reduced to approximately 10 to $15 \%$ of control by 2 CAdo, whereas release of BPI into the same supernatants was reduced maximally to approximately $35 \%$ of control. Maximum inhibition of either BPI or HNE by IB-MECA ranged from 2.5 to $7 \%$ of control. When the effects of CPA and 2-CAdo on LPS-induced BPI and HNE by isolated PMN were compared, a significant difference between the two agonists was observed (Table 2.2). At $10 \mu \mathrm{M}, 2$-CAdo inhibited both BPI and HNE more potently than CPA.

\subsubsection{EFFECTS OF ADENOSINE RECEPTOR-SPECIFIC ANTAGONISTS ON} NEUTROPHIL DEGRANULATION IN STIMULATED WHOLE BLOOD

To further examine the role of specific adenosine receptors, the effects of the A1-selective antagonist DPCPX, the A2-selective antagonist DMPX, the nonselective $A 1 / A 2$ receptor antagonist PST, and the A1/A3 receptor antagonist $\mathrm{XAC}$ on the observed inhibition of neutrophil degranulation by adenosine were determined (Figure 2.4). The inhibitory effects of adenosine on LPS- and TNF $\alpha$-induced release of BPI were partially blocked by the A1/A3 antagonist XAC. Similarly, the A1/A2 antagonist PST partially reversed adenosinemediated inhibition of BPI in whole blood stimulated with LPS (adenosine + PST: $52.5 \pm 3.5 \%$ of control $v$. adenosine alone: $31.2 \pm 4.4 \%$ of control), and TNF $\alpha$ (adenosine + PST: $42.6 \pm 5.5 \%$ of control $v s$. adenosine alone: $30.4 \pm$ $1.7 \%$ of control). Moreover, while the A2-selective antagonist DMPX was equally effective to PST in blocking the effect of adenosine, the A1-selective antagonist DPCPX was completely without effect on adenosine-mediated inhibition of degranulation. Furthermore, the combination of XAC and PST did have an additive blocking effect on adenosine-mediated inhibiton of TNF $\alpha$ stimulated release of BPI (XAC + PST: $67.1 \pm 3.6 \%$ of control vs. XAC alone: $53.3 \pm 4.8 \%$ of control), whereas for LPS-induced BPI no additive effect of the combination of both antagonists compared with either antagonist alone was observed. 
Figure 2.4 Lffects of adenosine receptor-specific antagonists on inhibition of BPI release by adenosine in stimulated whole blood
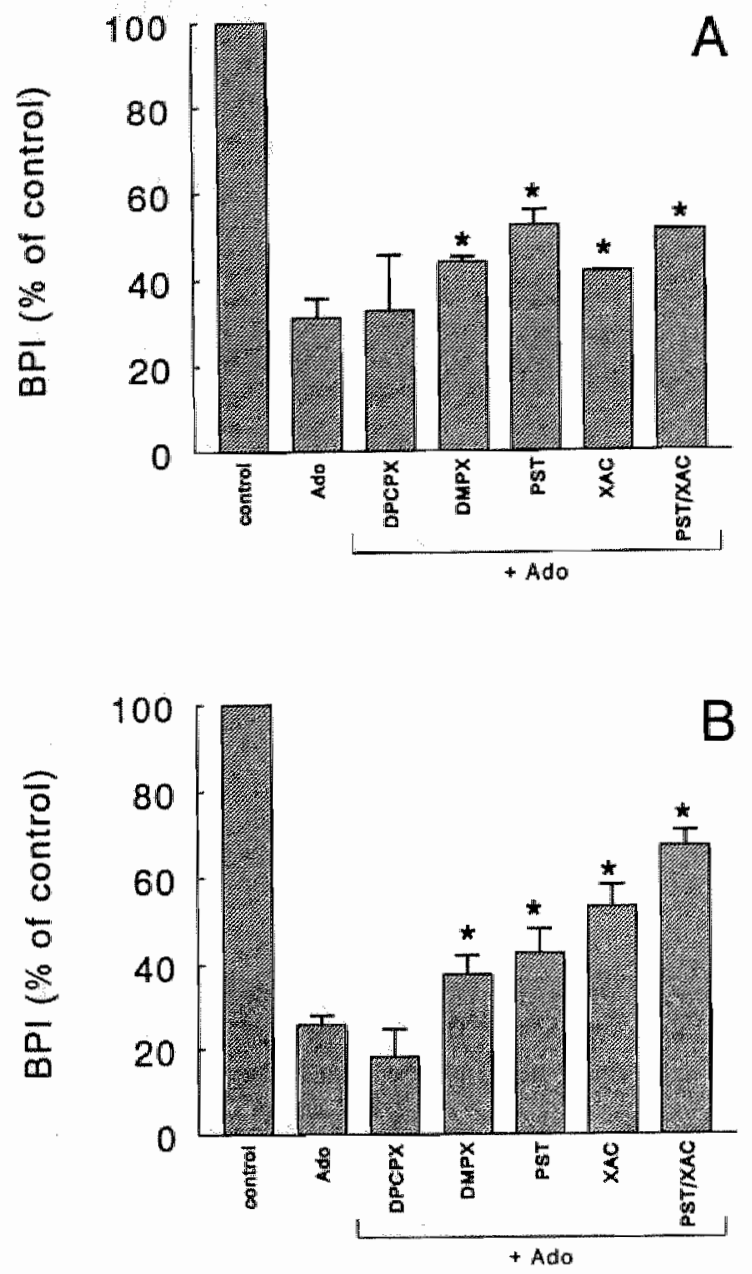

Whole blood was preincubated for 15 min with $50 \mu \mathrm{M}$ of either DPCPX, DMPX, PST, XAC, or a combination of PST and XAC, and subsequently coincubated with $50 \mu \mathrm{M}$ adenosine (Ado) and either $10 \mathrm{ng} / \mathrm{ml} \mathrm{LPS}(A)$, or $10 \mathrm{ng} / \mathrm{ml}$ TNF $\alpha(B)$ for $2 \mathrm{~h}$ at $37^{\circ} \mathrm{C}$. Control cultures were incubated with either LPS or TNF $\alpha$ alone. Results are shown as mean + SEM of three separate experiments with duplicate determinations. indicates a statistically significant difference $(p<0.05$ by Student $t$-test) compared with stimulated cultures incubated with adenosine without antagonists. 
Figure 2.5 Effects of adenosine receptor-specific antagonists on inhibition of BPI release by 2-CAdo and IB-MECA in stimulated whole blood
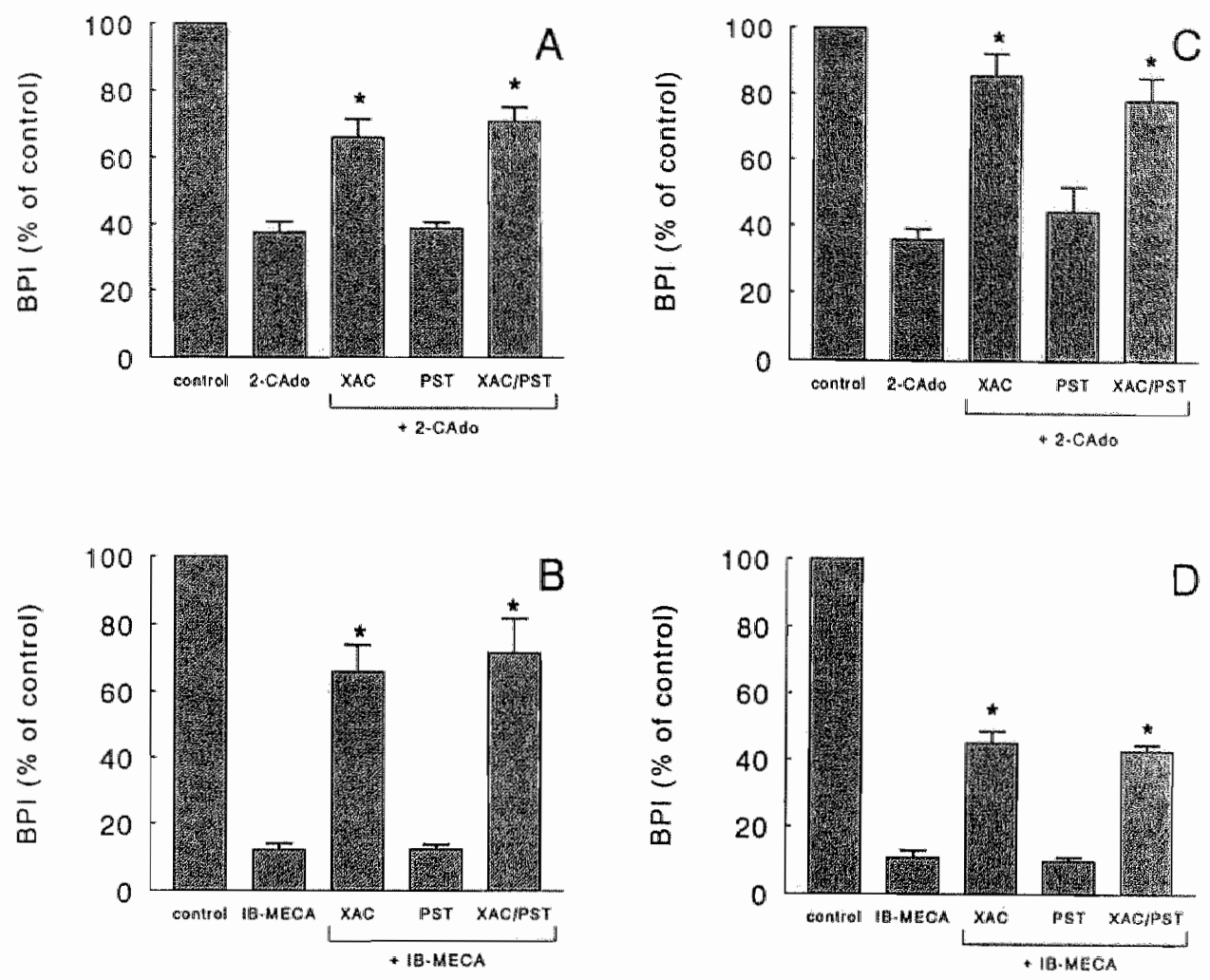

Whole blood was preincubated for 15 min with $50 \mu \mathrm{M}$ of either PST, XAC, or a combination of both antagonists, and subsequently coincubated with either $50 \mu \mathrm{M}$ 2-CAdo or IB-MECA and either $10 \mathrm{ng} / \mathrm{ml}$ LPS $(A$ and $B)$, or $10 \mathrm{ng} / \mathrm{ml}$ TNF $\alpha(C$ and $D)$ for $2 \mathrm{~h}$ at $37^{\circ} \mathrm{C}$. Control cultures were incubated with either LPS or TNF $\alpha$ alone. Results are shown as mean + SEM of three separate experiments with duplicate determinations. ${ }^{*}$ indicates a statistically significant difference $(p<0.05$ by Student $i$-test) compared with stimulated cultures incubated with 2 CAdo or IB-MECA without antagonists. 
Next; the effects of PST and XAC on 2-CAdo- and IB-MECA-mediated inhibition of degranulation were assessed (Figure 2.5). The inhibitory effect of 2-CAdo on release of BPI in LPS-activated whole blood was largely abrogated by XAC (2-CAdo + XAC: $65.9 \pm 5.3 \%$ of control vs. 2-CAdo alone: $37.3 \pm$ $3.3 \%$ of control), and 2-CAdo-mediated inhibition of TNF $\alpha$-induced BPI was almost completely reversed by XAC (2-CAdo + XAC: $85.6 \pm 6.5 \%$ of control ws. 2-CAdo alone: $35.7 \pm 3.2 \%$ of control). In contrast, PST did not affect the suppression of either LPS- or TNF $\alpha$-induced release of BPI by 2-CAdo. In line with this, the combination of XAC and PST reversed the effects of 2-CAdo to a similar extent as XAC alone. Similar results were obtained with IB-MECAmediated inhibition of stimulated BPI release, where XAC strongly antagonized its effect, whereas PST, either alone or combined with XAC, was completely without effect. The actions of PST and XAC on inhibition of HNE release by 2CAdo and IB-MECA, were identical to those described here for release of BPI (data not shown).

Figure 2.6 Presence of A3 receptor message in human neutrophils

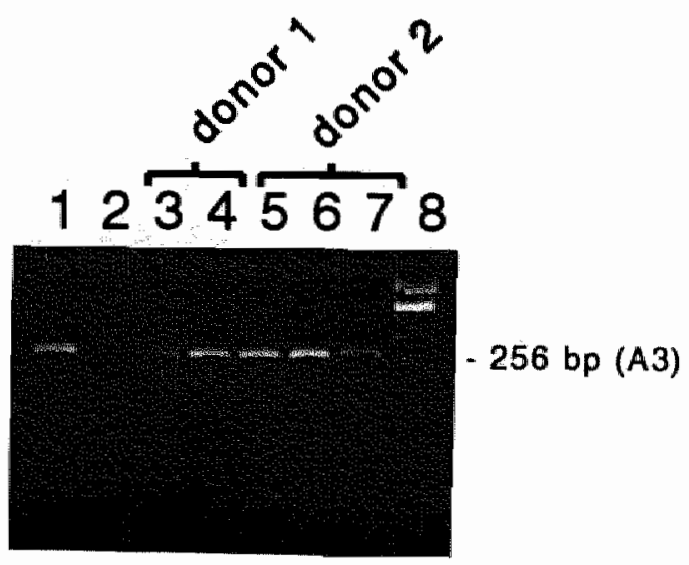

Neutrophils from two different donors were isolated, and PCR analysis was performed as described in Materials and Methods. Some neutrophil suspensions were treated with $10^{-7} \mathrm{M}$ FMLP for 10 min prior to PCR analysis. Lane 1 : A3 cDNA control plasmid. Lane 2: negative control (PCR without template). Lane 3: $4 \times 10^{6}$ resting PMN. Lane 4: $4 \times 10^{6}$ FMLPstimulated PMN. Lane 5: $4 \times 10^{6}$ FMLP-stimulated PMN. Lane 6: $8 \times 10^{6}$ FMLP-sitimulated PMN. Lane $7: 8 \times 10^{6}$ resting PMN. Lane 8: Size marker. 
The finding that 2-CAdo and IB-MECA exert potent inhibitory effects on neutrophil degranulation, combined with the reversal of these effects by the $\mathrm{A} 1 / \mathrm{A} 3$ antagonist $\mathrm{XAC}$, strongly suggested the involvement of an $\mathrm{A} 3$ receptor on neutrophils in these observations. However, the presence of A3 receptors on human neutrophils had thus far not been demonstrated. Therefore, nonquantitative RT-PCR of A3 receptor mRNA was performed in human neutrophils, and confirmed that $\mathrm{A} 3$ receptor message was indeed present in these cells (Figure 2.6).

\subsubsection{EFFECTS OF THE AK-INHIBITOR GP5 15}

To evaluate the relevance of the results described above to the potential therapeutic benefits of adenosine-regulating agents, the effect of GP515 on neutrophil degranulation in the ex vivo whole blood model was tested. GP515 is a novel AK inhibitor, that has been proven effective in animal models of endotoxic (17) and hemorrhagic shock ${ }^{2}$. Coincubation of LPS- or TNF $\alpha-$ stimulated whole blood with a concentration range of 1 to $100 \mu \mathrm{M}$ GP5 15 dosedependently reduced release of BPI (Figure 2.7) and HNE (not shown), maximally to approximately $50 \%$ of control. To confirm that GP5 15 increased endogenous adenosine levels, adenosine concentrations in the culture supernatants were determined by HPLC. While in LPS-stimulated whole blood incubated without GP515 $2.5 \pm 0.4 \mu \mathrm{M}$ endogenous adenosine was present, coincubation of LPS-stimulated whole blood with $100 \mu \mathrm{M}$ GP515 enhanced endogenous adenosine levels significantly to $12.5 \pm 0.7 \mu \mathrm{M}$ (Figure 2.8). Similarly, GP515 elevated adenosine concentrations in unstimulated whole blood to a comparable level of $13.6 \pm 0.5 \mu \mathrm{M}$ (data not shown). To confirm that inhibition of degranulation by GP515 was indeed mediated by endogenous adenosine, the effects of coincubation with the adenosine receptor antagonists DMPX and XAC were determined. As depicted in Figure 2.9, the inhibitory actions of GP515 on LPS-induced BPI and HNE were significantly reduced by XAC, whereas DMPX had a mild, but significant, antagonizing effect on GP515-mediated inhibition of BPI, but not of HNE.

${ }^{2}$ Bauer C, Bouma MG, Herrmann I, Van den Wildenberg FAJM, Firestein GS, Marzi I, Buurman WA. The adenosine kinase inhibitor GP515 attenuates leukocyte-endothelial interactions in the liver after hemorrhagic shock and resuscitation in the rat. Am J Physiol (Gastrointest Liver Physiol): In press. 
Figure 2.7 Effect of the AK inhibitor GP5/5 on release of BPI in stimulated whole blood

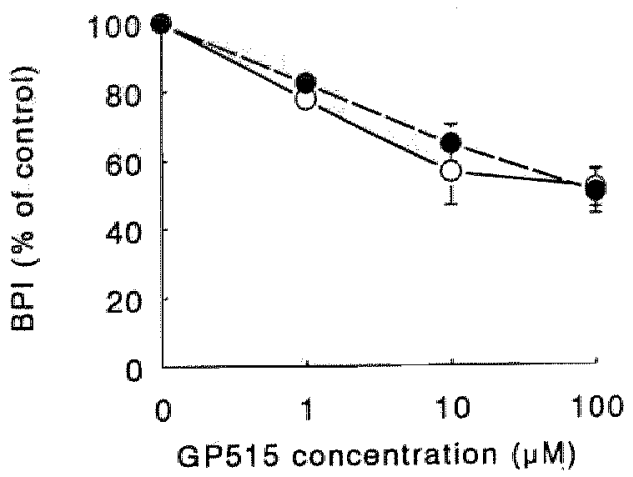

Whole blood was incubated with either $10 \mathrm{ng} / \mathrm{ml}$ LPS (o) or $10 \mathrm{ng} / \mathrm{ml}$ TNF-a (e), and a concentration range of $1-100 \mu \mathrm{M}$ GP515 in the presence of $100 \mu \mathrm{M} \mathrm{EHNA}$ for $2 \mathrm{~h}$ at $37^{\circ} \mathrm{C}$. At the end of the incubation period, supernatants were collected, and BPI concentrations were determined by specific ELISA. Results are shown as mean \pm SEM of three experiments with duplicate determinations. Error bars are omitted if they fall within the symbol. All data presented differed significantly from stimulated control cultures incubated without GP5 15 $(p<0.05$ by Student $l-$ test $)$.

Figure 2.8 Effect of the AK inhibitor GP515 on purine levels in LPS-stimulated whole blood

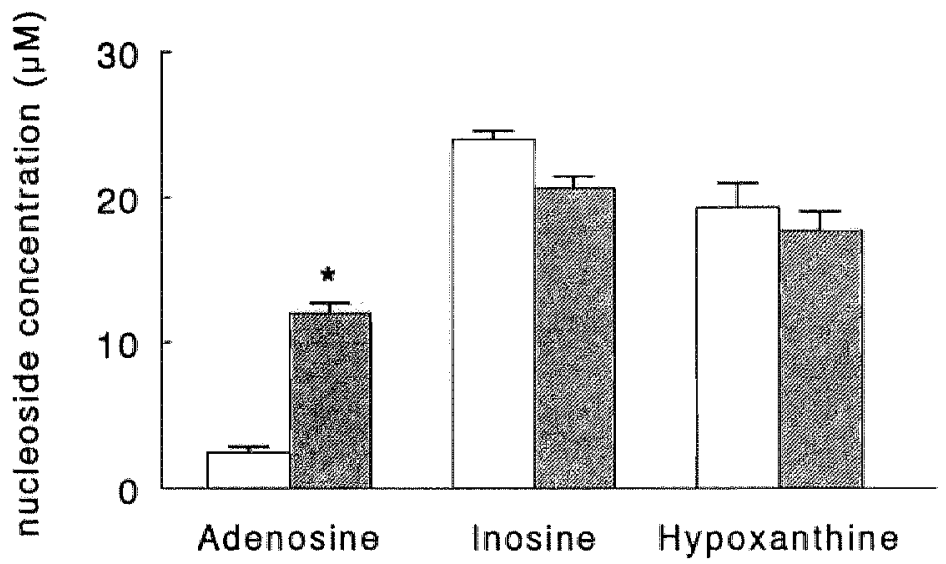

Whole blood was stimulated with $10 \mathrm{ng} / \mathrm{ml} \mathrm{LPS}$ either without (open bars) or with $100 \mu \mathrm{M}$ GP515 (hatched bars) in the presence of $100 \mu \mathrm{M}$ EHNA for $2 \mathrm{~h}$ at $37^{\circ} \mathrm{C}$. At the end of the incubation period, plasma samples were processed as described in Materials and Methods, and purine levels were determined by HPLC. Results are shown as mean + SEM of four different donors. * indicates a statistically significant difference compared with stimulated cultures incubated without GP5 15 ( $p<0.05$ by Student $t$-test). 
Figure 2.9 Effects of adenosine receptor-spectfic antagonists on inmibition of release of BPl (A) and HNE (B) by GPSIS in LPS-stimwlated whole blood
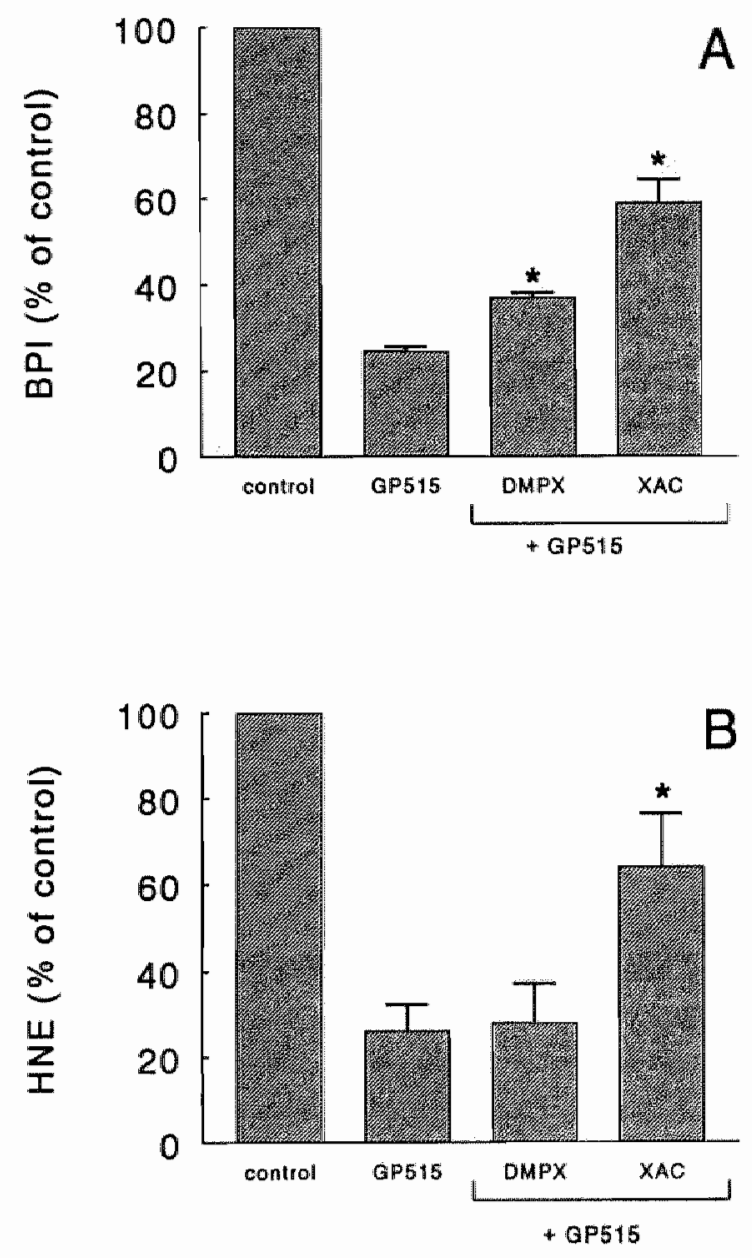

Whole blood was preincubated for 15 min with $50 \mu \mathrm{M}$ of either DMPX or XAC, and subsequently coincubated with $100 \mu \mathrm{M}$ GPS15 in the presence of $100 \mu \mathrm{M}$ EHNA, and 10 $\mathrm{ng} / \mathrm{ml}$ LPS for $2 \mathrm{~h}$ at $37^{\circ} \mathrm{C}$. Control cultures were incubated with LPS allone. Results are shown as mean + SEM of three separate experiments with duplicate determinations. * inclicates a statistically significant difference $(p<0.05$ by Student $t$-test $)$ compared with stimulated cultures incubated with GPS 15 without antagonists. 


\subsection{Discussion}

While there is a large body of evidence to show that adenosine, acting via A2 receptors, is a potent inhibitor of the neutrophil respiratory burst $(4,9,21,22)$, its reported effects on degranulation by isolated neutrophils, either adherent or in suspension, have been contradictory. Therefore, the present study was undertaken to investigate the effects of adenosine and its receptor-specific analogues on the release of neutrophil granule constituents in an ex vivo human whole blood system. As parameters of neutrophil degranulation, the release of the azurophil granule constituents BPI, HNE, and HNP in response to LPS and TNF $\alpha$ was determined.

Here, we demonstrate that adenosine dose-dependently inhibited neutrophil degranulation in human whole blood activated with either LPS or TNF $\alpha$, and that it attenuated the release of each of the three azurophil granule proteins determined to approximately the same extent. Furthermore, the inhibitory effect of adenosine was of a comparable magnitude for two other inflammatory agents tested, i.e. FMLP and $\mathrm{STZ}$, with $\mathrm{IC}_{50}$ ranging from approximately 15 to $25 \mu \mathrm{M}$. Our observation that degranulation, induced by agents that activate different signal transduction pathways, was inhibited by adenosine to a similar extent, suggests a final common inhibitory pathway. The reported stimulus-specificity for modulation of neutrophil oxygen free radical generation (23) may therefore not apply to neutrophil degranulation. In relation to this it must be noted that, in the present study and in that of McGarrity et al. (23), the concentrations of adenosine required to inhibit degranulation, are higher than those that effectively attenuate respiratory burst, which is consistent with reported differences in threshold effects of CAMP involved in regulation of neutrophil enzyme release and superoxide production (31).

The reported lack of effect of adenosine on degranulation by isolated PMN in previous in vitro studies $(21-23)$ has been attributed to the use of cytochalasin-B to enhance secretion from neutrophils in suspension (32). On the other hand, it has been suggested that adherence of neutrophils to biological surfaces might be a prerequisite for the inhibitory actions of adenosine on both respiratory burst (33) as well as degranulation (32). We therefore selected LPS and TNF $\alpha$ as activating agents in our whole blood experiments, since they are very potent and selective inducers of azurophilic granule release in whole blood, without the requirement for cytochalasin-B or adherence as additional triggering signals, as was recently demonstrated by our group ${ }^{\text {(see footnote } 1)}$. However, in the present study, comparison of the inhibitory effects of adenosine on degranulation in whole blood and isolated, cytochalasin-B-pretreated PMN 
in suspension, revealed no major differences. Likewise, the efficacy of 2-CAdo to reduce degranulation was largely identical in whole blood and isolated PMN. Thus, our data do not support the hypothesis that adherence or the use of cytochalasin-B is of critical importance when assessing the effects of adenosine or its analogues on neutrophil degranulation. In line with our observations, others have also demonstrated inhibitory effects of adenosine (34) and 2-CAdo (35) on exocytotic release of granule constituents in the presence of cytochalasin- $\mathrm{B}$. The reason for these conflicting results with cytochalasin-B treated PMN is not clear, but may be related to other factors, such as PMN isolation procedure, agonist concentration, length of incubation, or intrinsic differences in PMN responsiveness.

The results obtained with the adenosine receptor-specific agonists and antagonists suggest that inhibition of degranulation is partly dependent on A2receptor activation as well as on $A 3$ receptor activation. The latter conclusion is based on the observation that IB-MECA, a highly selective A3 agonist, as well as 2-CAdo, an agonist that binds to all of the adenosine receptor subtypes and has the greatest affinity for $A 1$ and $A 3$ receptors $(18,20)$, reduced degranulation, particularly of $\mathrm{HNE}$, significantly stronger than $\mathrm{CPA}$, a highly selective A1-receptor agonist. Moreover, the mixed A1/A3 antagonist XAC strongly reduced $\mathrm{IB}-\mathrm{MECA}$ - as well as 2-CAdo-mediated inhibition of LPSand TNF $\alpha$-induced degranulation, whereas the non-selective A1/A2 antagonist PST did not affect the inhibitory actions of both agonists on degranulation. Together, these observations, combined with the demonstrated presence of $A 3$ receptor message in human $\mathrm{PMN}$, strongly suggest the involvement of $\mathrm{A} 3$ receptor activation in suppression of neutrophil degranulation. However, A2 receptor ligation also seems to be involved in this process, because the inhibitory effects of adenosine were partially reversed by the highly A2 receptor-specific antagonist DMPX, and the $A 1 / A 2$ receptor antagonist PST. Moreover, the highly selective Al antagonist DPCPX was completely without effect on adenosine-mediated inhibition of degranulation. In line with the suggested role for $\mathrm{A} 3$ receptors, XAC also partially blocked the actions of adenosine.

The observed involvement of $A 2$ receptors in the inhibition of degranulation is consistent with the known A2 receptor-mediated actions of adenosine on neutrophil superoxide generation and adhesion $(4,6-10)$. A2 receptors are thought to couple unifocally to adenylate cyclase, with activation resulting in enhanced generation of intracellular cAMP (36). Enhancement of cAMP is therefore regarded as a major effector system of the anti-inflammatory actions of adenosine, although it is unlikely to be the sole mechanism by which its 
inhibitory effects on neutrophill function are exerted $(22,37,38)$. The reported inhibitory effects of cAMP-raising agents on neutrophil degranulation in vitro (32), and in vivo (39) support our observation that A2 receptors are, at least in part, involved in attenuation of degranulation.

The involvement of $\mathrm{A} 3$ receptor ligation in inhibition of human neutrophil degranulation, as observed in the present study, is in sharp contrast with reports that $A 3$ receptor activation facilitates degranulation of mast cells in the rat ( 40 , 41). Although the cell types are different, we have currently no explanation for these opposing effects of $A 3$ receptor activation on degranulation between both species. In this context however, it is of importance to note that the A3 receptor exhibits unusually large differences in structure, tissue distribution and pharmacological properties between species (41), which severely hampers the extrapolation of the properties of this receptor between species. In line with this, Sajjadi et al. (42), describing an alternatively spliced rat A3 receptor variant, for which no human homologue could be identified, stated that the relevance of non-human models to human A3 function should be viewed with caution. The suggested intracellular mechanisms involved in A3 receptormediated responses in the rat include activation of phospholipase $\mathrm{C}$ with elevation of calcium and inositol 1,4,5-triphosphate levels (43), and generation of nitric oxide with subsequent elevation of cGMP (44). In contrast, in human macrophages $\mathrm{A} 3$-mediated inhibition of $\mathrm{TNF} \alpha$ expression has recently been shown to be independent of phosholipase $\mathrm{C}$ activation (20), indeed illustrating the functional diversity of A3 receptors between species. Therefore, the underlying mechanisms involved in A3 receptor-mediated inhibition of human neutrophil degranulation have yet to be defined.

The results obtained with the AK inhibitor GP515 point to a further therapeutical benefit of this agent, and possibly other adenosine-regulating agents, in inflammatory disorders. The strategy underlying the use of adenosineregulating agents is to increase endogenous adenosine levels at sites of inflammation, thus enhancing the beneficial effects of adenosine. Indeed, GP515 significantly enhanced endogenous adenosine levels in unstimulated and stimulated whole blood in this study, while previous studies have indicated that GP515 augments release of adenosine from resting endothelial cells in vitro (6), and enhances adenosine concentrations in cell free exudates in a murine air pouch model, using carrageenan as pro-inflammatory stimulant (45). While GP515 did augment the concentration of endogenous adenosine, the corresponding level of inhibition of degranulation was higher than the degree of inhibition obtained with a similar concentration of exogenous adenosine. However, since it has been postulated that endogenous adenosine modulates 
cellular function by interacting with its receptors in an autocrine or paracrine manner (36), it is conceivable that lower concentrations of endogenous adenosine, compared with the amount of exogenously added adenosine, are required to obtain a similar degree of inhibition. The observation that the inhibitory effects of GP515 were antagonized by adenosine receptor antagonists, further supports the contention that its effects are indeed mediated by endogenous adenosine.

In conclusion, we report here that adenosine at micromolar concentrations and the AK inhibitor GP515 inhibit ex vivo human neutrophil degranulation, partly via A2- and A3 receptor-mediated mechanisms. As mentioned earlier, release of preformed granule-stored proteins is an important feature of neutrophil activation, contributing to neutrophil-mediated tissue injury in a variety of infectious and inflammatory conditions. Next to the inhibitory effects of adenosine on cytokine release $(16,17,46,47)$, expression of endothelial adhesion molecules $(47)$, neutrophil adhesion $(6,7,10)$ and superoxide anion generation $(9,21)$, these findings may therefore represent an additional mechanism by which adenosine exerts its anti-inflammatory actions, and add to the therapeutic potential of adenosine-regulating agents towards neutrophilmediated tissue injury in inflammatory conditions, such as sepsis and ischemiareperfusion.

\section{ACKNOWLEDGEMENT}

This study was supported in part by a grant from INTAS (grant no. 94-1634). The authors are grateful to Dr. R.A. De Abreu, Department of Pediatrics, Academic Hospital Nijmegen St. Radboud, Nijmegen, The Netherlands, for determination of purine levels in the culture supernatants.

\section{REFERENCES}

1. Henson PM, Henson JE, Fittschen C, Bratton DL, Riches DWH. Degranulation and secretior by phagocytic cells. In Inflammation: Basic principles and clinical correlates. Gallin JI, Goldstein IM, Snyderman R (Eds.), Raven Press Ltd., New York, pp. 511-539, 1992.

2. Bone RC. The pathogenesis of sepsis. Ann Intern Med 115: 457-469, 1991.

3. Welbourn CRB, Goldman G, Paterson IS, Valeri CR, Shepro D, Flechtman HB. Pathophysiology of ischaemia-reperfusion injury: central role of the neutrophil. $\mathrm{Br} J$ Surg 78: 651-655, 1991 . 
4. Cronstein BN, Kubersky SM, Weissmann G; Hirschorn R. Engagement of adenosine receptors inhibits hydrogen peroxide $\left(\mathrm{H}_{2} \mathrm{O}_{2}\right)$ release by activated human neutrophils. Clin Immunol fmmunopathol 42:76-85, 1987.

5. Cronstein BN, Eberle MA, Gruber $\mathrm{HE}_{\mathrm{y}}$ Levin $\mathrm{RI}$. Methotrexate inhibits neutrophil function by stmulating adenosine release from connective tissue cells. Proc Natl Acad Sci USA 88: 2441-2445, 1991.

6. Firestein $\mathrm{GS}$, Bullough $\mathrm{DA}$, Erion $\mathrm{MD}$, Jimenez $\mathrm{R}$, Ramirez-Weinhouse $\mathrm{M}$, Barankiewicz J , Smith CW, Gruber HE, Mullane KM. Inhibition of neutrophil adhesion by adenosine and an adenosine kinase inhibitor. The role of selectins. $J$ Immunol 154 : 326-334, 1995 .

7. Bullough DA, Magill MJ, Firestein GS, Mullane KM. Adenosine activates $A_{2}$ receptors to imhibit neutrophil adhesion and injury to isolated cardiac myocytes. J Immunol 155 : $2579-2586,1995$.

8. Cronstein BN, Levin RI, Belanoff $J$, Weissmann $G$, Hirschhorn $R$. Adenosine: an endogenous inhibitor of neutrophil-mediated injury to endothelial cells. I Clin Imvest 78 : 760-777, 1986.

9. Cronstein $B N$, Rosenstern ED, Kramer SB, Weissmann $G$, Hirschhorn R. Adenosine, a physiological modulator of superoxide anion generation by human neutrophils: adenosine acts via an $A_{2}$ receptor on human neutrophils. J Immunol 135: 1366-1371, 1985.

10. Cronstein BN, Levin RI, Phillips M, Hirschhorn R, Abramson SB, Weissmann G. Neutrophil adherence to endothelium is enhanced via adenosine $A_{\|}$receptors and inhibited via adenosine $\mathrm{A}_{2}$ receptors. J Immunol 148: 2201-2206, 1992.

11. Newby AC. Adenosine and the concept of retaliatory metabolites. Trends Biochem Sci 9 : $42-44,1984$.

12. Mullane K, Bullough D, Shapiro D. From academic vision to clinical reality. A case study of acadesine. Trends Cardiovasc Med 3:227-234, 1993.

13. Gruber HE, Hoffer ME, McAllister DR, Laikind PK, Lane TA, Schmid-Schoenbein GW, Engler RL. Increased adenosine concentration in blood from ischemic myocardium by AICA riboside. Effects on flow, granulocytes, and injury. Circulation 80: 1400-1411, 1989.

14. Vinten-Johansen J, Nakanishi K, Zhao ZQ, MoGee DS, Tan P. Acadesine improves surgical myocardial protection with blood cardioplegia in ischemically injured canine hearts. Circularion 88: 350-358, 1993.

15. Sandhu GS, Burrier AC, Janero DR. Adenosine deaminase inhibitors attenuate ischemic injury and preserve energy balance in isolated guinea pig heart. Am $J$ Physiol 265: H1249-H1256, 1993.

16. Parmely MJ, Zhou WW, Edwards III CK, Borcherding DR, Silverstein R, Morrison DC. Adenosine and a related carbocyclic nucleoside analogue selectively inhibit tumor necrosis factor- $\alpha$ production and protect mice against endotoxin challenge. $J$ Immunol $151: 389-396,1993$.

17. Firestein GS, Boyle D, Bullough DA, Gruber HE, Sajjadi FG, Montag A, Sambol B, Mullane KM. Protective effect of an adenosine kinase inhibitor in septic shock. $J$ Jmmunol 152: 5853-5859, 1994.

18. Collis MG, Hourani SM. Adenosine receptor subtypes. Trends Pharmacol Sci 14: 360$366,1993$. 
19. Cronstein BN, Daguma L, Nichols D, Hutchison AJ, Williams $M$, The adenosine/neutrophil paradox resolved: human neutrophils possess both $\mathrm{A} 1$ and $\mathrm{A} 2$ receptors that promote chemotaxis and inhibit 02 -generation, respectively. $J \mathrm{Clin}$ Imvest 85: 1150-1157, 1990.

20. Sajjadi FG, Takabayashi K, Foster AC, Domingo RC, Firestein GS. Inhibition of TNF- $\alpha$ expression by adenosine. Role of A3 adenosine receptors. I Immuol 156: 3435-3442, 1996.

21. Cronstein BN. Kramer SB, Weissmann G, Hirschhorn R. Adenosine: a physiological modulator of superoxide anion generation by human neutrophils. $J \operatorname{Exp~Med~158:~} 1160$ $1177,1983$.

22. Cronstein BN, Kramer SB, Rosenstein ED, Korchak HM, Weissmann G, Hirschhorn R. Occupancy of adenosine receptors raises cyclic AMP alone and in synergy with occupancy of chemoattractant receptors and inhibits membrane depolarization. Biochem I252: 709-715, 1988 .

23. McGarrity ST, Stephenson AH, Webster RO. Regulation of human neutrophil functions by adenine nucleotides. J Immunol 142: 1986-1994, 1989.

24. Dentener MA, Francot GIM, Smit FT, Froon AHM, Pennings HJ , Wouters EFM, Buurman WA. Presence of bactericidal/permeability-increasing protein in disease: detection by ELISA. I Infect Dis 171: 739-743, 1995.

25. Feinstein G, Janoff A. A rapid method of purification of human granulocyte cationic neutral proteases: purification and further characterization of human granulocyte elastase. Biochim Biophys Acta 403: 493-505, 1975.

26. De Backer WA, Amsel B, Jorens PG, Bossaert L, Hiemstra PS, Van Noort P, Van Overveld FJ. $\mathrm{N}$-acetylcysteine pretreatment of cardiac surgery patients influences plasma neutrophil elastase and neutrophil influx in bronchoalveolar lavage fluid. Intens Care Med 22: 900-908, 1996.

27. Panyutich AV, Voitenok NN, Lehrer RI, Ganz T. An enzyme immunoassay for human defensins. J Immunol Methods 141: 149-155, 1991.

28. Jacobson KA, Van Galen PJM, Williams M. Adenosine receptors: pharmacology, structure-activity relationships, and therapeutic potential. I Med Chem 35: 407-422, 1992.

29. Gallo-Rodriguez C, Ji XD, Melman N, Siegman BD, Sanders LH, Orlina J, Fischer B, Pu QL, Olah ME, Van Galen PJM, Stiles GL, Jacobson KA. Structure-activity relationships of $\mathrm{N}^{6}$-benzyladenosine-5-uronamides as $\mathrm{A} 3$-selective adenosine agonists. $J$ Med Chem 37: 636-346, 1994.

30. Jacobson KA, Nikodijevic O, Shi D, Gallo-Rodriguez C, Olah ME, Stiles GL, Daly JW. A role for central A3-adenosine receptors. Mediation of behavioral depressant effects. FEBS Lett 336: 57-60, 1993.

31. Lad PM, Goldberg BJ, Smiley PA, Olson CV. Receptor-specific threshold effects of cyclic AMP are involved in the regulation of enzyme release and superoxide production from human neutrophils. Biochim Biophys Acta 846:286-295, 1985.

32. Richter $J$, Effect of adenosine analogues and cAMP-raising agents on TNF-, GM-CSF-, and chemotactic peptide-induced degranulation in single adherent neutrophils. $J$ Leukocyte Biol 51: 270-275, 1992. 
33. De la Harpe J, Nathan $\mathrm{CF}$. Adenosine regulates the respiratory burst of cytokinetriggered human neutrophils adherent to biologic surfaces. I Immunol 143: 596-602, 1989.

34. Zhang Y, Fredholm BB. Propentofylline enhancement of the actions of adenosine on neutrophil leukocytes. Biochem Pharmacol 48: 2025-2032, 1994.

35. Schrier DJ , Imre KM. The effects of adenosine agonists on human neutrophil function. $J$ Jmmunol 1 37: 3284-3289, 1986.

36. Stiles GL. Adenosine receptors. I Biol Chem 267: 6451-6454, 1992.

37. Burkey TH, Webster RO. Adenosine inhibits fMLP-stimulated adherence and superoxide anion generation by human neutrophills at an early step in signal transduction. Biochem Biophys Acta 1175: 312-318, 1993.

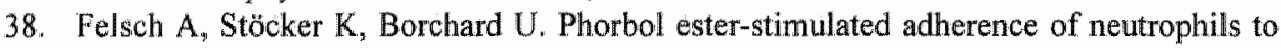
endothelial cells is reduced by adenosine $\mathrm{A}_{2}$ receptor agonists. $J$ Immunol $155: 333-338$, 1995.

39. Van Leenen $D$, Van der Poll $T$, Levi $M$, Ten Cate $H$, Van Deventer $S J H$, Hack $C E$, Aarden LA, Ten Cate JW. Pentoxifylline attenuates neutrophil activation in experimental endotoxemia in chimpanzees. I Immunol 151: 2318-2325, 1993.

40. Fozard JL, Pfannkuche HJ, Schuurman H. Mast cell degranulation following adenosine A, receptor activation in rats. Eur J Pharmacol 298: 293-297, 1996.

41. Linden J. Cloned adenosine A3 receptors: pharmacological properties, species differences and receptor functions. Trends Pharmacol Sci 15:298-306, 1994.

42. Sajjadi FG, Boyle DL, Domingo RC, Firestein GS. cDNA cloning and characterization of $\mathrm{A} 3 \mathrm{i}$, an alternatively spliced rat $\mathrm{A} 3$ adenosine receptor variant. FEBS Lett 382 : 125 $129,1996$.

43. Ramkumar V, Stiles GL, Beaven MA, Ali H. The A3 adenosine receptor is the unique adenosine receptor which facilitates release of allergic mediators in mast cells. $J$ Biol Chem 268: 16887-16890, 1993.

44. Miller $\mathrm{KJ}$, Hoffman $\mathrm{BJ}$. Adenosine $\mathrm{A}_{3}$ receptors regulate serotonin transport via nitric oxide and cGMP. $J$ Biol Chem 269: 27351-27356, 1994.

45. Cronstein BN, Naime D, Firestein GS. The antiinflammatory effects of an adenosine kinase inhibitor are mediated by adenosine. Arthritis Rheum 38: 1040-1045, 1995.

46. Bouma MG, Stad RK, Van den Wildenberg FAJM, Buurman WA. Differential regulatory effects of adenosine on cytokine release by activated human monocytes. $J$ Immunol 1.53:4159-4168, 1994.

47. Bouma MG, Van den Wildenberg FAJM, Butuman WA. Adenosine inhibits cytokine release and expression of adhesion molecules by activated human endothelial cells. $A m$ I Physiol 270: C522-C529, 1996. 
CHAPTER 3

Differential Regulatory Effects of Adenosine on Cytokine Release by Activated Human Monocytes

Bouma MG, Stad RK, Van den Wildenberg FAJM, Buurman WA Journal of Immunology 153: 4159-4168, 1994 


\section{ABSTRACT}

Adenosine is an endogenous nucleoside that can modulate the function of cells involved in the inflammatory response, such as polymorphonuclear granulocytes (PMN) and monocytes. Production and release of cytokines by activated mononuclear phagocytes is an important event in the pathogenesis of ischemia-reperfusion injury, a pathological phenomenon that is associated with excessive ATP-catabolism and subsequent local release of adenosine. The "retaliatory metabolite" adenosine has been shown to interfere with PMN function, thereby attenuating the deleterious consequences of ischemia and reperfusion. In this study we demonstrate that adenosine inhibits the production of TNF $\alpha$, IL- 6 and IL-8 by LPS-activated human monocytes with a differential potency. The A2 receptor-specific adenosine analogues 2-chloroadenosine (2$\mathrm{CAdo}$ ) and $5 \mathrm{~N}$-ethylcarboxamidoadenosine (NECA) were most effective in attenuating LPS-induced cytokine production, while the Al-selective adenosine analogue $\mathrm{N}^{6}$-cyclopentyladenosine (CPA) was less effective, indicating that inhibition of cytokine production by adenosine is primarily an $A 2$ receptormediated event. The observed inhibitory effects were not restricted to endotoxin-induced cytokine production, since adenosine also inhibited TNF $\alpha$ production by monocytes stimulated with the proinflammatory cytokine IL-1 $\beta$. Again, 2-CAdo and NECA reduced IL- $\beta$-induced TNF $\alpha$ production more potently than CPA. In contrast, adenosine enhanced production of IL-6 and IL-8 by monocytes stimulated with IL-1 $\beta$. Furthermore, only 2-CAdo, but not NECA, strongly inhibited cytokine-induced IL-6 and IL-8 production. These results suggest an additional A2 receptor-mediated mechanism of "retaliatory" action of adenosine under pathological conditions, where cytokine production by activated mononuclear phagocytes is involved, such as ischemia-reperfusion injury and septic shock.

\subsection{INTRODUCTION}

Adenosine is a purine nucleoside, that is released extracellularly under normal circumstances at submicromolar concentrations after intracellular degradation of ATP (1). However, under conditions of metabolic stress, such as ischemia, a rapid and massive depletion of intracellular ATP occurs, eventually leading to accumulation of AMP, which in turn is degraded to adenosine. During ischemia and subsequent reperfusion, adenosine and its physiologically inactive metabolites inosine and hypoxanthine, are released locally in the micromolar 
concentration range (2-4). Through binding to specific receptors (5), adenosine exerts many modulating effects on various physiological systems, such as the cardiovascular system and the immune system $(6,7)$.

The most prominent cardiovascular action of adenosine is its vasodilating effect, presumably mediated by binding to $\mathrm{A} 2$ receptors on vascullar smooth muscle, thereby increasing local blood flow in various tissues like heart, brain and skeletal muscle, during ischemia or enhanced physical activity $(7,8)$. Due to this beneficial effect of adenosine under metabolically unfavorable circumstances, which induce its formation by excessive ATP catabolism, it has been termed a "retaliatory metabolite" (9).

The known immunomodulatory actions of adenosine in inflammatory processes are to a large extent mediated through its effects on leukocyte function. Adenosine inhibits, through occupancy of A2 receptors, superoxide anion generation by activated $\mathrm{PMN}$ in vitro (10-12). Furthermore, adenosine and the adenosine analogue 3-deazaadenosine have been shown to interfere with adherence of PMN to the vascular endothelium (13-16), a crucial event in acute inflammatory processes. There is evidence that inhibition of leukocyteendothelium interaction also occurs via A2 receptor activation (15). In contrast, occupancy of the adenosine Al receptor has been shown to promote neutrophil chemotaxis $(1,17)$, and adherence to endothelium or gelatin-coated surfaces (18), thereby exerting a pro-inflammatory effect. Finally, it was reported recently that adenosine in the micromolar range acting via $A 2$ receptors inhibits upregulation of CD1 1 b/CD18 expression on FMLP-stimulated neutrophils (19). By virtue of its vasodilating action as well as its A2 receptor-mediated antiinflammatory effects on PMN, the key mediators of tissue injury in acute inflammatory conditions, adenosine has been recognized as an important: endogenous substance that protects against the deleterious consequences of ischemia-reperfusion $(13,20-23)$.

In analogy to the described actions of adenosine on PMN function, similar modulatory effects on the phagocytic function of mononuclear phagocytes have been described. Ligation of Al receptors by picomolar concentrations of adenosine is pro-inflammatory as a result of enhanced $\mathrm{FC} \gamma$ receptor-mediated phagocytosis, whereas A2 receptor ligation by adenosine at micromolar concentrations inhibits $\mathrm{Fc} \gamma$ receptor-mediated phagocytosis, providing an antiinflammatory effect (24).

Secretion of inflammatory mediators, such as cytokines, is another important function of mononuclear phagocytes, that plays an essential regulatory role in inflammatory responses. Production and release of cytokines by endotoxinactivated mononuclear phagocytes is an important event in the development of 
septic shock $(25,26)$. Furthermore, secretion of cytokines by activated mononuclear phagocytes has been implicated in the pathogenesis of ischemiareperfusion injury, both in in vitro and in vivo experimentall models (27-36). Given the concept of an adenosine-mediated general immunoregulatory feedback mechanism, as mentioned above, we hypothesized that adenosine might be an endogenous modulator of cytokine production and release by activated monocytes. Indeed, this hypothesis was supported by data recently reported by Parmely et al. (37), who found that adenosine selectively inhibits TNF $\alpha$ release by LPS-activated mouse peritoneal macrophages and mouse macrophage-like cell lines in vitro. The present study was undertaken to investigate the effects of adenosine on production and release of TNF $\alpha, I_{-}-6$ and IL- 8 by activated human monocytes in vitro, and to assess the role of specific adenosine receptors in this context.

\subsection{MATERIALS AND METHODS}

\subsubsection{REAGENTS}

Adenosine, 2-chloroadenosine (2-CAdo), 2'-deoxyadenosine, CPA, NECA, and LPS (from Escherichia Coli, serotype 055:LB5, catalog nr. L-2880) were all obtained from Sigma Chemicals, Inc. (St. Louis, MO). Deoxycoformycin (CN81,565, lot nr. R) was from Warner-Lambert Comp. (Ann Arbor, MI). R 88021 (Draflazine), the active $\mathbb{L}$-enantiomer of the nucleoside transport inhibitor $\mathrm{R}$ 75231, was kindly provided by Janssen Pharmaceutica (Beerse, Belgium). Recombinant human TNF $\alpha$ was kindly provided by BASF/Knoll (Ludwigshafen, Germany). Recombinant human IL-1 $\beta$ was a kind gift of Dr. S. Gillis (Immunex, Seattle, WA). RPMI 1640 was obtained from Gibco (Paisley, UK). BCS, purchased from Hyclone (Logan, UT), was heat-inactivated for 30 minutes at $56^{\circ} \mathrm{C}$ and stored at $4{ }^{\circ} \mathrm{C}$.

\subsubsection{CELL ISOLATION AND STIMULATION}

Buffy coats were kindly provided by the Red Cross Blood Bank Zuid Limburg, Maastricht, The Netherlands. Blood was donated by healthy volunteers, after informed consent for research was obtained. Human monocytes were isolated from buffy coats, essentially according to the method described by Graziano et al. (38). Briefly, mononuclear cell suspensions obtained after density gradient centrifugation on Lymphoprep (Nycomed, Oslo, Norway) were allowed to 
clump by low speed centrifugation at $4{ }^{\circ} \mathrm{C}$. Cell clumps, consisting for $80-$ $95 \%$ of monocytes, were separated by sedimentation through ice-cold BCS resulting in cell suspensions consisting of more than $85 \%$ of monocytes. Monocytes were resuspended in RPMI 1640 supplemented with $10 \% \mathrm{BCS}$, $2 \mathrm{mM} \mathrm{L}$-glutamine, $100 \mathrm{IU} / \mathrm{ml}$ penicillin and $100 \mu \mathrm{g} / \mathrm{ml}$ streptomycin, plated on 24-well tissue culture plates (Costar, Cambridge, MA) at $1 \times 10^{6}$ cells per well to an end-volume of $1 \mathrm{ml}$ and incubated at $37^{\circ} \mathrm{C}$. The cells were stimulated with either LPS $(10 \mathrm{ng} / \mathrm{ml})$, or $\mathrm{rhLL}-1 \beta(100 \mathrm{U} / \mathrm{ml})$ for the indicated time periods, in the presence of adenosine or its analogues as indicated, after which the supernatants were harvested and stored at $-20^{\circ} \mathrm{C}$ until use in ELISA. In each experiment, the incubations with the various concentrations of adenosine or its analogues were performed at least in triplicate macrowells per concentration used. In experiments designed to investigate the effects of nucleoside transport inhibition, monocytes were preincubated with a concentration range of $R 88021$ for 5 minutes at $37{ }^{\circ} \mathrm{C}$ and subsequently coincubated with the reagents as described above. Viability of the cells, as measured by trypan blue exclusion, was not significantly affected by any of the reagents used (data not shown).

\subsubsection{CYTOKINE-ASSAYS}

Cytokine concentrations in culture supernatants were determined using previously described sandwich-ELISA's for TNF $\alpha$ (39), IL-6 (40), and a newly developed ELISA for IL-8. In short, 96-well Immuno Maxisorp plates (Nunc, Roskilde, Danmark) were coated overnight at $4{ }^{\circ} \mathrm{C}$ with cytokine-specific murine $\mathrm{mAb} 61 \mathrm{E71}$ (anti-TNF $\alpha$ ), 5E1 (anti-IL-6) and a newly developed IL-8specific murine mAb, designated HM5 (IgG) $)$. Recombinant hTNF $\alpha$, rhIL -6 and rhIL-8 were used for standard titration curves. Test samples were added and incubated for 2 to $3 \mathrm{~h}$ at room temperature. Each experimental sample was assayed at least in duplicate. Polyclonal rabbit anti-human TNF $\alpha$, anti-human IL-6 and biotinylated polyclonal rabbit anti-human IL-8 antibodies were incubated at room temperature for $1 \mathrm{~h}$, followed by a $1 \mathrm{~h}$ incubation with peroxidase-conjugated goat anti-rabbit $\operatorname{IgG}$ (Jackson, West Grove, PA) for TNF $\alpha$ and IL-6, and peroxidase-labelled streptavidin for IL-8. Finally, 3, 3',5, 5'-tetramethylbenzidine (Kirkegaard \& Perry Laboratories, Inc., Gaithersburg, $\mathrm{MD}$ ) was added as a substrate. The reaction was stopped after 15 minutes with $1 \mathrm{M} \mathrm{H}_{2} \mathrm{SO}_{4}$ and photospectrometry was performed at $450 \mathrm{~nm}$. The lower detection limits of the ELISA's were $1 \mathrm{pg} / \mathrm{ml}$ for TNF $\alpha, 10 \mathrm{pg} / \mathrm{ml}$ for $\mathrm{IL}-6$ and 5 $\mathrm{pg} / \mathrm{ml}$ for IL-8. 
To excludle the possibility that the presence of adenosine or its tested analogues interfered with detection of cytokines in the ELISA's, cytokine-containing control samples were diluted in PBS- $0.1 \%$ BSA with a $100 \mu \mathrm{M}$ concentration of adenosine or analogues, and cytokine recovery as compared to control samples diluted in PBS-0.1\% BSA was determined. No interference with cytokine detection occurred in any of the ELISA's used (data not shown).

\subsubsection{STATISTICAL ANALYSIS}

All data are presented as mean values \pm SEM. Differences between the various treatments were tested by one-way analysis of variance, followed by Bonferroni's $t$-test when overall variation was significant. Differences were considered statistically significant at $p<0.05$.

\subsection{RESULTS}

\subsubsection{EFFECTS OF ADENOSINE ON LPS-INDUCED CYTOKINE RELEASE}

Stimulation of monocytes with a concentration range of LPS for $6 \mathrm{~h}$ resulted in a concentration-dependent release of TNF $\alpha$, IL-6 and IL-8. Coincubation with adenosine inhibited LPS-induced TNF $\alpha$, IL-6 and IL-8 release in a dosedependent manner (Figure 3.1 and Figure 3.2). During stimulation with 10 $\mathrm{ng} / \mathrm{ml} \mathrm{LPS}$, the inhibitory activity of adenosine was most pronounced on TNF $\alpha-$ release, with maximum inhibition of $85 \%$ (Table 3.1). Release of IL-6 and IL-8 was inhibited to a lesser extent with maximum inhibition of $67 \%$ and $43 \%$, respectively. While $\mathrm{IC}_{50}$, i.e. the concentration of adenosine producing $50 \%$ of maximal inhibition, was $3 \mu \mathrm{M}$ for TNF $\alpha, \mathrm{IC}_{50}$ for IL-6 and IL-8 were 11 and 40 $\mu \mathrm{M}$, respectively, indicating a differential susceptibility to the inhibitory action of adenosine. The inhibitory effect was dependent on the LPS-concentration used, since even stronger inhibitory effects were seen on cytokine release by monocytes stimulated with $1 \mathrm{ng} / \mathrm{ml} \mathrm{LPS}$, with an almost complete abolishment of TNF $\alpha$.

To determine whether the effect of adenosine was sustained over a longer period of time, monocytes were stimulated with LPS in the presence of adenosine during a $24 \mathrm{~h}$ incubation period. As shown in Figure 3.3, reduction of cytokine release was maintained throughout the $24 \mathrm{~h}$ incubation period, indicating that adenosine does not delay cytokine release, but actually attenuates the release of cytokines. 
Figure 3.1 Adenosine inhibits TNFa (A), $L L-6$ (B), and $I L-8$ release (C) by LPS-stimulated human monocytes
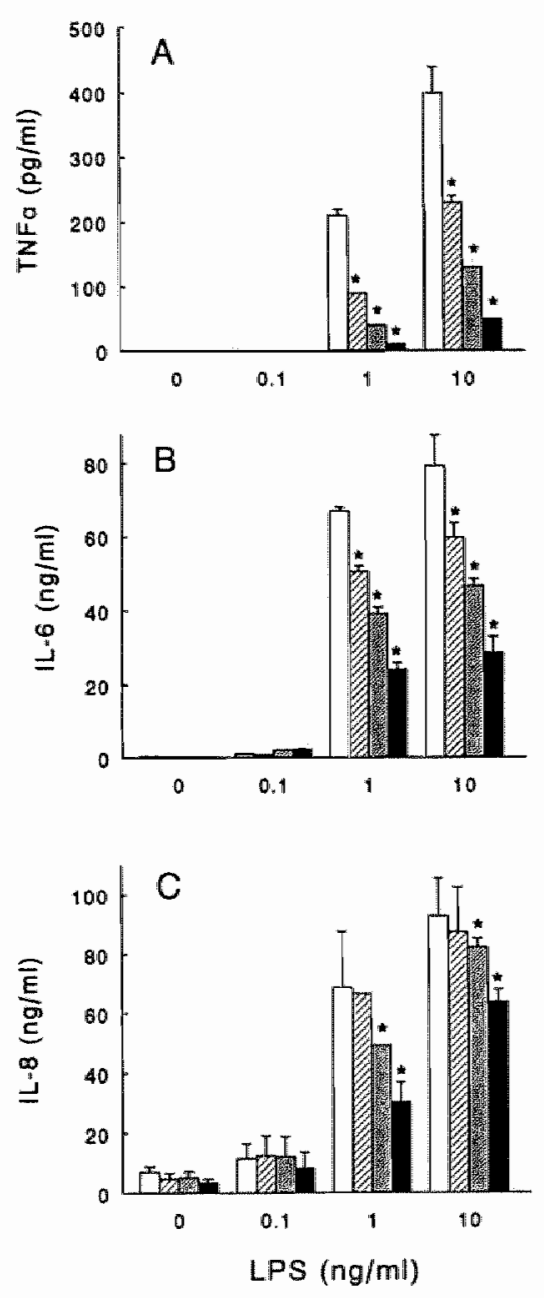

Monocytes were stimulated with a concentration range of LPS in the absence (open bars) or presence of 1 (hatched bars), 10 (double-hatched bars) or $100 \mu \mathrm{M}$ (solid bars) adenosine. After a $6 \mathrm{~h}$ incubation period, the supernatants were collected and cytokine release was determined by ELISA. The results of one experiment, representative of four experiments, are shown. Data are expressed as mean + SEM of four determinations. Error bars are omitted if they fall within the bars. * indicates a statistically significant difference compared to controls. 
Figure 3.2 Inhibition of LPS-induced cytokine release by adenosine and receptor-specific adenosine analogues
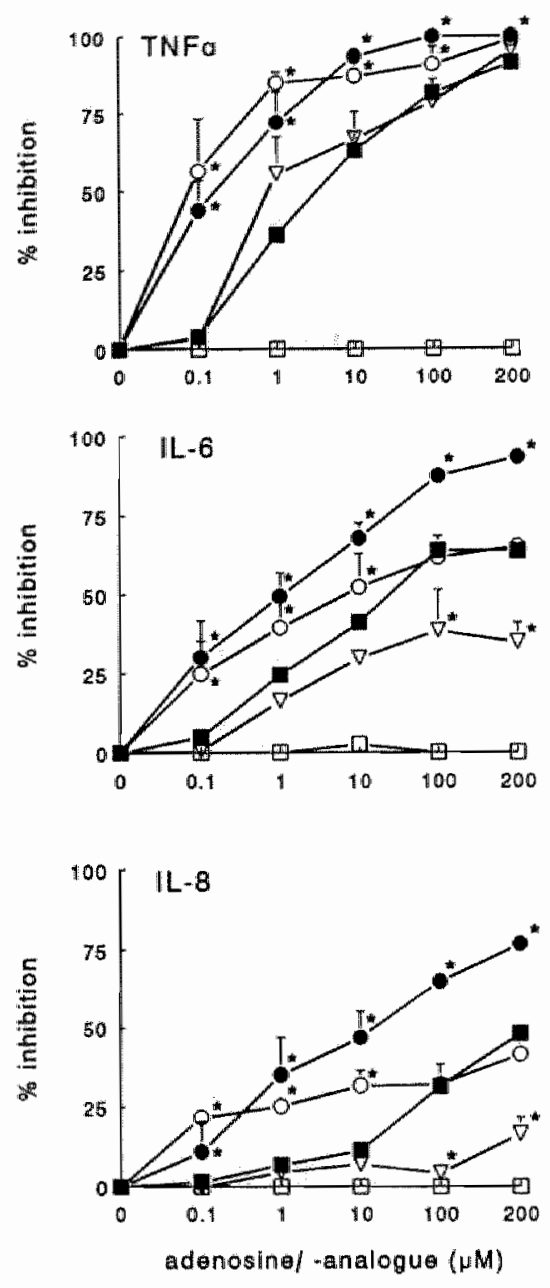

Monocytes were incubated with LPS $(10 \mathrm{ng} / \mathrm{ml})$ and a concentration range of either adenosine (a), NECA (O), 2-CAdo (O), CPA ( 8 ) or 2'-deoxyadenosine ( $\square$ ) for $6 \mathrm{~h}$. Control cultures were incubated with LPS alone. The supernatants were collected and cytokine release was determined by ELISA. Control cytokine levels were $507 \pm 46 \mathrm{pg} / \mathrm{ml}$ for TNF $\alpha, 139.3 \pm 27.8$ $\mathrm{ng} / \mathrm{ml}$ for $\mathrm{IL}-6$, and $181.4 \pm 25.9 \mathrm{ng} / \mathrm{ml}$ for IL-8. Percentage inhibition was calculated as $100 \%$ $-\%$ of control. Results are shown as mean + SEM of four cultures. Error bars are omitted if they fall within the symbol. * indicates a statistically significant difference compared to adenosine. 
Figure 3.3 Inhibition of LPS-induced TNFa (A), $L L-6(B)$ and $L-8(C)$ by adenosine is maintained throughout a $24 \mathrm{~h}$ incubation period
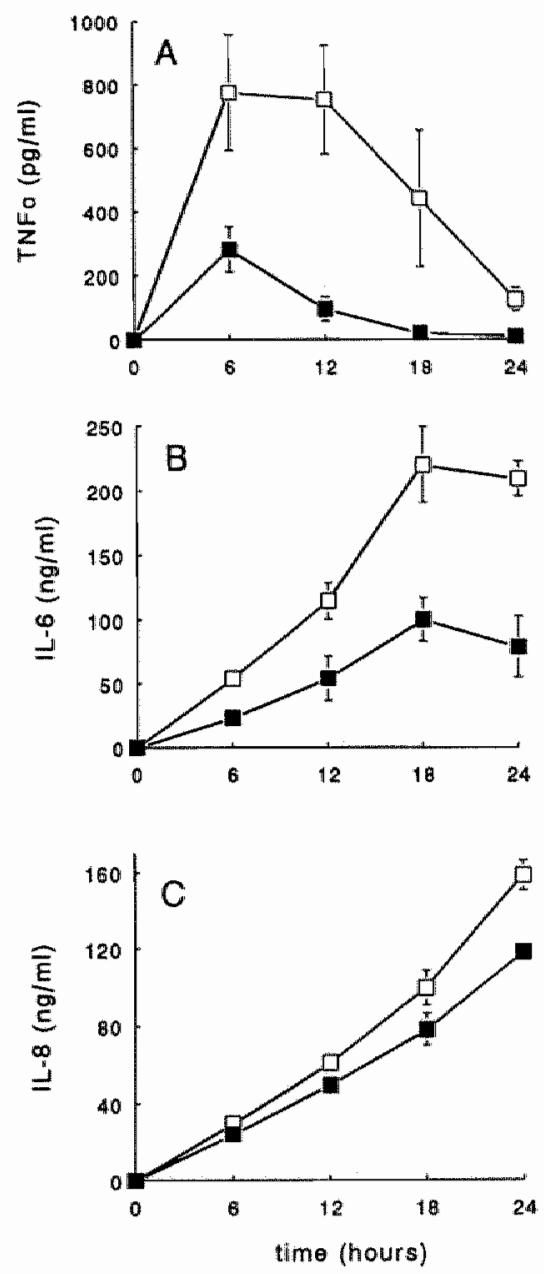

Monocytes were incubated with LPS $(10 \mathrm{ng} / \mathrm{ml})$ in the absence $(\square)$ or presence of $100 \mu \mathrm{M}$ adenosine (四) for $24 \mathrm{~h}$. At the indicated timepoints supernatants were collected and cytokine release was determined by specific ELISA. The results of one experiment, representative of three, are shown. Data are expressed as mean \pm SEM of triplicate determinations. Error bars are omitted if they fall within the symbol. 
Table 3.1 Inhibitory effects of adenosine on cytokine release by monocytes stimulated with $L P S^{\text {iz }}$

\begin{tabular}{lcc}
\hline cylokine & max.inhibition $(\%)^{\phi}$ & $\mathrm{IC}_{\text {si }}(\mu \mathrm{M})^{\circ}$ \\
\hline TNF $\alpha$ & $85.1 \pm 2.8$ & $3.3 \pm 2.3$ \\
IJ 6 & $67.2 \pm 7.4$ & $11.3 \pm 9.6$ \\
IL -8 & $43.3 \pm 6.1$ & $40.0 \pm 15.3$ \\
\hline
\end{tabular}

Monocytes were stimulated with LPS $(10 \mathrm{ng} / \mathrm{ml})$ in the absence (control) or presence of adenosine $(0.1-200 \mu \mathrm{M})$. The supernatant was collected after an incubation period of $6 \mathrm{~h}$ and release of TNF $\alpha_{2}$ JL-6 and IL-8 was determined by ELISA. Control cytokine levels were 480 4. $35 \mathrm{pg} / \mathrm{ml}$ for TNFo, $147.1 \pm 29.3 \mathrm{ng} / \mathrm{ml}$ for IL-6, and $190.0 \pm 40.6 \mathrm{ng} / \mathrm{ml}$ for IL-8. ${ }^{\circ}$ Percentage inhibition was calculated as $100 \%-(\%$ of control $)$. ${ }^{\circ} \mathrm{IC}$. were determined by extrapolation from dose-response curves of four separate experiments. Data are expressed as mean \pm SEM of four separate experiments.

\subsubsection{EFFECTS OF ADENOSINE ON IL-1B-INDUCED CYTOKINE RELEASE}

Next, to investigate whether the observed inhibition by adenosine was specific for endotoxin-induced cytokine release, or that adenosine might also act as an inhibitor of cytokine release by cytokine-activated monocytes, the effects of adenosine on $\mathrm{LL}-1 \beta$-induced cytokine release were determined. Adenosine also attenuated release of TNF $\alpha$ by monocytes activated with $100 \mathrm{U} / \mathrm{ml} \mathrm{IL}-1 \beta$, but to a lesser extent than LPS-induced TNF $\alpha$ release (Figure 3.4). However, adenosine up to a concentration of $200 \mu \mathrm{M}$ was ineffective in reducing IL-6 and IL-8 production after stimulation with IL $-1 \beta$ for $6 h$. On the contrary, adenosine in a concentration of $10 \mu \mathrm{M}$ and higher, significantly stimulated release of IL-6 ( $p<0.05$ vs. control), while no significant effects on IL-8 release were apparent. However, at $24 \mathrm{~h}$ the presence of $100 \mu \mathrm{M}$ adenosine markedly enhanced IL-1 $\beta$ induced IL-6 as well as IL-8 release (Figure 3.5). Similar results were obtained with monocytes stimulated with TNF $\alpha$, where adenosine also enhanced the release of IL -6 and IL -8 during a 24 h incubation period (data not shown). 
Figure 3.4 Modulation of $L-1 \beta$-induced cytokine release by adenosine and receptor-specific adenosine analogues
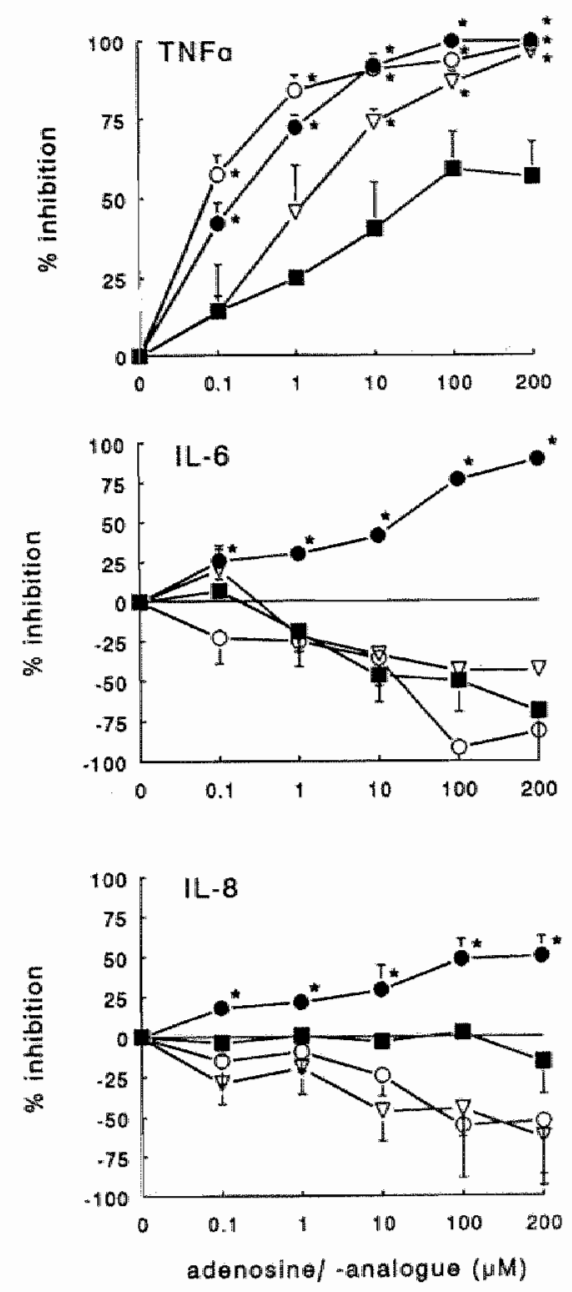

Monocytes were incubated with rhIL-1 $\beta(100 \mathrm{U} / \mathrm{ml})$ and a concentration range of either adenosine $(\mathbf{\square})$, NECA $(0), 2-C A d o(-)$ or CPA $(\nabla)$ for $6 \mathrm{~h}$. Control cultures were incubated with rhIL-1 $\beta$ alone. The supernatants were collected and cytokine release was determined by ELISA. Control cytokine levels were $78 \pm 25 \mathrm{pg} / \mathrm{ml}$ for TNF $\alpha, 16.3 \pm 2.8 \mathrm{ng} / \mathrm{ml}$ for $7 \mathrm{~L}-6$, and $34.8 \pm 10.8 \mathrm{ng} / \mathrm{ml}$ for IL-8. Percentage inhibition was calculated as $100 \%-\%$ of control. Results are shown as mean + SEM of four cultures. Error bars are omitted if they fall within the symbol. * indicates a statistically significant difference compared to adenosine. 
Chapter 3

Wigture 3.5 Adenosine enhances release of $I L-6(A)$ and $I L-8(B)$ after stimulation with $L-I \beta$
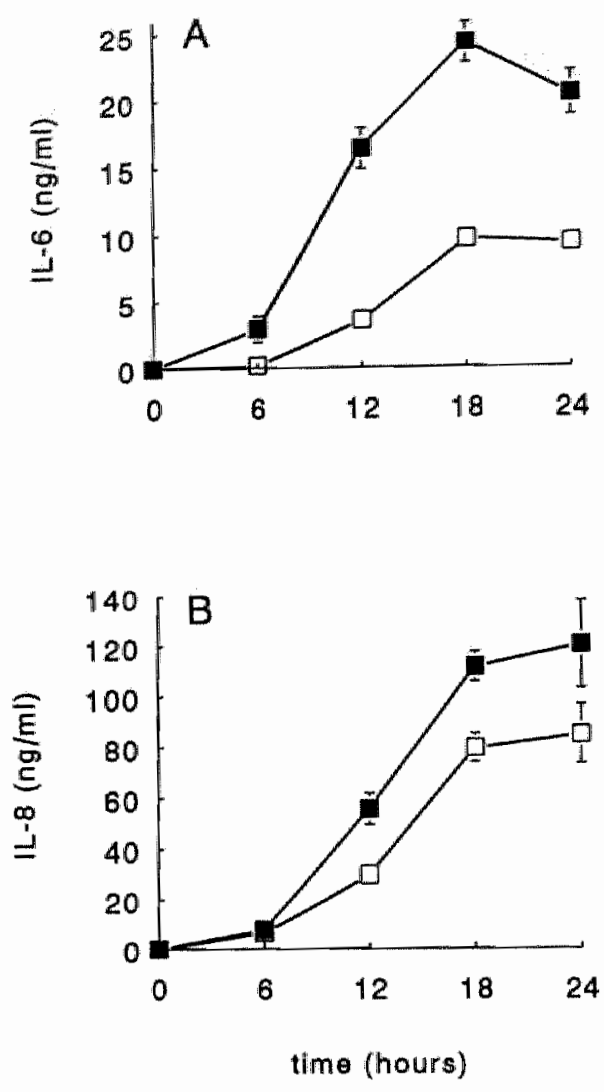

Monocytes were incubated with $\mathrm{r} / \mathrm{LL}-1 \beta(100 \mathrm{U} / \mathrm{m})$ in the absence ( $\square$ ) or presence of 100 $\mu \mathrm{M}$ adenosine for $24 \mathrm{~h}$. At the indicated timepoints supernatants were collected and cytokine release was determined by ELISA. The results of one experiment, representative of three, are shown. Data are expressed as mean \pm SEM of six determinations. Error bars are omitted if they fall within the symbol.

\subsubsection{EFFECT OF A1 AND A2 RECEPTOR-SPECIFIC ADENOSINE ANALOGUES ON CYTOKINE RELEASE}

After having established that adenosine affected cytokine release by stimulated monocytes, we investigated whether these effects could be related to occupancy 
of specific adenosine receptors. Since establishing the potency order of receptor-specific agonists has become the preferred method for classification of adenosine receptors (19), we compared the inhibitory capacity of adenosine with that of its $\mathrm{A} 1$ and $\mathrm{A} 2$ analogues. The A2 receptor-specific agonist 2-CAdo exerted a much stronger inhibitory effect than adenosine on LPS-induced cytokine release (Figure 3.2). NECA, a weak A2-selective adenosine agonist (41), was equally effective as 2 -chloroadenosine in attenuating TNFo release, but was less potent in reducing $\mathbb{I L}-6$ and IL-8 release in response to endotoxin. However, NECA in a concentration range of 0.1 to $10 \mu \mathrm{M}$ still attenuated IL-6 and IL-8 release more potently than equimolar concentrations of adenosine. In contrast, the A1-specific agonist CPA was less effective than the A2 receptor agonists in attenuating LPS-induced cytokine release, while the naturally occurring adenosine analog 2'-deoxyadenosine, which is modified in the ribose moiety, was ineffective. The observed order of potency of adenosine and its analogues to inhibit cytokine release was 2 -CAdo $\geq$ NECA $\geq$ adenosine $\geq$ CPA $>2$-deoxyadenosine, which indicates that the inhibition is primarily an A2 receptor-mediated event. An almost similar order of potency was observed with inhibition of $[\mathrm{L}-1 \beta$-induced TNF $\alpha$ release (Figure 3.4), although CPA at a concentration of $10 \mu \mathrm{M}$ and higher inhibited TNF $\alpha$ release more potently than adenosine. Contrary to these observations, only the $\mathrm{A} 2$ receptor agonist 2-CAdo was effective in reducing cytokine-induced IL-6 and IL-8 release. Like adenosine, NECA as well as CPA at concentrations of $10 \mu \mathrm{M}$ and higher significantly enhanced release of IL-1 $\beta$-induced IL-6 release $(p<0.05$ ws. control). NECA and CPA also tended to increase cytokine-induced IL-8 release, but no statistically significant difference compared to controls was reached at any of the concentrations used (Figure 3.4).

Adenosine as well as 2'-deoxyadenosine are substrates for degradation to inosine or 2'-deoxyinosine by the cytosolic enzyme adenosine deaminase, whereas the synthetic receptor-specific analogues are not. Since endogenous adenosine deaminase might be induced in activated monocytes, an event which could hamper the comparison of the activity of adenosine or 2'-deoxyadenosine with that of its synthetic analogues, the effects of the adenosine deaminase inhibitor deoxycoformycin, on the observed actions of adenosine and $2^{2}$ deoxyadenosine on cytokine release were determined. Addition of $10-100 \mu \mathrm{M}$ deoxycoformycin did not significantly alter adenosine-mediated inhibition of LPS-induced TNF $\alpha$ release (Figure 3.6) and IL-IB-induced TNF $\alpha$ release (data not shown), indicating that the activity of exogenously added adenosine is not substantially affected by endogenous adenosine deaminase. In line with these observations, inhibition of LPS-induced IL- 6 and IL-8 was slightly, but non- 
significantly, enhanced in the presence of deoxycoformycin, while potentiation of IL-1B-induced $I L-6$ and $I L-8$ by exogenous adenosine was not altered by adenosine deaminase inhibition (data not shown). In the absence of adenosine or 2'-deoxyadenosine, $10 \mu \mathrm{M}$ deoxycoformycin inhibited release of LPSinduced TNF $\alpha$ by $23.8 \pm 14.9 \%$, although statistical significance was not reached (Figure 3.6). Nevertheless, this finding suggests that there is endogenous adenosine activity, which, in absence of endogenous adenosine deaminase activity, results in attenuation of TNF $\alpha$ release. Finally, during inhibition of endogenous adenosine deaminase by deoxycoformycin, cytokine levels in the presence of $2^{\prime}$-deoxyadenosine did not differ from controls (data not shown), which confirms that, despite inhibition of its breakdown, 2'deoxyadenosine has no effects on cytokine release by activated monocytes.

Figure 3.6 Effects of inhibition of endogenous adenosine deaminase on TNF c release

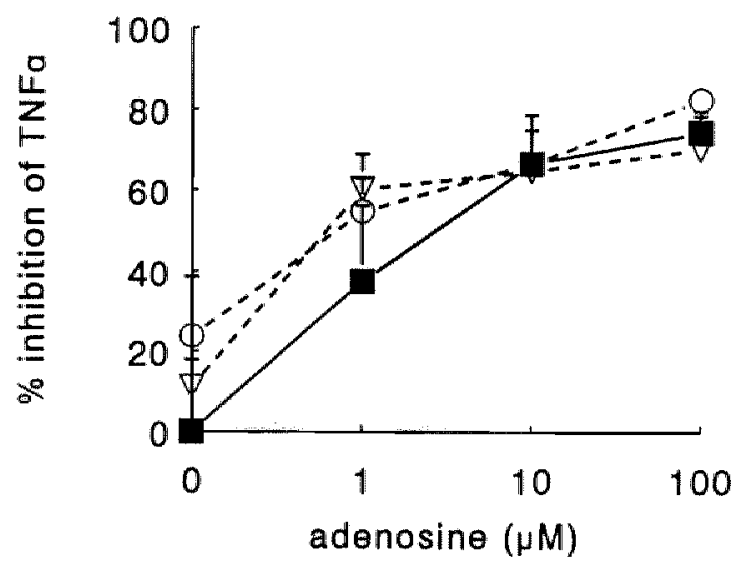

Monocytes were incubated with LPS $(10 \mathrm{ng} / \mathrm{mll})$ and 0 to $100 \mu \mathrm{M}$ adenosine in the absence (a) or presence of $10(0)$ or $100 \mu \mathrm{M}(\nabla)$ deoxycoformycin for $6 \mathrm{~h}$. The supernatants were collected and cytokine release was determined by ELISA. Data are expressed as mean + SEM of three cultures. Error bars are omitted if they fall within the symbol. 


\subsubsection{EFFECT OF NUCLEOSIDE UPTAKE INHIBITION}

To test whether cellular uptake of adenosine by monocytes was required for the inhibitory effects on cytokine release, the nucleoside transport inhibitor $R$ 88021 (Draflazine) was coincubated with adenosine and LPS. To this end, cells were preincubated with R 88021 for 5 minutes, and next adenosine and LPS were added. $R 88021$ is the active $\mathbb{L}$-enantiomer of $R 75231$, a racemic mixture with a very specific and effective capacity to inhibit adenosine transport across cellular membranes (42). As shown in Figure 3.7, R 88021 did not affect inhibition of LPS-induced TNF $\alpha$ release by adenosine. These findings indicate that uptake of exogenously added adenosine by monocytes is not a prerequisite for the inhibitory effects described above.

Figure 3.7 Nucleoside uptake blockade does not affect inhibition of TNFa release by adenosine

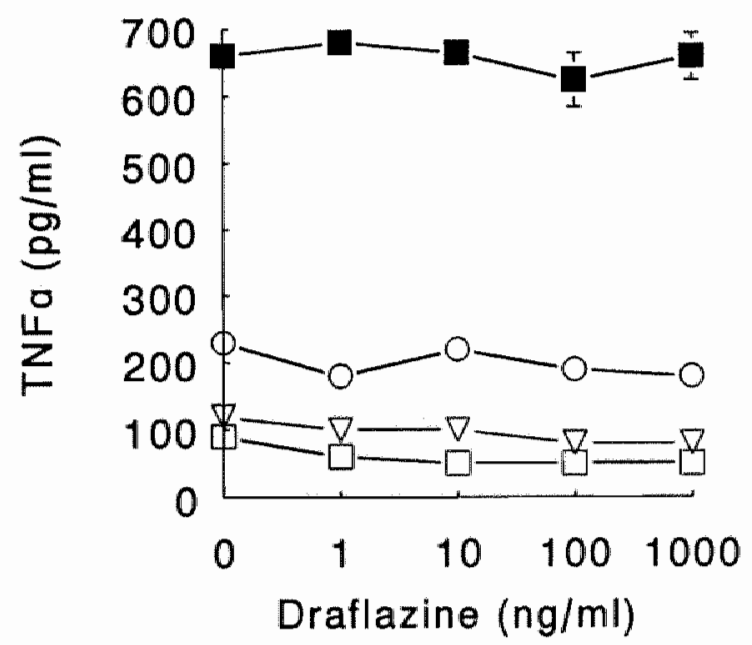

Monocytes were preincubated for 5 min with the nucleoside transport inhibitor R. 88021 at the indicated concentrations and subsequently coincubated with LPS $(10 \mathrm{ng} / \mathrm{ml})$ in the absence (a) or presence of either $10(0), 100(\Delta)$ or $200 \mu \mathrm{M}(\square)$ adenosine for $6 \mathrm{~h}$. The supernatants were collected and cytokine release was determined by ELISA. The results of one experiment, representative of four, are shown. Data are expressed as mean \pm SEM of triplicate determinations. Error bars are omitted if they fall within the symbol. 


\subsection{DISCUSSION}

Adenosine is an endogenous nucleoside that exerts a wide variety of biological effects via distinct cell-surface receptors $(5,6)$. Since formation and release of adenosine is closely linked to ATP catabolism during increased metabolic demands, Newby introduced the term "retaliatory metabolite" to describe the actions of adenosine under these circumstances (9). Adenosine has been shown to attenuate reperfusion injury following ischemia of the myocardium (21), brain (23), and spinal cord (20), while Marts et al. recently reported a protective effect of the adenosine analogue 2-CAdo on reperfusion injury of the lung (22). The protective actions of adenosine on the deleterious consequences of ischemia and reperfusion injury are considered to be mediated by several distinct mechanisms. Adenosine restores the ischemia-induced disturbance of energy metabolism (9). Furthermore, adenosine participates in the autoregulation of blood flow in various organs and tissues (7). It induces vasodilatation in heart, brain and skeletal muscle, thereby increasing oxygen supply during ischemia and counteracting the "no-reflow" phenomenon. Moreover, the anti-inflammatory role of adenosine during ischemia and reperfusion is of specific importance. Formation of oxygen free radicals by activated neutrophils and enhanced adhesion of neutrophils to endothelial cells are crucial events in the pathogenesis of reperfusion injury. Adenosine inhibits superoxide anion generation by activated neutrophils (10-12), and reduces neutrophil adherence to endothelial cells $(13,15)$, thereby providing protective anti-inflammatory effects on reperfusion injury.

In this study, we have shown that adenosine and $A 2$ receptor-specific adenosine analogues inhibit the release of TNF $\alpha$, IL- 6 and IL- 8 by activated monocytes. The conclusion that adenosine, and not its metabolites, is responsible for these effects, is based on two observations. First, when deamination of exogenous adenosine to inosine by endogenous adenosine deaminase was prevented using the adenosine deaminase inhibitor deoxycoformycin, the effects on cytokine release were not altered. This strongly suggests that indeed adenosine and not its metabolite inosine is responsible for these actions. Second, to further confirm this, the effects of exogenous inosine on cytokine release were tested. Inosine, used in a concentration range of 1 to $200 \mu \mathrm{M}$, had no effects on either LPS- or IL-1B-induced cytokine release (data not shown).

In addition to the already described actions on leukocyte function, the inhibitory effects of adenosine on cytokine release by activated monocytes may constitute another important mechanism of its anti-inflammatory action. Besides 
neutrophils, mononuclear phagocytes also play an important role in acute inflammatory responses, mainly by producing and secreting inflammatory cytokines upon activation with specific stimuli. Excessive cytokine production by mononuclear phagocytes is associated with severe clinical conditions, such as septic shock and ischemia-reperfusion injury. Immuno-neutralization of TNF $\alpha$ has been shown to have protective effects in animal models of hepatic $(31,43)$, hind limb $(27,28)$, intestinal $(32)$, pulmonary $(29)$ and myocardial (30) ischemia-reperfusion injury. Likewise, a role for $\mathbb{L L}-6$ has been suggested in hepatic (43), hindlimb (27) and myocardial (44) ischemia and reperfusion. Also, there is evidence that functional inhibition of IL- 8 by specific antibodies prevents lung reperfusion injury $(33,34)$. Although in these in vivo studies the exact cellular sources of cytokine production under such conditions have not always been established with certainty, mononuclear phagocytes are very likely candidates. Indeed, several in vitro studies have indicated that anoxia or hypoxia followed by reoxygenation can directly stimulate monocytes and macrophages to release cytokines (45-48). Reported beneficial effects of experimental interventions with A2-specific adenosine analogues (22) or compounds that increase or prolong the biological availability of endogenously released adenosine at local sites of injury, such as acadesine $(8,49)$, nucleoside transport inhibitors (42) or adenosine deaminase inhibitors (50), might therefore be attributed, at least in part, to the inhibition of cytokine production and release. Whether, as a result of intervention with these substances, cytokine levels during ischemia and reperfusion are actually diminished by the described inhibitory actions of adenosine on mononuclear phagocytes, remains to be investigated.

We have demonstrated in this study that adenosine in the micromolar concentration range attenuates TNF $\alpha$ release and, to a lesser extent, also IL-6 and IL-8 release by endotoxin-stimulated human peripheral blood monocytes. This observation suggests that, under these conditions, adenosine acts via a common inhibitory pathway. Thus far, the inhibitory pathway of adenosine in $\mathrm{PMN}$ and mononuclear phagocytes has not been completely revealed. It has been established that adenosine, via A2 receptors, increases intracellular cAMP through stimulation of adenylate cyclase. Since LPS-induced expression of genes encoding for TNF $\alpha$, as well as IL-6 and IL-8 is commonly controlled by the inducible transcription factor $N F-\kappa B(51)$, it could be hypothesized that interference of adenosine with activation or mobilization of NF- $\mathrm{KB}$ is responsible for the common inhibitory effects on LPS-induced cytokineproduction, as observed in this study. Interestingly, Strieter et al. (52) reported that an increase in cAMP interferes with endotoxin-induced transcription of the 
TNF $\alpha$ gene. However, cAMP-raising agents such as pentoxifylline and theophylline, selectively inhibit LPS-induced synthesis of TNF $\alpha$, but do not affect the production of $1 \mathrm{~L}-6$ in vitro (53). These observations make the existence of a CAMP-mediated common inhibitory pathway for TNF $\alpha$ and IL- 6 doubtful. Therefore, the exact molecular mechanisms of action of adenosine involved in the observed specificity of cytokine-inhibition (TNF $\alpha>\mathrm{IL}-6>\mathrm{IL}$ 8) remain to be elucidated.

Our finding that adenosine attenuates TNF $\alpha$ release by endotoxin-stimulated monocytes is supported by data recently reported by Parmeley et al. (37), who found selective inhibition of TNF $\alpha$ production by LPS-activated mouse peritoneal macrophages and mouse macrophage-like cell lines in vitro. In their experiments a $100 \mu \mathrm{M}$ concentration of adenosine inhibited TNF $\alpha$ production by more than $80 \%$ with $\mathrm{IC}_{50}$ ranging from 1 to $10 \mu \mathrm{M}$, findings which correspond well with our observations. These authors suggested that inhibition of TNF $\alpha$ production may be independent of specific adenosine receptor ligation, since the synthetic adenosine analogue MDL201112, which binds with only low affinity to classical A1 and A2 receptors, potently reduced LPSinduced TNF $\alpha$-levels both in vitro and in vivo. These data however, do not preclude the possibility of inhibition of cytokine release by specific adenosinereceptors. In our hands, the $\mathrm{A} 2$ receptor-specific adenosine analogues 2-CAdo and NECA exerted stronger inhibitory effects on endotoxin-induced cytokine release than adenosine or the Al receptor-specific agonist CPA, which suggests that this inhibition is primarily an $\mathrm{A} 2$ receptor-mediated event. The finding that the A1-selective agonist CPA inhibited TNF $\alpha$ release to the same extent as adenosine is compatible with non-specific A2 receptor binding of CPA at higher concentrations (41), and further substantiates that endotoxin-induced TNF $\alpha$ release is highly sensitive to $A 2$ receptor-mediated inhibition.

In contrast with the broad inhibitory effects of adenosine on LPS-induced cytokine release, adenosine up to $200 \mu \mathrm{M}$ was ineffective in reducing IL-6 and IL-8 release by monocytes stimulated with $I L-1 \beta$. Moreover, we found that adenosine significantly increased IL-6 levels in the culture supernatants after 6 $\mathrm{h}$ of stimulation with $\mathrm{IL}-1 \beta$. This potentiating effect was evident for II- 6 as well as IL-8 during a $24 \mathrm{~h}$ incubation period. Enhancement of IL-6 and IL-8 release was also found during stimulation of monocytes with TNF $\alpha$ (data not shown). These findings show that adenosine has opposing effects on the release of $\mathrm{IL}-6$ and IL- 8 by activated monocytes, depending on the specific stimulus used. In the same supernatants however, IL-1 $\beta$-induced TNF $\alpha$ release was inhibited by adenosine in a similar manner as TNF $\alpha$ release in response to endotoxin, albeit that maximal inhibition was only $60 \%$. This discrepancy between the inhibitory 
effects of adenosine on TNF $\alpha$ release on the one hand, and the potentiating effects on IL-6 and IL-8 release on the other hand, further argues against a common inhibitory mechanism.

The potency order of receptor-specific agonists with regard to inhibition of TNF $\alpha$ during stimulation with IL-1 $\beta$ was almost identical to that observed with LPS-induced TNF $\alpha$, although CPA at concentrations of $10 \mu \mathrm{M}$ and higher inhibited TNF $\alpha$ release even stronger than adenosine, which is consistent with the aforementioned non-specific A2 receptor ligation of CPA at higher concentrations. The A2-specific agonist 2-CAdo strongly inhibited $I L-1 \beta$ induced $\Pi L-6$ and $I L-8$, whereas the weaker A2-specific agonist NECA as well as the A1-selective agonist CPA potentiated the release of these cytokines. Since equivalent concentrations of CPA had similar effects as NECA, being approximately equipotent at $\mathrm{A} 1$ and $\mathrm{A} 2$ receptors, the potentiating effects of NECA can not be ascribed to A2 receptor-mediated processes (41). It is tempting to speculate that enhancement of IL-1 $1 \beta$-induced cytokine release may be a result of $\mathrm{A} 1$ receptor binding, but further study is warranted to substantiate this.

Finally, our observation that a synthetic A2-specific adenosine analogue, such as 2-CAdo, inhibited endotoxin-induced cytokine production more potently than the Al-specific agonist CPA, coupled to the fact that adenosine uptake blockade did not affect this inhibition, suggests that freshly isolated monocytes express functional A2 receptors on their surface membrane. The expression of both adenosine $\mathrm{A} 1$ and $\mathrm{A} 2$ receptors has been reported however, to be a characteristic of macrophages, derived from in vitro culture of human peripheral blood monocytes $(24,54)$. These studies focused on the inhibitory effects of adenosine on phagocytic function of mononuclear phagocytes. Contrary to these observations however, but in agreement with the data we present here, Baker et al. (55) demonstrated that human peripheral blood monocytes were sensitive to the inhibitory effects of adenosine and NECA on zymosan-induced release of thromboxane and lysozymal enzymes, suggesting the presence of functional A2 receptors on freshly isolated human monocytes.

In conclusion, we have shown that adenosine in micromolar concentrations strongly inhibits TNF $\alpha$ release by activated monocytes. Release of IL-6 and IL8 can be either inhibited or potentiated by adenosine, depending on the stimulus. Furthermore, our data strongly indicate that specific A2 receptor ligation by 2 -CAdo potently reduces the release of TNF $\alpha$, IL- 6 and IL- 8 by monocytes, stimulated with either LPS or the inflammatory cytokines IL-1 $\beta$ and TNF $\alpha$. 
This modulating effect on cytokine release is consistent with the already established role of adenosine as a physiological endogenous regulator of leukocyte function. In this study a consistent, albeit relatively small, effect of endogenous adenosine on cytokine release by activated monocytes was observed, when its breakdown by adenosine deaminase was inhibited with deoxycoformycin. The modulatory effects of endogenous adenosine were comparable to the effects of approximately $1 \mu \mathrm{M}$ of exogenous adenosine, a concentration that resembles levels found in vivo (2-4).

Based on the observations described above, we hypothesize that, specifically during ischemia-reperfusion, adenosine may act to attenuate injury by inhibiting cytokine release. In this context, adenosine might be a component of the normal host defense in mild ischemic foci. In more severe ischemic events, when local release of endogenous adenosine might be insufficient to prevent tissue damage, the use of A2-selective adenosine agonists or substances that retain endogenously released adenosine at local sites of injury could potentiate the inhibitory effects of adenosine on cytokine release.

\section{REFERENCES}

1. Cronstein BN, Daguma L, Nichols D, Hutchison AJ, Williams $M$. The adenosine/neutrophil paradox resolved: human neutrophils possess both A1 and A2 receptors that promote chemotaxis and inhibit 02 -generation, respectively. $J$ Clin Invest 85: $1150-1157,1990$.

2. Fox AC, Reed GE, Meilman H, Silk BB. Release of nucleosides from canine and human hearts as an index of prior ischemia. Am J Cardiol 43: 52-58, 1979.

3. Van Belfe $\mathrm{H}$, Goossens $\mathrm{F}$, Wynants J. Formation and release of purine catabolites during hypoperfusion, anoxia and ischemia. Am J Physiol 252: H886-H893, 1987.

4. Matherne GP, Headrick JP, Coleman SD, Berne RM. Interstitial transudate purines in normoxic and hypoxic immature and mature rabbit hearts. Pediatr Res 28: 348-353, 1990.

5. Stiles GL. Adenosine receptors. J Biol Chem 267: 6451-6454, 1992.

6. Fox IH, Kelley WN. The role of adenosine and $2^{\prime \prime}$-deoxyadenosine in mammalian cells. Ann Rev Biochem 47: 655-686, 1978.

7. Collis MG. The vasodilator role of adenosine. Pharmac Ther 41: 143-162, 1989.

8. Gruber HE, Hoffer ME, McAllister DR, Laikind PK, Lane TA, Schmid-Schoebein GW, Engler RL. Increased adenosine concentration in blood from ischemic myocardium by AlCA riboside. Circulation 80: 1400-1411, 1989.

9. Newby AC. Adenosine and the concept of retaliatory metabolites. Trends Biochem Sci 9 : $42-44,1984$.

10. Cronstein BN, Kramer SB, Weissman G, Hirschhorn R. Adenosine: a physiological modulator of superoxide anion generation by human neutrophils. J Exp Med 158: 1160$1177,1983$. 
11. De La Harpe J, Nathan CF. Adenosine regulates the respiratory burst of cytokine-triggered human neutrophils adherent to biological surfaces. I Immonol 143: 596-602, 1989.

12. Pham Huu T, Bendahou M, Sourbier P, Hakim J. Adenosine as a modulator of the inflammatory process. Int J Immonotherapy VI(1): 19-25, 1990.

13. Grisham MB, Hernandez LA, Granger DN. Adenosine inhibits ischemia-reperfusion-induced leukocyte adherence and extravasation. Am J Physiol 257: H1334-H1339, 1989.

14. Jurgensen $\mathrm{CH}$, Huber BE, Zimmerman TP, Wolberg G. 3-deazaadenosine inhibits leukocyte adhesion and ICAM-1 biosynthesis in tumor necrosis factor-stimulated human endothelial cells. J Immunol 144: 653-661, 1990.

15. Nolte D, Lorenzen A, Lehr H-A, Zimmer F-J, Klotz K-N, Messmer K. Reduction of postischemic leukocyte-endothelium interaction by adenosine via $A 2$ receptor. Naunyn-Schmiedebergs Arch Pharmacol 346: 234-237, 1992.

16. Asako H, Wollf RE, Granger DN. Leukocyte adherence in rat mesenteric venulles: effects of adenosine and methotrexate. Gastroenterology 104:31-37, 1993.

17. Rose FR, Hirschhorn R, Weissman G, Cronstein BN. Adenosine promotes neutrophil chemotaxis. J Exp Med 167: 1186-1194, 1988.

18. Cronstein BN, Levin RI, Philips M, Hirschhorn R, Abramson SK, Weissman G. Neutrophil adherence to endothelium is enhanced via adenosine Al receptors and inhibited via adenosine A2 receptors. J Immunol 148: 2201-2206, 1992.

19. Wollner $A$, Wollner $S$, Smith $J_{B}$ Acting via A2 receptors, adenosine inlibits the upregulation of Mac-1 (CD1 1b/CD18) expression on FMLP-stimulated neutrophils. $A m$ J Respir Cell Mal Biol 9: 179-185, 1993.

20. Seibel PS, Theodore P, Kron IL, Tribble CG. Regional adenosine attenuates postischemic spinal cord injury. J Vasc Surg 18: 153-158, 1993.

21. Forman MB, Velasco CE, Jackson EK. Adenosine attenuates reperfusion injury following regional myocardial ischaemia. Cardiovasc Res 27: 9-17, 1993.

22. Marts BC, Baudendistel LJ, Naunheim KS, Dahms TE. Protective effect of 2-chloroadenosine on lung ischemia reperfusion injury. $J$ Swg Res $54: 523-529,1993$.

23. Rudolphi KA, Schubert P, Parkinson FE, Fredholm BB. Neuroprotective role of adenosine in cerebral ischaemia. Trends Pharmacol Sci 13: 439-445, 1992.

24. Salmon JE, Brogle $\mathbb{N}$, Brownlie C, Edberg JC, Kimberly RP, Chen B-X, Erlanger BF. Human mononuclear phagocytes express adenosine Al receptors. J Immunol $151: 2775$ $2785,1993$.

25. Shalaby MR, Waage A, Aarden L, Espevik T. Endotoxin, tumor necrosis factor- $\alpha$ and interleukin 1 induce interleukin 6 production in vivo. Clin Immunol Immunopathol 53: $488-498,1989$.

26. Fong $\mathrm{Y}$, Lowry SF. Tumor necrosis factor in the pathophysiology of infection and sepsis. Chin Immunol Immunopathol 55: 157-170, 1990.

27. Seekamp A, Warren IS, Remick DG, Till GO, Ward PA. Requirements for tumor necrosis factor- $\alpha$ and interleukin- 1 in limb ischemia/reperfusion injury and associated lung injury. Am J Pathol 143: 453-463, 1993.

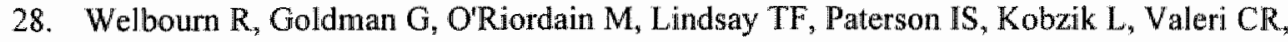
Shepro D, Hechtman HB. Role for tumor necrosis factor as mediator of lung injury following lower torso ischemia. I Appl Physiol 70: 2645-2649, 1991. 
29. Palace GP, Del Vecchio PJ, Horgan MJ, Malik AB. Release of tumor necrosis factor after pulmonary artery ocelusion and reperfusion. Am Rev Respir Dis 147: 143-147, 1993.

30. Squadrito F, Altavilla D, Zingarelli B, loculano $M$, Calapai G, Campo GM, Miceli A, Caputi AP. Tumor necrosis factor involvement in myocardial ischaemia-reperfusion injury. Eur J Pharmacol 237: 223-230, 1993.

31. Coletti LM; Remick DG, Burtch GD, Kunkel SL, Strieter RM, Campbell DA. Role of tumor necrosis factor-ce in the pathophysiological alterations after hepatic ischemia/reperfusion injury in the rat. J Clin Invest 85: 1936-1943, 1990.

32. Caty MG, Guice KS, Oldham KT, Remick DG, Kunkel SL. Evidence for tumor necrosis factor-induced pulmonary microvascular injury after intestinal ischemia-reperfusion injury. Ann Surg 212: 694-700, 1990.

33. Sekido N, Mukaida $N$, Harada A, Nakanishi I, Watanabe $Y$, Matsushima $K$. Prevention of lung reperfusion injury in rabbits by a monoclonal antibody against interleukin-8. Nature 365: 654-657, 1993.

34. Wickersham NE, Loyd JE, Johnson JE, McCain RW, Christman JW. Acute inflammation in a sheep model of unilateral lung ischemia: the role of interleukin-8 recruitment of polymorphonuclear leukocytes. Am J Respir Cell Mol Biol 9: 199-204, 1993.

35. Strieter RM, Coletti LM, Metinko AP, Rolfe MW, DeMeester SR, Standiford TJ, Kunkel SL. The role of cytokine networks mediating inflammation and ischemiareperfusion injury. In Shock, sepsis and organ failure. Schlag G, Redl H, Traber D (Eds. ), Springer Verlag Berlin Heidelberg, pp. 205-227, 1993.

36. Kawamura $\mathrm{T}$, Wakusawa R, Okada $\mathrm{K}$, Inada $\mathrm{S}$. Elevation of cytokines during open heart surgery with cardiopulmonary bypass: participation of interleukin 8 and 6 in reperfusion injury. Can J Anaesth 40: 1016-1021, 1993.

37. Parmely MJ, Zhou W-W, Edwards III CK, Borcherding DR, Silverstein R, Morrison DC. Adenosine and a related carbocyclic nucleoside analogue selectively inhibit tumor necrosis factor- $\alpha$ production and protect mice against endotoxin challenge. I Immunol 151:389m396, 1993.

38. Graziano RF, Fanger MW. FcyRI and Fo $\gamma$ RI on monocytes and granulocytes are cytotoxic trigger molecules for tumor cells. J Immunol 139: 3536-3541, 1987.

39. Engelberts 1, Möller A, Schoen G.JM, Van der Linden CJ, Buurman WA. Evaluation of measurement of human TNF in plasma by ELISA. Lymfokine Cytokine Res 10: 69-76, 1991.

40. Dentener MA, Bažil V, Von Asmuth EJU, Ceska M, Buurman WA. Involvement of CDI4 in lipopolysaccharide-induced tumor necrosis factor- $\alpha$, IL- 6 and IL- 8 release by human monocytes and alveolar macrophages. J Immunol 150: 2885-2891, 1993.

41. Jacobson KA, Van Galen PJM, Williams M. Adenosine receptors: pharmacology, structure-activity relationships, and therapeutic potential. J Med Chem 35: 407-422, 1992.

42. Van Belle H. Nucleoside transport inhibition: a therapeutic approach to cardioprotection via adenosine? Cardiovasc Res 27: 68-76, 1993.

43. McCurry KR, Campbell DA, Scales WE, Warren IS, Remick DG. Tumor necrosis factor, interleukin 6, and the acute phase response following hepatic ischemia/reperfusion. J Surg Res 55: 49-54, 1993. 
44. Youker K, Smith CW, Anderson DC, Miller D, Michael LH, Rossen RD, Entman ML. Neutrophil adherence to isolated adult cardiac myocytes. Induction by cardiac lymph collected during ischemia and reperfusion. J Clin Invest 89: 602-609, 1992.

45. Ghezzi P, Dinarello CA, Bianchi M, Rosandich ME, Repine JE, White CW. Hypoxia increases production of interleukin- 1 and tumor necrosis factor by human mononuclear cells. Cytokine 3: 189-194, 1991.

46. Koga S, Ogawa S, Kuwabara $\mathbb{K}$, Brett J, Leavy JA, Ryan J, Koga Y, Plocinski J, Benjamin W, Burns DK, Stern D. Synthesis and release of interleukin I by reoxygenated human mononuclear phagocytes. J Clin Invest 90: 1007-1015, 1992.

47. Scannell G, Waxman K, Kaml GJ, loli G, Gatanaga T, Yamamoto R, Granger GA. Hypoxia induces a human macrophage cell line to release tumor necrosis factor- $\alpha$ and its soluble receptors in vitro. J Surg Res 54:281-285, 1993.

48. Metinko AP, Kunkel SL, Standiford TJ, Strieter RM. Anoxia-hyperoxia induces monocyte-derived interleukin-8. J Clin Invest 90: 791-798, 1992.

49. Mullane $K$, Bullough $D$, Shapiro $D$. From academic vision to clinical reality. A case study of acadesine. Trends Cardiovasc Med 3: 227-234, 1993.

50. Sandhu GS, Burrier AC, Janero DR. Adenosine deaminase inhibitors attenuate ischemic injury and preserve energy balance in isolated guinea pig heart. Am J Physiol 265: H1249-H1256, 1993.

51. Müller JM, Löms Ziegler-Heitbrock HW, Baeuerle PA. Nuclear factor kappa B, a mediator of lipopolysaccharide effects. Immunobiol 187: 233-256, 1993.

52. Strieter RM, Remick DG, Ward PA, Spengler RN, Lynch III JP, Larrick J, Kunkel SL. Cellular and molecular regulation of tumor necrosis factor-alpha production by pentoxifylline. Biochem Biophys Res Commun 155: 1230-1236, 1988.

53. Waage A, Sørensen M, Størdal B. Differential effect of oxpentifylline on tumour necrosis factor and interleukin-6 production. Lancet 335: 543, 1990.

54. Eppell BA, Newell AM, Brown EJ. Adenosine receptors are expressed during differentiation of monocytes to macrophages in vitro. J Immunol 143: 4141-4145, 1989.

55. Baker AJ, Fuller RW. Effect of cyclic adenosine monophosphate, 5 -(N-ethylcarboxamido)-adenosine and methylxanthines on the release of thromboxane and lysosomal enzymes from human alveolar macrophages and peripheral blood monocytes in vitro. Eur J Pharmacol 211: 157-161, 1992. 

CHAPTER 4

Adenosine Inhibits Cytokine Release and Expression of Adhesion Molecules

by Activated Human Endothelial Cells

Bouma MG, Van den Wildenberg FAJM, Buurman WA

American Journal of Physiology 270 (Cell Physiology 39): C522-C529, 1996 


\section{ABSTRACT}

Ischemia induces excessive ATP catabolism with subsequent local release of its metabolite adenosine, an autacoid with anti-inflammatory properties. Since activation of the vascular endothelium is critical to the inflammatory host response during ischemia and reperfusion, the effects of adenosine on two major determinants of endothelial cell activation, i.e. the release of proinflammatory cytokines and the expression of adhesion molecules, were studied. Adenosine dose-dependently inhibited the release of IL-6 and IL-8 by stimulated human umbilical vein endothelial cells (HUVEC). Expression of Eselectin and VCAM-1, but not ICAM-1, by activated HUVEC was also reduced by adenosine. Inhibition of endogenous adenosine deaminase activity by EHNA or 2'-deoxycoformycin strongly enhanced the inhibitory effects of exogenous adenosine on cytokine release and expression of E-selectin and VCAM-1. However, a clear role for specific adenosine-receptors in the described inhibitory events could not be established. Taken together, these data imply that the vascular endothelium constitutes an important target for the antiinflammatory actions of adenosine.

\subsection{INTRODUCTION}

During recent years it has been recognized that the physiological functions of the vascular endothelium extend well beyond its passive primary barrier function between the bloodstream and tissue. It is now known that the endothelium is an active "organ", that plays important regulatory roles in a variety of physiological homeostatic processes, such as inflammation, coagulation and regulation of vascular tone (1).

In the early stages of inflammation, pro-inflammatory cytokines such as interleukin-1 (IL-1) and tumor necrosis factor- $\alpha$ (TNF $\alpha$ ), as well as bacterial endotoxin can activate endothelial cells to produce a wide array of vasoactive, thrombogenic and inflammatory mediators (for review see Ref. 2). Amongst the inflammatory mediators elaborated by endothelial cells upon stimulation are the pleiotropic cytokines $\mathrm{IL}-1$ and IL-6 as well as the chemokine IL-8 (3). Moreover, stimulation of endothelial cells by cytokines or endotoxin results in de novo expression or upregulation of different classes of adhesion molecules, such as E-selectin, intercellular adhesion molecule-1 (ICAM-1) and vascular cell adhesion molecule-1 (VCAM-1), on their cell surface (4). Endothelial cell expression of adhesion molecules interacting with counterstructures on 
leukocytes is essential in the development of an inflammatory response. Thus as a result of endothelial cell activation, leukocytes are attracted to local sites of inflammation, become activated, adhere to the endothelium and finally transmigrate into the target tissue. Since chemotaxis and subsequent adherence of circulating leukocytes to the vascular endothelium are crucial events in the development of inflammatory reponses, they constitute important possible targets for therapeutical intervention in a variety of inflammatory disorders.

Adenosine is an endogenous intermediate of purine nucleotide metabolism with anti-inflammatory properties. Particularly during ischemia, local tissue levels of adenosine rise, as a consequence of ATP catabolism. Several in vivo studies have indicated that adenosine has protective effects on tissue injury following reperfusion after a preceeding period of ischemia. In this context, Newby has introduced the term "retaliatory metabolite" to describe the actions of adenosine during ischemia and reperfusion (5).

The anti-inflammatory actions of adenosine have been ascribed mainly to its modulatory effects on neutrophil function. In various in vitro experimental models, adenosine has been shown to affect neutrophil superoxide generation (6). Furthermore, adenosine interferes with neutrophil-endothelial adhesion (710 ), but it is still controversial whether the anti-adhesive activity of adenosine is exerted through its actions on polymorphonuclear leukocytes (PMN) alone, or that it may also result from its effects on endothelial cells. Finally, adenosine interferes with the phagocytic function and with the release of inflammatory mediators by mononuclear phagocytes (11-13). Recently, we and others reported that adenosine affects cytokine release by activated mononuclear phagocytes $(14,15)$.

In view of the important role of the vascular endothelium in the inflammatory host response, particularly in ischemia-reperfusion injury, we investigated the effects of adenosine on in vitro endothelial cell activation, as determined by the release of cytokines and the expression of adhesion moleculles.

\subsection{Materials AND METHODS}

\subsubsection{REAGENTS}

Adenosine, 2-chloroadenosine (2-CAdo), $N^{6}$-cyclopentyladenosine (CPA), erythro-9-(2-hydroxy-3-nonyl)adenine (EHNA), inosine, hypoxanthine and LPS (from Escherichia coli, serotype 055:LB5, catalog no. L-2880) were all 
obtained from Sigma Chemical Co. (St. Louis, MO). 2'Deoxycoformycin (dCF; CN81,565, lot no. R) was obtained from Warner-Lambert Co. (Ann Arbor, MI). Recombinant human TNF $\alpha$ was kindly provided by BASF/Knoll (Ludwigshafen, Germany). Recombinant human $\mathrm{IL}-1 \beta$ was a kind gift of Dr. S. Gillis (Immunex, Seattle, WA). RPMI 1640 was obtained from Life Technologies, Inc. (Paiisley, UK). Bovine calf serum (BCS), purchased from HyClone Laboratories (Logan, UT), was heat-inactivated for $30 \mathrm{~min}$ at $56^{\circ} \mathrm{C}$ and stored at $4^{\circ} \mathrm{C}$. Human serum (HS), obtained from healthy blood donors at the Red Cross Blood Bank Zuid Limburg (Maastricht, The Netherlands), after informed consent for research was given, was pooled, heat-inactivated, and stored at $4^{\circ} \mathrm{C}$.

\subsubsection{ENDOTHELIAL CELL CULTURE}

HUVEC were isolated from fresh human umbilical cords by collagenase treatment and were seeded into fibronectin-coated (fibronectin kindly provided by Dr. J. van Mourik, CLB, Amsterdam, The Netherlands) tissue-culture flasks (Costar Corp., Cambridge, MA) in complete medium consisting of RPMI 1640 supplemented with $50 \mu \mathrm{g} / \mathrm{ml}$ heparine (Sigma), $2 \mathrm{mM} \mathrm{L}$-glutamine, 100 IU penicillin and $100 \mu \mathrm{g} / \mathrm{ml}$ streptomycin, $30 \mu \mathrm{g} / \mathrm{ml}$ Endothelial Cell Growth Supplement (Collaborative Research Inc., Bedford, MA), 10\% BCS and 10\% HS. Endothelial cells were characterized by their pavement-like monolayer morphology, by positive staining with $\mathrm{mAb}$ hec7 (generously provided by Dr. W.A. Muller, Rockefeller University, NY) directed against PECAM-1 (16), and by positive staining with anti-E-selectin mAb ENA-1 (17) after 4 hours of incubation with TNF $\alpha$. Cultures never contained more than $1 \%$ non-endothelial cells.

For experiments, HUVEC passage 2-3 were plated onto 24-well or 96-well tissue culture plates (Costar Corp., Cambridge, MA) in complete media. When monolayers were confluent, the cells were rinsed once with RPMI-3\% BCS and incubated with the various reagents as indicated in RPMI-10\% BCS supplemented with glutamine and antibiotics for the indicated time periods. In all experiments, adenosine and its analogues were added simultaneously with either IL-1 1, TNF $\alpha$ or LPS. In experiments designed to test the effects of adenosine deaminase inhibition, cells were preincubated with either EHNA or $\mathrm{dCF}$ for $15 \mathrm{~min}$ and subsequently coincubated with the reagents as indicated. At the end of the indicated incubation periods, supernatants were collected and stored at $-20{ }^{\circ} \mathrm{C}$ until determination of cytokine levels by ELISA. For determination of purine levels by High Performance Liquid Chromatography, 
supernatants were deproteinized with $0.4 \mathrm{M}$ perchloric acid on ice, centrifuged at $1200 \mathrm{rpm}$ for $10 \mathrm{~min}$ at $4^{\circ} \mathrm{C}$, and neutralized with $0.4 \mathrm{M} \mathrm{K}_{2} \mathrm{HPO}_{4}$. Samples were kept at $-70{ }^{\circ} \mathrm{C}$ until determination of purine levels.

Viability of the cells was determined by cellular morphology on microscopic examination as well as by trypan blue exchusion. Cytotoxicity of the various treatments with adenosine or its analogues was assessed by methylthiazoltetrazolium (MTT) test (18).

\subsubsection{CYTOKINE ASSAYS}

Cytokine concentrations in culture supernatants were determined using previously described sandwich-ELISA's for IL-6 (19) and IL-8 (14). In short, 96-well Immuno Maxisorp plates (Nunc, Inc., Roskilde, Denmark) were coated overnight at $4{ }^{\circ} \mathrm{C}$ with cytokine-specific murine mAbs $5 \mathrm{E} 1$ (anti-IL-6) and HM5 (anti-IL-8). Recombinant human IL-6 and rhIL-8 were used for standard titration curves. Test samples were added and incubated for 2 to $3 \mathrm{~h}$ at room temperature. Each experimental sample was assayed at least in duplicate. Polyclonal rabbit anti-human $\mathrm{LL}-6$ and biotinylated polyclonal rabbit antihuman IL-8 Abs were incubated at room temperature for $1 \mathrm{~h}$, followed by a $1-\mathrm{h}$ incubation with peroxidase-conjugated goat anti-rabbit IgG (Jackson ImmunoResearch, West Grove, PA) for IL-6, and peroxidase-labelled streptavidin for IL-8. Finally, 3,3',5,5'-tetramethylbenzidine (Kirkegaard and Perry, Gaithersburg, MD) was added as substrate. The reaction was stopped after 15 min with $1 \mathrm{M} \mathrm{H}_{2} \mathrm{SO}_{4}$ and photospectrometry was performed at $450 \mathrm{~nm}$. The lower detection limits of the ELISA's were $10 \mathrm{pg} / \mathrm{ml}$ for IL-6 and $5 \mathrm{pg} / \mathrm{ml}$ for IL-8. To exclude the possibility that the presence of adenosine or its tested analogues interfered with detection of cytokines in the ELISA's, cytokinecontaining control samples were diluted in PBS-0.1\% BSA with a $100 \mu \mathrm{M}$ concentration of adenosine or analogues, and cytokine recovery as compared to control samples diluted in PBS- $0.1 \%$ BSA was determined. No interference with cytokine detection occurred in any of the ELISA's used (data not shown).

\subsubsection{EXPRESSION OF ADHESION MOLECULES}

HUVEC passage 2-3 were plated onto fibronectin-coated 96-well flat-bottom cell culture plates (Costar Corp., Cambridge, MA) in complete medium two days prior to experiments. Confluent monolayers were incubated for the indicated time periods with the various reagents as described above in RPMI$10 \% \mathrm{BCS}$ supplemented with glutamine and antibiotics. The cells were rinsed 
three times with PBS supplemented with calcium and magnesium, and fixed with $0.025 \%$ glutaraldehyde for 10 min at room temperature. Finally, the fixed monolayers were rinsed five times with $\mathrm{PBS}$, the wells were incubated with $1 \%$ bovine serum albumin in PBS, and kept at $4^{\circ} \mathrm{C}$ until use in ELISA. Cell-surface expression of E-selectin, ICAM-1 and VCAM-1 was detected by incubation for $2 \mathrm{~h}$ at room temperature with mAbs ENA-1 (anti-E-selectin) (20), RR-1 (antiICAM-1, a kind gift of Dr. R. Rothlein, Boehringer Ingelheim Pharmaceuticals, Inc., Ridgefield, CT) and IGI1 (anti-VCAM-1, a kind gift of Dr. D.O. Haskard, Hammersmith Hospital, Department of Rheumatology, London, U.K.) (20) respectively, followed by incubation with peroxidase-conjugated goat antimouse IgG (Jackson ImmunoResearch, West Grove, PA) for 1. h. TMB was added as substrate, and the reaction was stopped after $15 \mathrm{~min}$ with $1 \mathrm{M} \mathrm{H}_{2} \mathrm{SO}_{4}$. Photospectrometry was performed at $450 \mathrm{~nm}$.

\subsubsection{STATISTICAL ANALYSIS}

All data are presented as mean \pm SEM. Differences between the various treatments were tested as indicated by Wilcoxon signed rank test, Student $t$-test or by one-way analysis of variance, followed by Bonferroni's $t$-test when overall variation was significant. Differences were considered to be statistically significant at $p<0.05$.

\subsection{RESULTS}

\subsubsection{EFFECTS OF ADENOSINE ON CYTOKINE RELEASE}

Stimulation of HUVEC with concentration ranges of either $[L-1 B(1-100 \mathrm{U} / \mathrm{ml})$, TNF $\alpha(0.1-100 \mathrm{ng} / \mathrm{ml})$ or LPS $(1-100 \mathrm{ng} / \mathrm{ml})$ induced a dose-dependent release of IL-6 and IL-8 (data not shown). Coincubation of these cultures with a $100 \mu \mathrm{M}$ concentration of adenosine resulted in inhibition of the release of both cytokines, the rate of which was dependent on the concentration of the specific stimulus used (Figure 4.1). When HUVEC were activated with a low dose of either LL-1ß $(1 \mathrm{U} / \mathrm{ml})$, TNF $\alpha(0.1 \mathrm{ng} / \mathrm{ml})$ or LPS $(1 \mathrm{ng} / \mathrm{ml}), 100 \mu \mathrm{M}$ adenosine did not significantly alter release of IL-6 as compared to control cultures stimulated in the absence of adenosine. Similarly, no significant effect of adenosine on release of IL- 8 was observed during activation with low doses of the pro-inflammatory stimuli. 
Figure 4.1 Inhibitory effects of adenosine on cytokine release are dependent on the concentration of the stimulus
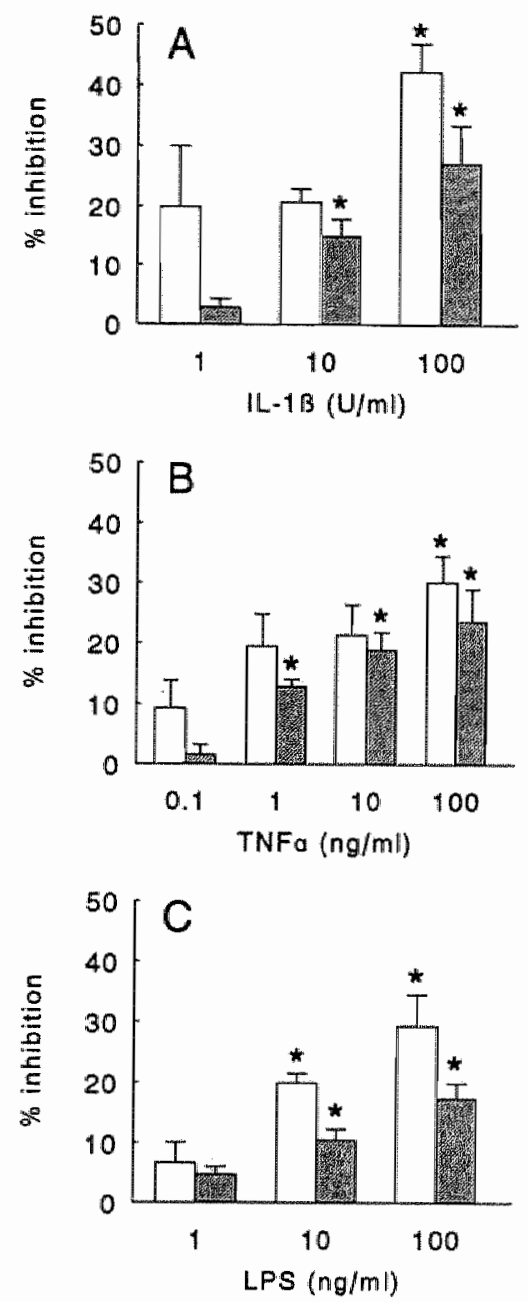

HUVEC were activated with concentration ranges of rhIL-1 $13(A)$, rhTNF $\alpha(B)$, or LPS $(C)$ in the presence of $100 \mu \mathrm{M}$ adenosine. Control cultures were incubated with rhIL-1B, rhTNF $\alpha$ or LPS alone. After a 5-h incubation period, the supernatants were collected and release of TL-6 (open bars) and IL-8 (hatched bars) was determined by ELISA. Percentage inhibition was calculated as $100 \%$ - (experimental value as $\%$ of control). Results are shown as mean $+\mathrm{SEM}$ of at least four separate experiments. ${ }^{*}$ indicates a statistically significant difference compared to activation with the lowest concentration of the specific stimulus used $(p<0.05$ by Student $t$ test). 
However, when HUVEC were stimulated with higher concentrations of IL-1B $(10 \mathrm{U} / \mathrm{ml})$, TNF $\alpha$ (1 and $10 \mathrm{ng} / \mathrm{ml})$, and LPS $(10 \mathrm{ng} / \mathrm{ml})$, a significant inhibition of IL-6 by approximately $20 \%$ was observed in the presence of $100 \mu \mathrm{M}$ adenosine, whereas release of IL-8 was inhibited by about 10 to $20 \%$ under these conditions, depending on the stimulus used. Finally, inhibition by $100 \mu \mathrm{M}$ adenosine of cytokine release by maximally activated HUVEC, ranged from $29.3 \pm 5.3 \%$ to $42.2 \pm 4.7 \%$ for IL 6 , and from $17.4 \pm 2.4 \%$ to $27.2 \pm 6.3 \%$ for IL-8.

After having established that the effects of adenosine on cytokine release were most pronounced when HUVEC were maximally activated, we determined the effects of a 10 to $250-\mu \mathrm{M}$ concentration range of adenosine under such conditions (Figures $4.2 \mathrm{~A}$ and $4.2 \mathrm{~B}$, solid circles). During coincubation with 10 $\mu \mathrm{M}$ adenosine, no significant effects on the release of IL- 6 and IL- 8 by $I L-1 B-$ activated HUVEC occurred as compared to control cultures without adenosine. While $10 \mu \mathrm{M}$ adenosine was also without effect on LPS-induced IL-8 release, it significantly increased IL-6 release by $15.1 \pm 5.3 \%$ during stimulation with endotoxin ( $p<0.05$ vs. LPS-treated controls without adenosine by Wilcoxon signed rank test). However, at higher concentrations adenosine dosedependently reduced release of both cytokines. At the highest concentration of adenosine used, the release of $\mathrm{IL}-6$ was inhibited by approximately $50 \%$, whereas release of IL-8 by IL-1B- and LPS-activated HUVEC was diminished by $29.9 \pm 4.3 \%$ and $16.0 \pm 5.7 \%$, respectively. Pretreatment with $100 \mu \mathrm{M}$ of adenosine did not enhance the inhibitory effects on cytokine release by activated HUVEC in comparison with the effects observed when cells were cotreated with adenosine during activation by inflammatory stimuli (data not shown). To rule out the possibility that the observed inhibitory effects were due to cellular toxicity of adenosine, particularly at higher concentrations, viability was tested in several ways. Coincubation with adenosine up to $250 \mu \mathrm{M}$ did not alter the normal cobblestone appearance of the activated endothelial monolayers, nor did it affect trypan blue exclusion (data not shown). Furthermore, cellular integrity was maintained in the presence of $250 \mu \mathrm{M}$ adenosine as determined by MTT test. Because endothelial cells are a rich source of the enzyme adenosine deaminase $(21,22)$, which degrades adenosine into its metabolite inosine, we investigated whether the observed inhibitory effects of adenosine were limited by endogenous adenosine deaminase activity. To this end, two inhibitors of adenosine deaminase, EHNA and dCF, were used. 
Figure 4.2 Effects of adenosine and receptor-specific adenosine analogues on rhLL-1/B- (A and $B$ ) and LPS-induced (C and D) cytokine release
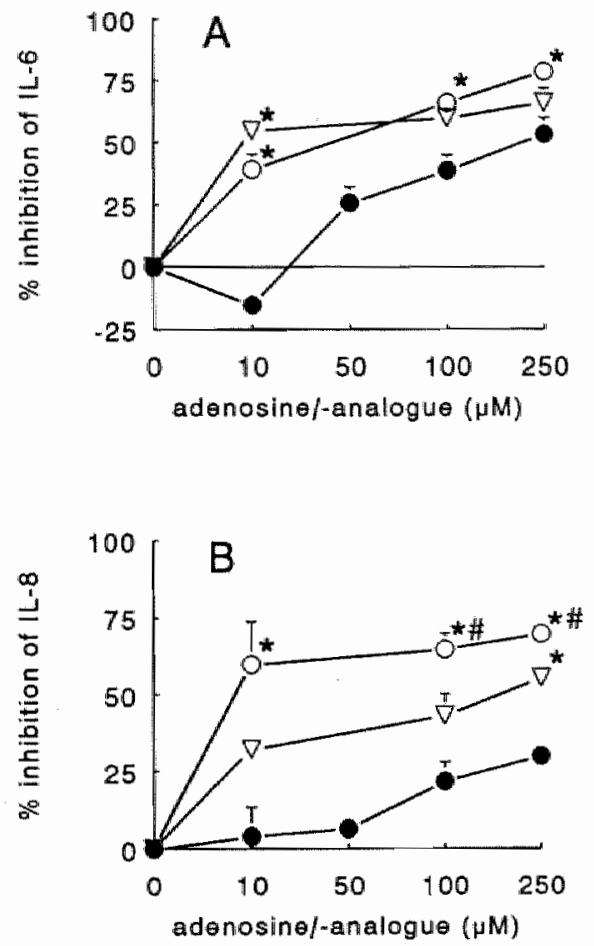
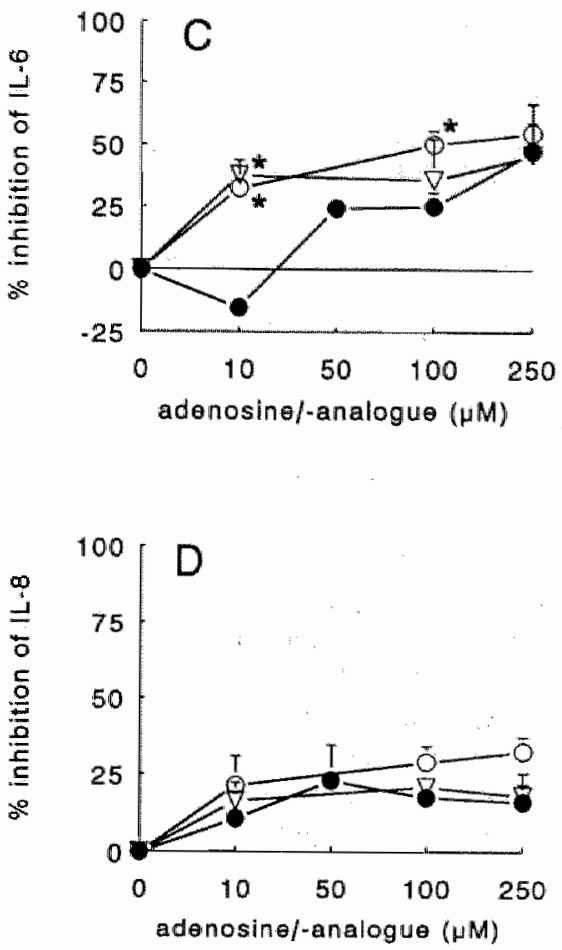

HUVEC were incubated with rhL $-18(100 \mathrm{U} / \mathrm{ml})$ or LPS $(100 \mathrm{ng} / \mathrm{ml})$ and a concentration range of either adenosine (-), 2-CAdo (O), or CPA ( $\nabla)$ for $5 \mathrm{~h}$. Control cultures were incubated with rhL-1B or LPS allone. The supernatants were collected and cytokine release was determined by ELISA. Control levels for rhIL-1B-induced cytokine release were $21.4 \pm$ $1.8 \mathrm{ng} / \mathrm{ml}$ for $\mathrm{LL}-6$ and $26.5 \pm 2.1 \mathrm{ng} / \mathrm{ml}$ for IL-8. Control levels for L.PS-induced cytokine release were $2.6 \pm 0.2 \mathrm{ng} / \mathrm{m}$ l for $\mathrm{LL}-6$ and $6.4 \pm 1.7 \mathrm{ng} / \mathrm{ml}$ for $\mathrm{IL}-8$. Percentage inhibition was calculated as $1.00 \%$ - (experimental value as \% of control). Results are shown as mean \pm SEM of five cultures. Error bars are omitted if they fall within the symbol. * indicates a statistically significant difference compared with adenosine, H indicates a statistically significant difference companed with CPA ( $p<0.05$ by one-way ANOVA). 
Tablle 4.1 Effects of ADA-inhibitors on cytokine release by activated HUVEC

\begin{tabular}{|c|c|c|c|c|}
\hline \multirow[b]{2}{*}{ Treatment } & \multicolumn{2}{|c|}{ IL $-6(\%$ Inhibition $)$} & \multicolumn{2}{|c|}{ IL-8 (\% Inhibition) } \\
\hline & Control & $100 \mu \mathrm{M}$ Ado & Control: & $1.00 \mu \mathrm{M}$ Ado \\
\hline$[\mathbb{L}-] B$ & - & $40.5 \pm 2.6$ & - & $21.6 \pm 6.3^{*}$ \\
\hline $\mathrm{I}-1 B+\mathbb{E} H \mathrm{NA}$ & $39.1 \pm 2.3^{4}$ & $83.3=1.9^{*+t}$ & $33.8 \pm 1.3^{\circ}$ & $77.4 \pm 1.2^{* i i}$ \\
\hline$I L-1 B+d C F$ & $23.6 \pm 10.9$ & $81.0=1.6^{* 4 i}$ & $12.3 \pm 4.8$ & $72.9 \pm 2.6^{*}$ \\
\hline TNF $\alpha$ & $\ldots$ & $27.6 \pm 4.1^{\circ}$ & - & $23.7 \pm 5.3^{*}$ \\
\hline TNFa + EHNA & $20.5 \pm 4.5^{*}$ & $69.1 \pm 12.5^{* / f}$ & $15.8 \pm 7.5$ & $72.5 \pm 2.4^{*}$ \\
\hline $\mathrm{TNF} \alpha+\mathrm{dCF}$ & $10.3 \pm 5.1$ & $68.2 \pm 16.7^{*}$ & $15.0 \pm 4.6$ & $61.9 \pm 12.3^{\text {wit }}$ \\
\hline
\end{tabular}

"HUVEC were stimulated with rhlL-1 $3(100 \mathrm{U} / \mathrm{ml})$ or $\mathrm{rbTNF} \alpha(100 \mathrm{ng} / \mathrm{ml})$ in the absence (control) or presence of $100 \mu \mathrm{M}$ adenosine (Ado) with or without $10 \mu \mathrm{M}$ EHNA or $10 \mu \mathrm{M}$ dCF. After an incubation period of $20 \mathrm{~h}$, supernatants were collected and release of IL- 6 and IIL- 8 was determined by ELISA. Control levels for rhIL-1B-induced cytokine release were $281.4 \pm 14.4 \mathrm{ng} / \mathrm{ml}$ for IL-6 and $593.6 \pm 63.4 \mathrm{ng} / \mathrm{ml}$ for IL-8. Control levels for rhTNF $\alpha-$ induced cytokine release were $17.6 \pm 1.5 \mathrm{ng} / \mathrm{ml}$ for $\mathbb{I L}-6$ and $311.0 \pm 42.3 \mathrm{ng} / \mathrm{ml}$ for IL -8 . ${ }^{b}$ Percentage inhibition was calculated as $100 \%$ - (experimental value as \% of control). Data are expressed as mean \pm SEM of three separate experiments. * indicates a statistically significant difference compared with the respective control cultures incubated with rhIL- $1 B$ or rhTNFa only $(p<0.05$ by Student $t$-test), \# indicates a sitatistically significant difference compared with stimulated cultures incubated with adenosine only $(p<0.05$ by Student $t$-test).

As shown in Table 4.1, addition of either $10 \mu \mathrm{M}$ EHNA or $10 \mu \mathrm{M} d C F$ dramatically enhanced the inhibitory effects of exogenous adenosine on the release of both cytokines. These results strongly indicate that there is indeed a potent endogenous adenosine deaminase activity in HUVEC, resulting in inactivation of exogenously added adenosine. To verify that degradation of exogenous adenosine was actually prevented by adenosine deaminase inhibition, adenosine levels of the supernatants were determined at several time points during a 20-hour incubation period (Figure 4.3). As shown, in the presence of $10 \mu \mathrm{M}$ EHNA adenosine levels were maintained throughout this incubation period, whereas without EHNA adenosine was rapidly degraded into inosine and hypoxanthine. Furthermore, $10 \mu \mathrm{M}$ EHNA attenuated the release of IL- 6 and IL- 8 by activated HUVEC in the absence of exogenous adenosine (Table 4.1), suggesting that endogenous adenosine can reduce cytokine release upon stimulation. This finding also indicates that adenosine and not its metabolites, such as inosine or hypoxanthine, is responsible for the observed 
inhibition of cytokine release. In line with this, coincubation of HUVEC with the adenosine metabolites inosine and hypoxanthine in concentrations up to 250 $\mu \mathrm{M}$ did not affect endotoxin or cytokine-induced cytokine release (data not shown), indicating that the inhibitory effects described above are indeed specific to adenosine.

Figure 4.3 EHNA prevents degradation of exogenous adenosine by adenosine deaminase

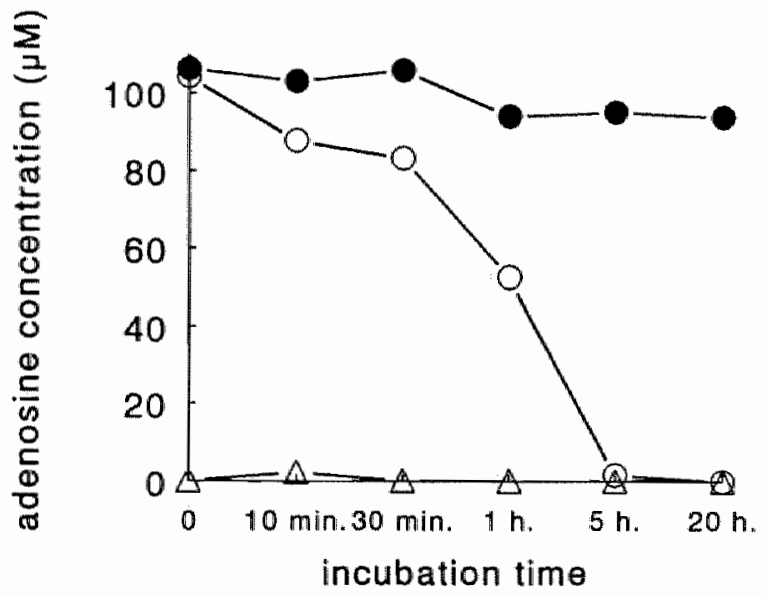

HUVEC were preincubated with (•) or without $10 \mu \mathrm{M}$ EHNA (o) for 15 min, and subsequently coincubated with $100 \mu \mathrm{M}$ adenosine and $100 \mathrm{U} / \mathrm{ml}$ m/LL-1B during 20 hours. Control cultures were preincubated with $10 \mu \mathrm{M}$ EHNA, and subsequently coincubated with $100 \mathrm{U} / \mathrm{ml} \mathrm{rhL}-1 \mathrm{~B}(\nabla)$. At the indicated time points, supernatants were collected as described in Methods, and adenosine levels were determined by HPLC.

\subsubsection{EFFECTS OF ADENOSINE ON EXPRESSION OF E-SELECTIN, ICAM-1 AND VCAM-1}

When HUVEC were stimulated with a concentration range of either TNF $\alpha$, IL$1 B$, or LPS, a dóse-dependent de novo expression of E-selectin was observed, that was maximal after $5 \mathrm{~h}$ of incubation. After an incubation period of $20 \mathrm{~h}$ expression of ICAM-1 was maximally upregulated, while VCAM-1 was maximally expressed de novo. In our hands, TNF $\alpha$ was the most potent inducer of expression of the three adhesion molecules studied, followed in order of potency by $I L-1 B$ and LPS (data not shown). 
Figure 4.4 fffects of adenosine on whNF $\alpha$-induced expression of adhesion molecules
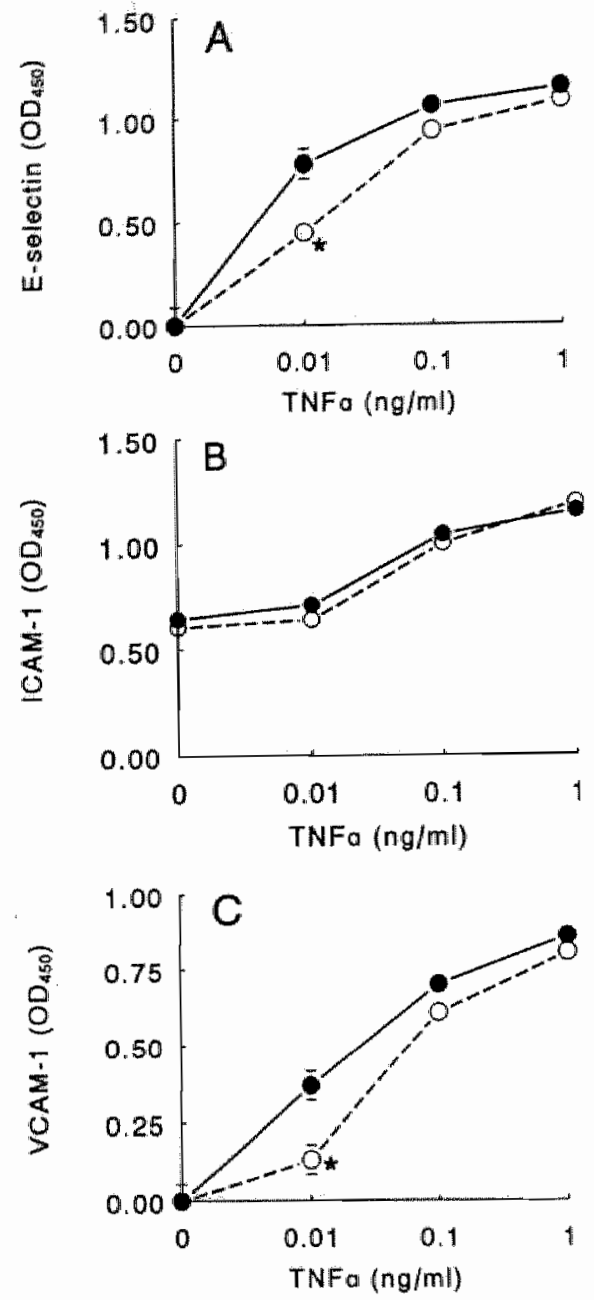

HUVEC were incubated with a concentration range of $\operatorname{rhTNF} \alpha$ in the absence ( $\bullet$ ) or presence of $250 \mu \mathrm{M}$ adenosine (O) during $5 \mathrm{~h}$ for expression of E-selectin (A) or during $20 \mathrm{~h}$ for expression of ICAM-1 $(B)$ and VCAM-1 $(C)$. At the end of the respective incubation periods, monolayers were lixed and cell surface expression of adhesion molecules was deternined by ELISA. The results of one experiment, representative of four experiments, are shown. Data are expressed as mean \pm SEM of at least four replicates. Error bars are omitted if they fall within the symbol. indicates a statistically significant difference compared with control $(p<0.05$ by Student $t$-test). 
At a concentration of $1 \mathrm{ng} / \mathrm{ml}$ of TNF $\alpha$, which induced maximal expression of the adhesion molecules, adenosine up to $250 \mu \mathrm{M}$ did not significantly inhibit expression of either of the three adhesion molecules studied (Figure 4.4). In contrast, with submaximal induction of adhesion molecules at a low TNFaconcentration of $10 \mathrm{pg} / \mathrm{ml}, 250-\mu \mathrm{M}$ adenosine attenuated the expression of $\mathrm{E}$ selectin and VCAM-1, whereas expression of ICAM-1 was not affected. Also, constitutive expression of ICAM-1 by unstimulated HUVEC was not altered by adenosine.

Figure 4.5 ADA-inhibition potentiates adenosine-mediated reduction of $I L-1 B$ and TNF $\alpha$ induced expression of E-selectin

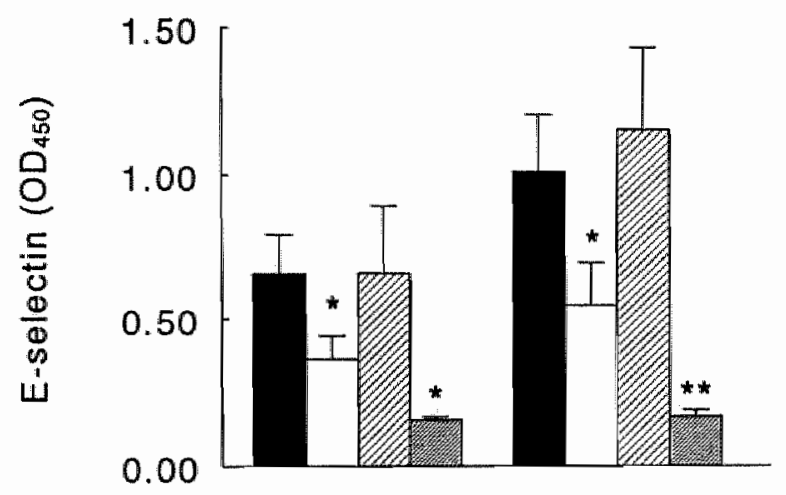

$1 \mathrm{U} / \mathrm{m} \| \mathrm{IL}-1 \mathrm{~B} \quad 10 \mathrm{pg} / \mathrm{ml} \mathrm{TNFa}$

HUVEC were preincubated with $10 \mu \mathrm{M}$ EHNA for $15 \mathrm{~min}$, and subsequently coincubated with (double-hatched bars) or without $250 \mu \mathrm{M}$ adenosine (hatched bars) and either rhlL-1B (1 $\mathrm{U} / \mathrm{ml})$ or $\mathrm{rl} T \mathrm{TNF} \alpha(10 \mathrm{pg} / \mathrm{ml})$ during $5 \mathrm{~h}$. Control cultures without EHNA were incubated with rhIL-1B or rhTNF $\alpha$ with (open bars) or without $250 \mu \mathrm{M}$ adenosine (solid bars). At the end of the incubation period monolayers were fixed and cell surface expression of E-selectin was determined by ELISA. The results of one experiment, representative of three experiments, are shown. Data are expressed as mean \pm SEM of at least six replicates. * indicates a statistically significant difference compared with controls without adenosine $(* p<0.05$ and $* * p<0.01$ by Student $t$-test)

De novo expression of E-selectin and VCAM-1 by HUVEC submaximally stimulated with $1 \mathrm{~L}-1 \beta(1 \mathrm{U} / \mathrm{ml})$ or LPS $(1 \mathrm{ng} / \mathrm{ml})$ was attenuated by adenosine to a similar extent as observed during stimulation with $10 \mathrm{pg} / \mathrm{ml}$ TNF $\alpha$, whereas 
upregulated expression of ICAM-1 was not affected by adenosine under these conditions (data not shown). In line with the effects of adenosine deaminase inhibitors on adenosine-mediated reduction of cytokine release, EHNA potentiated the inhibitory effects of exogenous adenosine on expression of Eselectin (Figure 4.5) and VCAM-1 (not shown). However, EHNA alone did not affect expression of either E-selectin, ICAM-1 or VCAM-1, indicating that endogenous adenosine levels are not sufficient to reduce induced expression of these adhesion molecules.

In line with the earlier described lack of effect on cytokine release, inosine and hyoxanthine were also without effect on the stimulated expression of either three adhesion molecules studied (data not shown).

\subsubsection{EFFECTS OF RECEPTOR-SPECIFIC ADENOSINE ANALOGUES}

Next, we sought to determine whether the observed inhibitory effects on endothelial cell activation could be related to the binding of adenosine to specific adenosine receptors. To this end, the effects on cytokine release of adenosine, the A2 receptor-specific analogue 2-CAdo and the $\mathrm{A} 1$ receptorspecific analogue CPA were compared. As shown in Figure 4.2A, 2-CAdo was significantly more potent than adenosine in reducing $I L-1 B$-induced release of IL-6 and IL-8. CPA also tended to reduce cytokine release more potently than adenosine, although statistical significance was not reached at every concentration used. However, when comparing the activities of the two analogues, 2-CAdo and CPA did not differ significantly in their potency to reduce IL-1 $\beta$-induced release of IL-6 (maximum inhibition $78.8 \pm 3.8 \%$ vs. 66.1 $\pm 6.0 \%$, respectively), whereas at concentrations of $100 \mu \mathrm{M}$ and $250 \mu \mathrm{M} 2$ CAdo was more potent than CPA in attenuating release of IL- 8 by IL- $1 \mathrm{BH}-$ activated HUVEC (maximum inhibition $69.7 \pm 4.1 \%$ vs. $55.4 \pm 1.3 \%$, respectively). Furthermore, $10-100 \mu \mathrm{M} 2$-CAdo reduced the release of IL-6 by HUVEC activated with LPS stronger than adenosine (Figure 4.2B), but was equipotent to adenosine in reducing LPS-induced IL-8. Finally, the effects of both analogues on LPS-induced cytokine release were practically identical to each other. HUVEC viability, as determined by MTT test, was always more than $95 \%$ during incubation with $10-250 \mu \mathrm{M} 2$-CAdo or CPA.

Expression of E-selectin and VCAM-1, induced by low doses of either TNF $\alpha$ $(10 \mathrm{pg} / \mathrm{ml})$, IL- $1 B(1 \mathrm{U} / \mathrm{ml})$ or LPS $(1 \mathrm{ng} / \mathrm{ml})$, was slightly more reduced by $2-$ CAdo than it was by adenosine or CPA. As an example, Figure 4.6 shows the effects of adenosine and its receptor-specific analogues on IL-1B-induced 
expression of E-selectin. In line with the data presented above, neither analogue affected constitutive or upregulated expression of ICAM-1 (data not shown).

Figure 4.6 Effects of adenosine and receptor-specific adenosine analogues on whL-1/3induced expression of E-selectin

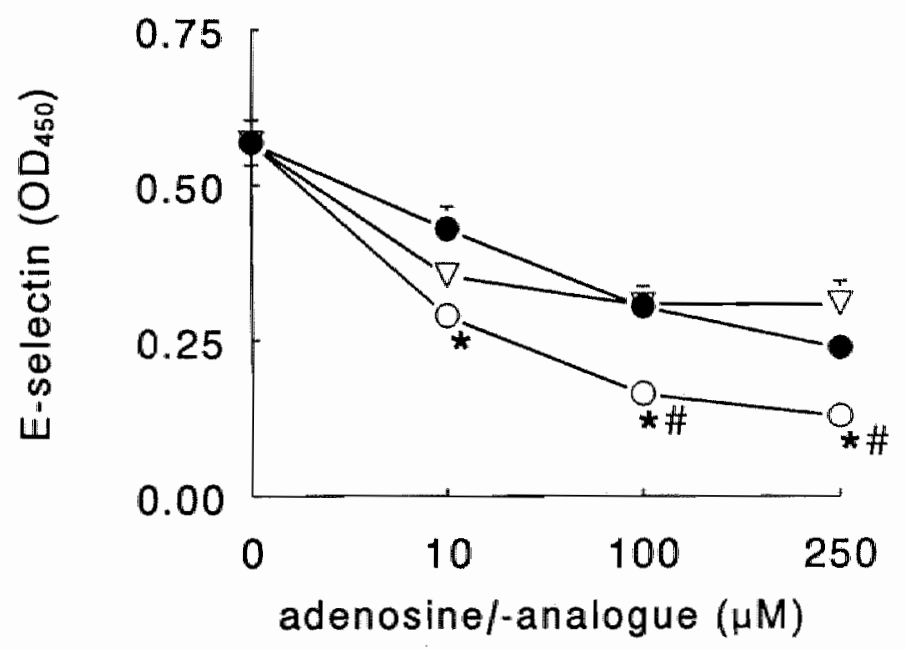

HUVEC were incubated with rhIL-1B $(1 \mathrm{U} / \mathrm{ml})$ and a concentration range of either adenosine $(\bullet)$, 2-CAdo $(O)$, or CPA $(\Delta)$ for $5 \mathrm{~h}$. At the end of the incubation period monolayers were fixed and cell surface expression of E-selectin was determined by ELISA. The results of one experiment, representative of three experiments, are shown. Data are expressed as mean \pm SEM of at least five replicates. Error bars are omitted if they fall within the symbol. All data presented differed significantly from controls incubated with rhIL-1B only $(p<0.05$ by oneway ANOVA, data not shown). * indicates a statistically significant difference compared with adenosine, \# indicates a statistically significant difference compared with CPA $(p<0.05$ by: one-way ANOVA).

\subsection{DiscussION}

During ischemia, cellular ATP is metabolized into the purine nucleosides adenosine, inosine and hypoxanthine, which accumulate in the ischemic tissue. Upon reperfusion, these metabolites are rapidly washed out by the recirculating bloodstream. It has been demonstrated that agents that enhance local tissue levels of adenosine have protective effects in various animal models of reperfusion injury or septic shock $(21,23,24)$. Although the mechanism of 
action of adenosine under these conditions has not been fully elucidated, it is thought to be related mainly to binding to specific receptors on target cells, such as vascular smooth muscle cells and PMN. Ligation of $\mathrm{A} 2$ receptors on vascular smooth muscle cells induces vasodilation (25), whereas occupancy of A2 receptors on neutrophils and mononuclear phagocytes results in inhibition of their inflammatory functions $(6,7,11,14,15,26)$. As an illustration of these receptor-mediated beneficial effects, Marts et al. (27) recently demonstrated that the $A 2$ receptor-specific adenosine analogue 2-CAdo reduced pulmonary vascular resistance as well as alveolar leukocyte influx in a rabbit model of lung ischemia reperfusion injury. While there are numerous studies in which PMN and mononuclear phagocytes have been identified as target cells for the antiinflammatory actions of adenosine or its receptor-specific analogues, thus far a direct anti-inflammatory effect of adenosine on endothelial cells has not been clearly established. In this study however, we demonstrate that adenosine does have direct inhibitory effects on two major determinants of endothelial cell activation, that is release of cytokines and de novo expression or upregulation of adhesion molecules.

First, it was demonstrated that adenosine dose-dependently inhibits release of IL-6 and IL-8 by HUVEC stimulated with either IL- $\mathbb{B}$, TNF $\alpha$ or LPS. Recently, we reported that adenosine inhibits rellease of TNF $\alpha, \mathrm{IL}-6$ and IL- 8 by LPS-activated human monocytes (14). However, maximum inhibition of endotoxin-induced endothelial cytokine release ( $47.6 \pm 11.5 \%$ for IL- 6 and 16.0 $\pm 5.7 \%$ for IL-8, Figure $4.2 \mathrm{~B}$ ) was less than the maximum inhibition we reported for endotoxin-induced IL-6 and IL-8 release by monocytes, using similar concentrations of adenosine. In this context it must be taken into consideration that, in contrast to monocytes, endothelial cells are a rich source of adenosine deaminase activity (21), resulting in degradation of adenosine into its metabolites inosine and hypoxanthine. Indeed, if endogenous adenosine deaminase activity was blocked, the inhibitory effects of exogenous adenosine on endothelial cytokine release were strongly enhanced, approaching the extent of inhibition of cytokine release by activated monocytes as reported by us earlier. In addition, this observation shows that inhibition of cytokine release is indeed specific to the actions of adenosine. Furthermore, our finding that enhancement of endogenous adenosine activity by preventing its degradation, in the absence of exogenously added adenosine, also results in inhibition of cytokine release by activated endothelial cells, points to a possible noved therapeutic potential of adenosine deaminase inhibitors to reduce inflammatory injury (24). 
For IL-1B-induced cytokine release, a discrepancy between the actions of adenosine on endothelial cells and monocytes was observed. Adenosine at a concentration of $50 \mu \mathrm{M}$ and higher attenuated the release of endothelial IL-6 and IL- 8 , whereas the release of IL- 6 and IL- 8 by monocytes was enhanced (14). Interestingly, at a relatively low concentration of $10 \mu \mathrm{M}$ of adenosine an approximately $15 \%$ enhancement of LPS-induced, but not $1 \mathrm{~L}-1 \mathrm{~B}$-induced, endothelial release of IL-6 was observed. Since it is known that submicromolar concentrations of adenosine can have a pro-inflammatory effect on PMN (7), it is conceivable that addition of $10 \mu \mathrm{M}$ exogenous adenosine resulted in an effective concentration in the submicromolar concentration range, due to the potent endogenous adenosine deaminase activity.

Second, expression of adhesion molecules was also affected by adenosine. Inhibition of E-selectin and VCAM-1 occurred only when HUVEC were submaximally activated in the presence of a relatively high concentration of 250 $\mu \mathrm{M}$ adenosine. When endogenous adenosine deaminase activity was blocked with EHNA, the inhibitory effects of adenosine on expression of E-selectin and VCAM-1 were strongly enhanced. Moreover, in the presence of EHNA, adenosine also reduced expression of both adhesion molecules induced by higher concentrations of the inflammatory stimuli. In contrast, adenosine up to a concentration of $250 \mu \mathrm{M}$ was without effect on either constitutive or upregulated expression of ICAM-1 after $20 \mathrm{~h}$ of stimulation with IL-1.B, TNF $\alpha$, or LPS. ICAM-1 expression also remained unaffected when degradation of adenosine was prevented by EHNA. Our data therefore suggest a selective inhibitory effect of adenosine on expression of E-selectin and VCAM-1. Because increased cAMP levels have been reported to selectively reduce cytokine-induced expression of both E-selectin and VCAM-1, presumably at the transcriptional level (28), it might be hypothesized that adenosine acts via a cAMP-mediated pathway to reduce expression of these adhesion molecules. Our finding that $\mathrm{A} 2$ receptor ligation by 2-CAdo which induces enhanced intracellular levels of cAMP $(7,26)$, resulted in the most potent reduction of $\mathrm{E}$ selectin and VCAM-1 as observed in this study, would be in support of this hypothesis. Recently, Jurgensen et al. (9) reported that the synthetic adenosine analogue 3-deazaadenosine inhibits biosynthesis of ICAM-1 by HUVEC stimulated with TNFa for $5 \mathrm{~h}$, whereas in our study adenosine did also not inhibit expression of ICAM-1 by cytokine-activated HUVEC after a $5 \mathrm{~h}$ incubation period (data not shown). The lack of conformity between these data possibly reflects a different mode or site of action of adenosine and 3deazaadenosine. 
Although adenosine inhibited release of cytokines, particularly of $I L-6$, when HUVEC were submaximally activated, its effect on cytokine release was most pronounced if HUVEC were maximally stimulated. In contrast, adenosine only reduced expression of adhesion molecules if HUVEC were submaximally activated. These observations lead us to hypothesize that adenosine may affect both early and more advanced stages of endothelial cell activation during the development of an inflammatory response.

In this study we were unable to demonstrate a clear role for specific adenosine receptors in mediating the inhibitory actions of adenosine. The A2 receptor-specific analogue 2-CAdo exerted significantly stronger inhibitory effects than the Al-selective analogue CPA on IL-1B-induced release of IL- 8 and expression of E-selectin and VCAM-1, but both analogues were approximately equipotent in reducing $\Pi L-1 B$-induced $I L-6$ release and LPSinduced cytokine release. Although these results would suggest a role of specific adenosine receptor ligation in mediating the inhibitory effects on endothelial cell activation, the lack of a strong evidence for this conclusion is in contrast with the well-documented receptor-specific action of adenosine on PMN and mononuclear phagocyte function. Furthermore, the concentration of adenosine required for inhibitory effects on endothelial cells seems to be relatively high in comparison to the concentrations of adenosine effective to inhibit leukocyte function. However, when the potent endogenous adenosine deaminase activity of endothelial cells was attenuated by adenosine deaminase inhibitors, the inhibitory effects of adenosine on cytokine release as well as on expression of adhesion molecules were strongly enhanced. Moreover, a role for endogenous adenosine in reducing cytokine release by activated HUVEC was demonstrated using adenosine deaminase inhibitors in the absence of exogenously added adenosine. Finally, it has been reported that local concentrations of adenosine and adenine nucleotides in the extracellular space may indeed reach the millimolar range during ischemia and shock (29), which emphasizes the possible relevance of the results obtained in this in vitro study to such clinical conditions. Taken together, our results show a clear effect of adenosine on endothelial cell function, although we were unable to define its precise mechanism of action.

The described inhibitory actions of adenosine on endothelial cell activation may be of importance in view of the role of the vascular endothelium in the pathogenesis of reperfusion injury. It has been demonstrated in various in vitro models that incubation of endothelial cells under anoxic conditions followed by reoxygenation induces increased adherence of PMN to the endothelium (30, 31). Several authors have linked the enhanced PMN-endothelial adhesion to de 
novo expression and upregulation of endothelial adhesion molecules in both in vitro models as well as in animal models of ischemia and reperfusion $(32,33)$. Furthermore, it has been demonstrated in various in vitro models, that anoxia and reoxygenation can induce the release of the pleiotropic cytokines IL-1 $\alpha, \mathrm{IL}$ 6 and the chemokine IL-8 by endothelial cells $(34,35)$, which are known to be involved in leukocyte chemotaxis and adhesion. Several authors have reported that agents that enhance local tissue levels of endogenous adenosine, either by preventing its release into the bloodstream (21) or by interfering with its metabolism $(23,24)$, provide protective effects in animal models of ischemiareperfusion or septic shock. Based on the data of this in vitro study, we propose that such protective effects may, next to the well-documented inhibitory effects of adenosine on $\operatorname{PMN}(6,7,10)$ and monocyte function $(11,14,15)$ also be the result of the inhibitory effects of adenosine on endothelial cell activation. In order to test this hypothesis, it remains to be determined whether substances that interfere with adenosine metabolism or release, will actually attenuate cytokine release and expression of endothelial adhesion molecules in experimental in vitro and in vivo models of ischemia and reperfusion.

\section{ACKNOWLEDGEMENT}

This work was supported in part by a grant from the Dr. Saal van Zwanenbergstichting.

The authors are grateful to Dr. R.A. De Abreu, Department of Pediatrics, Academic Hospital Nijmegen St. Radboud, Nijmegen, The Netherlands, for determination of adenosine levels in the culture supernatants.

\section{REFERENCES}

1. Vane JR, AngÅrd EE, Botting RM. Regulatory functions of the endothelium. $N$ Eng/ $J$ Med 323: 27-36, 1990.

2. Bradley JR, Wilks D, Rubenstein D. The vascuiar endothelium in septic shock. J Infection 28: 1.-10, 1994.

3. Mantovani $A$, Dejana E. Cytokines as communication signals between leukocytes and endothelial cells. Immunot Todoy 10: 370-375, 1989.

4. Stad RK, Burman WA. Current views on structure and function of endothelial adhesion mollecules. Cell Adhes Comm 2; 261-268, 1994.

5. Newby AC. Adenosine and the concept of retaliatory metabolites. Trends Biochem Sct $9: 42-44,1984$. 
6. Cronstein $\mathrm{BN}$, Kramer $\mathrm{SB}$, Weissman $\mathrm{G}$, Hirschhom $\mathrm{R}$. Adenosine: a physiological modulator of superoxide anion generation by human neutrophils. $J$ Exp Med 158: 1160 1. 177,1983 .

7. Cronstein BN, Levin RI, Phillips M, Hirschhom R, Abramson SB, Weissman G. Neutrophil adherence to endothelium is enhanced via adenosine $A 1$ receptors and inhibited via adenosine A2 receptors. J Immurtol 148: 2201-2206, 1992.

8. Grisham MB, Hernandez LA, Granger DN. Adenosine inhibits ischemia-reperfusioninduced leukocyte adherence and extravasation. Am J Physiol 257: H1334-H1339, 1989.

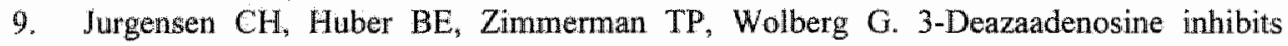
leukocyte adhesion and ICAM-1 biosynthesis in tumor necrosis factor-stimulated human endothelial cells. J Immmol 144:653-661, 1990.

10. Nolte D, Lorenzen A, Lehr H-A, Zimmer F-I, Klotz K-N, Messmer K. Reduction of postischemic leukocyte-endothelium interaction by adenosine via $\mathrm{A} 2$ receptor, Naunyn Schmiedebergs Arch Pharnocol 346: 234-237, 1992.

1. Baker AJ, Fuller RW. Elfect of cyclic adenosine monophosphate, $5^{\prime}-(N-$ ethylcarboxamido)-adenosine and methylxanthines on the release of thromboxane and lysosomal enzymes from human alveolar macrophages and peripheral blood monocytes in vitro. Eur I Pharmacol 211 : 157-161, 1992.

12. Eppell B, Newell AM, Brown EJ. Adenosine receptors are expressed during differentiation of monocytes to macrophages in vitro. J Immunol 143:4141-4145, 1989.

13. Salmon JE, Brogle N, Brownlie C, Edberg JC, Kimberly RP, Chen B-X, Erlanger BF. Human mononuclear phagocytes express adenosine $A_{1}$ receptors. J Immunol 151: 27752785, 1993.

14. Bouma MG, Stad RK, Van den Wildenberg FAJM, Buurman WA. Differential regulatory effects of adenosine on cytokine release by activated human monocytes. $J$ Immunol 153: 4159-4168, 1994.

15. Parmely MJ, Zhou W-W, Edwands III CK, Borcherding DR, Silverstein R, Morrison DC. Adenosine and a related carbocyclic nucleoside analogue selectively inhibit tumor necrosis factor- $\alpha$ production and protect mice against endotoxin challenge. I Immunol 151: 389-396, 1993.

16. Muller WA, Ratti CM, McDonnell SL, Cohn ZA. A human endothelial cell-restricted, externally disposed plasmalemmal protein enriched in intercellular junctions. I Exp Med $170: 399-414,1989$.

17. Leeuwenberg JFM, Jeunhomme GMMA, Buurman WA. Characterization of two monoclonal antibodies directed against an adhesion molecule on endothelial cells. Transplant Proc 22: 1991-1993, 1990.

18. Hansen MB, Nielsen SE, Berg K. Re-examination and further development of a precise and rapid dye method. for measuring cell growth/cell kill. I Immunol Methods 119(2): $203-210,1989$.

19. Dentener MA, Bazil V, Von Asmuth EJU, Ceska M, Buurman WA. Involvement of CD 4 in lipopolysaccharide-induced tumor necrosis factor- $\alpha$, IL-6 and IL- 8 release by human monocytes and alveolar macrophages. J Immunol 150:2885-2891, 1993.

20. Thomhill MH, Wellicome SM, Mahiouz DL, Lanchbury ISS, Kyan-Aung U, Haskard DO. Tumor necrosis factor combines with $\mathrm{IL}-4$ and IFNy to selectively enhance endothelial cell adhesiveness for $\mathrm{T}$ cells. The contribution of vascular cell adhesion 
molecule-1-dependent and -independent binding mechanisms. $J$ mmmol 146: 592-598, 1991.

21. Van Belle H. Nucleoside transport inhibition: a therapeutic approach to cardioprotection via adenosine? Cardiovasc Res 27: 68-76, 1993.

22. Smolenski RT, Kochan Z, McDouall R, Page C, Seymour A-ML, Yacoub MH. Endothellal nucleotide catabolism and adenosine production. Cardiowasc Res 28: 100$104,1994$.

23. Firestein GS, Boyle D, Bullough DA, Gruber HE, Sajadi FG, Montag A, Sambol B, Mullane KM. Protective effect of an adenosine kinase inhibitor in septic shock. $J$ Immunal 152: 5853-5859, 1994.

24. Sandhu GS, Burrier AC, Janero DR. Adenosine deaminase inhibitors attenuate ischemic injury and preserve energy balance in isolated guinea pig heart. Am $J$ Physiol 265 : H1249-H1256, 1993.

25. Collis MG. The vasodilator role of adenosine. Phamacol Ther 41: 143-162, 1989.

26. Cronstein BN. Adenosine, an endogenous anti-inflammatory agent. I Appl Physiol $76(1): 5-13,1994$.

27. Marts BC, Baudendistel LJ, Naunheim KS, Dahms TE. Protective effect of 2chloroadenosine on lung ischemia reperfusion injury. J Surg Res 54: 523-529, 1993.

28. Pober IS, Slowik MR, De Luca LG, Ritchie AJ. Elevated cyclic AMP inhibits endothelial cell synthesis and expression of TNF-induced endothelial leukocyte adhesion molecule-1, and vascular cell adhesion molecule-1, but not intercellular adhesion molecule-1. J Immunol 150: $5114-5123,1993$.

29. Gordon JL. Extracellular ATP: effects, sources and fate. Biochem J 233: 309-319, 1986.

30. Amould $T$, Michiels $C$, Remacle J. Hypoxic human umbilical vein endothelial cells induce activation of adherent polymorphonuclear leukocytes. Blood 83: 3705-3716, 1994.

31. Yoshida N, Granger DN, Anderson DC, Rothlein $R$, Lane $C$, Kvietys PR. Anoxia/reoxygenation-induced neutrophil adherence to cultured endotheliall cells. $A \mathrm{~m} \mathrm{~J}$ Physiol 262: H1891-H1898, 1992.

32. Altavilla D, Squadrito F, loculano M., Canale P, Campo GM, Zingarelli B, Caputi AP. E. sellectin in the pathogenesis of experimental myocardial ischema-reperfusion injury. $E u r$ J Pharmacol 270: 45-51, 1.994.

33. Palluy $\mathrm{O}$, Morliere $\mathbb{L}$, Gris JC, Bonne $\mathrm{C}$, Modat G. Hypoxia/reoxygenation stimulates endothelium to promote neutrophil adhesion. Free Rad Biol Med 13:21-30, 1992.

34. Ala $\mathrm{Y}$, Palluy $\mathrm{O}$, Favero J, Bonne $\mathrm{C}$, Modat $\mathrm{G}$, Domand J. Hypoxia/reoxygenation. stimulates endothelial cells to promote interleukin-1 and interleukin-6 production. Effects of free radical scavengers. Agents Actions 37: 134-139, 1992.

35. Karakurum M, Shreeniwas R, Chen J, Pinsky D, Yan S-D, Anderson M, Sunouchi K, Major J, Hamilton T, Kuwabara K, Rot A, Nowygrod R, Stem D. Hypoxic induction of interleukin-8 gene expression in human endothelial cells. J Clin Invest 93: 1564-1570, 1994. 
CHAPTER 5

Hypoxia/Reoxygenation of Cultured Human Endothelium: Effects on Cellular Activation and Adenosine Release

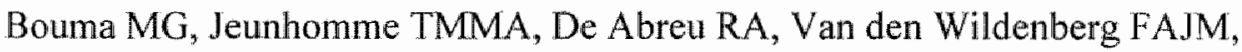
Buurman WA

Submitted for publication 


\section{ABSTRACT}

Endothelial cells have been recognized to be actively involved in promotion as well as inhibition of inflammatory processes. Specifically during ischemia and reperfusion, the vascular endothelium is the centerstage of inflammatory events that are induced by the sequence of low ambient oxygen and oxygen reintroduction. To investigate the effects of ambient oxygen on both proinflammatory and anti-inflammatory characteristics of vascular endothelium, we subjected cultured human umbilical vein endothelial cells (HUVEC) to varying periods of hypoxia and reoxygenation in an in vitro model, as the correlate of in vivo ischemia and reperfusion. Neither hypoxia for 4,8 , or $16 \mathrm{~h}$, nor subsequent reoxygenation for 5 or $20 \mathrm{~h}$, induced pro-inflammatory endothelial activation, as determined by cell-surface expression of the adhesion molecules E-selectin, vascular cell adhesion molecule-1 (VCAM-1) and intercellular adhesion molecule-1 (ICAM-1), as well as by extracellular release of the cytokines interleukin-6 (IL-6) and interleukin-8 (IL-8). At the same time however, $4 \mathrm{~h}$ hypoxia increased release of the anti-inflammatory autacoid adenosine 4-fold over normoxic control HUVEC, an event which was strongly potentiated by the adenosine kinase inhibitor GP515. We therefore conclude that hypoxia and reoxygenation per se do not promote the pro-inflammatory capacity of endothelium, but on the other hand provide a target for pharmacological interference in endothelial adenosine metabolism, thereby capitalizing on the anti-inflammatory potential of the endothelium.

\subsection{INTRODUCTION}

Ischemia followed by reperfusion is an important clinical event, occurring in various pathological situations. For instance, thrombolytic therapy after myocardial or cerebral infarction, as well as restoration of blood flow after organ transplantation or resuscitation from hypovolemic shock after trauma, are associated with the development of tissue injury and loss of organ function. There is a large body of evidence indicating that the polymorphonuclear leukocyte (PMN) is the main effector cell of the microvascular and parenchymal damage resulting from reperfusion of ischemic tissue (1). Chemotaxis and adherence of activated PMN to endothelial cells followed by transendothelial migration are crucial steps in the pathogenesis of reperfusion injury. In this respect, the endothelium is the center-stage of the inflammatory events during reperfusion. 
After appropriate stimulation, the vascular endothelium promotes the inflammatory process by releasing inflammatory mediators, such as the proinflammatory cytokines $\mathrm{LL}-1$ and $\mathrm{LL}-6$, and the chemokine $\mathrm{IL}-8$, as well as by expressing specific adhesion molecules on its cell surface, that bind and activate PMN. Endothelial activation, as originally defined by Pober (2), may be caused by pro-inflammatory cytokines, such as TNF $\alpha$ and IL-1. The involvenent of TNF $\alpha$ and $\mathbb{L L}-1$ in in wivo ischemia-reperfusion has been clearly demonstrated (3-5), and actual in vivo expression of the endothelial adhesion molecules $\mathbb{E}$ selectin (6) and ICAM-1 (7) in postischemic tissues has indeed been reported. However, while there is consensus that the vascular endothelium may be activated in vivo secondary to cytokine-stimulation during ischemiareperfusion, controversy exists with regard to the issue whether or not hypoxia and/or reoxygenation per se can directly increase the pro-inflammatory capacities of vascular endothelium. Shreeniwas et al. (8) and Karakurum et al. (9) have reported that hypoxia, but not reoxygenation, constitutes a stimulus for cultured endothelial cells to elaborate $\mathbb{I L}-1 \alpha$ and $\mathbb{L L}-8$. In contrast, others have reported that, following in vitro hypoxia, normoxic or even hyperoxic reoxygenation is required to stimulate endothelial cells to release IL-1 $(10,11)$, IL-6 (11) and IL-8 (12), suggesting that hypoxia/reoxygenation-induced intracellular oxidant stress rather than hypoxia alone triggers endothelial activation. Moreover, conflicting reports exist on the effects of hypoxia and/or reoxygenation on the induction of endothelial expression of adhesion molecules in vitro. Whereas some authors have suggested or demonstrated increased expression of E-selectin and ICAM-1 in such models $(8,10,13,14)$, others were unable to confirm this (15-19). Klein et al. (15) found no direct influence of hypoxia on endothelial expression of adhesion molecules, but suggested a priming effect.

While the activated endothelium promotes PMN adherence and activation, at the same time it can also downmodulate inflammatory reactions by releasing several anti-inflammatory molecules, such as nitric-oxide (NO) and adenosine (20-24). Whereas ischemia or prolonged hypoxia result in a reduced endothelial capacity to release $\mathrm{NO}(25,26)$, in contrast, release of adenosine by endothelial cells under such conditions is enhanced as a result of increased ATP catabolism $(27,28)$ and reduced adenosine reuptake $(29)$. During recent years, adenosine has been increasingly recognized as an important endogenous antiinflammatory agent that protects the endothelium from reperfusion injury (20). The established anti-inflammatory features of adenosine include inhibition of neutrophil superoxide release (30) and degranulation (31), reduction of cytokine release by activated monocytes (32) and endothelial cells (33), inhibition of 
neutrophil-endothelial adherence (34) and reduced endothelial expression of adhesion molecules (33). Therefore, pharmacological interference in adenosine metabolism by adenosine-regulating agents, aimed at enhancing local concentrations of endogenous adenosine, thereby capitalizing on the antiinflammatory actions of adenosine, represents a potential target for interventional strategies in various inflammatory disorders, including ischemiareperfusion injury.

The goals of the present study were twofold: first, we investigated whether in vitro hypoxia and reoxygenation directly induces human endothelial activation, as determined by release of the cytokines $I L-6$ and IL-8, and by expression of the adhesion molecules E-selectin, ICAM-1 and VCAM-1. Second, the potential therapeutic relevance of the adenosine-regulating agent GP515 to ischemia-reperfusion was assessed by determining its effect on endothelial release of the anti-inflammatory molecule adenosine during hypoxia.

\subsection{MATERIALS AND METHODS}

\subsubsection{REAGENTS}

Erythro-9-(2-hydroxy-3-nonyl)adenine (EHNA), and cyclohexamide (CHX) were obtained from Sigma Chemical (St. Louis, MO). Recombinant human $\mathrm{TNF} \alpha$ was kindly provided by BASF/Knoll (Ludwigshafen, Germany). Recombinant human IL-1ß was a kind gift of Dr. S. Gillis (Immunex, Seattle, WA). The adenosine kinase inhibitor 4-amino-1-(5-amino-5-deoxy-1-13-Dribofuranosyl)-3-bromo-pyrazolo[3,4-d]pyrimidine (GP515) was generously provided by Gensia, Inc., San Diego, CA.

\subsubsection{ENDOTHELIAL CELL CULTURE}

Human umbilical vein endothelial cells (HUVEC) were isolated from fresh human umbilical cords by collagenase treatment and were seeded into fibronectin-coated (fibronectin kindly provided by Dr. J. van Mourik, CLB, Amsterdam, The Netherlands) tissue-culture flasks (Costar, Cambridge, MA) in complete medium consisting of RPMI 1640 (Gibco, Paisley, UK) supplemented with $50 \mu \mathrm{g} / \mathrm{ml}$ heparine (Sigma Chemical Co., St. Louis, MO), $2 \mathrm{mmol} / 1$ glutamine, antibiotics, $30 \mu \mathrm{g} / \mathrm{ml}$ Endothelial Cell Growth Supplement (ECGS; Collaborative Research Inc., Bedford, MA), 10\% heat-inactivated BCS (Hyclone, Logan, UK) and 10\% heat-inactivated pooled human serum, obtained 
from healthy blood donors at the Red Cross Bloodbank Zuid Limburg (Maastricht, The Netherlands) after informed consent for research was given.

\subsubsection{HYPOXIA/REOXYGENATION MODEL}

For experiments, second or third passage HUVEC were plated onto fibronectincoated 24-well tissue-culture plates (Costar Corp., Cambridge, MA) and used when monolayers were tightly confluent. When confluent, the monolayers were rinsed twice with Endothelial Serum Free Medium (ESFM; Gibco, Paisley, UK) supplemented with $50 \mu \mathrm{g} / \mathrm{ml}$ heparin and $30 \mu \mathrm{g} / \mathrm{ml}$ ECGS, and $500 \mu 1$ medium was added to each well. The cultures were placed in a specially constructed sealed airtight hypoxia chamber $\left(2000 \mathrm{~cm}^{3}\right)$ at $37^{\circ} \mathrm{C}$, which was then flushed with a humidified $95 \% \mathrm{~N}_{2}-5 \% \mathrm{CO}_{2}$ gas mixture at a flow rate of $3000 \mathrm{ml} / \mathrm{min}_{\text {. }}$. for $10 \mathrm{~min}$ (Figure 5.1). The oxygen concentration of the atmosphere within the hypoxia chamber was measured using an oxygen analyzer (Model 570A, Servomex) and was found to drop to $0 \%$ within 10 min after initiation of gasflow. After anoxia had been achieved, the hypoxia chamber was continuously purged with the anoxic gas mixture at a flow rate of $350 \mathrm{ml} / \mathrm{min}$ for 4,8 or $16 \mathrm{~h}$. Furthermore, the oxygen concentration of the medium overlying the cells was measured on-line during anoxic incubation using a micro-oxygen electrode (Model Ml-730, Microelectrodes Inc., Londonderry, $\mathrm{NH}$ ) connected to an oxygen meter (Model OM-4, Microelectrodes Inc.). A plateau concentration of $3.5 \pm 0.1 \% \mathrm{O}_{2}$ was reached in the culture medium within 15 min after initiation of gasflow, and maintained thereafter (Figure 5.2). Special care was taken to avoid inadequate humidification of the gasmixture, since it was found in preliminary experiments that insufficient humidification lead to undesirable disturbances of medium osmolarity. To ensure that the gas mixture had been adequately humidified, the weight of the total mediumvolume was determined before and after anoxic incubation. In our experimental model, no volume-weight loss occurred during anoxia nor during control normoxic incubation (data not shown). Reoxygenation was achieved by replacing the cell cultures in a normoxic $95 \%$ room air-5\% $\mathrm{CO}_{2}$ atmosphere. With the use of the micro-oxygen electrode it was confirmed that the $\mathrm{O}_{2}$ concentration of the medium returned to a basal level of $20.9 \pm 0.1 \%$ within 25 min. To investigate whether hypoxia/reoxygenation would prime endothelial cells, in some experiments either recombinant human TNF $\alpha$ or recombinant human $I L-\beta$ dissolved in fresh culture medium was added at the beginning of the reoxygenation period. 
Figure 5.1 Experimental setup of the in wiro hypoxia/reoxygenation model

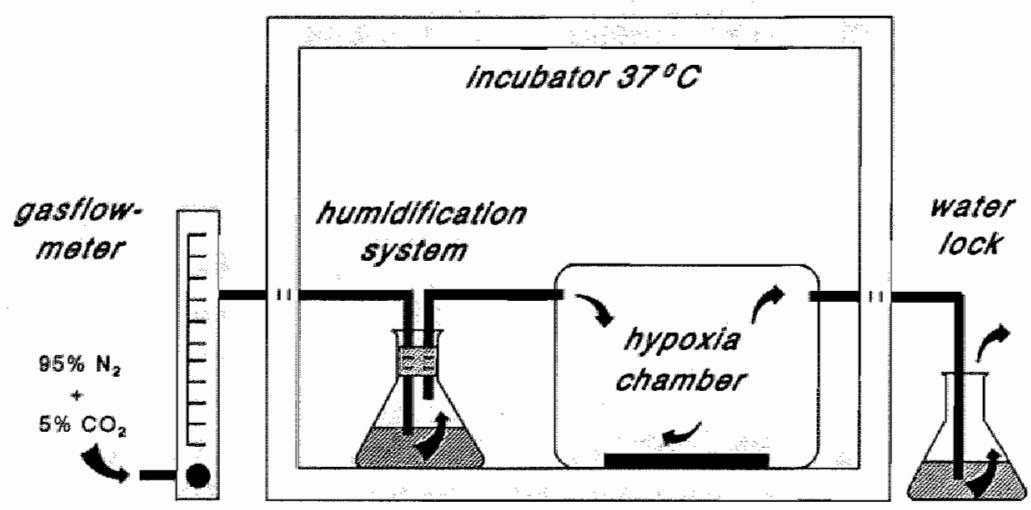

Figure 5.2 Oxygen concentration in HUVEC culture medium during in vitro hypoxialreoxygenation

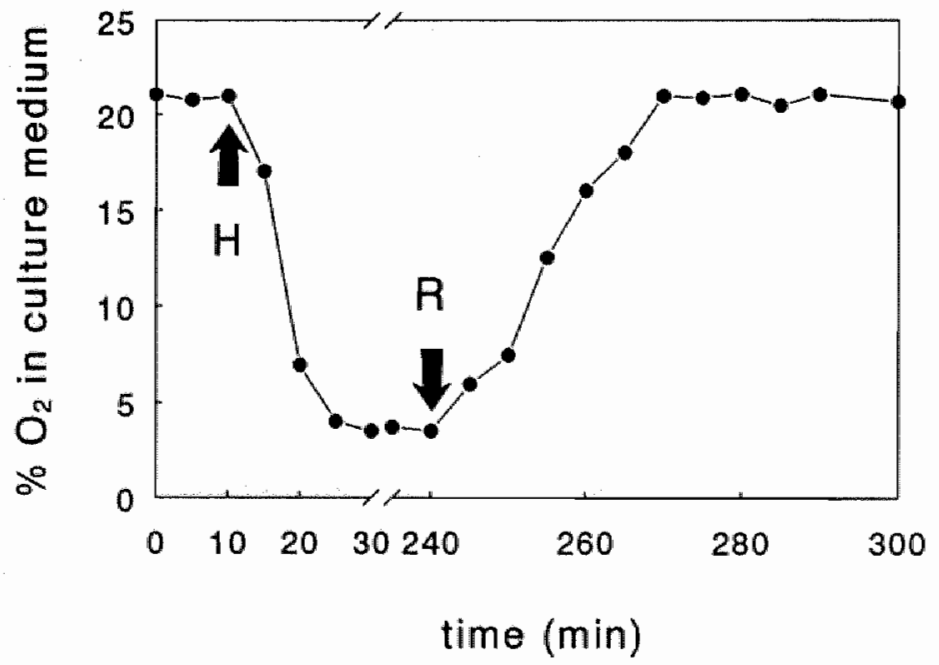

The curve represents the on-line registration of the $\mathrm{O}_{2}$ concentration in the culture medium overlying the cells during a typical hypoxia/reoxygenation experiment. At $\mathrm{T}=10 \mathrm{~min}$, hypoxia (H) was induced by purging the hypoxia chamber with a $95 \% \mathrm{~N}_{2}-5 \% \quad \mathrm{CO}_{2}$ gas mixture, reaching a plateau level of $3 \% \mathrm{O}_{2}$ within $15 \mathrm{~min}$. At $\mathrm{T}=240 \mathrm{~min}$, reoxygenation ( $\mathrm{R}$ ) to $21 \% \mathrm{O}_{2}$. was achieved within $25 \mathrm{~min}$ by replacing the culture in a $95 \%$ room air-5\% $\mathrm{CO}_{2}$ atmosphere. 


\subsubsection{ENDOTHELIAL VIABILTT, LACTATE RELEASE AND TOTAL PROTEIN SYNTHESIS}

Viability of HUVEC subjected to hypoxia and reoxygenation was tested by trypan blue exclusion test. After trypsinization, HUVEC were resuspended in ESFM, mixed with $0.2 \%$ trypan blue, and counted in a hemacytometer. Percentage viability was calculated as $100 \% \mathrm{x}$ total number of viable cells per $\mathrm{ml}$ aliquot/total number of cells per $\mathrm{ml}$ aliquot. For determination of lactate release into the culture supernatants, $200 \mu \mathrm{l}$ sample was vortexed with $20 \mu \mathrm{l}$ trichloroacetic acid (TCA; Merck, Darmstadt, Germany) 50\%, frozen in liquid nitrogen, and stored at $-80{ }^{\circ} \mathrm{C}$ until analysis. Lactate analysis was performed spectrophotometrically on a Cobas Mira S (Roche Diagnostica, Hoffiman-La Roche, Basel, Switzerland) by standard enzymatic method, using a commercially available kit as described previously by Dejong et al. (35).

To determine overall endothelial protein synthesis, incorporation of $\left[{ }^{3} \mathrm{H}\right]$ labeled phenylalanine ( $\left.\left[{ }^{3} \mathrm{H}\right]-\mathrm{Phe}\right)$ into TCA-precipitable material was measured. Upon confluency, HUVEC were rinsed twice with ESFM and $0.15 \mu \mathrm{Ci}\left[{ }^{3} \mathrm{H}\right]-\mathrm{Phe}$ in complete ESFM (specific activity $0.5 \mu \mathrm{Ci} / \mathrm{ml}$ ) was added to each well. HUVEC were subjected to either 8 or $16 \mathrm{~h}$ of hypoxia, followed by $20 \mathrm{~h}$ reoxygenation, whereas HUVEC incubated under normoxic conditions for the same time periods served as controls. At the end of the incubation period, monolayers were washed four times with ice-cold PBS supplemented with $\mathrm{Ca}^{2+}$ and $\mathrm{Mg}^{2+}, 500 \mu 110 \% \mathrm{TCA}$ at $4^{\circ} \mathrm{C}$ was added to each well and monolayers were placed on ice for $1 \mathrm{~h}$. The supernantant was removed and $500 \mu 15 \%$ TCA at $4^{\circ} \mathrm{C}$ was added for $5 \mathrm{~min}$. Finally, after removal of the supernatant, the precipitate was dissolved in $300 \mu \mathrm{l}$ of $0.3 \mathrm{~N} \mathrm{NaOH}$, after which the samples were added to scintillation fluid (Formula 989; NEN Research Products, Boston, MA) and radioactivity was counted in an automatic Liquid Scintillation System (Beckman Instruments Inc., Fullerton, CA).

\subsubsection{CELL-SURFACE EXPRESSION OF ADHESION MOLECULES}

Second or third passage HUVEC were plated onto fibronectin-coated 96-well flat-bottom cell culture plates (Costar, Cambridge, MA) in complete medium two days prior to experiments. Confluent monolayers were washed twice with complete ESFM, and subjected to normoxia or hypoxia/reoxygenation as described above. Next, HUVEC were washed three times with PBS supplemented with $\mathrm{Ca}^{2+}$ and $\mathrm{Mg}^{2+}$, fixed with $0.05 \%$ glutaraldehyde for $10 \mathrm{~min}$ at room temperature, and kept at $4^{\circ} \mathrm{C}$ until use in ELISA. Cell-surface 
expression of E-selectin, ICAM-1 and VCAM-1 was determined using previously described ELISA's (33).

\subsubsection{CYTOKINE ASSAYS}

The concentrations of the cytokines $I L-6$ and $\mathbb{I L}-8$ in the cell culture supernatants were determined using previously described sandwich-ELISA's $(32,36)$.

\subsubsection{DETERMINATION OF ADENOSINE LEVELS}

To examine the effects of hypoxia and the adenosine kinase inhibitor GP515 on endothelial adenosine release, HUVEC were incubated with $50 \mu \mathrm{M}$ of the adenosine deaminase inhibitor EHNA to prevent breakdown of endogenous adenosine by adenosine deaminase, which is abundantly present within endothelial cells (37). For determination of adenosine levels by High Performance Liquid Chromatography (HPLC), cell culture supernatants were deproteinized with $0.4 \mathrm{M}$ perchloric acid on ice, centrifuged at $12,000 \mathrm{rpm}$ for $10 \mathrm{~min}$ at $4^{\circ} \mathrm{C}$, and neutralized with $0.4 \mathrm{M} \mathrm{K}_{2} \mathrm{HPO}_{4}$. After centrifugation at $12,000 \mathrm{rpm}$ for $10 \mathrm{~min}$ at $4^{\circ} \mathrm{C}$, supernatants were kept at $-70{ }^{\circ} \mathrm{C}$ until determination of adenosine levels.

\subsubsection{STATISTICAL ANALYSIS}

All results are presented as mean \pm SEM. Differences between normoxia and hypoxia were analyzed by Student $t$-test, and were considered statistically significant at $p<0.05$.

\subsection{RESULTS}

\subsubsection{CELLULAR VIABILITY, LACTATE RELEASE AND PROTEIN SYNTHESIS}

Incubation of HUVEC under hypoxic conditions up to $16 \mathrm{~h}$ did not significantly affect trypan blue exclusion compared to normoxic controls (Table 5.1 ), nor did it alter the normal cobblestone appearance of the monolayers on microscopic examination. Moreover, after $4 \mathrm{~h}$ hypoxia, a subsequent reoxygenation period of $20 \mathrm{~h}$ did not significantly alter viability compared with HUVEC incubated under normoxic conditions for $24 \mathrm{~h}$. In contrast, a 5-h 
reoxygenation period after $16 \mathrm{~h}$ anoxia, resulted in a slight, but significant decrease in viability (Table 5.1). No apparent morphological changes, however, on microscopic examination were observed after a reoxygenation period of $20 \mathrm{~h}$, following either 4 or $16 \mathrm{~h}$ anoxia.

Table 5.1 HUVEC viability during normoxia. hypoxia, and reoxygenation

\begin{tabular}{ll}
\hline Culure conditions & $\%$ viability \\
\hline 4 h normoxia & $93.2 \pm 0.8$ \\
4h hypoxia & $92.3 \pm 0.9$ \\
4 h normoxia +20 h normoxia & $89.3 \pm 0.2$ \\
4 h hypoxia +20 h normoxia (reoxygenation) & $90.8 \pm 1.6$ \\
& \\
16 h normoxia & $88.5 \pm 1.6$ \\
16 h hypoxia & $87.7 \pm 1.0$ \\
16 h hormoxia +5 h normoxia & $88.4 \pm 0.8$ \\
\end{tabular}

Percentage viability was determined by trypan blue exclusion test as described in Materials and Methods. Results are presented as mean \pm SEM of eight experiments. * indicates a statistically significant difference compared with corresponding normoxic control $(16 \mathrm{~h}+5 \mathrm{~h}$ normoxia).

To verify that HUVEC were subjected to hypoxia, lactate production was determined as an indicator of an ischemic insult $(38,39)$. Indeed, HUVEC maintained for $4 \mathrm{~h}$ under hypoxic conditions produced approximately 350 $\mathrm{nM} /$ well lactate, whereas HUVEC maintained under normoxic conditions produced $230 \mathrm{nM} /$ well by $4 \mathrm{~h}$ (Figure 5.3 ). After $16 \mathrm{~h}$, this difference was even more pronounced with $\approx 1500 \mathrm{nM} /$ well produced during hypoxia, and $\approx 900$ $\mathrm{nM} /$ well produced during normoxia.

To assess the functional integrity of HUVEC incubated under conditions of hypoxia and reoxygenation, overall cellular protein synthesis, as determined by $\left[{ }^{3} \mathrm{H}\right]$-Phe incorporation into TCA-precipitable material, was measured. After either $4 \mathrm{~h}$ (data not shown) or $8 \mathrm{~h}$ of hypoxia (Figure 5.4), a subsequent reoxygenation period of $5 \mathrm{~h}$ did not lead to a significant decrease in overall cellular protein synthesis compared with HUVEC incubated under normoxic

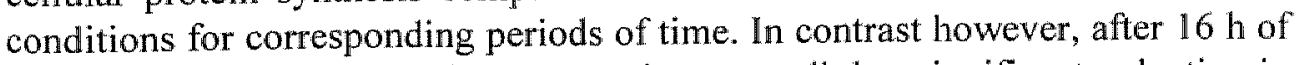
hypoxia followed by $5 \mathrm{~h}$ of reoxygenation, a small, but significant reduction in 
total protein synthesis as compared with normoxic controls was observed (21 h. normoxia: $7821 \pm 516 \mathrm{dpm} /$ well vs. $16 \mathrm{~h}$. hypoxia/ $5 \mathrm{~h}$. reoxygenation: $6410 \pm$ $271 \mathrm{dpm} /$ well, $p<0.05$ by Student $t$-test, not shown).

Figure 5.3 Lactate production by HUVEC during normoxia and hypoxia

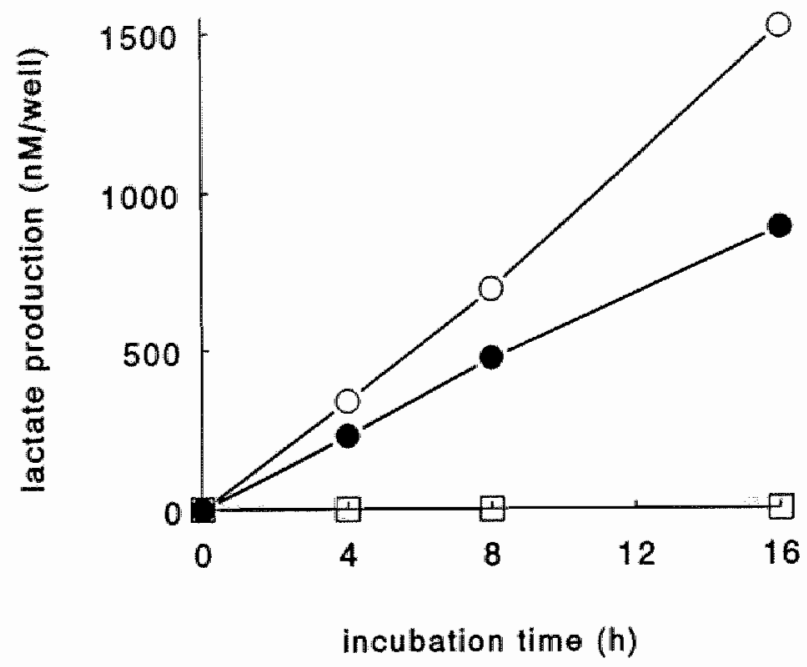

HUVEC were incubated for 4,8 or $16 \mathrm{~h}$ under either nomoxic (closed circles) or hypoxic conditions (open circles), and lactate content of the culture supernatants at the indicated timepoints was determined by HPLC. Control culture media were incubated under hypoxic conditions without the presence of HUVEC, and lactate (open squares) content was determined at the indicated timepoints. The results from a representative experiment with duplicate determinations are depicted.

\subsubsection{EXPRESSION OF ENDOTHELIAL ADHESION MOLECULES}

Unstimulated HUVEC, incubated under normoxic conditions for 4 up to $36 \mathrm{~h}$, expressed low basal levels of E-selectin and VCAM-1, whereas ICAM-1 was constitutively expressed. Hypoxia during either 4,8 or $16 \mathrm{~h}$, with or without subsequent reoxygenation for either 5 or $20 \mathrm{~h}$, did not induce de novo expression of E-selectin or VCAM-1, nor did it stimulate HUVEC to upregulate expression of ICAM-1 (Figure 5.5). 
Figure 5.4 Overall protem symthesis by HUVEC durng hypoxia and reongenation as determined by $[$ H]-Phe incorporation into TCA-precipitable material

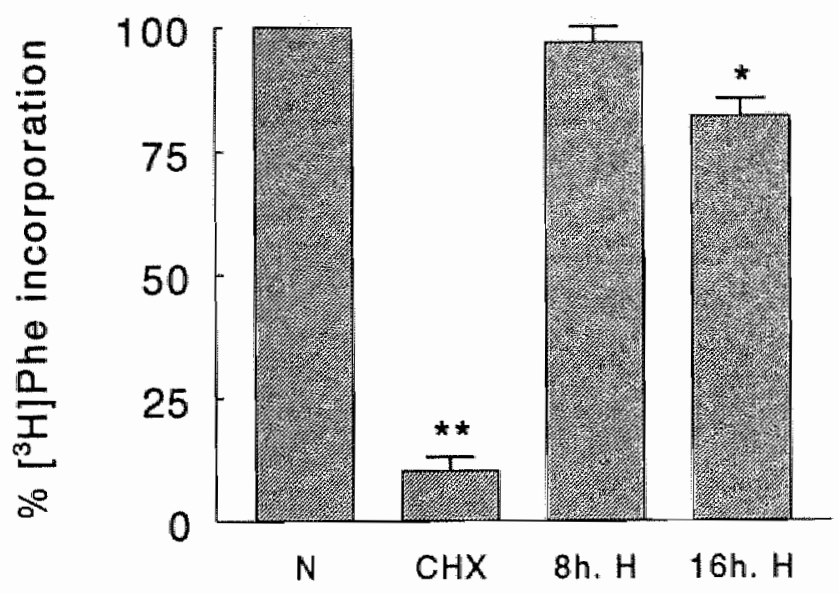

HUVEC were subjected to hypoxia $(H)$ for either 8 or $16 \mathrm{~h}$, and subsequently reoxygenated for $5 \mathrm{~h}$. [ $\left.{ }^{3} \mathrm{H}\right]$-Phe incorporation by HUVEC during hypoxia/reoxygenation was compared to that by HUVEC incubated under normoxic conditions (N) for corresponding periods of time. Normoxic HUVEC cultures incubated for $8 \mathrm{~h}$ in the presence of $5 \mu \mathrm{g} / \mathrm{ml}$ cyclohexamide (CHX) served as negative controls. Results are presented as mean + SEM of duplicate determinations of four experiments, expressed as $\%$ of normoxic controls.* indicates $p<0.05$, ** indicates $p<0.01$ compared with normoxic control cultures incubated without CHX.

To investigate whether hypoxia would prime HUVEC to express any of the adhesion molecules studied, HUVEC were stimulated with $0,1 \mathrm{ng} / \mathrm{ml} \mathrm{rhTNF} \alpha$ or $10 \mathrm{U} / \mathrm{ml}$ rhIL-1 13 upon reoxygenation. In normoxic controls stimulated at the corresponding timepoints, treatment with either TNF $\alpha$ (data not shown) or IL13 (Figure 5.5) potently induced de novo expression of E-selectin and VCAM1 , and strongly upregulated ICAM-1 expression. After hypoxia, cytokineinduced expression of either E-selectin, ICAM-1 and VCAM-I was simillar to controls, indicating that in our model hypoxia did not prime HUVEC for subsequent activation by pro-inflammatory cytokines. 
Figure 5.5 Efects of hypoxia and reoxygenation on endothelial expression adhesion molecules
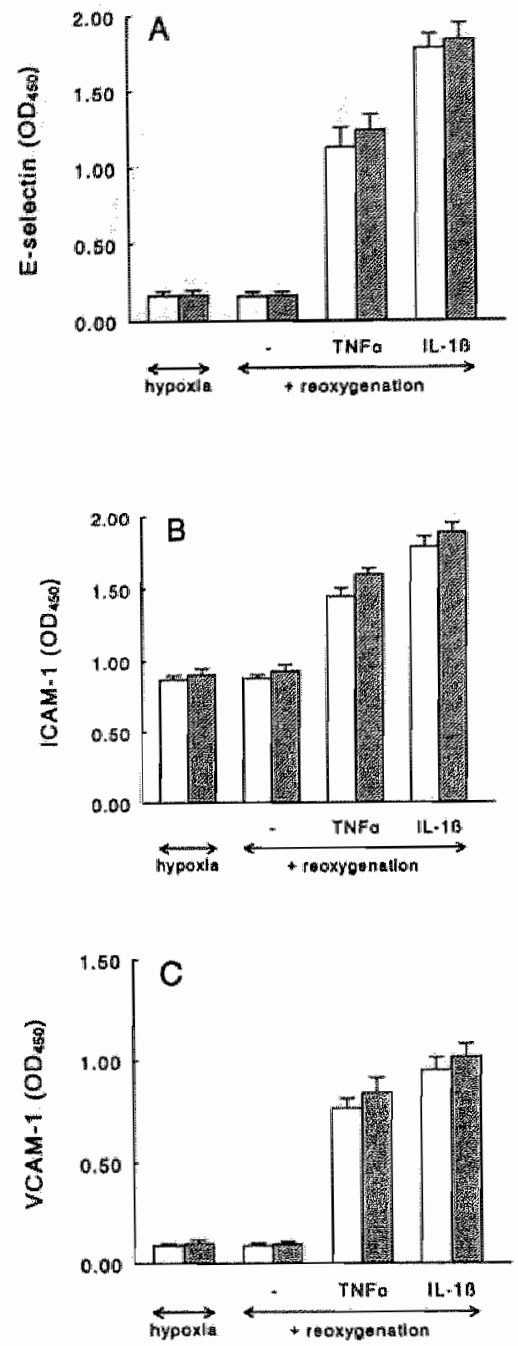

HUVEC were subjected to 4 h normoxia (open bars) or hypoxia (hatched bars). At $\mathrm{T}=4 \mathrm{~h}$, fresh medium either without activator or with $0.1 \mathrm{ng} / \mathrm{ml} \mathrm{rhTNF} \alpha$ or $10 \mathrm{U} / \mathrm{ml} \mathrm{rhlL}-\mathbb{B B}$ was added to the cultures, which were subsequently incubated under normoxic conditions for either 5 or 20 h. Cell-surface expression of E-selectin (A) was determined by ELISA at T $-4 \mathrm{~h}$ and at $\mathrm{T}=9 \mathrm{~h}$. Cell-surface expression of $1 \mathrm{CAM}-1(B)$ and VCAM-1 $(C)$ was determined by ELISA at $T=4 \mathrm{~h}$ and at $\mathrm{T}=24 \mathrm{~h}$. Results are presented as mean + SEM of quadruplicate determinations of a representative experiment. 


\subsubsection{RELEASE OF CYTOKINES}

In parallel, the release of the inflammatory cytokines IL-6 and IL-8 by HUVEC during hypoxia and reoxygenation was studied. While nomoxic HUVEC spontaneously released small quantities of both cytokines, no significant alterations in the amounts of either cytokine released into the supernatants were observed during hypoxia for either 4,8 , or $20 \mathrm{~h}$ in comparison with controls at any of the timepoints studied (Figure 5.6). Similarly, after a subsequent reoxygenation period of 5 or $20 \mathrm{~h}$ there was no significant difference in the amount of cytokine released by hypoxic and control HUVEC when hypoxia was limited to 4 or $8 \mathrm{~h}$ (Figure 5.7). This would indicate that in this setting neither hypoxia nor reoxygenation acts as a stimulus for cytokine production by endothelial cells. In contrast, after $16 \mathrm{~h}$ of hypoxia followed by reoxygenation for 5 or $20 \mathrm{~h}, \mathbb{I L}-6$ and $\mathbb{L L}-8$ levels were significantly lower than in controls (Figure 5.7), which is compatible with decreased cell viability and reduced protein synthesis capacity after such a prolonged period of hypoxia.

Analogous to the results described above for expression of adhesion molecules, hypoxia did not prime HUVEC for subsequent activation by proinflammatory cytokines to release IL-6 and IL-8. Stimulation of HUVEC with IL-1B (Figure 5.8) or TNF $\alpha$ (data not shown) after $4 \mathrm{~h}$ hypoxia resulted in release of IL- 6 and IL- 8 to levels identical to those detected after stimulation of normoxic controls. Similar results were obtained with cytokine stimulation of HUVEC after 8 or 16 h hypoxia (data not shown).

\subsubsection{RELEASE OF ADENOSINE}

As mentioned earlier, during ischemia or hypoxia cellular ATP is catabolized, resulting in enhanced release of adenosine from the cell. Since adenosine release may thus serve as a marker of ischemia $(29,37)$ we determined the adenosine levels in the culture supernatants of HUVEC subjected to hypoxia. In addition, the effects of the adenosine kinase inhibitor GP515, designed to enhance local adenosine levels during inflammatory events (40), on adenosine release under these conditions were determined. As depicted in Figure 5.9, during $4 \mathrm{~h}$ hypoxia adenosine release by HUVEC increased approximately 4 fold compared with that by HUVEC incubated under normoxic conditions for the same duration ( $4 \mathrm{~h}$ normoxia: $158 \pm 90 \mathrm{nM}$ ws. 4 h hypoxia: $640 \pm 90 \mathrm{nM}$ adenosine, $p<0.01$ by Student $t$-test), indicating that in our experimental model hypoxia was indeed achieved. 
Chapter 5

Figure 5.6 Effects of hypoxia on endothelial release of cytokines
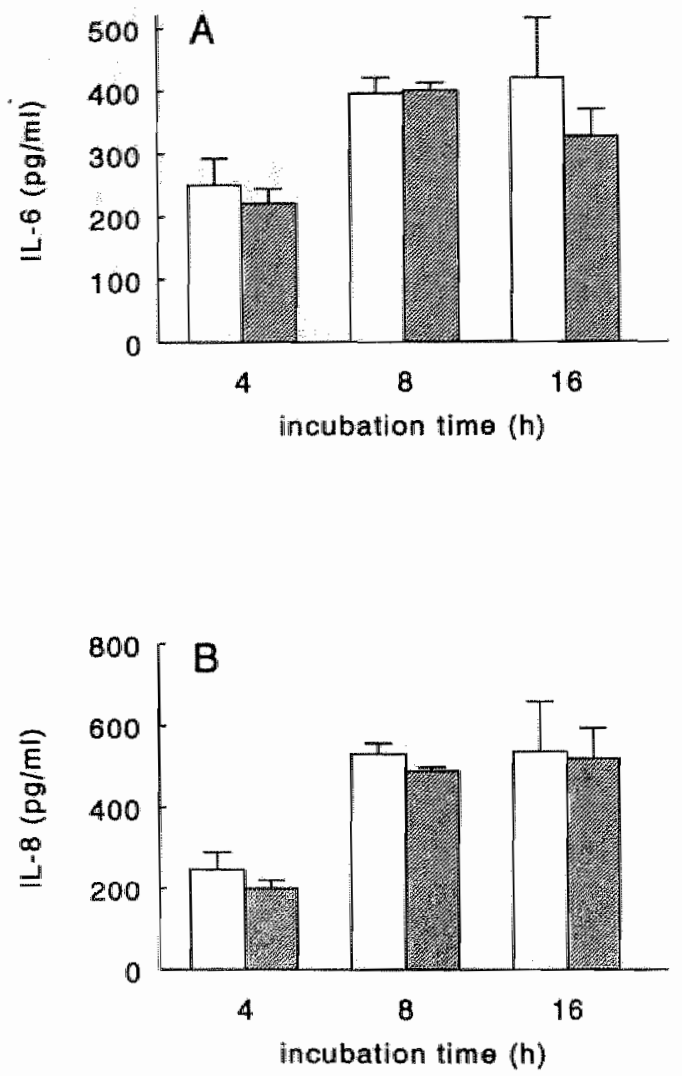

HUVEC were incubated for either 4,8 or 16 h under normoxic (open bars) or hypoxic conditions (hatched bars), and release of $I L-6(A)$ and $I L-8(B)$ into the cuiture supernatants was determined by ELISA. Results are presented as mean + SEM of duplicate determinations of four experiments. 
Figure 5.7 Effects of reoxygenation on endothelial release of cytokines
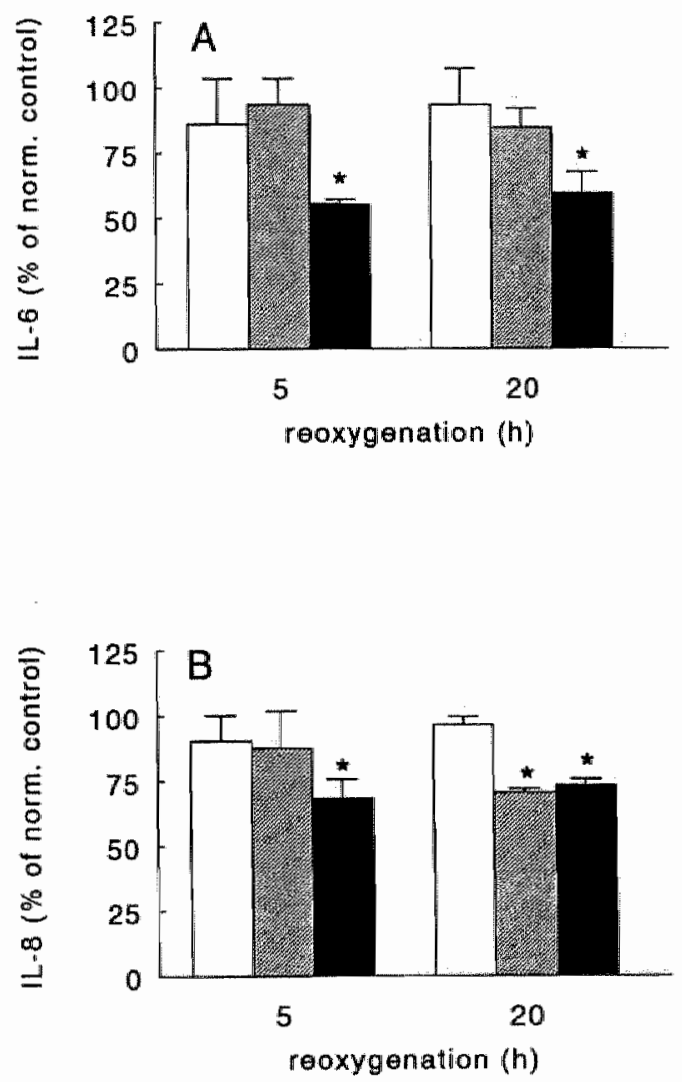

HUVEC were incubated for either 4 (open bars) 8 (harched bars), or $16 \mathrm{~h}$ (closed bars) under hypoxic conditions, and subsequently reoxygenated for either 5 or $20 \mathrm{~h}$. At the end of the incubation periods, the culture supernatants were collected and release of $I \mathrm{~L}-6(A)$ and $\mathrm{LL}-8$ $(B)$ was determined by ELISA. Results are expressed as \% of cytokine release by HUVEC incubated under normoxic conditions for corresponding periods of time, and presented as mean + SEM of duplicate determinations of at least four experiments. * indicates a statistically significant difference compared with corresponding normoxic controls. 


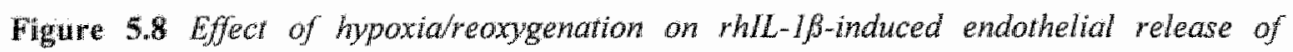
cytokines
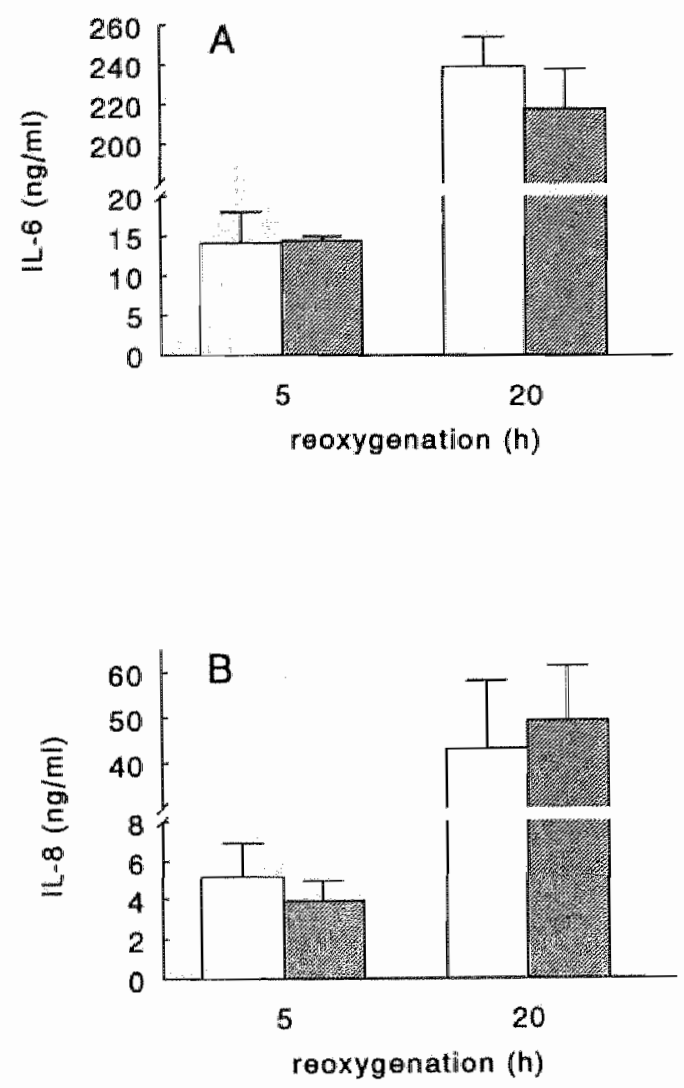

HUVE $\mathrm{C}$ were subjected to $4 \mathrm{~h}$ normoxia (open bars) or hypoxia (hatched bars). At $\mathrm{T}=4 \mathrm{~h}$, fresh nedium containing $10 \mathrm{U} / \mathrm{ml}$ rhIL-1B was added to the cultures, which were subsequently incubated under normoxic conditions for 5 or $20 \mathrm{~h}$. At the end of the incubation periods, the culture supernatants were collected and release of IL-6 (A) and IL-8 $(B)$ was determined by ELISA. Results are expressed as mean + SEM of duplicate determinations of four experiments. 
Treatment with $100 \mu \mathrm{M}$ GP515 during a 4-h incubation period dramatically enhanced endothelial adenosine release by normoxic as well as hypoxic HUVEC to $3.25 \pm 0.19 \mu \mathrm{M}$ and $5.41 \pm 0.33 \mu \mathrm{M}$, respectively, with GP515 producing an approximately 8.5 -fold increase in adenosine release by HUVEC during hypoxia.

Figure 5.9 Effects of hypoxia and GP5I5 on endothelial release of adenosime

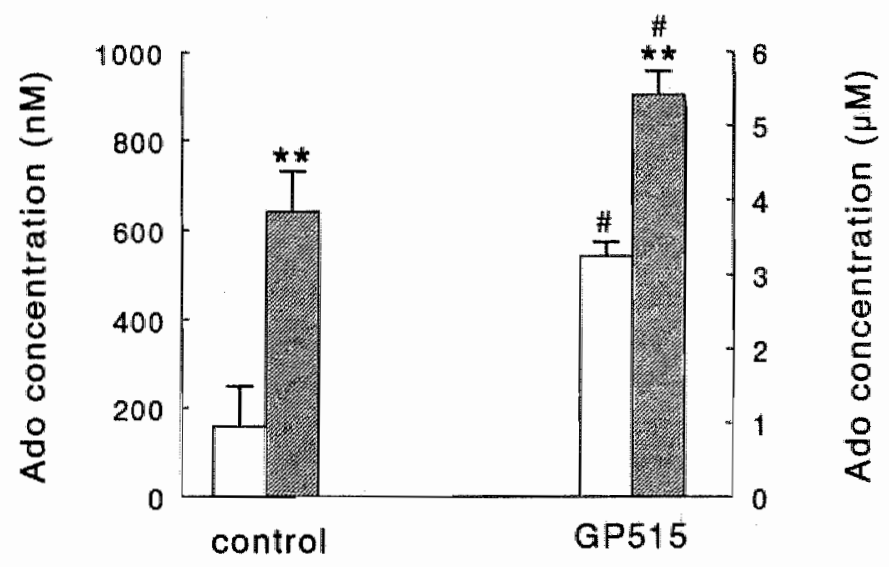

HUVEC were incubated for $4 \mathrm{~h}$ under normoxic (open bars) or hypoxic conditions (hatched bars), either without (control) or with $100 \mu \mathrm{M}$ GP515 in the presence of $50 \mu \mathrm{M}$ EHNA. Release of adenosine into the culture supernatants was determined by HPLC as described in Material and Methods. Results are presented as mean + SEM of duplicate determinations of four experiments. * indicates a statistically significant difference between normoxic and hypoxic cultures, \# indicates a statistically significant difference between untreated and GP515-treated cultures.

\subsection{DISCUSSION}

In this study, we have used an in vitro hypoxia/reoxygenation model, mimicking in vivo ischemia-reperfusion, to investigate in parallel the effects of decreased ambient oxygen on the functional integrity, the release of proinflammatory cytokines and expression of specific adhesion molecules, as well as on the release of the anti-inflammatory mediator adenosine by human endothelial cells. 


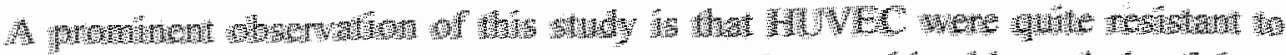

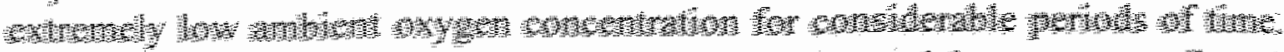

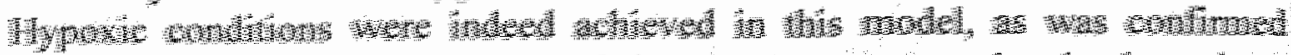

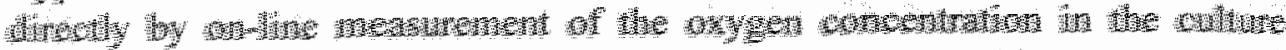

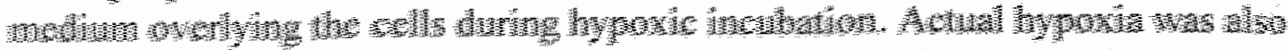

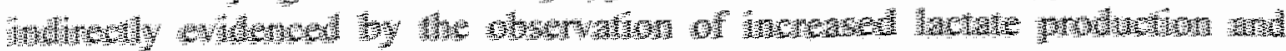

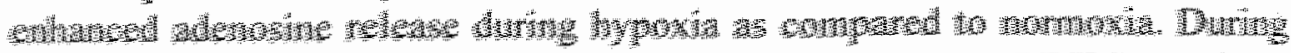

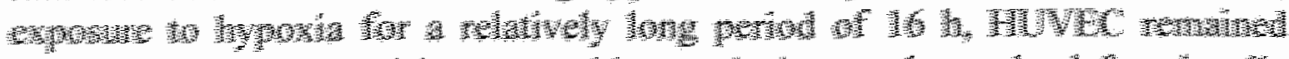

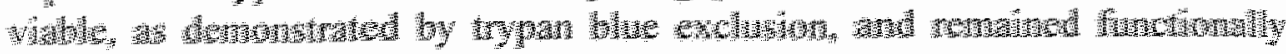

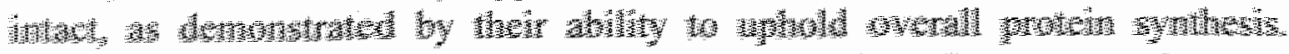

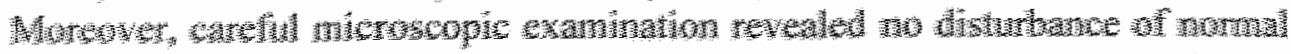

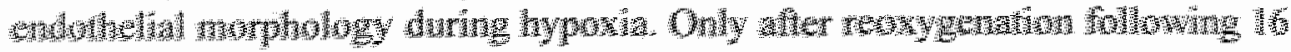

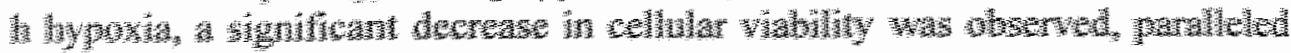

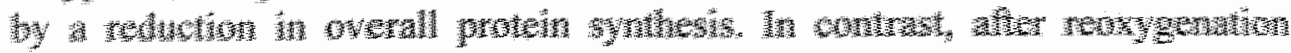

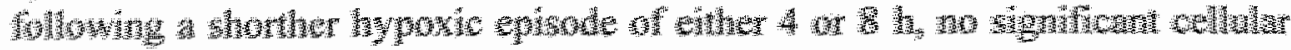

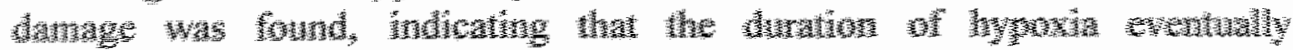

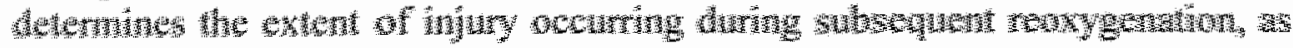

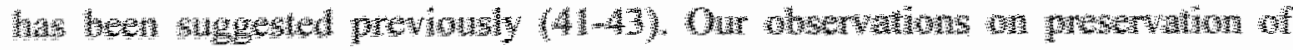

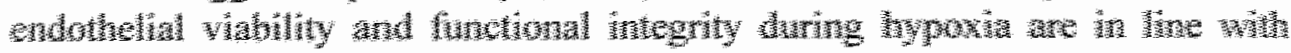

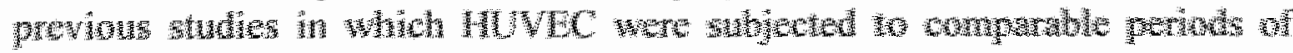

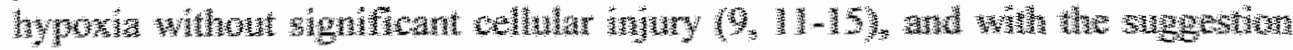

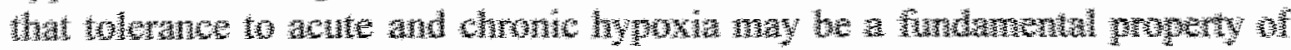
cndothelial centris (44-47).

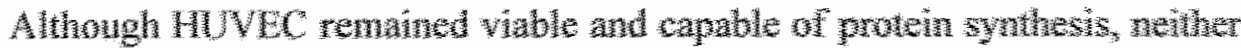

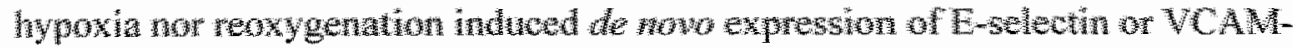
I in our model, while expression of ICAM- 1 also remained unaltered. Only few reports exist on the effects of hypoxia and reoxygenation on cell-surface expression of adhesion molecules by cultured HUVEC. There is sporadic evidence indicating that E-selectin (formerly ELAM-1) can be induced by hypoxia (14) or by reoxygenation following hypoxic treatment of HUVEC (8, $10,13)$. In two of these studies $(13,14)$, involvement of E-selectin in hypoxia/reoxygenation-induced neutrophil adherence was suggested on the basis of the kinetics and protein synthesis dependency of the endothelial surface-expressed antigen responsible for adhesion, which could be blocked by an anti-E-selectin $\mathrm{mAb}$ in one of these studies (13). In two other studies, increased presence of E-selectin during reoxygenation, but not during hypoxia, was demonstrated by Western blot analysis of lysed cells (8) and by flow cytometry (10). However, the length of the hypoxic incubations varied considerably between these studies, making comparison difficult. In the latter 
study, E-selectin was detected after 1 h hypoxia followed by 2 h reoxygenation, whereas in the former study induction of E-selectin required $16 \mathrm{~h}$ of hypoxia followed by $4 \mathrm{~h}$ reoxygenation, an experimental design which in our hands affected HUVEC viability. In contrast with these data, but in agreement with our findings, others have failed to demonstrate induction of cell-surface expression of E-selectin after hypoxia/reoxygenation of HUVEC (15-17, 19). Similarly, in the present study hypoxia nor reoxygenation induced upregulation of ICAM-1 expression by HUVEC, which is consistent with previously reported data $(15-19,48)$, but again in contrast with results from the above-mentioned studies of Shreeniwas et al. (8) and Clark et al. (10), who reported increases in ICAM- 1 in parallel with E-selectin. To our knowledge, only Klein et al. (5) have previously investigated the effects of different oxygen tensions on HUVEC expression of VCAM-1, and found no significant stimulation under hypoxic conditions, which supports our present results.

Consistent with the lack of effect of hypoxia and reoxygenation in our model on endothelial activation, as determined by the expression of adhesion molecules, we were unable to demonstrate elaboration of IL-6 and IL-8 by HUVEC under these conditions. Contrary to our findings, Ala et al. (11) reported a 2.3-fold increase of HUVEC-derived IL-6 after $5 \mathrm{~h}$ hypoxia and $19 \mathrm{~h}$ reoxygenation, compared with $24 \mathrm{~h}$ normoxia. However, it must be noted that in their study HUVEC displayed an extremely low spontaneous IL-6 production of $80 \pm 7 \mathrm{pg} / \mathrm{ml}$ during $24 \mathrm{~h}$ normoxia as detected by bioassay, whereas we detected $250 \pm 42 \mathrm{pg} / \mathrm{ml}$ IL- 6 by ELISA after $4 \mathrm{~h}$ normoxic incubation. Similarly, in contrast with our observations, Karakurum et al. (9) found a 5-fold increase of spontaneous release of IL- 8 by HUVEC during $16 \mathrm{~h}$ hypoxia compared with normoxic controls, while Strieter et al. (12) reported an approximately 2-fold increase of HUVEC-derived IL-8, which could be detected only after hyperoxic, but not normoxic, reoxygenation following 6 h hypoxia. In the latter study, a synergistic effect of hypoxia/reoxygenation and concomitant agonist stimulation was also suggested. In comparison, we stimulated HUVEC with either TNF $\alpha$ or $I L-1 B$ upon reoxygenation, but found no priming or synergistic effect of hypoxia/reoxygenation on expression of adhesion molecules or cytokine release.

Although we have currently no valid explanation for these conflicting results, they may have been caused by subtle differences in experimental designs, intrinsic HUVEC responsiveness or incubation conditions. With regard to the latter, we emphasize the importance of adequate humidification of the gas mixtures to which the cultures are exposed, since insufficient humidification causes considerable increases in culture medium osmolarity due to water loss by 
evaporation, resulting in cellular osmotic stress. While endothelial cells seem to tolerate hyperosmolarity well, even during anoxia and reoxygenation (49), osmotic stress is known to induce gene expression and protein synthesis of IL-8 $(50)$.

Our results on the release of adenosine during hypoxia, and the effects of the adenosine kinase inhibitor GP515 thereon, point to the potential therapeutic relevance of this agent, and possibly other adenosine-regulating agents, to in vivo ischemia-reperfusion events. The endothelium plays an important role in the metabolism and release of adenosine, an ubiquitous endogenous metabolite with a broad spectrum of anti-inflammatory actions (30-34). The adenine nucleotide pool in endothelial cells is two to three times greater than that seen in other cell types (37), while HUVEC seem to contain relatively high levels of ATP in comparison with other endothelial cells (38). Adenosine is generated continuously in cultured HUVEC under normal conditions, but is immediately recycled via adenosine kinase (37). During hypoxic conditions however, release of adenosine by endothelial cells is enhanced as a result of increased ATP catabolism $(27,28)$ and possibly reduced adenosine reuptake (29). Indeed, $4 \mathrm{~h}$ hypoxia in our model resulted in an approximately 4-fold increase of adenosine production by HUVEC. Moreover, inhibition of endogenous endothelial adenosine kinase activity with GP515 strongly potentiated hypoxia-induced adenosine release. These observations lead us to suggest that, given the critical importance of the vascular endothelium as the site of the inflammatory events that are induced by ischemia and reperfusion, pharmacological interference in adenosine production at the endothelial level could be useful in the treatment of reperfusion injury. Conceivably, augmentation of endothelial adenosine production could enhance the adenosine-mediated anti-inflammatory potential of the endothelium during these events. In this regard, it is of specific interest that Gunther et al. (51) recently reported the inhibition of neutrophil superoxide production by adenosine released from vascular endothelial cells.

In summary, using a well-controlled in vitro model, we have shown that human endothelial cells display considerable tolerance to hypoxia and reoxygenation. Moreover, we conclude that hypoxia/reoxygenation in itself does not constitute a direct stimulus for human endothelial cell activation, and hypothesize therefore that activation of the vascular endothelium in the in vivo setting of ischemia and reperfusion may result from indirect inflammatory mechanisms, such as enhanced release of eicosanoids, elaboration of cytokines and other pro-inflammatory mediators by monocytes or macrophages, or complement activation $(1,21)$. At the same time, the anti-inflammatory potential of the endothelium might be enforced during such events, by 
enhancing its release of the endogenous anti-inflammatory molecule adenosine, using the adenosine kinase inhibitor GP515 or other adenosine-regulating agents.

\section{REFERENCES}

1. Welbourn CRB, Goldman G, Paterson IS, Valeri CR, Shepro D, Hechtman HB. Pathophysiology of ischaemia-reperfusion injury: central role of the neutrophil. $\mathrm{BrJ}$ Surg 78: 651-655, 1991.

2. Pober JS. Cytokine-mediated activation of vascular endothelium: physiology and pathology. Am J Pathol 133: 426-433, 1988.

3. Colletti LM, Remick DG, Burtch GD, Kunkel SL, Strieter RM, Campbell Jr DA. Role of tumor necrosis factor- $\alpha$ in the pathophysiologic alterations after hepatic ischemia/reperfusion in the rat. J Clin Invest 85: 1936-1943, 1990.

4. Squadrito F, Altavilla D, Zingarelli B, loculano M, Calapai G, Campo GM, Miceli A, Caputi AP. Tumor necrosis factor involvement in myocardial ischemia-reperfusion injury. Eur J Pharmacol 237: 223-230, 1993.

5. Seekamp A, Warren JS, Remick DG, Till GO, Ward PA. Requirements for tumor necrosis factor- $\alpha$ and interleukin- 1 in limb ischemia/reperfusion injury and associated lung injury. Am J Pathol 143: 453-463, 1993.

6. Billups KL, Palladino MA, Hinton BT, Sherley JL. Expression of E-selectin mRNA during ischemia reperfusion injury. $J$ Lab Clin Med 125: 626-633, 1995.

7. Kukielka GL, Hawkins HK, Michael L, Manning AM, Youker K, Lane C, Entman ML, Smith CW, Anderson DC. Regulation of intercellular adhesion molecule-1 (ICAM-1) in ischemic and reperfused canine myocardium. $J$ Clin Inwest 92: 1504-1516, 1993.

8. Shreeniwas R, Koga S, Karakurum M, Pinsky D, Kaiser E, Brett J, Wolitzky BA, Norton C, Plocinski J, Benjamin W, Burns DK, Goldstein A, Stern D. Hypoxiamediated induction of endothelial cell interluukin-l $\alpha$ : an autocrine mechanism promoting expression of leukocyte adhesion molecules on the vessel surface. $J$ Clin Invest 90: 2333-2339, 1992.

9. Karakurum M, Shreeniwas R, Chen J, Pinsky D, Yan S-D, Anderson $M$, Sunouchi K, Major J, Hamilton T, Kuwabara K, Rot A, Nowygrod R, Stern D. Hypoxic induction of interleukin-8 gene expression in human endothelial cells. J Clin Invest 93: 1564-1570, 1994.

10. Clark ET, Desai TR, Hynes KL, Gewertz BL. Endothelial cell response to hypoxiareoxygenation is mediated by IL-1. J Surg Res 58: 675-681, 1995.

11. Ala Y, Palluy O, Favero J, Bonne C, Modat G, Dornand J. Hypoxia/reoxygenation stimulates endothelial cellss to promote interleukin-1 and interleukin-6 production. Effects of free radical scavengers. Agents Actions 37: 134-139, 1992.

12. Strieter RM, Colletti LM, Metinko A., Rolfe MW, DeMeester SR, Standiford TJ, Kunkel SL. The role of cytokine networks mediating inflammation and ischemiareperfusion injury. In: Schlag G, Redl H, Traber D (Eds.), Shock, sepsis and organ failure. Berlin: Springer Verlag, pp. 205-227, 1993. 
13. Palluy O, Morliere L, Gris JC. Bonne C, Modat G. Hypoxila/reoxygenation stimulates endothelium to promote neutrophil adhesion. Free Rad Biol Med 13:21-30, 1992.

14. Budd JM, Kirtland SJ, Baum H. Enhanced adhesion of polymorphonuclear leukocytes to anoxic cultured wascular endothelium. Cell Signal 2: 305-310, 1990.

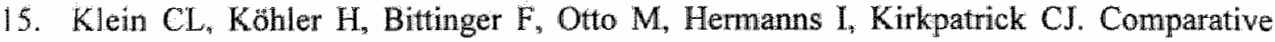
studies on vascular endothelium in vitro. 2. Hypoxia: its influences on endothelial cell proliferation and expression of cell adhesion molecules. Pathobiology 63: 1-8, 1995.

16. Yoshida N, Granger DN, Anderson DC, Rothlein R, Lane C, Kvietys PR. Anoxia/reoxygenation-induced neutrophil adherence to cultured endotheliall cells. $A m \mathrm{~J}$ Physiol 262: H1891-H1898, 1992.

17. Arnould T, Michiels $C$, Remacle J. Increased PMN adherence on endothelial cells after hypoxia: involvement of PAF, CD18/CDI1 b, and ICAM-1. Am J Physial 264: C1 102C1110, 1993.

18. Pietersma A, De Jong N, Kaster IF, Sluiter W. Effect of hypoxia on adherence af granulocytes to endothelial cells in vitro. Am J Physiol 267: H874-H879, 1994.

19. Milhoan KA, Lane TA, Bloon CM. Hypoxia induces endothelial cells to increase their adherence for neutrophils: role of PAF, Am J Physiol 263: H956-H962, 1992.

20. Cronstein BN. Adenosine, an endogenous anti-inflammatory agent. J Appl Physial 76: 5$13,1994$.

21. Kubes P. Polymorphonuclear leukocyte-endothelium interactions: a role for proinflammatory and anti-inflammatory molecules. Can J Physiol Pharmocol 71: 88-97, 1992.

22. Langrehr JM, Hoffman RA, Lancaster Jr. JR, Simmons RL. Nitric oxide: a new endogenous immunomodulator. Transplantation 55: 1205-1212, 1993.

23. Kubes P, Suzuki M, Granger DN. Nitric oxide: an endogenous modulator of leukocyte adhesion. Proc Natl Acad Sci USA 88: 4651-4655, 1991.

24. Lefer AM. Nitric oxide: nature"s naturally occurring leukocyte inhibitor. Circularion 95: $553-554$, 1997.

25. McQuillan LP, Leung GK, Marsden PA, Kostyk SK, Kourembanas S. Hypoxia inhibits expression of eNOS via transcriptional and posttranscriptional mechanisms. $A m J$ Phystol 267: H1921-H1927, 1994.

26. Ma X, Weyrich AS, Lefer DJ, Lefer AM. Diminished basal nitric oxide release after myocardial ischemia and reperfusion promotes neutrophil adherence to coronary endothelium. Circ Res 72: 403-412, 1993.

27. Zhou X, Zhai $X$, Ashraf $M$. Preconditioning of bovine endothelial cells. The protective effect is mediated by an adenosine $A_{2}$ receptor through a protein kinase $C$ signaling pathway. Circ Res 78: 73-81, 1996.

28. Nees $\mathrm{S}$, Gerbes AL, Willershausen-Zonnchen B, Gerlach E. Purine metabolism in cultured coronary endothelial cells. Adv Exp Med Biol 122B: 25-30, 1980.

29. Shryock JC, Rubio R, Berne RM. Release of adenosine from pig aontic endothelial cells during hypoxia and metabolic inhibition. Am $J$ Physiol 254: H223-H229, 1988.

30. Cronstein BN, Rosenstem ED, Kramer SB, Weissmann G, Hirschhom R. Adenosine, a physiological modulator of superoxide anion generation by human neutrophils: adenosine acts via an $\mathrm{A}_{2}$ receptor on human neutrophils. I Immunol 135: 1366-1371, 1985. 
31. Bouma MG, Jeunhomme TMMA, Boyle DL, Dentener MA, Voitenok NN, Van den Wildenberg FAJM, Buurman WA. Adenosine inhibits neutrophil degranulation in activated human whole blood. Involvement of adenosine A2 and A3 receptors. I Immunol 158: 5400-5408, 1997.

32. Bouma MG, Stad RK, Van den Wildenberg FAJM, Bumman WA. Differential regulatory effects of adenosine on cytokine release by activated human monocytes. $J$ Immunol 153:4159-4168, 1994.

33. Bouma MG. Van den Wildenberg FAJM, Bumman WA. Adenosine inhibits cytokine release and expression of adhesion molecules by activated human endothelial cells. $A m J$ Physiol 270: C522-C529, 1996.

34. Cronstein BN, Levin RI, Phillips M, Hirschhom R, Abramson SB, Weissman G. Neutrophil adherence to endothelium is enhanced via adenosine $A_{1}$ receptors and inhibited via adenosine $A_{2}$ receptors. I Immunol 148: 2201-2206, 1992.

35. Dejong CHC, Kampman MT, Deutz NEP, Soeters PB. Altered glutamine metabolism in rat portal drained viscera and hindquarter during hyperammonemia. Gastroenterology 102: 936-948, 1992.

36. Dentener MA, Bazil V, Von Asmuth EJU, Ceska M, Burman WA. Involvement of CD14 in lipopolysaccharide-induced tumor necrosis factor- $\alpha$, IL-6 and IL-8 release by human monocytes and alveolar macrophages. J Immunol 150:2885-2891, 1993.

37. Smolenski RT, Kochan Z, McDouall R, Page C, Seymour A-ML, Yacoub MH. Endothelial nucleotide catabolism and adenosine production. Cardiovasc Res 28: 100104, 1994.

38. Loike JD, Cao L, Brett J, Ogawa S, Silverstein SC, Stern D. Hypoxia induces glucose transporter expression in endothelial cells. Am J Physiol 263: C326-C333, 1992.

39. Shatos MA, Doherty JA, Stump DC, Thompson EA, Collen D. Oxygen radicals generated during anoxia followed by reoxygenation reduce the synthesis of tissue-type plasminogen activator and plasminogen activator inhibitor-1 in human endothelial cell culture. J Biol Chem 265: 20443-20448, 1990.

40. Firestein GS, Boyle D, Bullough DA, Gruber HE, Sajjadi FG, Montag A, Sambol B, Mullane KM. Protective effect of an adenosine kinase inhibitor in septic shock. $J$ Immunol 152: 5853-5859, 1994.

41. Inauen W, Granger DN, Meininger CJ, Schelling ME, Granger HJ, Kvietys PR. An in vitro nodel of ischemia/reperfusion-induced microvascular injury. Am J Physiol 259 : G134-G139, 1990.

42. Zweier JL, Kuppusamy P, Lutty GA. Measurement of endothelial cell free radical generation: evidence for a central mechanism of free radical injury in postischemic tissues. Proc Natl Acad Sci USA 85:4046-4050, 1988.

43. Ratych RE, Chuknyiska RS, Bulkley GB. The primary localization of free radical generation after anoxia/reoxygenation in isolated endothelial cells. Surgery 102: 122$131,1987$.

44. Tretyakov AV, Farber HW. Endothelial cell tolerance to hypoxia. Potential role of purine nucleotide phosphates. J Clin Invest 95: 738-744, 1995.

45. Farber HW, Rounds S. Effect of long-term hypoxila on cultured aortic and pulmonary endothelial cells. Exp Cell Res 191:27-36, 1990. 
46. Shreeniwas $R$, Ogawa $\$$, Cozzolino $F$, Torcia $G$, Braunstein $N$, Butura $C$, Brett I, Lieberman $\mathrm{HB}$, Furie $\mathrm{MB}$, Joseph-Silverstein J, Stern D. Macrovascular and microvascular endothelium during long-term hypoxia: alterations in cell growth, monolayer permeability, and cell surface coagulant properties. $J$ Cell Physiol $146: 8-17$, 1991.

47. Zimmerman LH, Levine RA, Farber HW. Hypoxia induces a specific set of stress proteins in cultured endothelial cells. J Clin Invest 87:908-914, 1991.

48. Ginis I, Mentzer SI, Faller DV. Hypoxia induces lymphocyte adhesion to human mesenchymal cells via an LFA-1-dependent mechanism. Am I Physiol 264: C617-C624, 1993.

49. Luh EH, Shackford SR, Shatos MA, Pietropaoli JA. The effects of hyperosmolarity on the viability and function of endothelial cells. J Surg Res 60: 122-128, 1996.

50. Shapiro L, Dinarello CA. Osmotic stress induces gene expression and protein synthesis of IL-8 and acts synergistically with IL- 1 or endotoxin on IL-8 synthesis. Cytokine 7: 650, 1995 (Abstract).

51. Gunther GR, Herring MB. Inhibition of neutrophil superoxide production by adenosine released from vascular endothelial cells. An $\mathrm{Fasc} \mathrm{Surg} \mathrm{5:325-330,1991.}$ 
CHAPTER 6

The Adenosine Kinase Inhibitor GP515 Attenuates Leukocyte-Endothelial Interactions in the Liver after Hemorrhagic Shock and Resuscitation in the Rat

Bauer C, Bouma MG, Herrmann I, Van den Wildenberg FAJM, Fürestein GS, Marzi I, Buurman WA American Journal of Physiology (Gastrointestinal and Liver Physiology): In press 


\section{ABSTRACT}

Adhesion of leukocytes to the vascular endothelium hallmarks a key event in neutrophil-mediated organ injury after ischemia and reperfusion. The autacoid adenosine has been shown to inhibit activated neutrophil function and to interfere with leukocyte-endothelial adherence. Its therapeutic use in ischemiareperfusion however, has been limited by severe cardiovascular side effects. We therefore investigated the effects of the adenosine kinase inhibitor GP515 on in vivo hepatic leukocyte-endothelial interactions in a rat model of hemorrhagic shock and resuscitation, using intravital microscopy. Rats were pretreated with either GP515 $(0.25 \mathrm{mg} / \mathrm{kg})$ or saline in a randomized and blinded manner, and subjected to pressure-controlled hemorrhagic hypotension at a mean arterial pressure of $40 \mathrm{~mm} \mathrm{Hg}$ during 60 minutes, followed by 5 hours of resuscitation. Five hours after resuscitation in saline-treated animals, firm leukocytesimusoidal adhesion was strongly enhanced in the periportal and midzonal sublobular regions, and also sinusoidal diameters were markedly reduced. Compared with saline-treated animals, GP515 significantly attenuated shock and resuscitation-induced leukocyte adhesion in both sublobular regions. Moreover, while GP515 did not significantly affect macrohemodynamical and hematological parameters, it also enlarged narrowed sinusoidal diameters and tended to improve sinusoidal blood flow. The anti-adhesive and microcirculatory effects of GP515 at 5 hours reperfusion were paralleled by reduced liver injury 2 days after resuscitation from shock. We propose that the adenosine-regulating agent GP515 has a therapeutic potential to attenuate ischemia-reperfusion-induced inflammation, by capitalizing on the beneficial anti-inflammatory effects of endogenous adenosine.

\section{I INTRODUCTION}

Ischemia-reperfusion injury is an important pathological event, that may result from restoration of blood circulation in a variety of serious clinical conditions, such as acute arterial obstruction, major vascular surgery, and hemorrhagic shock. Hypovolemic shock, as occurs after trauma or complex surgical procedures, followed by resuscitation, essentially represents a "whole-body" ischemia-reperfusion insult, and is clinically often associated with the development of a systemic inflammatory response syndrome and multiple organ dysfunction syndrome $(1,2)$. Central to the pathogenesis of the inflammatory response to ischemia and reperfusion is the activation of neutrophils and their 
subsequent adhesion to the vascular endothelium (3). Strategies that are aimed at attenuating the inflammatory cascades elicited during ischemia and reperfusion, include the use of anti-oxidants, PAF antagonists, anti-cytokine $\mathrm{mAbs}$, and $\mathrm{mAbs}$ directed against vascular and leukocyte adhesion molecules. During recent years however, the anti-inflammatory potential of the endogenous metabolite adenosine has become an important focus of attention of studies seeking alternative therapeutical strategies to prevent or inhibit the detrimental inflammatory response after ischemia and reperfusion. In this context, adenosine has been termed a "retaliatory metabolite" (4). The reported antiinflammatory effects of adenosine include inhibition of cytokine release (5-9), expression of endothelial adhesion molecules (6), leukocyte endothelial adhesion (10), and neutrophil function (11-13). Although numerous in vitro studies have demonstrated the anti-adhesive effects of adenosine, only few reports exist on the effects of adenosine on adhesion during postischemic conditions in vivo $(14,15)$. However, the therapeutic use of adenosine and its analogues has been limited by severe side effects, such as hypotension and bradycardia, as well as a short half life. The strategy underlying the use of adenosine-regulating agents is to enhance endogenous adenosine concentrations at local sites of inflammation, thus enhancing the beneficial anti-inflammatory effects of adenosine, while minimizing systemic toxicity. Under physiological conditions, adenosine is generated by dephosphorylation of AMP. This step is reverted by the enzyme adenosine kinase which phosphorylates adenosine to AMP. Therefore, one possibility to interfere with adenosine metabolism in order to increase endogenous adenosine levels, is to inhibit the rephosphorylation of adenosine by blocking adenosine kinase. GP515 is a novel adenosine kinase inhibitor, which anti-inflammatory actions have indeed been related to enhancement of endogenous concentrations of adenosine $(10,11,16$, 17). This compound has been reported to protect from mortality in two rodent models of septic shock without displaying systemic side effects (7). Currently however, its potential therapeutic use in ischemia-reperfusion has not been investigated. As outlined above, enhanced leukocyte-endothelial adhesion is a pivotal early step in the development of postischemic neutrophil-mediated injury of various target organs, such as the liver and the lungs (18-20). Therefore, we examined the effects of the adenosine-regulating agent GP515 on leukocyte-endothelial interactions in the liver in a rat model of hemorrhagic shock and resuscitation, using intravital microscopy as described by Marzi et al. (21). 


\subsection{MATERIALS AND METHODS}

\subsubsection{ANIMALS}

The experiments were performed using female Sprague-Dawley rats (200-250 g body weight), obtained from Charles River, Sulzfeld, Germany. The study design was approved by the local veterinarian ethics committee. Rats had free access to standard rat chow and water until the day of the experiment. The animals were anesthetized by intraperitoneal injection of pentobarbital sodium $(50 \mathrm{mg} / \mathrm{kg})$. The body temperature was maintained at $37 \pm 0.5^{\circ} \mathrm{C}$ using a temperature-controlled warming plate (Conrad Electronic, Hirschau, Germany).

\subsubsection{SURGICAL PREPARATION}

All surgical preparations were performed under aseptic conditions. Following induction of anesthesia and dermal desinfection, the rats were tracheotomized and intubated to keep the airways free and to allow spontaneous breathing. The animals were then instrumented for invasive monitoring of hemodynamical parameters as follows: the left carotid artery was cannulated with a thermistortipped $1.5 \mathrm{~F}$ catheter, which was advanced into the aortic arc for measurement of cardiac output (CO) by the transpulmonal thermodilution method (Cardiotherm 500, Columbus Instruments, Columbus, $\mathrm{OH}$ ). The right internal jugular vein was cannulated with polyethylene tubing $(0.4 \times 0.8 \mathrm{~mm}$, Portex, Hythe, UK) as a central venous access for infusion of GP515 and resuscitation fluids. The left femoral artery was cannulated with polyethylene tubing $(0.4 \mathrm{x}$ $0.8 \mathrm{~mm}$ ) for continuous invasive monitoring of the mean arterial blood pressure (MAP) and heart rate (HR) using a pressure transducer (Hellige SMK 154-9, Freiburg, Germany). This line was used for shock induction and to take blood samples for laboratory analyses (blood gas analysis by ABL, Radiometer, Copenhagen, Denmark; hematological parameters by SYSMEX 2000, Digitana, Frankfurt, Germany). Blood samples ( $300 \mu \mathrm{l} \mathrm{each)}$ were drawn at baseline, prior to shock induction, at the end of shock, and after $1 \mathrm{~h}$ and $5 \mathrm{~h}$ of resuscitation. After shock, bloodlosses due to sampling were isovolumetrically substituted with shed blood.

\subsubsection{EXPERIMENTAL GROUPS}

Animals were randomly assigned to two shock groups and two non-shock control groups, receiving either the adenosine kinase inhibitor GP515 (kindly 
provided by Gensia, Inc., San Diego, CA) or an equal amount of vehicle (saline) in a blinded manner. Thus, four experimental groups were formed ( $n=8$ each): a shock/saline group (S-S), a shock/GP515 group (S-GP), a control/saline group (C-S), and a control/GP515 group (C-GP). GP515 was administered at a dose of $0.25 \mathrm{mg} / \mathrm{kg}$ diluted in $2 \mathrm{ml}$ saline and infused intravenously during a 30-min period followed by an additional $30 \mathrm{~min}$ of steady state prior to induction of hemorrhagic hypotension. In preliminary dose-finding studies, $0.25 \mathrm{mg} / \mathrm{kg}$ infused over a $30-\mathrm{min}$ period, was found to be the critical dose to produce only a slight, non-significant initial hypotensive effect, with MAP stable thereafter. The experimental group assignment is summarized in Table 6.1. Two additional groups were investigated to examine the effects of GP515 on shock and resuscitation-induced inflammation and liver injury at two days after hemorrhagic shock and resuscitation. Animals of the 2-day shock groups ( $n=5$ each) were treated either with GP515 (2D-GP) or saline (2D-S). After two days, the serum activity of liver transaminases and organ edema were measured and compared with a time-matched sham-control group $(2 D-C)$.

Table 6.1 Experimental groups

\begin{tabular}{lllccc}
\hline Group & & $n$ & shock & treatment & reperfusion time \\
\hline C-S & (control/saline) & 8 & no & saline & $5 \mathrm{~h}$ \\
C-GP & (control/GP515) & 8 & no & GP515 & $5 \mathrm{~h}$ \\
S-S & (shock/saline) & 8 & yes & saline & $5 \mathrm{~h}$ \\
S-GP & (shock/GP515) & 8 & yes & GP515 & $5 \mathrm{~h}$ \\
& & & & & $2 \mathrm{~d}$ \\
2D-C & (control/saline) & 5 & no & saline & $2 \mathrm{~d}$ \\
2D-S & (shock/saline) & 5 & yes & saline & $2 \mathrm{~d}$ \\
2D-GP & (shock/GP515) & 5 & yes & GP515 & \\
\hline
\end{tabular}

\subsubsection{HEMORRHAGIC SHOCK AND RESUSCITATION}

After pretreatment with either GP515 or vehicle, hemorrhagic hypotension was induced within $5 \mathrm{~min}$ by blood withdrawal from the femoral arterial line, until MAP was $40 \mathrm{~mm} \mathrm{Hg}$. Shed blood was citrated to inhibit coagulation. The shock model used was pressure-controlled, i.e. if $\mathrm{MAP}$ was $>45 \mathrm{~mm} \mathrm{Hg}$, additional blood was drawn. Hypotension was maintained at $40 \mathrm{~mm} \mathrm{Hg}$ for $60 \mathrm{~min}$, and subsequently $60 \%$ of shed blood was retransfused. The animals were 
additionally resuscitated with lactated Ringer's solution with twice the shed blood volume in the first hour, once the shed blood volume in the second and third hour, and with $10 \mathrm{ml} / \mathrm{kg} / \mathrm{h}$ in the fourth and fifth hour. This resuscitation regimen was previously shown to sufficiently restore systemic circulation following hemorrhagic hypotension (22). Control animals were instrumented in an identical manner, but were not subjected to hypotension and subsequent resuscitation.

\subsubsection{INTRAVTTAL MICROSCOPY}

Five hours after the start of resuscitation from shock, or at the corresponding timepoint in control animals, the hepatic microcirculation was investigated by intravital microscopy. The abdomen was opened by a midline laparotomy, and the left liver lobe was mobilized after dissection of the hepatic ligaments. The animal was positioned onto its left side on a specially designed plexiglass stage, that allowed gentle exteriorization of the left liver lobe, with its lower plane surface uppermost. The liver surface was covered with plastic foil and continuously superfused with saline at $37^{\circ} \mathrm{C}$ to prevent desiccation. The hepatic microcirculation was then investigated using a Nikon MM-11 epifluorescence microscope (Tokyo, Japan) with a $100 \mathrm{~W}$ mercury lamp, a $545 \mathrm{~nm}$ excitation filter, a $10 \mathrm{x} / 0.30$ water immersion objective, a $0.7-2.25$ zoom objective, a $12 \mathrm{x}$ ocular, and a final magnification of $330 \mathrm{x}$. The experiments were recorded with a low-light CCD camera (FK6990, Pieper, Schwerte, Germany), which was connected through a serial time-date generator (VTG 33, FOR-A Company, Tokyo, Japan) with a SVHS video recording system (Panasonic FS-1, Tokyo, Japan). Acridine orange ( $1 \mathrm{mg} / \mathrm{ml}$ in saline; Sigma, St. Louis, MO) as fluorescence marker of leukocytes was injected i.v. as bolus of $0.1 \mathrm{mg}$ per recorded liver lobule. The microcirculation and leukocyte-endothelial interactions in five liver lobules were observed and recorded during $30 \mathrm{sec}$ for off-line evaluation. Next, five central venules were brought into the center of the image, and the pericentral region was recorded for comparable determination of sinusoidal diameters at distances of $90 \mu \mathrm{m}$ from the central vein.

Upon completion of the experiments, the livers were harvested, and wet weight was determined. Next, the organs were dried at $60^{\circ} \mathrm{C}$ for $24 \mathrm{~h}$, and weighed again, to determine wet/dry ratio as a marker of organ edema. 


\subsubsection{EVALUATION}

The recorded sequences of intravital liver microscopy were evaluated off-line by an independent observer blinded to the experimental group assignment.

Leukocyte adhesion was determined as the number of leukocytes per $\mathrm{mm}^{2}$ of liver surface for each of the three different sublobular fields of the liver acinus as described by Rappaport (23). According to recent previous studies $(21,22)$, two distinct types of leukocyte adhesion were differentiated: reversible, temporary adhesion (adhesion time: $<20 \mathrm{sec}$; mean adhesion time: $1-3 \mathrm{sec}$ ), and mostly irreversible, firm adhesion (adhesion time: $>20 \mathrm{sec}$ ).

The hepatic microcirculation was quantitated by assessment of sinusoidal diameters and estimated sinusoidal blood flow, as determined by leukocyte velocity measurements using a computer-supported morphometrical image analysis system (Lobulus, Medvis, Homburg, Germany). Flow was calculated under the assumption of circular diameters of sinusoids using the following equation: $F=v_{L} \star \pi \star\left(D_{s} / 2\right)^{2}$, where $F$ is flow, $v_{\mathrm{L}}$ is leukocyte velocity, and $D_{s}$ is sinusoidal diameter.

\subsubsection{STATISTICAL ANALYSIS}

Data are presented as mean \pm SEM. Differences between groups were tested by analysis of variance and post-hoc Student-Newman-Keuls test. Differences between various timepoints within one group were tested by paired $t$-test. A $p$ value $<0.05$ was considered statistically significant.

\subsection{RESULTS}

\subsubsection{HEMODYNAMICAL PARAMETERS}

At baseline, MAP, HR, and $\mathrm{CO}$ were identical in all experimental groups (Figures $6.1 \mathrm{~A}, 6.1 \mathrm{~B}$, and $6.1 \mathrm{C}$ ). Infusion of $0.25 \mathrm{mg} / \mathrm{kg}$ GP5 15 over a 30 -min period resulted in a moderate, non-significant reduction of MAP from $125.4 \pm$ $5.6 \mathrm{~mm} \mathrm{Hg}$ to $102.9 \pm 7.8 \mathrm{~mm} \mathrm{Hg}$ in the control group (C-GP), and from 128.9 $\pm 4.6 \mathrm{~mm} \mathrm{Hg}$ to $103.3 \pm 6.2 \mathrm{~mm} \mathrm{Hg}$ in the shock group (S-GP). Also, after infusion of GP515, MAP in both GP515-treated groups did not differ significantly from both saline-treated control groups at the corresponding timepoint ( $\mathrm{T}=30 \mathrm{~min}$ ). Similarly, i.v. administration of GP515 did not affect HR and $\mathrm{CO}$ prior to shock. 
Figure 6.1 Mean arterial blood pressure $(A)$, heart rate $(B)$, and cardiac output $(C)$ during steady state, hemorrhagic shock, and resuscitation periods
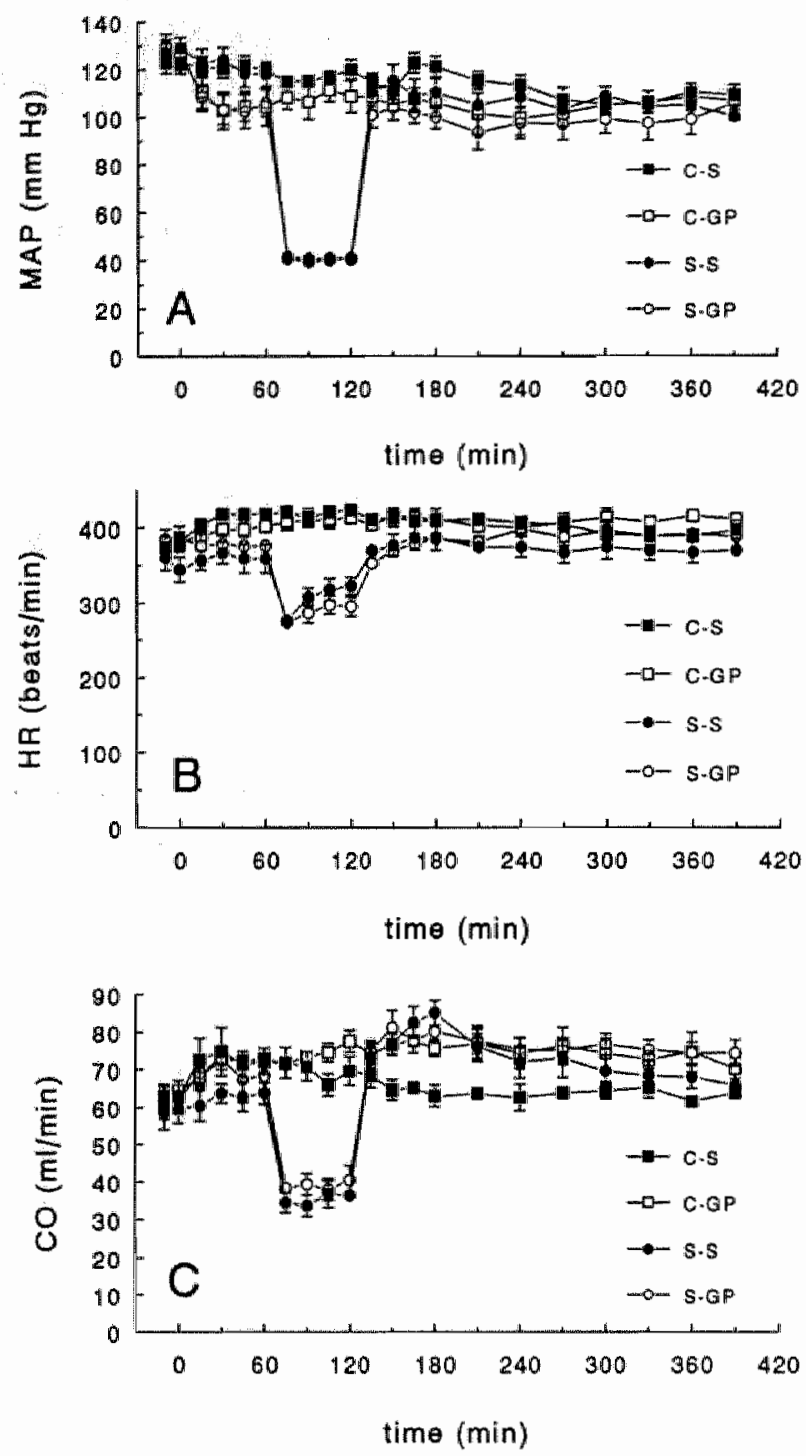
Compared with baseline, a slight, but non-significant increase in $\mathrm{CO}$ was observed during the first hour of the experiment, which was however identical in all experimental groups. Hemorrhagic hypotension was induced and maintained constantly at $40 \mathrm{~mm} \mathrm{Hg}$ during $60 \mathrm{~min}$, resulting in a reduction of HR and CO, which was the same in the saline-treated and GP515-treated group. Resuscitation completely restored shock-induced hemodynamic changes in both shock groups, with MAP, HR, and CO being identical compared with both control groups. Moreover, no significant differences in these hemodynamical parameters were observed between saline-treated and GP515-treated animals.

\subsubsection{HeMATOLOGICAL PARAMETERS}

Prior to induction of shock, $\mathrm{pH}$, blood gases, hemoglobin concentration ( $\mathrm{Hb}$ ), hematocrit (Hct), and white blood cell count (WBC), were comparable in all experimental groups (Table 6.2). Compared with the end of steady state ( $\mathrm{T}=60$ min), shock resulted in a significant elevation of $\mathrm{p}_{\mathrm{a}} \mathrm{O}_{2}$, and a reduction of $\mathrm{p}_{\mathrm{a}} \mathrm{CO}_{2}$ as well as reduced $\mathrm{Hb}$ and $\mathrm{Hct}$. These changes were not altered by pretreatment with GP515. At the end of shock, $\mathrm{p}_{\mathrm{a}} \mathrm{O}_{2}, \mathrm{p}_{\mathrm{a}} \mathrm{CO}_{2}, \mathrm{Hb}$ and Hct were significantly altered compared to non-shocked animals. During reperfusion, no significant differences with regard to these parameters were observed between any of the experimental groups. Neither in control animals nor in shock animals, did GP515 affect any of the hematological parameters determined.

\subsubsection{LIVER WET/DRY RATIO AND TRANSAMINASES}

Liver wet dry/weight ratio's revealed no differences between all experimental groups at $5 \mathrm{~h}$ after shock (data not shown). However, at 2 days after shock, a significant increase in liver wet/dry ratio was observed in the shock-control group, which could be prevented by GP515 (Figure 6.2A). Moreover, at this timepoint, the shock-induced increase of serum activity of the transaminase AST was significantly reduced in the GP515-treated group (Figure 6.2B).

\subsubsection{LEUKOCYTE ADHESION}

Five hours after resuscitation from shock, or at the corresponding timepoint in control animals, temporary leukocyte adhesion was identical in treated as well as untreated control and shock groups, ranging from $8.6 \pm 0.7 \%$ to $9.7 \pm 0.5 \%$ of the total number of sinusoidal leukocytes, and displayed no differences between the various sublobular regions (data not shown). 
Table 6.2 Hematological paraneters

\begin{tabular}{|c|c|c|c|c|c|}
\hline & $\begin{array}{l}\text { time } \\
\text { (min) }\end{array}$ & $\mathrm{C}-\mathrm{S}$ & $\mathrm{C}-\mathrm{GP}$ & $S-S$ & S-GP \\
\hline \multirow[t]{4}{*}{$\mathrm{pH}$} & 60 & $7.32 \pm 0.02$ & $7.34+0.05$ & $7.33 \pm 0.04$ & $7.33 \pm 0.03$ \\
\hline & 120 & $7.37 \pm 0.03$ & $7.36 \pm 0.04$ & $7.32 \pm 0.04$ & $7.35 \pm 0.03$ \\
\hline & 180 & $7.40 \pm 0.02$ & $7.38 \pm 0.03$ & $7.38 \pm 0.02$ & $7.39 \pm 0.03$ \\
\hline & 420 & $7.33 \pm 0.02$ & $7.33 \pm 0.01$ & $7.36 \pm 0.02$ & $7.37 \pm 0.02$ \\
\hline \multirow{4}{*}{$\begin{array}{l}\mathrm{P}_{\mathrm{is}} \mathrm{O}_{2} \\
(\mathrm{~mm} \mathrm{Hg})\end{array}$} & 60 & $70.5 \pm 6.5$ & $77.2 \pm 13.4$ & $65.7 \pm 9.8$ & $73.3 \pm 6.4$ \\
\hline & 120 & $80.2 \pm 11.6$ & $74.8 \pm 10.9$ & $107.9 \pm 14.2^{34}$ & $105.2 \pm 16.6^{*}$ \\
\hline & 180 & $84.1 \pm 6.3$ & $83.0 \pm 18.7$ & $68.5 \pm 6.5$ & $77.4 \pm 6.7$ \\
\hline & 420 & $108.1 \pm 8.2$ & $101.5 \pm 11.6$ & $99.7 \pm 10.5$ & $110.1 \neq 12.4$ \\
\hline \multirow{4}{*}{$\begin{array}{l}\mathrm{p}_{\mathrm{it}} \mathrm{CO}_{2} \\
(\mathrm{~mm} \mathrm{Hg})\end{array}$} & 60 & $32.5 \pm 4.3$ & $32.0 \pm 5.1$ & $38.2 \pm 9.3$ & $35.2 \pm 6.1$ \\
\hline & 120 & $31.0 \pm 4.3$ & $31.1 \pm 5.8$ & $21.4 \pm 5.2^{4}$ & $23.2 \pm 6.5^{*}$ \\
\hline & 180 & $28.8 \pm 4.4$ & $31.11 \pm 2.9$ & $32.3 \pm 4.9$ & $30.1 \pm 3.2$ \\
\hline & 420 & $37.8 \pm 6.9$ & $34.3 \pm 5.9$ & $39.2 \pm 1.6$ & $33.5 \pm 9.4$ \\
\hline \multirow{4}{*}{$\begin{array}{l}\mathrm{Hb} \\
(\mathrm{mmol} / \mathrm{l})\end{array}$} & 60 & $6.6 \pm 0.7$ & $6.7 \pm 0.6$ & $6.4 \pm 0.6$ & $6.6 \pm 0.4$ \\
\hline & 120 & $6.3 \pm 0.5$ & $6.5+0.6$ & $3.9 \pm 0.6^{6 n}$ & $4.1 \pm 0.4^{* i t}$ \\
\hline & 1.80 & $6.0 \pm 0.4$ & $6.1 \pm 0.6$ & $5.0 \pm 0.2$ & $5.1 \pm 0.4$ \\
\hline & 420 & $6.5 \pm 0.6$ & $6.4 \pm 1.1$ & $5.2 \pm 0.8$ & $5.3 \pm 0.4$ \\
\hline \multirow{4}{*}{$\begin{array}{l}\text { Het } \\
(\%)\end{array}$} & 60 & $29.7 \pm 2.6$ & $30.5 \pm 1.9$ & $29.6 \pm 2.1$ & $30.5 \pm 1.9$ \\
\hline & 120 & $29.5 \pm 2.0$ & $29.4 \pm 1.9$ & $19.6 \pm 2.6$ & $19.8 \pm 1.8^{*}$ \\
\hline & 180 & $27.2 \pm 1.7$ & $27.9 \pm 2.2$ & $23.9 \pm 1.3$ & $24.0 \pm 1.5$ \\
\hline & 420 & $29.2 \pm 2.6$ & $28.3 \pm 4.1$ & $24.8 \pm 3.4$ & $24.8 \pm 1.7$ \\
\hline \multirow{4}{*}{$\begin{array}{l}\text { WBC } \\
\left(\times 10^{\%} / 1\right)\end{array}$} & 60 & $5.2 \pm 2.3$ & $5.5 \pm 1.4$ & $4.5 \pm 1.1$ & $4.7 \pm 1.9$ \\
\hline & 120 & $6.8+3.1$ & $5.7 \pm 1.2$ & $3.9 \pm 1.1$ & $4.0 \pm 1.2$ \\
\hline & 180 & $6.2 \pm 2.3$ & $5.7 \pm 1.3$ & $4.5 \pm 1.3$ & $4.2 \pm 1.0$ \\
\hline & 420 & $7.4 \pm 1.5$ & $6.5 \pm 1.8$ & $5.0 \pm 1.8$ & $5.7 \pm 1.3$ \\
\hline
\end{tabular}

* indicates $p<0.05$ versus $C-S$, \# indicates $p<0.05$ versus $T=60$ within the same experimental group. 
Figure 6.2 Liver wetdry weight ratios $(A)$ and serum actinty of transamases (B) at 2 doys after hemorrhagic shock and resuscitation
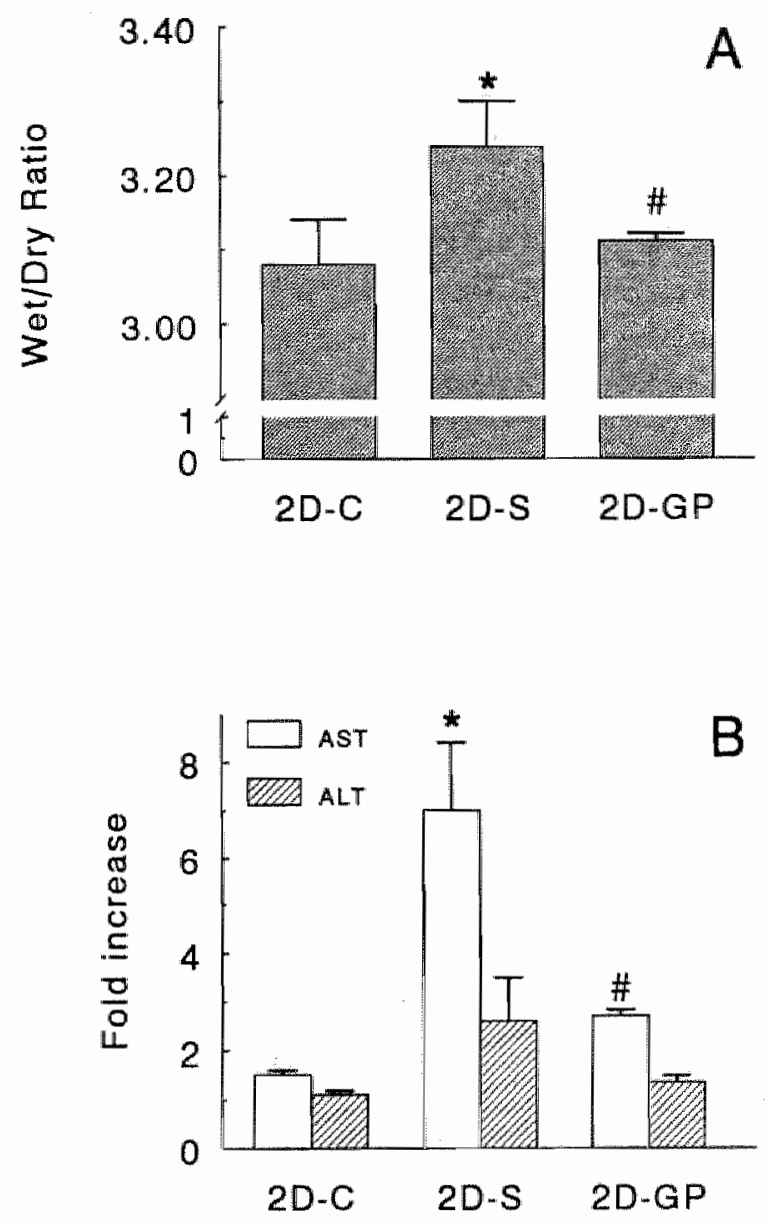

* indicates $p<0.05$ versus $2 \mathrm{D}-\mathrm{C}$, $\#$ indicates $p<0.05$ versus $2 \mathrm{D}-\mathrm{S}$.

The number of leukocytes firmly adhering to the endothelial wall was comparable in both control groups (Figure 6.3), with the highest adhesion numbers in the periportal region (C-S: $394 \pm 16$ leukocytes $/ \mathrm{mm}^{2}$, and C-GP: $352 \pm 27$ leukocytes $/ \mathrm{mm}^{2}$ ). In the non-treated shock group (S-S), firm leukocyte adhesion was significantly enhanced in the periportal $(1032 \pm 95$ leukocytes $/ \mathrm{mm}^{2}$ ) and midzonal $\left(387 \pm 35\right.$ leukocytes $\left./ \mathrm{mm}^{2}\right)$ regions of the liver acinus compared with both control groups. Also, in the pericentral field, the 
number of adhering leukocytes was $311 \pm 77 / \mathrm{mm}^{2}$ in the S-S group, compared with $126 \pm 54 / \mathrm{mm}^{2}$ in the C-S group $(p<0.05)$, and $172 \pm 62 / \mathrm{mm}^{2}$ in the C-GP group $(p>0.05)$. Pretreatment with GP515 markedly attenuated leukocyte adhesion after shock, with a significant reduction in the periportal as well as the midzonal field to $562 \pm 22$ leukocytes $/ \mathrm{mm}^{2}$ and $286 \pm 37$ leukocytes $/ \mathrm{mm}^{2}$, respectively. Moreover, GP515 reduced shock-induced firm leukocyte adhesion in these two fields to a level comparable with saline-treated controls. GP5 15 also reduced shock-induced adhesion in the pericentral region to $224 \pm 89$ leukocytes/ $\mathrm{mm}^{2}$, however without reaching statistical significance compared with saline-treated shock animals.

Figure 6.3 GP5/5 reduces firm leukocyte adhesion in the liver 5 h after hemorrhagic shock and resuscitation as determined by intravital microscopy

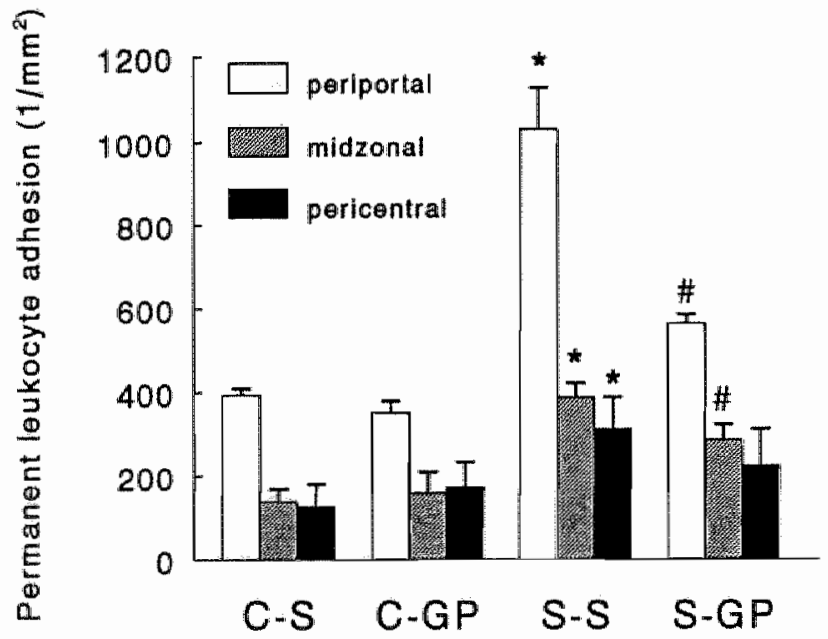

* indicates $p<0.05$ versus C-S, indicates $p<0.05$ versus $S-S$.

\subsubsection{HEPATIC MICROCIRCULATION}

Mean sinusoidal diameter in the saline-treated control group was $11.6 \pm 0.3 \mu \mathrm{m}$, and was non-significantly increased by approximately $7 \%$ in the GP515-treated control group (Figure 6.4A). Following shock and resuscitation, sinusoids were markedly narrowed to a mean diameter of $7.8 \pm 0.2 \mu \mathrm{m}$. In comparison, pretreatment with GP515 partly prevented this sinusoidal narrowing, resulting in a mean sinusoidal diameter of $9.8 \pm 0.1 \mu \mathrm{m}$, a significant increase of 
approximately $26 \%$. In parallel, GP515 tendled to enhance reduced sinusoidal blood flow after shock (Figure 6.4B), almost reaching statistical significance (SS: $37.5 \pm 1.1 \mu \mathrm{l} / \mathrm{sec} v s$. S-GP: $50.8 \pm 3.5 \mu \mathrm{l} / \mathrm{sec}, p=0.06$ ). In control animals however, GP515 did not affect sinusoidal blood flow.

Figure 6.4 GP515 attemuates narrowing of sinusoidal diameters (A) and enhances sinusoidal blood flow (B) 5 h after hemorrhagic shock and resuscitation
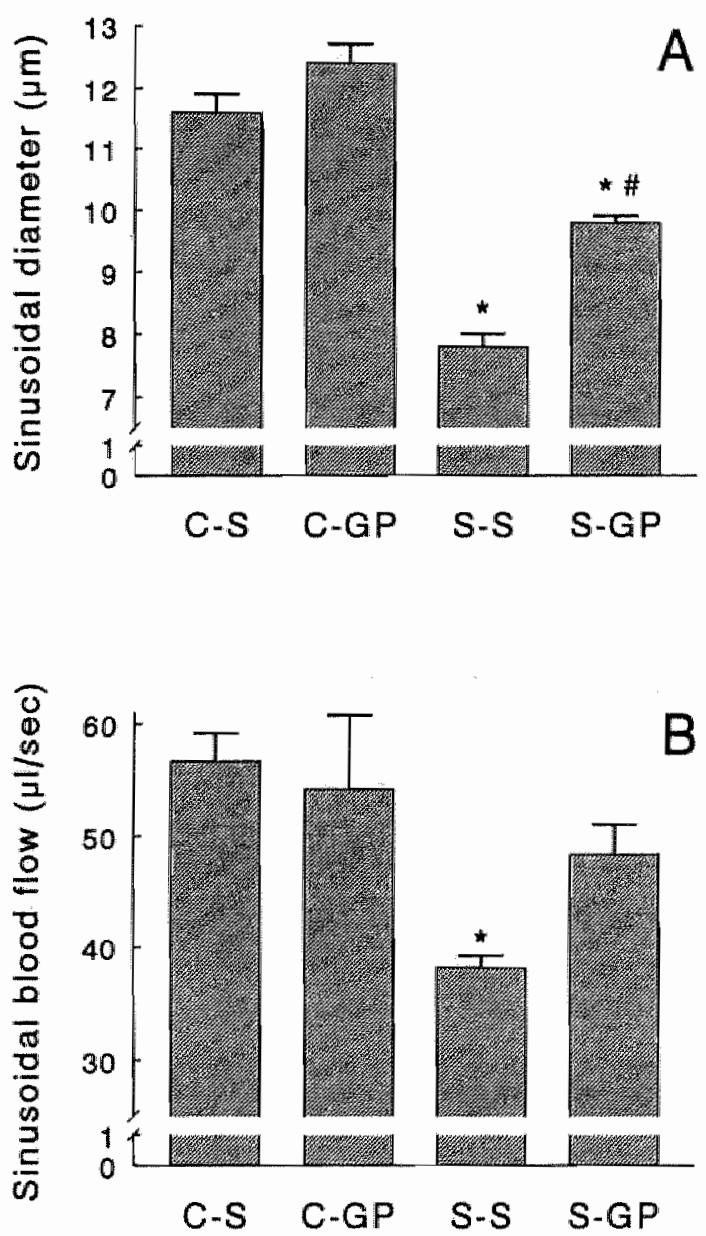

* indicates $p<0.05$ versus $\mathrm{C}-\mathrm{S}$, \# indicates $p<0.05$ versus $\mathrm{S}-\mathrm{S}$. 


\subsection{DiscussIon}

In the present study we have determined the effects of pretreatment with the adenosine kinase inhibitor GP515 on firm leukocyte-endothelial adhesion in the liver after 1 hour of hemorrhagic shock followed by 5 hours of reperfusion. Previous studies using this animal model have revealed two different patterns of leukocyte adhesion in the liver after hemorrhagic shock. First, temporary (shortterm) adhesion is maximally elevated in the first hour of resuscitation, and declines thereafter (21). This type of reversible leukocyte-endothelial interaction may be the correlate of postcapillary leukocyte rolling, and represents an early step in neutrophil recruitment to inflammatory sites. Second, firm (long-term) adhesion, also referred to as leukocyte sticking, increases gradually during the reperfusion period, and is significantly elevated 5 hours after resuscitation from shock (22). Adherence of neutrophils to the vascular endothelium is an important step in neutrophil-mediated injury of endothelial cells, a key pathological event in ischemia reperfusion (3). While initial rolling is considered a prerequisite for firm adherence (24), it is the strong adhesive neutrophil-endothelial interaction that is thought to create a sequestered microenvironment, in which activated neutrophils release proteolytic enzymes and reactive oxygen metabolites that cause the endothelial damage, eventually resulting in increased microvascular permeability and organ edema $(3,25)$.

Therefore, in order to study firm adhesion of leukocytes to the liver sinusoids, we selected the 5-hour reperfusion time frame. Indeed, our present results confirm these earlier observed adhesion patterns, with firm adhesion highly elevated in both shock groups compared with both control groups, and temporary adhesion being identical in all experimental groups. Also, the sublobular adhesion pattern with increasing numbers of firmly adhering leukocytes in the pericentral, midzonal, and periportal regions, respectively, was consistent with previous results in this model (21). Firm leukocyte adhesion to sinusoidal endothelium as observed in this study was previously shown not to be due to mechanical trapping of leukocytes in narrowed sinusoids, but was suggested to be a receptor-specific event (22). The results of the study cited clearly indicate the involvement of adhesion receptors such as ICAM- 1 and the corresponding CD $11 \mathrm{~b} / \mathrm{CD} 18$ complex in the process of firm leukocyte adhesion.

The most prominent finding of this study is that GP515 strongly attenuated shock-induced firm adhesion of leukocytes to the sinusoidal endothelium. As reported by Vedder et al. $(19,20)$ and Mileski et al. $(26)$, inhibition of CD18dependent firm neutrophil adherence effectively reduces neutrophil-mediated 
injury to lungs, liver and the gastrointestinal tract after hemorrhagic shock in rodents as well as in subhuman primates. Similarly, in isolated hepatic ischemia-reperfusion models, it has been established that massive neutrophil infiltration contributes to postischemic liver injury $(18,27)$. While in the aforementioned hemorrhagic shock models gross organ injury was evident after long-term resuscitation, in the present study no gross liver edema, as determined by liver wet/dry ratio"s, was present after 5 h of resuscitation. However, at 2 days after shock, a significant increase in liver wet/dry ratio was observed, which might be due to tissue injury by activated and transmigrated leukocytes. GP515 had protective effects at this timepoint, as indicated by reduced liver wet/dry ratio and significantly reduced serum activity of AST.

The observed anti-adhesive effect of the adenosine-regulating agent GP515 is consistent with reported effects of adenosine and adenosine A2 receptor agonists on neutrophil-endothelial interactions in vitro (10,28-30) and in vivo $(14,15,17,31)$. Although we did not measure in vivo adenosine levels in this study, GP515 has been demonstrated to enhance local endogenous adenosine concentrations in vitro (10), and ex vivo (11) as well as in vivo (16). While activation of neutrophil $A 2$ receptors has been implicated in the anti-adhesive effect of adenosine, currently it has not been established which specific types of leukocyte adhesion molecules are affected by adenosine. Firestein et al. (10) have observed that adenosine interferes with $\mathrm{L}$-selectin-mediated adhesion, and does not affect CD18-dependent adhesion in a static adhesion assay. Others have demonstrated that in vitro integrin-mediated adhesion can also be modulated by adenosine $(32,33)$. Interestingly, adenosine has been shown to inhibit stimulated upregulation of the CD11/CDI8 integrin on human neutrophils in vitro (33). Since GP515 attenuated the firm adhesive leukocyteendothelial interactions, our results would be in support of altered integrinmediated adhesion, although we can not rule out an early effect on selectinmediated rolling. The present results are paralleled by previous similar findings in this same model obtained with the natural glycoprotein neutrophi] inhibitory factor, that inhibits CD11 b/CDI8-mediated adhesion (34).

Adenosine A2 receptors are thought to couple unifocally to adenylate cyclase, with activation resulting in enhanced generation of intracellular cAMP (35). Elevated neutrophil intracullular cAMP has indeed been related to inhibition of $\mathrm{CD} 11 \mathrm{~b} / \mathrm{CD} 18$ surface expression in vitro (32), thus supporting a role for $\mathrm{A} 2$ receptors in down-modulating postischemic integrin-mediated adhesion. In line with this, the CAMP-raising agent pentoxifylline attenuated hemorrhagic shock-induced leukocyte-sinusoidal adhesion in this animal model in an identical fashion as described here for GP515(36). 
Whereas neutrophils have clearly been identified as targets for the antiinflammatory actions of adenosine, endothelial cells have not been ruled out as potential targets for adenosine. On the contrary, adenosine has been shown to inhibit expression of E-selectin and VCAM-1, by activated human endothelial cells in vitro (6). Also, the adenosine analogue 3-deazaadenosine inhibits ICAM-1 biosynthesis in TNF $\alpha$-stimulated cultured human endothelium (37). It remains therefore to be determined whether interference of adenosine with endothelial expression of adhesion molecules is involved in the inhibition of neutrophil-endothelial interactions in vivo.

A second interesting observation in this study is that GP515 displayed a tendency to improve local microcirculation in the liver after resuscitation from shock. Whereas sinusoidal diameters in non-treated shock-animals were significantly reduced compared with sham-operated animals, GP515 significantly enhanced sinusoidal diameters after shock. Although GP515 also slightly enlarged sinusoidal diameters in control animals, it had a relatively stronger effect on sinusoidal diameter after shock. In parallel, while sinusoidal blood flow was significantly reduced after shock, GP515 tended to improve sinusoidal flow after shock, almost reaching statistical significance $(p=0.06)$, but was without effect on blood flow in control animals. While adenosine is known to exert negative chronotropic and dromotropic effects (38), and to cause hypotension (39), GP515 did not affect the cardiovascular parameters MAP, HR and $\mathrm{CO}$ as compared with saline-treated animals in this study. Moreover, systemic hematological parameters were not altered by GP515. Together, these data suggest that GP515 acts to enhance endogenous adenosine at its local site of formation, thereby limiting systemic side effects, and at the same time capitalizing on well-recognized beneficial microcirculatory effects of adenosine during ischemia and reperfusion $(40,41)$.

In summary, using an experimental model that allowed direct visualization of hepatic leukocyte-endothelial interactions and microcirculation, we have demonstrated that systemic administration of the adenosine-regulating agent GP515 has significant anti-adhesive and mild beneficial microcirculatory effects in the early inflammatory response to hemorrhagic shock and resuscitation, which are paralleled by reduced liver injury at the long term. Our results point to the therapeutic potential of GP515 and possibly other adenosine-regulating agents (42-44) in the treatment of ischemia-reperfusion injury. 


\section{REFERENCES}

1. Baue AE. Multiple organ failure, multiple organ dysfunction syndrome, and the systemic inflammatory response syndrome - Where do we stand? Shock 2: 385-397, 1994.

2. Goris RJA, Te Boekhorst TPA, Nuytinck IKS, Grimbrere ISF. Multiple organ failure. Arch Surg 120: 1109-1115, 1985.

3. Welboum CRB, Goldman G, Paterson IS, Valeri CR, Shepro D, Hechtman HB. Pathophysiology of ischaemia-reperfusion injury: central role of the neutrophil. $\mathrm{Br} d$ Surg 78: 651-655, 1991 .

4. Newby AC. Adenosine and the concept of retaliatory metabolites. Trends Biochem Sci 9: 42-44, 1984.

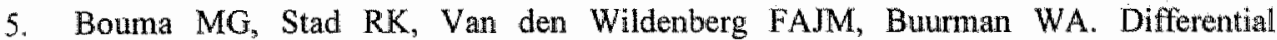
regulatory effects of adenosine on cytokine release by activated human monocytes. $J$ Immunol 153: 4159-4168, 1994.

6. Bouma MG, Van den Wildenberg FAJM, Bumman WA. Adenosine ühibits cytokine release and expression of adhesion molecules by activated human endothelial cells. $A \mathrm{~m} \mathrm{~J}$ Physial 270: C522-C529, 1996.

7. Firestein GS, Boyle D, Bullongh DA, Gruber HE, Sajiadi FG, Montag A, Sambol B, Mullane KM. Protective effect of an adenosine kinase inlnibitor in septic shock. $J$ Immunol 152: 5853-5859, 1994.

8. Parmely MJ, Zhou W-W, Edwards III CK, Borcherding DR, Silverstein R, Morrison DC. Adenosine and a related carbocyclic nucleoside analogue selectively inhibit tumor necrosis factor- $\alpha$ production and protect mice against endotoxin challenge. I Immunol 151: 389-396, 1993.

9. Sajjadi FG, Takabayashi K, Foster AC, Domingo RC, Firestein GS. Inhibition of TNF- $\alpha$ expression by adenosine. Role of A3 adenosine receptors. I Immunol 156: 3435-3442, 1996.

10. Firestein $\mathrm{GS}$, Bullough $\mathrm{DA}$, Erion $\mathrm{MD}$, Jimenez R, Ramirez-Weinhouse $\mathrm{M}$, Barankiewicz J, Smith CW, Gruber HE, Mullane KM. Inhibition of neutrophil adhesion by adenosine and an adenosine kinase inhibitor. The role of selectins. I Immunol 154: $326-334,1995$.

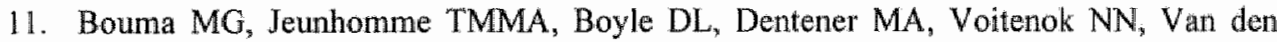
Wildenberg FAJM, Buurman WA. Adenosine inhibits neutrophil degranulation in actiwated human whole blood. Involvement of adenosine A2 and A3 receptors. J Immunol 158: 5400-5408, 1997.

12. Cronstein BN, Levin RI, Belanoff J, Weissmann G, Hirschhorti R. Adenosine: an endogenous inhibitor of neutrophil-mediated injury to endothelial cells. I Clin Invest 78: 760-777, 1986.

13. Cronstein BN, Rosenstern ED, Kramer SB, Weissmann $G$, Hirschhorn R. Adenosine, a physiological modulator of superoxide anion generation by human neutrophils: adenosine acts via an $A_{2}$ receptor on human neutrophils. I Immunol 135: 1366-1371, 1985.

14. Grisham MB, Hernandez LA, Granger DN. Adenosine inhibits ischernia-reperfusioninduced leukocyte adherence and extravasation. Am J Physiol 257: H1334-H1339, 1989. 
15. Wolte D, Lorenzen A, Lehr H-A. Zimmer F-J, Klotz K-N, and Messmer K. Reduction of postischemic leukocyte-endothelium interaction by adenosine via $\mathrm{A}_{2}$ receptor. NannySchmiedeberg's Arch Pharnacol 346:234-237, 1992.

16. Cronstein BN. Naine D, Firestem GS. The antinftammatory effects of an adenosine kinase inhibitor are mediated by adenosme. Arthritis Rhewn 38: 1040-1045, 1995.

17. Rosengyen $\mathrm{S}$. Bong $\mathrm{GW}$, Firestein $\mathrm{CS}$. Anti-inflammatory effects of an adenosine kinase inhibitor. Decreased neutrophil accumulation and vascular leakage. I Immunol 154 : $5444-5451,1995$.

18. Jaeschke H, Farhood A, Smith CW. Neutrophils contribute to ischemia/reperfusion injury in rat liver in vivo. FASEB $J 4: 3355-3359,1990$.

19. Vedder NB, Winn RK, Rice CL, Chi EY, Arfors K-E, Harlan JM. A monoclonal antibody to the adherence-promoting leukocyte glycoprotein, CDI8, reduces organ injury and improves survival from hemormagic shock and resuscitation in rabbits. $J \mathrm{C} / \mathrm{m}$ Invest 81: 939-944, 1988.

20. Vedder NB, Fouty BW, Winn RK, Harlan JM, Rice CL. Role of neutrophils in generalized reperfusion injury associated with resuscitation from shock. Surgery 106: $509-516,1989$.

21. Marzi 1, Bauer C, Hower R, Bühren V. Leukocytemendothelial interactions in the liver after hemorrhagic shock in the rat. Circ Shock 40: 105-114, 1993.

22. Bauen C, Marzi I, Bauer M. Fellger $H$, Larsen $R$. Interleukin-1 receptor antagonist attenuates leukocyte-endothelial interactions in the liver after hemorhagic shock in the rat. Crit Care Med 23: 1099-1105, 1995.

23. Rappaport AM. Acinar units and the pathophysiology of the liver. In: Rouilter C (Ed.), The Liver. Morphology, biochemisty, physiology, Vol. 1. Academic, London, pp. 265 $328,1963$.

24. Granger DN, Kubes $P$. The microcirculation and inflammation: modulation of leukocyte-endothelial cell adhesion. J Leukoc Biol 55: 662-675, 1994.

25. Weiss SJ. Tissue destruction by neutrophils. New Eng J Med 320: 365-376, 1989.

26. Mileski WJ, Winn RK, Vedder NB, Pohlman TH, Harlan JM, Rice CL. Inhibition of CD\|8-dependent neutrophil adherence reduces organ injury after hemorthagic shock in primates. Sugery 108: 206-212, 1990.

27. Suzuki S, Toledo-Pereyra LH, Rodriguez FJ, Cejalvo D. Nentrophil infiltration as an important factor in liver ischemia and reperfusion injury. Transplantation 55: 1265 1272.1993.

28. Bullough DA, Magill MJ, Firestein GS, Mullane KM. Adenosine activates $\mathrm{A}_{2}$ receptors. to inhibit neutrophil adhesion and injury to isolated cardiac myocytes. I Immunol 155: 2579-2586, 1995 .

29. Cronstein BN, Levin RI, Philips $M$, Hirschhorn $R$, Abramson SB, Weissman $G$. Neutrophil adherence to endothelium is enhanced via adenosine Al receptors and inhibited via adenosine A2 receptors. J Immwnol 148: 2201-2206, 1992.

30. Felsch A, Stöcker K, Bonchard U. Phorbol ester-stimulated adherence of neutrophils to endothelial cells is reduced by adenosine $A_{2}$ receptor agonists. J Immunol $155: 333-338$, 1995.

31. Asako $H$, Wolf $R E$, Granger DN. Leukocyte adherence in rat mesenteric venules: effects of adenosine and methotrexate. Gastraenterology 104:31-37, 1993. 
32. Derian CK, Santulli R, Rao PE, Solomon HF, Barrett JA. Inhibition of chemotactic peptide-induced neutrophil adhesion to vascular endothelium by CAMP modulators. I Immunol 154: 308-317, 1995.

33. Wollner A, Wollner $S$, Smith JB. Acting via A2 receptors, adenosine inhibits the upregulation of Mac-1 (CD1 $1 \mathrm{~b} / \mathrm{CD} 18)$ expression on FMLP-stimulated neutrophils. Am J Respir Cell Mol Biol 9: 179-185, 1993.

34. Bauer C, Siaplaouras S. Soule H, Moyle M, Marzi I. A natural glycoprotein (NIF) inhibiting $\mathrm{CD} 1 \mathrm{~b} / \mathrm{CD} 18$ reduces leukocyte adhesion in the liver following hemotrhagic shock. Shock 4: 187-192, 1995.

35. Stiles G. Adenosine receptors. J Biol Chem 267: 6451-6454, 1992.

36. Marzi I, Maier M, Herzog C, Bauer M. Influence of pentoxifylline and albifylline on liver microcirculation and leukocyte adhesion after hemorrhagic shock in the rat. $J$ Trauma 40: 90-96, 1996.

37. Jurgensen $\mathrm{CH}$, Huber BE, Zimmerman TP, Wolberg G. 3-Deazaadenosine inhibits leukocyte adhesion and ICAM-1 biosynthesis in tumor necrosis factor-stimulated human endothelial cells. I Immunol 144: 653-661, 1990.

38. Fredholm BB, Sollevi A. Cardiovascular effects of adenosine. Clin Physiol 6: 1-21, 1986.

39. Belardinelli L, Linden J, Berne RM. The cardiac effects of adenosine. Prog Cardiovasc Dis 32: 73-97, 1989.

40. Engler R. Consequences of activation and adenosine-mediated inhibition of granulocytes during myocardial ischemia. Federation Proc 46: 2407-2412, 1987.

41. Forman MB, Velasco CE, Jackson EK. Adenosine attenuates reperfusion injury following regional myocardial ischaemia. Cardiovase Res 27: 9-17, 1993.

42. Fabian TC, Fabian MJ, Yockey JM, Proctor KG. Acadesine and lipopolysaccharideevoked pulmonary dysfunction after resuscitation from traumatic shock. Surgery 119 : 302-315, 1996.

43. Mullane $K$, Bullough $D$, Shapiro $D$. From academic vision to clinical reality. A case study of acadesine. Trends Cardiovasc Med 3: 227-234, 1993.

44. Spiers JP, Fabian TC, Kudsk KA, Proctor KG. Resuscitation of hemorrhagic shock with hypertonic saline/dextran or lactated Ringer's supplemented with AlCA riboside. Circ Shock 40: 29-36, 1993. 

Chapter 7

\section{General Discussion}

Part of this chapter has been published as:

Bouma MG, Van den Wildenberg FAJM, Buurman WA

The anti-inflammatory potential of adenosine in ischemia-reperfusion injury: established and putative beneficial actions of a retaliatory metabolite Shock 8(5): 313-320, 1997 


\subsection{A NEW DIMENSION TO THE RETALIATORY METABOLITE CONCEPT?}

As mentioned in Chapter 1 , adenosine has been termed a retaliatory metabolite in the setting of ischemia-reperfusion, mainly by virtue of its favorable metabolic and cardiovascular actions (Table 7.1). In addition, its welldocumented specific inhibitory effects on neutrophil superoxide anion generation in vitro have been assumed to underlie its anti-inflammatory, cytoprotective role in reperfusion injury.

In this thesis, we have presented results from several in vitro studies, describing novel anti-inflammatory actions of adenosine on different immunocompetent cell types, which are known to be involved in the inflammatory response to ischemia-reperfusion, as well as in other inflammatory conditions. In addition, new data have recently emerged from experimental studies by others, that have considerably broadened the scope of adenosine's anti-inflammatory actions (Table 7.1). Although most of these new findings originate from in vitro studies, and have thus far not all been confirmed in in vivo ischemia-reperfusion, in our view they may have potential relevance to this pathological entity, and are therefore discussed here. Together, the data presented in this thesis suggest that the endogenous metabolite adenosine may be effective at the effector, the mediator, as well as the tissue level of reperfusion injury (Figure 7.1). Moreover, some of these newly recognized antiinflammatory features of adenosine have indeed been proven effective in other inflammatory conditions, such as sepsis, where disturbances in organ microcirculation and tissue hypoxia appear to play an important role as well.

\subsubsection{ANTII-INFLAMMATORY ACTIONS AT THE EFFECTOR LEVEL}

In Chapter 2 we have reported that adenosine inhibits ex vivo release of neutrophil granule constituents in human whole blood stimulated with either LPS or TNF $\alpha$, and that this inhibition occurs through involvement of both A2 and $\mathrm{A} 3$ adenosine receptors. A modulatory effect of adenosine on neutrophil degranulation had been suggested previously in few in vitro studies using isolated neutrophil suspensions $(1,2)$, but had thus far remained controversial (3-5). Particularly the inhibition of elastase release by adenosine could provide a possible target for therapeutic intervention in inflammatory conditions that are characterized by neutrophil-mediated proteolytic tissue injury. In this respect, it is of significance that Inauen et al. (6) have emphasized the importance of neutrophill elastase in hypoxia-reoxygenation-induced endothelial cell injury. Moreover, there is progressive and compelling evidence that the contribution of 
elastase and other neutrophil proteases to postischemic injury in wivo may be as prominent as the oxidant injury (7-12), and that neutrophil proteolytic enzymes act in synergism with OFR to produce reperfusion injury (13). Therefore, besides its well-characterized effects on neutrophil oxidative burst, adenosine might also contribute considerably to limitation of microvascular reperfusion injury by inhibiting neutrophil degranulation.

Figure 7.1 Schematic diagram of the established and putative actions of adenosine on neutrophil chemotaxis and activation, and subsequent endothelial adherence and iransendothelial emigration in ischemia-reperfusion

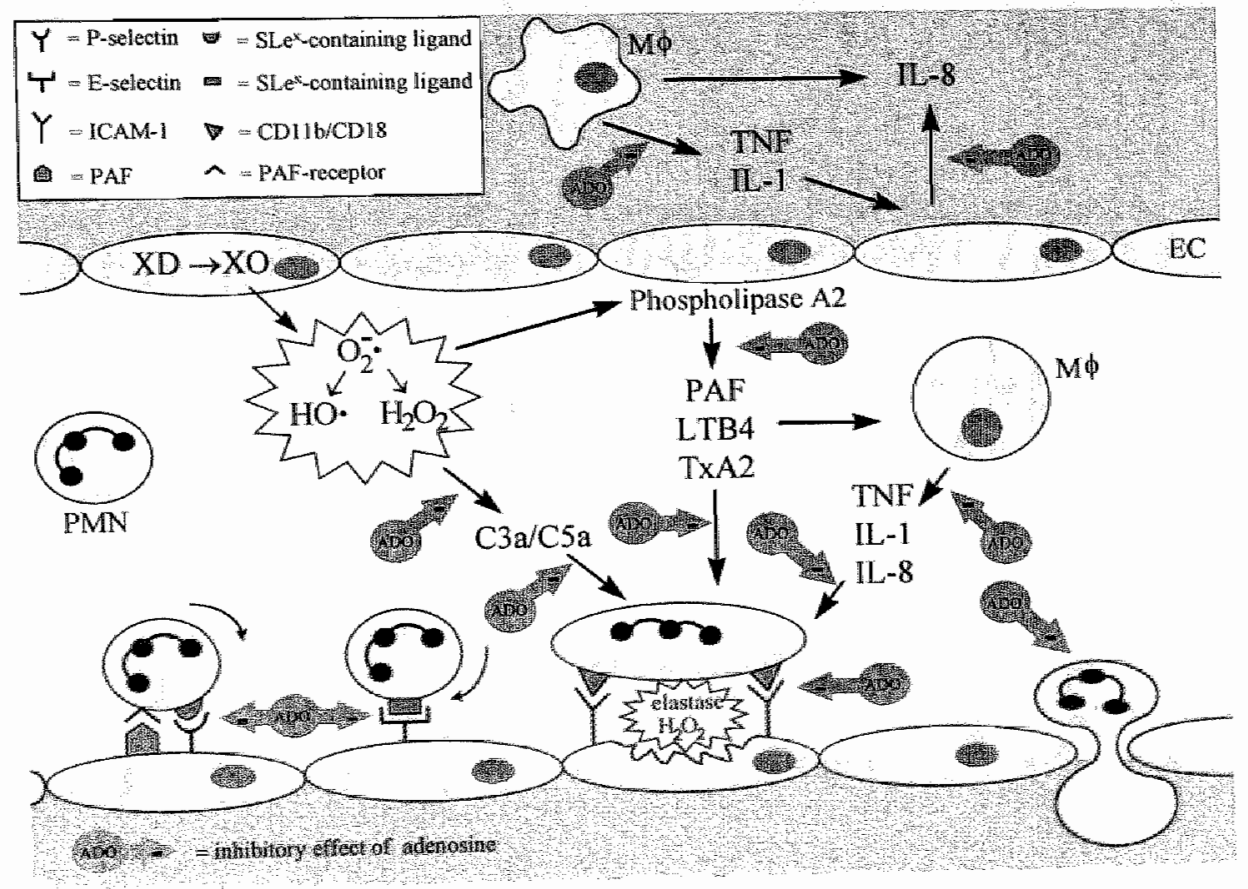

$\mathrm{EC}=$ endothenial cell; $\mathrm{M} \Phi=$ macrophage/monocyte; $S L \mathrm{e}^{\mathrm{x}}=$ sialyl-Lewis $\mathrm{X}$ tetrasaccharide: $\mathrm{XD}=$ xanthine dehydrogenase; $\mathrm{XO}=\mathrm{xanthine}$ oxidase. For other abbreviations, see text and List of Abbreviations. 
Activation of cellular anti-oxidant defense systems has recently been proposed as a novel mechanism whereby adenosine may provide protection against OFRmediated reperfusion injury $(14,15)$. In these studies, evidence was presented that endogenous adenosine increases the activity of the anti-oxidant enzymes superoxide dismutase, catalase, and glutathione peroxidase in a variety of cell types, including rat basophillic leukocytes and human endothelial cells. These effects were found to be dependent on $\mathrm{A} 3$ receptor activation and were accompanied by a decrease in the degree of lipid peroxidation in these cells. Thus, complementary to inhibition of oxidant production, stimulation of antioxidant activity by adenosine also seems to be involved in its cytoprotective effect. In view of this, the results described in Chapter 5, where pharmacological interference in adenosine metabolism potently enhanced adenosine release from endothelial cells subjected to hypoxia, could be of interest.

Table 7.1 Established and putative beneficial effects of adenosine in ischemia-reperfusion.

References

\begin{tabular}{|c|c|}
\hline $\begin{array}{l}\text { Metabolic effects } \\
\text { purine salvaging } \\
\text { inhibition of lipolysis } \\
\text { enhancement of glucose transport } \\
\text { stimulation of gluconeogenesis }\end{array}$ & \\
\hline $\begin{array}{l}\text { Cardiovascular effects } \\
\text { vasodilation } \\
\text { inhibition of platelet aggregation } \\
\text { inhibition of vasoconstrictive mediators } \\
\text { negative inotropy and dromotropy } \\
\text { preconditioning }\end{array}$ & \\
\hline $\begin{array}{l}\text { Anti-inflammatory effects } \\
\text { inhibition of neutrophil superoxide } \\
\text { inhibition of neutrophil degranulation } \\
\text { activation of anti-oxidants } \\
\text { inhibition of cytokines } \\
\text { inhibition of eicosanoids } \\
\text { inhibition of complement } \\
\text { inhibition of adhesion molecule expression or adhesion }\end{array}$ & $\begin{array}{l}1,2, \text { Chapter } 2 \\
14,15 \\
18-22, \text { Chapters } 3 \text { and } 4 \\
25,26 \\
27 \\
29-32, \text { Chapters } 4 \text { and } 6\end{array}$ \\
\hline
\end{tabular}




\subsubsection{ANTI-INFLAMMATORY ACTIONS AT THE MEDIATOR LEVEL}

In Chapter 3 we have described the potent inhibitory actions of adenosine on the release of the pro-inflammatory cytokines TNF $\alpha, I L-6$ and IL- 8 by LPS- or IL-I $\beta$-stimulated human monocytes. Moreover, in Chapter 4 we demonstrate that adenosine also negatively affects release of IL- 6 and IL- 8 by activated cultured human endothelial cells. Recently, several other groups have independently presented evidence that adenosine can reduce cytokine release. Specifically, release of TNF $\alpha$ by activated human monocytes $(16,17)$ and macrophages of human (18) as well as rodent origin (19-21) is potently attenuated by adenosine. While we and others have demonstrated the participation of A2 receptors in adenosine-mediated inhibition of TNF $\alpha(17,18$, 21 ), recently a major role for $A 3$ receptors has been implicated in this event (18). Given the involvement of TNF $\alpha$ as a proximal mediator in the pathogenesis of sepsis and ischemia-reperfusion, this anti-inflammatory feature of adenosine may prove to be useful in the treatment of these conditions. Indeed, adenosine and adenosine-regulating agents reduce systemic levels of TNF $\alpha$ and protect from mortality in various murine models of septic shock (19, 20). Moreover, we have shown that adenosine is also capable of attenuating release of other pro-inflammatory cytokines, such as IL- 6 and IL- 8 by cultured human monocytes as well as endothelial cells. Likewise, its structural analogue 3-deazaadenosine has been demonstrated to inhibit the production and biological activity of IL-1 derived from human monocytes in vitro (22), but a similar inhibitory effect of adenosine itself on IL-1 release in vivo could thus far not be confirmed $(19,20)$. In addition to its inhibitory actions on the production of pro-inflammatory cytokines, adenosine has recently been shown by LeMoine et al. (23) to enhance the secretion of the anti-inflammatory cytokine IL-10.

Interestingly, they suggested that this phenomenon participates in adenosinemediated inhibition of TNF $\alpha$, which, in addition to the known inhibitory effects of $1 \mathrm{~L}-10$ on OFR production (24), could be of significance in the setting of ischemia-reperfusion. Furthermore, adenosine has recently been found to inhibit synthesis of predominantly neutrophil-derived $\mathrm{LTB}_{4}$ in TNF $\alpha$ and LPSactivated human whole blood ex vivo via engagement of A2 receptors (25), which could have specific significance with regard to sepsis as well as ischemia-reperfusion. Likewise, release of $\mathrm{TxA}_{2}$ can be inhibited by adenosine in in vivo coronary ischemia and reperfusion (26). Adenosine may also interfere with activation of the classical complement cascade, as it has been demonstrated to inhibit the production of the second complement component $\left(\mathrm{C}_{2}\right)$ by binding to $\mathrm{A} 2$ receptors on human monocytes $(27)$. 


\subsubsection{ANTI-INFLAMMATORY ACTIONS AT THE TISSUE LEVEL.}

While the anti-adhesive actions of adenosine have been attributed to its effects on neutrophil expression of integrins and selectins, endothelial cells have not been ruled out as potential targets for the anti-adhesive actions of adenosine. On the contrary, in Chapter 4 we have presented evidence that adenosine is capable of inhibiting de novo expression of E-selectin and VCAM- 1 by cultured human endothelial cells. Although we could not demonstrate an inhibitory effect on upregulated expression of ICAM-1, others (28) have demonstrated that the structural adenosine analogue 3 -deazaadenosine inhibits TNF $\alpha$-induced ICAM1 upregulation by HUVEC. In Chapter 6 we have presented data indicating that endogenous adenosine attenuates firm leukocyte-endothelial adhesion in liver sinusoids after hemorrhagic shock and resuscitation, suggesting an inhibitory effect on integrin-mediated adhesion. Similarly, interference of adenosine with integrin-mediated leukocyte-endothelial interactions has been suggested in other experimental in vivo ischemia-reperfusion models (29-31). Others have demonstrated an inhibitory effect of adenosine on selectin-mediated adhesion (32). However, actual downregulation of endothelial expression of adhesion molecules by adenosine or its analogues in vivo has thus far not been demonstrated, and the potential relevance of these in vitro findings to inhibition of ischemia-reperfusion-induced leukocyte-endothelial adhesion remains therefore to be determined.

\subsection{THERAPEUTIC IMPLICATIONS}

As described above, adenosine exerts metabolic, cardiovascular, and antiinflammatory activities that may provide protection against reperfusion injury (summarized in Table 7.1), and, consequently, this has raised the possibility of therapeutic intervention to take advantage of its established and putative beneficial effects. However, the therapeutic use of adenosine is limited by its severe cardiovascular side effects, as well as its very short halflife in the systemic circulation. As stated earlier, adenosine acts on cells in an autocrine and paracrine manner. Therefore, as an alternative therapeutic strategy, different pharmacological agents have been developed that increase endogenous adenosine concentrations at its local site of formation, thereby enhancing its protective actions confined to its target site, and at the same time minimizing systemic side effects. As demonstrated in Figure 7.2 and summarized in Table 7.2 , there are several potential approaches to implement this strategy. While 
some of these pharmacological approaches have indeed been proven successful in limiting ischemia-reperfusion injury in vivo, both in animal models as well as clinically, others have been focusing mainly on the diverse anti-inflammatory effects of adenosine, and have been successfully applied in acute inflammatory conditions other than ischemia-reperfusion, such as septic shock and skin models of inflammation.

Figure 7.2 Intracellular metabolism of adenosine and potential targets for phamacological interventions

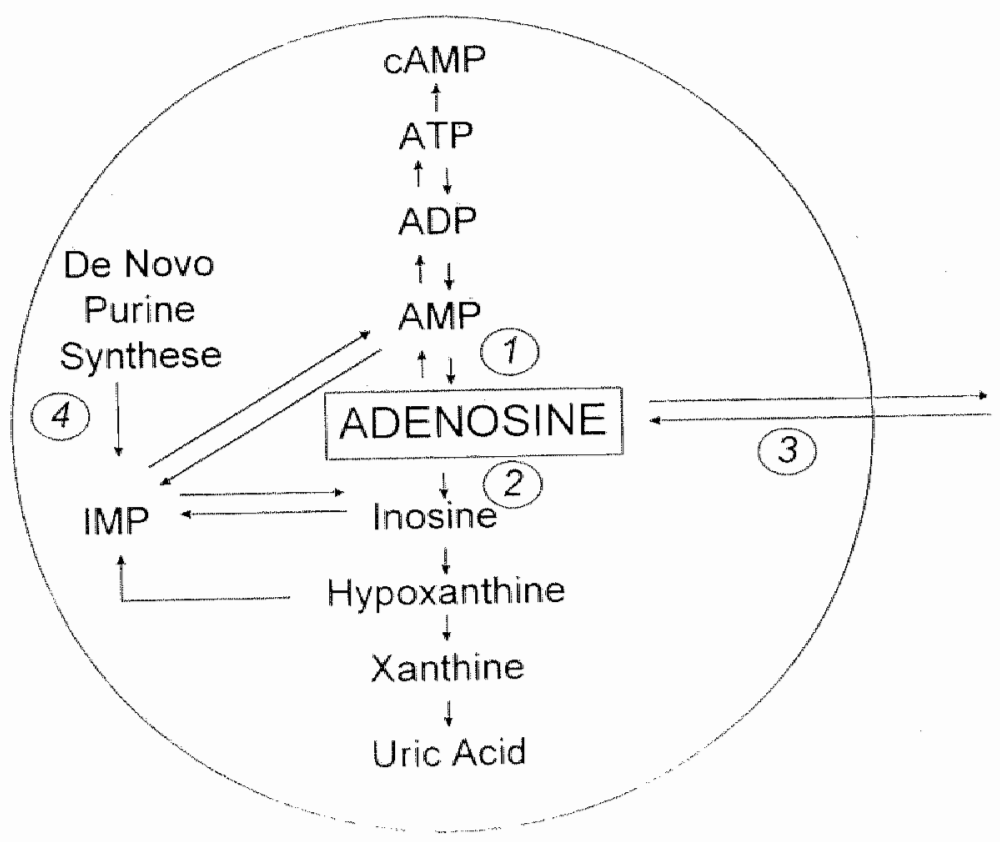

$1=$ adenosine kinase, $2=$ adenosine deaminase, $3=$ nucleoside transport, $4=\mathrm{AlCAR}$ transformylase. 
Table 7.2 Potential therapeutic pharmacological interventions in adenosine metabolism in ischemia-reperfusion and other inflammatory disorders

References

Adenosine kinase inhibitors

Adenosine deaminase inhibitors

Nucleoside transport inhibitors

Acadesine
$19,32-35$, Chapters 2,5 and 6

$35,38-45,49$, Chapters 3 and 4

$2,35,39,41,46,48,49,51,70$

$52,54-66$

\subsubsection{ADENOSINE KINASE INHIBITION}

In this thesis, we have used the adenosine kinase inhibitor GP515 in several studies to support the significance of endogenous adenosine in the observed inhibitory effects on inflammatory cell function. In Chapter 2 it was demonstrated that GP515 significantly enhances endogenous adenosine levels in whole blood ex vivo, thereby attenuating neutrophil degranulation. Likewise, potentiating effects of GP515 on endothelial adenosine release were reported in Chapter 5 . These findings are supported by previous studies demonstrating that inhibition of adenosine kinase by GP515 or other adenosine kinase inhibitors enhances endogenous extracellular adenosine concentrations (32-35). In these studies GP515 reduced selectin-mediated neutrophil adhesion in vitro (32), as well as neutrophil emigration and vascular leakage in carrageenan-induced inflammation in vivo $(33,34)$. The observation that GP515 enhances endothelial adenosine release, particularly during hypoxic conditions as was demonstrated in Chapter 5, leads us to hypothesize that pharmacological interference in endothelial adenosine metabolism may be relevant to the treatment of reperfusion injury. In support of this hypothesis, it is of interest that adenosine released from endothelial cells has indeed been demonstrated to inhibit neutrophil activation and subsequent endothelial injury $(36,37)$. Moreover, consistent with the reported effects of adenosine in vitro, GP515 was recently shown to reduce systemic release of TNF $\alpha$ and pulmonary neutrophil accumulation, and concomitant mortality, in different animal models of septic shock (19). In Chapter 6 we have also demonstrated its efficacy in the setting of ischemia-reperfusion, by potently attenuating hemorrhagic shock and resuscitation-induced leukocyte-endothelial adhesion and sinusoidal narrowing in the rat liver, and reducing liver injury. 


\subsubsection{ADENOSINE DEAMINASE INHIBITION}

Pharmacological inhibition of adenosine deaminase, to enhance endogenous adenosine levels, has been applied mainly in the setting of myocardial and cerebral ischemia and reperfusion $(35,38,39)$. The adenosine-mediated cardioprotective and neuroprotective actions of adenosine deaminase inhibitors include enhanced recovery of high-energy phosphates (40-42), improved blood flow $(35,40)$, and scavenging of $\operatorname{OFR}(43,44)$. Analogous to the inhibitory effects of the adenosine kinase inhibitor GP515 on neutrophil degranulation in vitro, as described in Chapter 2, we have demonstrated that adenosine deaminase inhibition by EHNA or deoxycoformycin reduces release of TNF $\alpha$ by monocytes (Chapter 3), and expression of adhesion molecules by endothelial cells in vitro (Chapter 4), presumably by enhancing endogenous levels of adenosine. Similarly, Eigler et al. (45) have recently emphasized the significance of endogenous adenosine in inhibition of monocyte-derived TNF $\alpha$ production.

\subsubsection{NUCLEOSIDE TRANSPORT INHIBITION}

The rationale for the use of nucleoside transport inhibitors is to prevent the washout of adenosine from the ischemic interstitial space to the vascular lumen upon reperfusion, thus prolonging the accumulation of adenosine in the ischemic and reperfused area (46). Specifically in the myocardium, where the nucleoside transport protein has been localized mainly in the endothelium lining the coronary vessels, inhibition of the functional transporter prevents degradation of adenosine within the endothelial cell by adenosine deaminase, and delays subsequent clearance into the circulation (46). The presence of an endothelial nucleoside transporter has also been demonstrated in microvessels of the brain and other organs (47). Hence, nucleoside transport inhibitors have been proven protective from reperfusion injury in the heart $(39,48,49)$, and brain $(41,50)$. Recently, a protective effect of nucleoside transport blockade on post-transplant renal function and survival was demonstrated in a canine model of kidney autotransplantation (51).

\subsubsection{ACADESINE}

The purine nucleoside analogue acadesine (AlCA riboside (=AICAR), 5-amino1-B-D-ribofuranosyl-imidazole-4-carboxamide) has been termed the prototype adenosine-regulating agent for reducing myocardial ischemic injury $(52,53)$. 
After cellular uptake, it enters the de novo purine biosynthetic pathway by phosphorylation to AlCA-ribotide (ZMP), and is subsequently further metabolized to inosine monophosphate (IMP). The combined weak inhibitory effects of acadesine on adenosine deaminase and adenosine kinase, and of ZMP on enzymes that are reciprocally involved in IMP-AMP conversion (Figure 7.2), are thought to account for the adenosine-enhancing activity of acadesine $(52,53)$. Its functional benefits have been extensively studied in various models of myocardial ischemia and reperfusion, and may include many of the cardiovascular, metabolic and anti-inflammatory effects described above (5458). While the protective effects of acadesine have yet been evaluated in human myocardial ischemia, its beneficial potential has also been demonstrated in animal models of intestinal ischemia-reperfusion (59) and hemorrhagic shock and resuscitation $(60,61)$. Moreover, the potential relevance of AICAR to treatment of inflammatory conditions other than ischemia-reperfusion has recently become evident, as it was established that the anti-inflammatory mechanism of methotrexate and sulfasalazine, two antiphlogistic agents widely used in the treatment of rheumatoid arthritis and inflammatory bowel diseases, is in fact due to their capacity to induce accumulation of AICAR with subsequent increased adenosine release at inflamed sites (62-66).

\subsection{CONCLUSION AND PERSPECTIVES}

In this thesis we have depicted the anti-inflammatory potential of adenosine. The concept of adenosine as an immunoregulatory agent, as originally introduced by Cronstein, was elaborated further by demonstrating the suppressive actions of adenosine on several cell types of human origin, that are involved in inflammatory reactions. While we have applied adenosine agonists and antagonists to investigate the effects of adenosine in the experimental studies described in this thesis, we have also provided evidence for a role of endogenous adenosine using adenosine-regulating agents that augment endogenous adenosine levels. Based on our findings, we propose that while under physiological conditions adenosine seems to be an important mediator of metabolic, cardiovascular, and immunological homeostasis, it could provide a "natural defense system" against severe metabolic and inflammatory insults. Particularly in ischemia-reperfusion, where its formation is directly linked to ATP catabolism, adenosine could provide protective effects at multiple levels in the pathogenesis of this condition. Therefore, pharmacological enhancement of this endogenous, multifactorial defense mechanism by agents that promote 
adenosine release at its site of formation may have potential therapeutio relevance to protect from ischemia-reperfusion injury. Some of these adenosineregulating agents, such as acadesine and nucleoside transport inhibitors, have already proven their therapeutic efficacy in the clinical setting, whereas others are still in an experimental or preclinical stage, but seem to hold therapeutic promise. Given the broad anti-inflammatory potential of adenosine, pharmacological interference in endogenous adenosine metabolism could form an attractive alternative strategy for the therapeutic approaches outlined in Chapter 1 , since it may be effective at multiple inflammatory levels, and is not accompanied by the autoimmune phenomena associated with monoclonal or polyclonal antibody therapy $(67,68)$. Moreover, by capitalizing on the antiinflammatory actions of endogenous adenosine, adenosine-regulating agents may also proof to be useful in the treatment of other inflammatory conditions, including sepsis, inflammatory bowel diseases, and rheumatoid arthritis.

\section{ACKNOWLEDGEMENT}

The authors thank Mart-Jan Rongen M.D., and Anita Vreugdenhil for their help in preparing the illustrations.

\section{REFERENCES}

1. Schrier DJ, Imre KM. The effects of adenosine agonists on human neutrophil function. $J$ Immunol 137: 3284-3289, 1986.

2. Zhang Y, Fredholm BB. Propentofylline enhancement of the actions of adenosine on neutrophil leukocytes. Biochem Pharmacol 48: 2025-2032, 1994.

3. Cronstein BN, Kramer SB, Weissmann G, Hirschhorn R. Adenosine: a physiological modulator of superoxide anion generation by human neutrophils. J Exp Med 158: 11601.177, 1983.

4. Cronstein BN, Kramer SB, Rosenstein ED, Korchak HM, Weissmann, Hirschhorn R. Occupancy of adenosine receptors raises cyclic AMP alone and in synergy with occupancy of chemoattractant receptors and inhibits membrane depolarization. Biochem J252: 709-715, 1988.

5. McGarrity ST, Stephenson AH, Webster RO. Regulation of human neutrophil functions by adenine nucleotides. J Imminol 142: 1986-1994, 1986.

6. Inauen W, Granger DN, Meininger CJ, Schelling ME, Granger HJ, Kvietys PR. Anoxiareoxygenation-induced, neutrophil-mediated endothelial cell injury: role of elastase. Am $J$ Physiol 259: H925-H931, 1990.

7. Carden DL, Korthuis RJ. Protease inhibition attenuates microvascular dysfunction in postischemic skeletal muscle. Am J Physiol 271: H1947-H1952, 1996. 
8. Zimmerman BJ, Granger DN. Reperfusion-induced leukocyte infiltration: role of elastase. Am of Physiol 259: H390-H394, 1990.

9. Binns OAR, Delima NF, Buchanan SA, Mauney MC, Cope JT, Thies SD, Shockey KS, Tribble $\mathrm{CG}_{\text {, }}$ Kron $\mathbb{I L}$. Neutrophil endopeptidase inhibitor improves pulmonary function during reperfusion after eighteen-hour preservation. I Thorac Cardiovasc Surg 112: 607$613,1996$.

10. Crinnion JN, Homer-Vanniasinkam S, Hatton R. Parkin SM, Gough MJ. Role of neutrophil depletion and elastase inhibition in modifying skeletal muscle reperfusion injury. Cardiovasc Surg 2: 749-753, 1994.

11. Yamaguchi $\mathrm{Y}$, Akizuki $\mathrm{E}$, Ichiguchi $\mathrm{O}$, Matsumura $\mathrm{F}$, Goto $\mathrm{M}$, Miyanari $\mathrm{N}$, Mori $\mathrm{K}$, Yamada S, Ogawa M. Neutrophil elastase inhibitor reduces neutrophil chemoattractant production after ischemia-reperfusion in rat liver. Gastroenterology 112:551-560, 1997.

12. Tomizawa $N$, Ohwada $S$, Ohya $T$, Takahashi $T$, Ichikawa H, Kobayashi J, Kamoshita N, lino $Y$, Morishita $Y$. Effects of neutrophil elastase inhibitor on reperfusion injury in the canine liver. Transpi Proc 28: 1767-1768, 1996.

13. Welboum CRB, Goldman G, Paterson IS, Valeri CR, Shepro D, Hechtman HB. Neutrophil elastase and oxygen radicals: synergism in lung injury after hindlimb ischemia. Am J Physiol 260: H1852-H1856, 1991.

14. Maggirwar SB, Dhanraj DN, Somani SM, Ramkumar V. Adenosine acts as an endogenous activator of the cellular antioxidant defense system. Biochem Biophys Res Comm 201: 508-515, 1994.

15. Ramkumar V, Nie Z, Rybak LP, Maggirwar SB. Adenosine, antioxidant enzymes and cytoprotection. Trends Pharmacol Sci 16: 283-285, 1995.

16. Bouma MG, Stad RK, Van den Wildenberg FAJM, Buurman WA. Differential regulatory effects of adenosine on cytokine release by activated human monocytes. $J$ Immunol 153: 4159-4168, 1994.

17. Lee HT, Schroeder CA, Shah PM, Babu SC, Thompson CI, Belloni FL. Preconditioning with ischemia or adenosine protects skeletal muscle from ischemic tissue reperfusion injury. J Surg Res 63: 29-34, 1996.

18. Sajjacli FG, Takabayashi K, Foster AC, Domingo RC, Firestein GS. Inhibition of TNF- $\alpha$ expression by adenosine. Role of A3 adenosine receptors. I Immunol 156: 3435-3442, 1996.

19. Firestein GS, Boyle D, Bullough DA, Gruber HE, Sajjadi FG, Montag A, Sambol B, Mullane KM. Protective effect of an adenosine kinase inhibitor in septic shock. I limmunol 152:5853-5859, 1994.

20. Parmely MJ, Zhou W-W, Edwards III CK, Borcherding DR, Silverstein R, Morrison DC. Adenosine and a related carbocyclic nucleoside analogue selectively inhibit tumor necrosis factor- $\alpha$ production and protect mice against endotoxin challenge. $J$ immunol $151: 389-396,1993$.

21. Prabhakar U, Brooks DP, Lipshlitz D, Esser KM. Inhibition of LPS-induced TNFa production in human monocytes by adenosine $\left(\mathrm{A}_{2}\right)$ receptor se']ective agonists. Int $I$ Immunopharmacol 17: 221-224, 1995.

22. Schmidt JA, Bomford R, Gao X-M, Rhodes J. 3-Deazaadenosine: an inhibitor of interleukin 1 production by human peripheral blood monocytes. Int J Immunopharmacol 12: $89-97,1990$. 
23. Le Moine $\mathrm{O}$, Stordeur $\mathrm{P}$, Schandené L, Marchant A, De Groote D. Goldman M, Devière J. Adenosine enhances $\mathrm{LL}-10$ secretion by human monocytes. I Immunol 156: 4408$4414,1996$.

24. Bogdan C, Vodovotz $Y$, Nathan C. Macrophage deactivation by interleukin-10. J Exp Med 174: 1549-1555, 1991.

25. Krump E, Lemay $G$, Borgeat $P$. Adenosine $A_{2}$ receptor-induced inhibition of leukotriene $\mathrm{B}_{4}$ synthesis in whole blood ex vivo. Br J Pham macol 117: 1639-1644, 1996.

26. Tanabe $M$, Terashita $Z$, Nishikawa $K$, Hirata $M$. Inhibition of coronary circulatory failure and thromboxane $\mathrm{A}_{2}$ release during coronary occlusion and reperfusion. $I$ Cardiovasc Pharmacol 6: 442-448, 1984.

27. Lappin $D$, Whaley $\mathrm{K}$. Adenosine $\mathrm{A}_{2}$ receptors on human monocytes modulate $\mathrm{C}_{3}$ production. Clin Exp Immunol 57: 454-460, 1984.

28. Jurgensen $\mathrm{CH}$, Huber BE, Zimmerman TP', Wolberg G. 3-Deazaadenosine inhibits leukocyte adhesion and ICAM-1 biosynthesis in tumor necrosis factoi-stimulated human endothelial cells. J Immunol 144: 653-661, 1990.

29. Nolte D, Lorenzen A, Lehr H-A, Zimmer F-J, Klotz K-N, Messmer K. Reduction of postischemic leukocyte-endothelium interaction by adenosine via $\mathrm{A}_{2}$ receptor. NawnynSchmiedeberg's Arch Pharmacol 346: 234-237, 1992.

30. Bullough DA, Magill MJ, Mullane KM, Firestein GS. Carbohydrate- and CD18dependent neutrophil adhesion to cardiac myocytes: effects of adenosine. Cardiovasc Res 32: 328-334, 1996.

31. Olafsson B, Forman MB, Puett DW, Pou A, Cates CU, Friesinger GC, Virmani R. Reduction of reperfusion injury in the canine preparation by intracoronary adenosine: importance of the endothelium and the no-reflow phenomenon. Circulation 76: 1135$1145,1987$.

32. Firestein GS, Bullough DA, Erion $M D$, Jimenez $R$, Ramirez-Weinhouse $M$, Barankiewicz J, Smith CW, Gruber HE, Mullane KM. Inhibition of neutrophil adhesion by adenosine and an adenosine kinase inhibitor. The role of selectins. $J$ lmmunol 154: 326-334, 1995.

33. Rosengren $\mathrm{S}$, Bong GW, Firestein GS. Anti-ünflammatory effects of an adenosine kinase inhibitor. Decreased neutrophil accumulation and vascular leakage. I Immunol 154: 5444-545l, 1995.

34. Cronstein BN, Naime D, Firestein GS. The anti-inflammatory effects of an adenosine kinase inhibitor are mediated by adenosine. Arthriris Rheum 38:1040-1045, 1995.

35. Sciotti VM, Van Wylen DG. Increases in interstitial adenosine and cerebral blood flow with inhibition of adenosine kinase and adenosine deaminase. I Cereb Blood Flow Metab 13: 201-207, 1993.

36. Gunther GR, Herring MB. Inhibition of neutrophil superoxide production by adenosine released from vascular endothelial cells. Ann Vasc Surg $5: 325-330,1991$.

37. Issekutz $\mathrm{AC}$, Movat HZ. The effect of vasodilator prostaglandins on polymorphonuclear leukocyte infiltration and vascular injury. Am $J$ Pathol 107: 300-309, 1982.

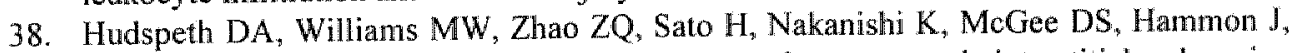
Vinten-Johansen $J$, Van Wylen DG. Pentostatin-augmented interstitial adenosine prevents postcardioplegia injury in damaged hearts. Ann Thorac Surg 58: 719-727, 1994. 
39. Zughaib ME, Abd-Elfattah AS, Jeroudi MO, Sun JZ, Sekili S, Tang XL, Bolli X. Augmentation of endogenous adenosine attenuates myocardial 'stunning' independently of coronary flow or hemodynamic effects. Circulation 88: 2359-2369, 1993.

40. Sandhu GS, Burrier $\mathrm{AC}$, Janero DR. Adenosine deaminase inhibitors attenuate ischemic injury and preserve energy balance in isolated guinea pig heart. Am I Physiol 265: H.249H1256, 1993.

41. Phillis JW, Oregan MH. Effects of an inhibitor of adenosine deaminase, deoxycoformycin, and of nucleoside transport, propentofylline, on post-ischemic recovery of adenine nucleotides in rat brain. Neurochem Res $21: 347-353,1996$.

42. Lasley RD, Mentzer RM. Protective effects of adenosine in the reversibly injured heart. Ann Thorc Surg 60: 843-846, 1995.

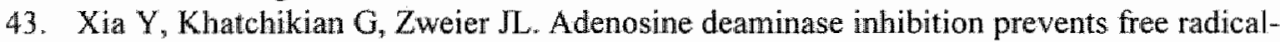
mediated injury in the postischemic heart. J Biol Chem 271: 10096-10102, 1996.

44. Koke JR. Fu LM, Sun D, Vaughan DM, Bittar N. Inhibitors of adenosine catabolism improwe recovery of dog myocardium after ischemia. Moll Cell Biochem 86: 107-113, 1989.

45. Eigler A, Greten TF, Sinha B, Haslberger C, Sullivan GW, Endres S. Endogenous adenosine curtails lipopolysaccharide-stimulated tumour necrosis factor synthesis. Scand J Immunol $45: 132-139,1997$.

46. Van Belle H. Nucleoside transport inhibition: a therapeutic approach to cardioprotection via adenosine? Cardiovasc Res 27: 68-76, 1993.

47. Mistry G, Drummond GI. Adenosine metabolism in microvessels from heart and brain. $J$ Mol Cell Cardiol 18: 13-22, 1986.

48. Galiñanes M, Qiu $Y$, Van Belle H, Hearse DJ "Metabolic and functional effects of the nucleoside transport inhibitor R75231 in the ischaemic and blood reperfused rabbit heart. Cardiovasc Res 27: 90-95, 1993.

49. Gan XHT, Cook MA, Moffat MP, Karmazyn M. Transient ischemia in the presence of an adenosine deaminase plus a nucleoside transport inhibitor confers protection against contractile depression produced by hydrogen peroxide: possible role of glycogen. $J \mathrm{Mol}$ Cell Cardiol 28:1165-1176, 1996.

50. Deckent $\mathrm{J}$, Gleiter $\mathrm{CH}$. Adenosine: an endogenous neuroprotective metabolite and neuromodulator. J Neural Tramsm Supp/ 43: 23-31, 1994.

51. Booster MH, Yin M, Maessen JG, Stubenitsky BM, Wijnen RMH, Kootstra G. Protection of canine renal grafts by renin-angiotensin inhibition through nucleoside transport blockade. Thansplant Int 8: 207-213, 1995.

52. Mullane K. Acadesine: the prototype adenosine regulating agent for reducing myocardial ischaemic injury. Cardiovasc Res 27: 43-47, 1993.

53. Mullane $K$, Bullough D, Shapiro D. From academic vision to clinical reality. A case study of acadesine. Trends Cardiowasc Med 3: 227-234, 1993.

54. Bullough DA, Zhang C, Montag A, Mullane KM, Young MA. Adenosine-mediated inhibition of platelet aggregation by acadesine. A novel antithrombotic mechanism in vitro and in vivo. J Clin Invest 94: 1524-1532, 1994.

55. Mathew JP, Rinder CS, Tracey JB, Auszura LA, O'Connor T, Davis E, Smith BR. Acadesine inhibits neutrophil CDIlb upregulation in vitro and during in vivo cardiopulmonary bypass. J Thorac Cardiovasc Surg 109: 448-456, 1995. 
56. Bullough DA, Potter S, Fox MH, Zhang C, Metzner EK, Mullane KM. Acadesine prevents oxidant-induced damage in the isolated guinea pig heart. J Pharmacol Exp Ther 266: 666-672, 1993.

57. Akkan AG. Malaisse WJ. Insulinotropic action of AICA riboside. 1. Insulin release by isolated islets and the perfused pancreas. Diabetes Res 25: 13-23, 1994.

58. Gruber HE, Hoffer ME, McAllister DR, Laikind PK, Lane TA, Schmid-Schoenbein GW, Engler RL. Increased adenosine concentration in blood from ischemic myocandium by AICA riboside. Effects on flow, gramulocytes, and injury. Circulation 80: 1400-1411. 1989.

59. Schoenberg MH, Poch B, Moch D, Marzinzig M, Manzinzig E, Matteldt T, Gruber $H_{\text {, }}$ Beger HG. Effect of acadesine treatment on post-ischemic damage to small intestine. Am J Physiol 269: H1752-H1759, 1995.

60. Fabian M, Yockey JM, Proctor KG. Acadesine and lipopolysaccharide-evoked pulmonary dysfunction after resuscitation from traumatic shock. Surgery 119: 302-315, 1996.

61. Spiers JP, Fabian TC, Kudsk KA, Proctor KG. Resuscitation of hemornagic shock with hypertonic saline/dextran or lactated Ringer's supplemented with AICA riboside. Cinc Shock 40: 29-36, 1993.

62. Asako H, Wolf RE, Granger DN. Leukocyte adherence in rat mesenteric venules: effects of adenosine and methotrexate. Gastroenterology 104: 31-37, 1993.

63. Gadangi P, Longaker M, Naime D, Levin RI, Recht PA, Montesinos MC, Buckley MT, Carlin $\mathrm{G}$, Cronstein $\mathrm{BN}$. The anti-inflammatory mechanism of sulfasalazine is related to adenosine release at inflamed sites. I Immunol 156:1937-1941, 1996.

64. Cronstein BN, Naime D, Ostad E. The antiinflammatory mechanism of methotrexate. Increased adenosine release at inflamed sites diminishes leukacyte accumulation in an in vivo model of inflammation. $/$ Clin Imest 92: 2675-2682, 1993.

65. Asako H, Kubes P, Baethge BA, Wolf RE, Granger DN. Colchicine and methotrexate reduce leukocyte adherence and emigration in rat mesenteric venules. Inflammation 16: 45-56, 1992.

66. Cronstein BN, Eberle MA, Gruber HE, Levin RI. Methotrexate inhibits neutrophil function by stimulating adenosine release from connective tissue cells. Proc Narl Acad Sci USA 88: 2441-2445, 1991 .

67. Dumn DL. Monoclonal antibodies for diagnosis and treatment. Arch Surg 128: 1274 . $1280,1993$.

68. Llewelyn MB, Hawkins RE, Russell SJ. Monoclonal antibodies in medicine. Adapting antibodies for clinical use. Br Med J 305: 1348-1352, 1992. 
CHAPTER 8

Summary / Samenvatting 


\section{SUMMARY}

In the first section of Chapter 1 , the clinical relevance and the pathophysiology of the inflammatory response to ischemia-reperfusion are outlined, emphasizing the role of the polymorphonuclear leukocyte (neutrophil) as the primary effector cell of reperfusion injury. A central pathogenetic mechanism in the development of reperfusion injury is the generation of oxygen free radicals, predominantly by the capillary endothelium, which induce the production and release of several inflammatory mediators, such as arachidonic acid metabolites, cytokines and activated complement proteins. As a result, neutrophils are attracted to the inflammatory site, become activated and adhere to the vascular endothelium, and finally transmigrate through the endothelial barrier into the target tissue. The neutrophil-endothelial adhesive interactions consist of sequential stages, each involving different types of complementary adhesion molecules, expressed on neutrophils and endothelial cells, respectively. Eventually, activated neutrophils cause tissue injury by producing oxidants and protelolytic enzymes that degrade the extracellular matrix and induce cellular injury. Thus, three pathophysiological levels of ischemia-reperfusion injury can be distinguished: the effector level (neutrophils and oxidants), the mediator level (arachidonic acid metabolites, cytokines, activated complement-proteins), and the tissue level (the vascular endothelium expressing adhesion molecules). Accordingly, we describe the therapeutic approaches to ischemia-reperfusion injury, that are aimed at interfering at either the effector, the mediator or the tissue level of inflammation.

In the second section of the introduction, the role of adenosine as a retaliatory metabolite during ischemia and reperfusion is depicted. Adenosine, a metabolite of ATP degradation during ischemia, counteracts the deleterious effects of ischemia and reperfusion on the cardiovascular system and metabolism as a result of ligation of specific celll-surface adenosine receptors. By reducing metabolic demand and adjusting cellular energy supply, adenosine "retaliates" against the external ischemic stimulus that causes its formation, and has therefore been termed a "retaliatory metabolite" by Newby. Adenosine binding to $\mathrm{A} 2$ receptors also effectively inhibits superoxide generation by activated neutrophils and reduces neutrophil adhesiveness to the endothelium, thus exerting anti-inflammatory effects. Based on the concept, originally introduced by Cronstein, that adenosine functions as an endogenous immunoregulatory negative feedback mechanism during inflammation, the main hypothesis underlying the experimental work described in this thesis, is that adenosine downregulates the inflammatory function of various different 
immunocompetent cell types that are involved in inflammatory responses, particularly during ischemia and reperfusion. Furthermore, we hypothesized that pharmacological interference in adenosine metabolism, resulting in enhanced local endogenous adenosine levels, could represent an attractive, alternative target of therapeutic intervention in inflammatory conditions, including reperfusion injury.

In Chapter 2 it is demonstrated that adenosine effectively inhibits the release of the granule proteins elastase, bactericidal/permeability-increasing protein, and defensins by TNF $\alpha$ - and LPS-stimulated neutrophils in human whole blood. Using specific adenosine receptor agonists and antagonists the involvement of A2 as well as A3 receptors in adenosine-mediated inhibition of neutrophil degranulation is evidenced, while the presence of A3 receptors in human neutrophils is demonstrated for the first time. In addition, the adenosineregulating agent GP515 is shown to attenuate degranulation via an adenosinemediated mechanism, pointing to its potential relevance to the treatment of neutrophil-mediated tissue injury.

In Chapter 3, we provide evidence that adenosine inhibits the production of TNF $\alpha$, IL- 6 and IL- 8 by LPS-activated human monocytes in vitro with a differential potency. The results obtained with the adenosine analogue 2chloroadenosine indicate that inhibition of cytokine release by adenosine is primarily an A2-mediated event, and suggest an additional 'retaliatory' action of adenosine during pathological conditions, in which cytokine production by activated mononuclear phagocytes is involved, such as sepsis and ischemiareperfusion injury.

In Chapter 4 the effects of adenosine on two major determinants of endothelial cell activation, i.e. the release of pro-inflammatory cytokines and the expression of adhesion molecules, are studied. Adenosine dose-dependently inhibits the release of IL- 6 and IL- 8 by stimulated human umbilical vein endothelial cells (HUVEC). Expression of E-selectin and VCAM-1, but not ICAM-1, by activated HUVEC is also reduced by adenosine. Inhibition of endogenous adenosine deaminase activity by EHNA or deoxycoformycin strongly enhances the inhibitory effects of exogenous adenosine on cytokine release and expression of E-selectin and VCAM-1. However, a clear role for specific adenosine-receptors in the described inhibitory events could not be established. Taken together, these data imply that the vascular endothelium constitutes an important target for the anti-inflammatory actions of adenosine. 
In Chapter 5 we use a well-controlled in vitro hypoxia-reoxygenation model, mimicking in vivo ischemia-reperfusion, to investigate in parallel the effects of hypoxia and reoxygenation on endothelial activation and adenosine release. We find that neither hypoxia nor reoxygenation for varying periods of time, induce pro-inflammatory activation of HUVEC, as determined by cell-surface expression of the adhesion molecules E-selectin, ICAM- 1 and VCAM-1, as well as by extracellular release of $[\mathrm{L}-6$ and IL-8, although HUVEC remain morphologically and functionally intact under these conditions. At the same time however, hypoxia significantly enhances the release of adenosine by HUVEC, an event that can be strongly potentiated by the adenosine kinase inhibitor GP515, suggesting that the anti-inflammatory potential of the endothelium can be enforced during hypoxia by pharmacological interference in endogenous adenosine metabolism.

In Chapter 6 the efficacy of the adenosine-regulating agent GP515 in in vivo ischemia-reperfusion is evaluated, by investigating its effects on the hepatic inflammatory and microcirculatory response to hemorrhagic shock and resuscitation in the rat. While in untreated rats subjected to hemorrhagic shock and resuscitation, firm leukocyte-sinusoidal adhesion was strongly enhanced in the periportal and midzonal sublobular regions, and sinusoidal diameters were markedly reduced, pretreatment with GP5 15 significantly attenuated shock and resuscitation-induced leukocyte adhesion in both regions, enlarged sinusoidal diameters, and tended to improve sinusoidal blood flow. These results were associated with reduced liver injury two days after shock and resuscitation. GP515 did not display systemic macrohemodynamical or hematological side effects. We hypothesize that the adenosine-regulating agent GP515 has a therapeutic potential to protect from reperfusion injury in vivo by capitalizing on the beneficial anti-inflammatory and microcirculatory actions of endogenous adenosine.

In Chapter 7 we propose that the newly discovered anti-inflammatory features of adenosine have added a new dimension to the "retaliatory metabolite" concept, as originally introduced by Newby. We have found that adenosine affects the inflammatory function of neutrophils, monocytes and endothelial cells. Based on the results from the experiments described in this thesis, as well as on data that have recently emerged from experimental studies by others, we conclude that the anti-inflammatory potential of adenosine extends to the effector, the mediator, as well as the tissue level of inflammation. "Therefore, pharmacological enhancement of endogenous adenosine levels at its 
local site of formation, could represent an attractive, alternative therapeutic strategy in various inflammatory conditions, including ischemia-reperfusion injury. Finally, several of these pharmacological approaches are discussed in relation to ischemia and reperfusion, as well as other inflammatory disorders. 


\section{SAMENVATTING}

In het eerste gedeelte van Hoofdstuk 1 worden de klinische relevantie en de pathofysiologie van de ontstekingsreaktie op ischemie-reperfusie beschreven, waarbij de rol van de polymorf nucleaire leukocyt (de neutrofiel) als primaire eflector cel in het ontstaan van reperfusieschade wordt benadrukt. Een centraal pathogenetisch mechanisme van reperfusieschade is de vorming van vrije zuurstof radicalen, overwegend door het capillair endotheel, die de productie en afgifte van verschillende ontstekingsmediatoren, zoals arachidonzuur metabolieten, cytokinen, en geactiveerde complement eiwitten induceren. Als gevolg daarvan worden neutrofielen aangetrokken naar de plaats van ontsteking en vervolgens geactiveerd, waarna ze hechten aan het endotheel van de vaatwand en tenslotte transmigreren door de endotheel barrière naar het weefsel. Adhesie van neutrofielen aan het endotheel voltrekt zich in verschillende opeenvolgende stadia, waarin steeds verschillende typen adhesiemoleculen betrokken zijn, die complementair tot expressie worden gebracht door respectievelijk neutrofielen en endotheel. Uiteindelijk veroorzaken geactiveerde neutrofielen weefselschade door de productie van oxidantia en proteolytische enzymen, die de extracellulaire matrix afbreken en celschade induceren. Er kunnen aldus drie niveaus in de pathofysiologie van ischemie-reperfusieschade worden onderscheiden: het effector niveau (vrije zuurstof radicalen en neutrofielen), het mediatoren niveau (arachidonzuur metabolieten, cytokinen, geactiveerde complement-eiwitten), en het weefsel niveau (het vasculaire endotheel dat adhesiemoleculen tot expressie brengt). We beschrijven dienovereenkomstig de therapeutische benaderingen die interfereren op het effector, het mediatoren, dan wel het weefsel niveau van de ontstekingsreaktie na ischemie-reperfusie.

In het tweede gedeelte van de inleiding wordt de rol van adenosine als "vergeldings-metaboliet" in ischemie en reperfusie beschreven. Adenosine ontstaat als afbraakprodukt van ATP tijdens ischemie, en gaat de schadelijke gevolgen van ischemie en reperfusie op het cardiovasculaire systeem en het metabolisme tegen, doordat het aan specifieke adenosine receptoren op de celmembraan bindt. Doordat het de metabole vraag reduceert en de energievoorziening van de cel corrigeert, "vergeldt" adenosine de externe ischemische stimulus die zijn vorming veroorzaakt, en is daarom door Newby een "vergeldings-metaboliet" genoemd. Door binding aan A2 receptoren remt adenosine bovendien de vorming van superoxide door geactiveerde neutrofielen en vermindert het de adhesie van neutrofielen aan endotheel, en oefent daarmee ontstekingsremmende effecten uit. Gebaseerd op het idee, oorspronkelijk 
geïntroduceerd door Cronstein, dat adenosine functioneert als een endogeen immuunregulerend negatief terugkoppelingsmechanisme tijdens ontsteking, is de belangrijkste hypothese die ten grondslag ligt aan het experimentele werk, zoals dat in dit proefschrift is beschreven, dat adenosine de inflammatoire aktiviteit van verschillende immunocompetente celtypen die betrokken zijn bij ontstekingsreakties, in het bijzonder tijdens ischemie en reperfusie, remt. Een tweede hypothese is dat farmacologische interventie in het metabolisme van adenosine, resulterend in verhoogde locale spiegels van endogeen adenosine, een aantrekkelijk alternatief doelwit van therapeutische interventie zou kunnen vormen in ontstekingsprocessen, zoals reperfusieschade.

In Hoofdstuk 2 wordt aangetoond dat adenosine op effectieve wijze de afgifte van de granule eiwitten elastase, bactericidal/permeabillity-increasing protein en defensins door TNF $\alpha$ - en LPS-gestimuleerde neutrofielen in humaan volbloed remt. Door gebruik te maken van specifieke adenosine receptor agonisten en antagonisten, wordt het bewijs geleverd voor de betrokkenheid van zowel A2 als $\mathrm{A} 3$ receptoren in de inhibitie van neutrofiel degranulatie door adenosine. Bovendien wordt voor het eerst de aanwezigheid van $\mathrm{A} 3$ receptoren op humane neutrofielen aangetoond. Verder wordt beschreven dat de adenosine-regulerende stof GP515 degranulatie remt via een adenosinegemedieerd mechanisme, hetgeen wijst op de mogelijke therapeutische relevantie van deze stof ten aanzien van weefselschade die wordt veroorzaakt door neutrofielen.

In Hoofdstuk 3 tonen we aan dat adenosine de productie van TNF $\alpha, \mathrm{IL}-6$ en LL-8 door LPS-geactiveerde humane monocyten remt met een verschillende potentie. Resultaten verkregen met het adenosine-analogon 2-chloroadenosine wijzen erop dat de remming van cytokine afgifte door adenosine vooral door A2 receptoren wordt gemedieerd, en suggereren het bestaan van een additioneel "vergeldings-effect" van adenosine tijdens situaties die worden gekenmerkt door verhoogde cytokine productie door geactiveerde mononucleaire fagocylen, zoals sepsis en ischemie-reperfusieschade.

In Hoofdstuk 4 worden de effecten van adenosine op twee determinanten van endotheelcel activatie, namelyk de afgifte van pro-inflammatoire cytokinen en de expressie van adhesiemoleculen, bestudeerd. Adenosine remt op dosisafhankelijke wijze de afgifte van IL-6 en IL-8 door gestimuleerde humane navelstrengvene endotheelcellen (HUVEC). De expressie van E-selectin en VCAM-1, maar niet van ICAM-1, door geactiveerd HUVEC wordt eveneens 
geremd door adenosine. Inhibitie van endogene adenosine deaminase activiteit door EHNA of deoxycoformycine versterkt de remmende effecten van exogeen adenosine op de afgifte van cytokinen en de expressie van E-selectin en VCAM-1 op krachtige wijze. Een duidelijke rol van specifieke adenosine receptoren in de beschreven remmende effecten van adenosine kon echter niet worden vastgesteld. Tesamen impliceren deze gegevens dat het vasculaire endotheel een belangrijk doelwit vormt van de anti-inflammatoire activiteit van adenosine.

In Hoofdstuk 5 gebruiken we een goed gecontroleerd in vitro hypoxiereoxygenatie model, waarin in vivo ischemie-reperfusie wordt nagebootst, om de effecten van hypoxie en reoxygenatie op endotheel activatie en afgifte van adenosine tegelijkertijd te kunnen onderzoeken. We stellen vast dat, hoewel HUVEC morfologisch en functioneel intact blijven onder deze omstandigheden, noch hypoxie noch reoxygenatie van verschillende tijdsduur, pro-inflammatoire activatie van HUVEC induceren, gemeten aan zowel de expressie van de adhesiemoleculen E-selectin, ICAM-1 en VCAM-1, als aan de extracellulaire afgifte van IL-6 en IL-8. Tegelijkertijd echter verhoogt hypoxie op significante wijze de afgifte van adenosine door HUVEC. De afgifte van adenosine door HUVEC tijdens hypoxie kan in hoge mate worden versterkt door de adenosine kinase remmer GP515, hetgeen suggereert dat de potentiele ontstekingsremmende activiteit van het endotheel tijdens hypoxie kan worden versterkt door farmacologisch ingrijpen in het endogene adenosine metabolisme.

In Hoofdstuk 6 wordt de effectiviteit van de adenosine-regulerende stof GP515 gedurende in vivo ischemie-reperfusie bestudeerd aan de hand van de ontstekingsreactie en de microcirculatie in de lever na hemorrhagische shock en resuscitatie in de rat. In onbehandelde ratten die werden onderworpen aan hemorrhagische shock en resuscitatie, was de adhesie van leukocyten aan de sinusoïden sterk verhoogd in de periportale en midzonale gedeelten van de leverlobuli, en waren de sinusoïdale diameters aanzienlijk gereduceerd. Behandeling met GP515 voorafgaand aan shock en resuscitatie verminderde daarentegen de leukocyten-adhesie in beide sublobulaire regio's op significante wijze, vergrootte de sinusoïdale diameters, en verbeterde de bloeddoorstroming van de sinusoïden enigszins. Deze bevindingen werden vergezeld door een afname van de leverschade twee dagen na shock en resuscitatie. Behandeling met GP515 had geen systemische hemodynamische of hematologische bijwerkingen. We formuleren de hypothese dat de adenosine-regulerende stof 
GP515 therapeutische potentie tot bescherming tegen in vivo reperfusieschade heeft, doordat het de gunstige ontstekingsremmende en microcirculatoire activiteiten van endogeen adenosine bevordert.

In Hoofdstuk 7 stellen we dat de recente nieuwe ontdekkingen van ontstekingsremmende eigenschappen van adenosine een nieuwe dimensie hebben toegevoegd aan het begrip "vergeldings-metaboliet", zoals dat oorspronkelijk door Newby werd geïntroduceerd. We hebben vastgesteld dat adenosine de inflammatoire functie van neutrofielen, monocyten en endotheelcellen beïnvloedt. Op grond van zowel de resultaten van de experimenten zoals die beschreven zijn in dit proefschrift, als de gegevens die recentelijk naar voren zijn gekomen uit experimentele studies die door anderen werden verricht, concluderen we dat adenosine remmende activiteit kan hebben op zowel het effector niveau, als het mediatoren niveau, als het weefsel niveau van ontsteking. Derhalve zou farmacologische verhoging van lokale, endogene adenosine spiegels een aantrekkelijke alternatieve strategie kunnen zijn in de behandeling van ontstekingsreacties, zoals ischemie-reperfusieschade. Tenslotte worden enkele van dergelijke farmacologische interventies in ischemie en reperfusie, en andere inflammatoire aandoeningen, besproken. 



\section{DANKWOORD}

In de allereerste plaats dank ik mijn ouders, Johannes en Rinske, die mij hebben opgevoed in een sfeer waarin warmte en geborgenheid, evenwicht en nuchterheid, en soms zelfspot en een goedaardig (vaderlijk) cynisme de boventoon voerden. Met het toenemen van de geografische afstand tussen ons werd het gevoel van onderlinge verbondenheid alleen nog maar sterker. Jullie staan mij zeer na, en daarom draag ik dit proefschrift aan jullie op.

Professor Kootstra ben ik erkentelijk voor zijn bereidheid als mijn promotor op te treden. De leden van de Beoordelingscommissie, de Professores Van Hooff, Koster, Van der Linden, Snoeckx en Struijker Boudier dank ik voor hun weiwillendheid het manuscript op kritische en constructieve wijze te beoordelen. I also express my gratitude towards Dr. Marzi for critically reviewing the manuscript.

Mijn co-promotor Dr. W.A. Buurman, beste Wim, ik beschouw het als een voorrecht een van de vele promovendi te zijn geweest, die je hebt "afgeleverd". Je bent in meer dan één opzicht een sterke persoonlijkheid, die menigmaal zowel bewondering als verwondering oproept. Wees er van verzekerd dat ik daarom, maar vooral ook dankzij je manier van begeleiding, een groot respect voor je heb. Ik besef terdege dat ik zeer veel aan je heb te danken.

Mijn co-promotor Dr. F.A.J.M. van den Wildenberg, beste Frans, ik zie je nóg voor me, tijdens mijn eerste sollicitatiegesprek, tevreden lurkend aan je pijp. Wie had toen ooit kunnen denken dat een voorgenomen basaal onderzoek naar de effecten van soft-laser zou eindigen in dit proefschrift? Wat me in jou altijd gecharmeerd heeft, is je ongebreiclelde enthousiasme, en bovenal je karakteristieke lach. Een gelijksoortig gevoel voor humor maakte dat het klikte tussen ons vanaf het eerste moment. Aan onze gezamenlijke reizen naar München (der "Haxnbauer"; Eisbein mit Sauerkraut!) en Homburg (der "FranzJosef Keller") bewaar ik dan ook mooie herinneringen. Bovendien had ik me, in wetenschappelijk én sportief opzicht, geen betere teamgenoot kunnen wensen!

Wie nu mocht denken dat het leven van een promovendus zich slechts afspeelt in prettige etablissementen in verre oorden, heeft het mis. Verreweg het grootste deel van mijn tijd bracht ik door op het Laboratorium Algemene Heelkunde, waar ik gedurende enkele jaren met veel genoegen heb gewerkt. Voor hun respectievelijke bijdrage aan de collegiale sfeer in de loop van die tijd ben ik Eckhardt von Asmuth, Marc Bemelmans, Ivo de Blaauw, Maaike Bruins, David Cobben, Cees Dejong, Marc Daemen, Mieke Dentener, Mick Deutz, Ralph 
Eijdems, Hans van Eijk, Ingeborg Engelberts, Gaby Francot, Bas Geerdes, Marcella Hallemeesch, Gabrie ten Have, Vincent Heemskerk, Trudi Jeunhomme, Laury de Jonge, Joop Konsten (dat etentje in Brussel kunnen we zeker wel vergeten?), Jet Leeuwenberg, Steven Olde Darnink, Shirley Schrijnemeeckers, Mart-Jan Rongen, Dennis Rooyakkers, Nicole Senden, Marjan Siep, Jeske Staal-Van den Brekel, Robert Kees Stad, Jessica ter Steege, Berry van Tits, Monique van der Ven, Sandra Verploegen, Anita Vreugdenhil, Carlo Welters, René Wijnen en Brigitte Willemse bijzonder dankbaar. Een speciaal woord van dank gaat uit naar Trudi Jeunhomme, die mij het isoleren en kweken van endotheel heeft geleerd, en die in een later stadium voor mij vele experimenten nauwgezet heeft uitgevoerd. Beste Trudi, toen ik begon informeerde je naar mijn culinaire vaardigheid, omdat die volgens jou te vergelijken zou zijn met de "feeling" voor het lab-werk. Dat ik nu wel eens verder kom dan het bakken van een eitje is daarom wellicht mede jouw verdienste.

Ik prijs me gelukkig met twee paranimfen die het klappen van de "promotiezweep" reeds kennen. Met beiden heb ik een speciaal gevoel van verstandhouding. Beste Marc, je was me steeds de baas tijdens het fietsen (vooral berg-opwaarts), maar op het "Bourgondische vlak" waren we, dacht ik, aardig tegen elkaar opgewassen. Ik hoop echt dat we elkaar in de toekomst toch weer wat vaker op beide terreinen zullen treffen. Beste Robert, we delen eenzelfde gevoel voor humor, en zijn behept met dezelfde gastronomische inslag. Beide zijn goede ingrediënten voor vriendschap gebleken.

Clemens Bauer and Ingo Marzi, thank you both very much for the opportunity to work with you in the experimental surgery laboratory in Homburg. I have been impressed by the accurate and thorough way in which the shock experiments were performed, as well as by the warm hospitality with which you received me at your homes on several occasions.

De vele co-assistenten, die beseften dat experimenteel wetenschappelijk onderzoek soms persoonlijke offers vraagt, en derhalve bereid waren weliswaar in ruil voor een fles kwaliteitswijn - hun bloed af te staan voor mijn experimenten, ben ik zeer dankbaar. (Dat ook mijn labgenoten en ikzelf af en toe bereid waren tot een dergelijk offer - niet eens in ruil voor een fles wijn was tekenend voor de heersende collegiale sfeer op het lab). 
Wim en Berthy Blind, mijn dankwoord zou niet volledig zijn zonder jullie daarin te betrekken. Ik vraag me soms wel eens af hoe het zonder jou, $W \mathrm{im}$, allemaal zou zijn gelopen en of dit proefschrift dan ook geschreven zou zijn. Dat je vervolgens ook nog in materiële zin een bijdrage leverde aan de publicatie ervan heb ik zeer gewaardeerd. Maar meer nog dan dat, ben ik jullie beiden dankbaar voor de vriendschap in de afgelopen jaren. Misschien komt er ooit een moment dat ik eens wat terug kan doen!

Tenslotte, lieve Jessica, aan jou heb ik mijn hart verloren. Dat ik niet af en toe ook de kluts kwijtraakte, heb ik aan jou te danken. De toekomst is van ons (wel nog even doorzetten, hè)! 



\section{List OF PUblications}

PAPERS PRESENTED IN THIS THESIS:

Bouma MG, Stad RK, Van den Wildenberg FAJM, Buurman WA.

Differential regulatory effects of adenosine on cytokine release by activated human monocytes.

Journal of Immunology 153: 4159-4168, 1994.

Bouma MG, Van den Wildenberg FAJM, Buurman WA.

Adenosine inhibits cytokine release and expression of adhesion molecules by activated human endothelial cells.

American Journal of Physiology 270 (Cell Physiology 39): C522-C529 1996.

Bouma MG, Jeunhomme TMMA, Boyle DL, Dentener MA, Voitenok NN, Van den Wildenberg FAJM, Buurman WA.

Adenosine inhibits neutrophil degranulation in activated human whole blood. Involvement of adenosine $\mathrm{A} 2$ and $\mathrm{A} 3$ receptors.

Journal of Immunology 158: 5400-5408, 1997.

Bouma MG, Van den Wildenberg FAJM, Buurman WA.

The anti-inflammatory potential of adenosine in ischemia-reperfusion injury: established and putative beneficial actions of a retaliatory metabolite.

Shock 8(5): 313-320, 1997.

Bauer C, Bouma MG, Herrmann I, Van den Wildenberg FAJM, Firestein GS, Marzi I, Buurman WA.

The adenosine kinase inhibitor GP515 attenuates leukocyte-endothelial interactions in the liver after hemorrhagic shock and resuscitation in the rat. American Journal of Physiology (Gastrointestinal and Liver Physiology): In press.

Bouma MG, Jeunhomme TMMA, De Abreu RA, Van den Wildenberg FAJM, Buurman WA.

Hypoxia/reoxygenation of cultured human endothelium: effects on cellular activation and adenosine release.

Submitted for publication.

OTHER PAPERS:

Von Asmuth EJU, Dentener MA, Bazil V, Bouma MG, Leeuwenberg JFM, Buurman WA. Anti-CD14 antibodies reduce responses of cultured human endothelial cells to endotoxin. Immunology 80: 78-83, 1993. 
Bouma MG, Buurman WA, Van den Wildenberg FAJM.

Low-energy laser irradiation fails to modulate the inflammatory function of human monocytes and endothelial cells.

Lasers in Surgery and Medicine 19(2): 207-215, 1996.

Cronstein BN, Bouma MG, Becker BF.

Purinergic mechanisms in inflammation.

Drug Development Research 39: 426-435, 1996.

Bouma MG, Maessen JG, Weerwind PW, Dentener MA, Fransen EJ, De Jong DS, Buurman WA.

Release of lipopolysaccharide toxicity-modulating proteins in patients undergoing cardiopulmonary bypass using noncoated and heparin-coated extracorporeal circuits. A clinical pilot study.

Chest I11(3): 577-583, 1997.

Dentener MA, Bouma MG, Drent M, Wouters EFM, Buurman WA.

Analysis of soluble adhesion molecule (SICAM-I and sE-selectin) levels in bronchoalveolar lavage fluid.

Submitted for publication.

\section{BOOK CHAPTERS:}

Binnendijk B, Bouma MG.

Fracturen, luxaties, en luxatiefracturen van de talus.

In: Van Mourik JB, Patka P (Eds.),

Letsels van de enkel en voet.

Symposiumcommissie Chirurgie Nederland, Haren, pp. 271-294, 1990.

Bouma MG, Laan MP, Dentener MA, Buurman WA.

Analysis of soluble adhesion molecules.

In: Johnstone AP, Turner MW (Eds.),

Immunochemistry 2: A Practical Approach.

Oxford University Press, Oxford, pp. 181-196, 1997.

Bauer C, Bouma MG, Herrmann I, Buurman WA, Marzi I.

Enhanced endogenous adenosine level attenuates the early inflammatory response in the liver following hemorrhagic shock.

In: Wisse E, Knook DL, Balabaud C (Eds.),

Cells of the Hepatic Simusoid Vol 6 .

The Kupffer Cell Foundation, Leiden, The Netherlands, pp. 229-230, 1997. 


\section{CURriculum Vitae}

Maarten Bouma werd op 21 juni 1963 geboren in Groningen. Na het behalen van het diploma Gymnasium- $\beta$ aan het Willem Lodewijk Gymnasium (19751981 ) in zijn geboortestad, startte hij er in 1981 met de studie Geneeskunde aan de Rijksuniversiteit Groningen. De wachttijd voor de co-schappen werd deels doorgebracht met het volgen van een klinische stage op de afdeling Chirurgie van het Mubarak Al-Kabeer Hospital te Koeweit. Op 26 augustus 1988 legde hij het artsexamen af. Nadien was hij gedurende enkele maanden werkzaam als ambulance-begeleider bij de Zieken Transport Maatschappij B.V. te Groningen en vervolgens van 1989 tot 1991 als assistent-geneeskundige op de afdeling Chirurgie van het Academisch Ziekenhuis Groningen (Hoofd: Prof. Dr. R. van Schilfgaarde). $\mathrm{Na}$ opnieuw enige maanden bij de ambulancedienst Z.T.M. te hebben gewerkt, was hij van juni 1991 tot maart 1995 als research-assistent Traumatologie verbonden aan de afdeling Chirurgie van het Academisch Ziekenhuis Maastricht (Hoofd: Prof. Dr. G. Kootstra) en in die hoedanigheid werkzaam op het Laboratorium Algemene Heelkunde van de Universiteit Maastricht. Daar heeft hij onder leiding van Dr. W.A. Buurman, immunoloog, en Dr. F.A.J.M. van den Wildenberg, ongevalschirurg, ondermeer het in dit proefschrift beschreven onderzoek verricht. Van 1995 tot 1996 was hij klinisch werkzaam als assistent-geneeskundige op de afdeling Chirurgie van het Academisch Ziekenhuis Maastricht. Sinds 1 december 1996 is hij in het kader van de opleiding tot orthopedisch chirurg werkzaam als arts-assistent in vooropleiding bij de Maatschap Chirurgie van het Sint Joseph Ziekenhuis te Veldhoven (Opleider: Dr. F.A.A.M. Croiset van Uchelen). Begin 1999 zal hij zijn opleiding voortzetten op de afdeling Orthopedie van het Academisch Ziekenhuis Maastricht. 